\author{
UNIVERSIDADE DE SÃO PAULO \\ ESCOLA DE COMUNICAÇÃO E ARTES \\ PROGRAMA DE PÓS-GRADUAÇÃO EM MÚSICA
}

GINA CAVALCANTE FALCÃO

Seresta e Salão: circulação, encontros e desencontros

Abordagem comparativa dos tipos de modinha na produção escrita literária e musical

São Paulo

2019 



\title{
Seresta e Salão: circulação, encontros e desencontros Abordagem comparativa dos tipos de modinha na produção escrita literária e musical
}

\author{
Versão Final
}

Dissertação apresentada à Escola de Comunicações e Artes da Universidade de São Paulo, para obtenção do título de Mestre em Música.

Área de Concentração: Processos de Criação Musical

Orientadora: Prof. $^{a}$ Dr $^{\mathrm{a}}$. Susana Cecilia Almeida Igayara de Souza

São Paulo 
Autorizo a reprodução e divulgação total ou parcial desse trabalho, por qualquer meio convencional ou eletrônico, para fins de estudo e pesquisa desde que citada a fonte. 
FALCÃO, Gina Cavalcante. Seresta e Salão: circulação, encontros e desencontros. Abordagem comparativa dos tipos de modinha na produção escrita literária e musical. 2019. 205p. Dissertação (Mestrado em Artes) - Escola de Comunicações e Artes, Universidade de São Paulo, São Paulo, 2019.

Aprovada em:

Banca Examinadora:

Prof. Dr.:

Instituição:

Julgamento:

Assinatura:

Prof. Dr.:

Instituição:

Julgamento:

Assinatura:

Prof. Dr.:

Instituição:

Julgamento:

Assinatura: 



\section{Agradecimentos}

À minha orientadora, Prof. . . Dra. Susana Igayara-Souza com admiração, respeito e gratidão por todo o apoio, interesse e precisão na condução desse trabalho.

À banca examinadora, Prof. Dra.Susana Igayara-Souza, Prof. Dr. Alberto Pacheco e Prof. Dr. Sidney Molina por aceitarem participar dessa banca.

Aos professores do programa de pós-graduação da ECA-USP, Susana Igayara-Souza, Marco Antonio da Silva Ramos, Ivan Vilela Pinto, Mário Videira, Ricardo Ballestero, Paulo de Tarso Salles e Diósnio Machado Neto, pelas contribuições nas aulas e conversas.

Aos amigos da pós-graduação Carolina de Andrade, Tiago Mayer, Max Sales e do Comunicantus pelas ricas trocas e em especial à Anne Karoline Moreira pela regência das modinhas e Felipe Silotto pela edição das partituras.

Aos pesquisadores Paulo Castagna, Ivan Vilela, Antonio Carlos dos Santos, Andrea Teixeira, Achille Pichi, Luiza Sawaya, Anna Maria Kieffer, Rubens Russomano Ricciardi , Paulo Serau, Amaury Vieira, Vanessa Weber, Marisa Ramires e Irene Sinneker pela generosidade de partilhar material e conhecimento.

Aos amigos queridos Vinícius Nogueira, Leticia Kriger, Fábio Ferreira, Adonias Calebe, Ester Freire, Tadeu Renato, Valéria Rocha, André Kaires, Valentina Maitá, Carolina Borba, Paula Del Rio, Mariana Trento, Michélle Toffoli, Teresa Longatto, Carla Pronsato, Vanessa Pereira, Lúcia Helena Silva, Mariana Ceres, Benedicto Gurgel Junior, Rodolfo Jonasson, Felipe do Val, Felipe Rodrigues e Felicia Fingermann (in memoriam) por embarcarem em ensaios, leituras e conversas sobre interpretação e projetos de modinhas.

Ao maestro Rubens Russomano Ricciardi, pela oportunidade de cantar modinhas sob sua regência com a USP- Filarmônica de Ribeirão Preto.

Ao querido professor Carmo Barbosa, pela orientação no canto.

Aos profissionais Larissa Sangrian, Luan Macedo, Maria Beatriz Falcão, João Leonardo Silveira Neto, Filipe Fonseca, Denis Abranches Jr. E Marisa de Conti pela ajuda tecnológica e revisão.

Aos queridos Ivan Vilela e Monique Mendonça, pela disponibilidade em sempre me ouvir, me acalmar e me ajudar.

À Maria Marli, por todos anos de ajuda incondicional.

Aos meus filhos Raissa Macedo e Luan Macedo, pelo estímulo, amizade e companheirismo. Aos meus pais, Marilza e Sérgio e todos os Falcões, pela compreensão com as ausências e faltas familiares nesse período. Por toda a inspiração, o suporte e o carinho dessa família que também ama a música. 

Você está fazendo um livro sobre modinhas, está vendo o trabalho que dá fazer um livro desses e anotar.

Por isso, você pode calcular com que emoção, meu filho, eu the aperto a mão e lhe bato no ombro. Com que alegria! A família não desapareceu! A estirpe de malucos (Ri) compreendeu? Não se extinguiu. Deus o abençoe!

Câmara Cascudo 



\section{RESUMO}

FALCÃO, Gina Cavalcante. Seresta e Salão: circulação, encontros e desencontros. Abordagem comparativa dos tipos de modinha na produção escrita literária e musical.. 205p. Dissertação (Mestrado em Artes) - Escola de Comunicações e Artes, Universidade de São Paulo, São Paulo, 2019.

Os objetivos gerais do trabalho são analisar a circulação e a influência recíproca entre a modinha praticada no salão e na rua e refletir sobre questões envolvidas nas práticas interpretativas, partindo de estudos anteriores: (ANDRADE, 1980); (ARAUJO, 1963); (SIQUEIRA, 1979); (VEIGA,1997); (MORAIS 2000); (ULHÔA 2007). Para tanto, foi necessário identificar e descrever as características de cada tipo de modinha, os seus meios de expressão e as possibilidades interpretativas levando em consideração o contexto em que foram produzidas. Foram elaboradas duas tabelas, uma com o inventário de coletâneas, álbuns e cadernos de modinhas e outra com uma lista de modinhas. Essa etapa de pesquisa exploratória das obras que estavam nas 37 coletâneas teve como resultado uma tabela de 3090 títulos que foi transformada em base de dados. A partir da seleção de algumas obras, foi possível observar as diferenças e os traços em comum entre a modinha praticada nos salões, por músicos que dominavam a escrita e a leitura musical, e a modinha praticada na rua, nas serestas, em geral, por músicos que tocavam de ouvido. Para apontar a identificação das modinhas foram observadas as práticas de imitação, assimilação e inovação a partir de uma análise comparativa (FERRETTI, 2013); (CHARTIER, 2002). Foram utilizados na nossa pesquisa a produção escrita sobre o gênero, os arquivos de áudio bem como documentos manuscritos de arquivos históricos, documentos oficiais e periódicos.

Palavras-chave: Modinha; Cultura Escrita; Cultural Oral; Música Brasileira. 



\begin{abstract}
FALCÃO, Gina Cavalcante. Serenade and Salon: circulation, matches and mismatches. Comparative approach of the types of 'modinha' in the literary and musical written production. 2019. 205 p. Dissertation (Master of Arts) - School of Communication and Arts, University of São Paulo, ECA-USP.
\end{abstract}

The general aims of this paper are analysing the circulation and reciprocal influence between the Brazilian musical genre 'modinha' practiced in the salons and in the streets, as well as reflecting on issues involved in interpretive practices, starting from previous studies such as (ANDRADE, 1980); (ARAUJO, 1963); (SIQUEIRA, 1979); (VEIGA, 1997); (MORAIS 2000); (ULHÔA 2007). To this end, it was necessary to identify and describe the characteristics of each type of 'modinha', its means of expression and interpretive possibilities considering the context in which they were produced. Two tables were prepared, one with the inventory of collections, albums and notebooks of 'modinhas' and another with a list of them. This exploratory research stage of the works in 37 collections resulted in a table of 3090 titles that were transformed into a database. From the selection of some works, it was possible to observe the differences and common traits between the 'modinha' practiced in the salons, by musicians who mastered reading and writing sheet music, and the 'modinha' practiced in the street, in serenades, in general by musicians who played by ear. In order to identify the 'modinhas', the practices of imitation, assimilation and innovation have been observed from a comparative analysis (FERRETTI, 2013); (CHARTIER, 2002). We have used in this research sheet production on the genre and audio files, as well as handwritten documents from historical archives, official and periodical documents.

Keywords:Modinha, written culture, oral culture, Brazilian music 



\section{SUMÁRIO}

LISTA DE FIGURAS.............................................................................................................. 17

LISTA DE ILUSTRAÇÕES .................................................................................. 20

LISTA DE TABELAS ....................................................................................... 22

LISTA DE GRÁFICOS................................................................................................... 24

INTRODUÇÃO ....................................................................................................................... 26

1 - A MODINHA _......................................................................................................... 28

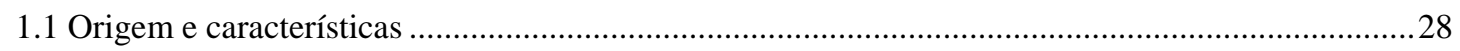

1.2 Tabela de publicações e seus usos.......................................................................................

2 - SALÃO E SERESTA......................................................................................... 56

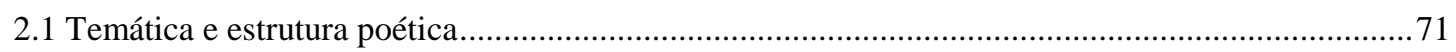

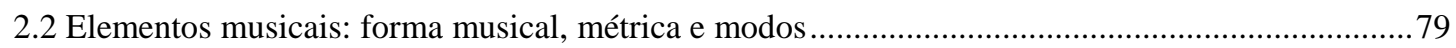

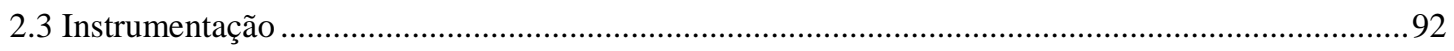

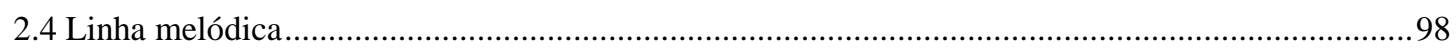

3 - CIRCULAÇÃO....................................................................................................... 104

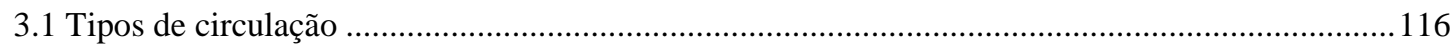

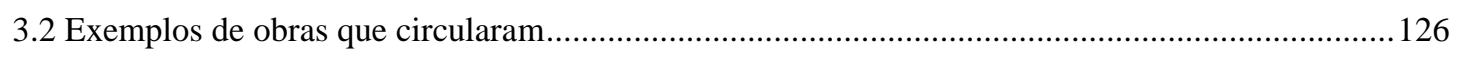

3.3 Questões interpretativas relacionadas à vocalidade na circulação do salão para a seresta...............165

3.4 Questões interpretativas relacionadas à vocalidade na circulação da seresta para o salão ..............179

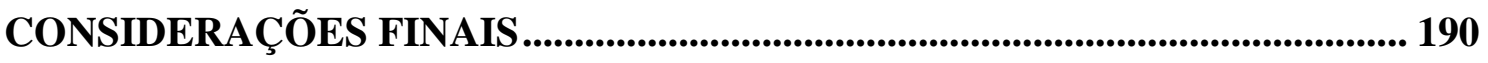

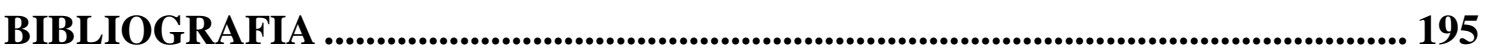

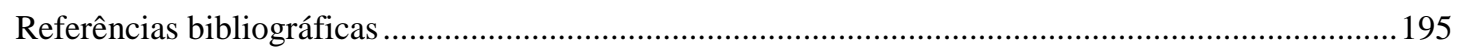

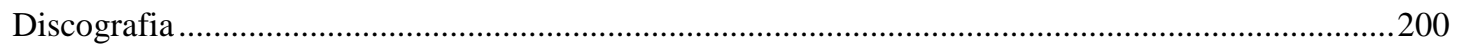

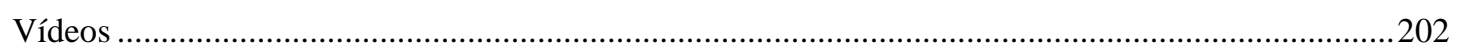

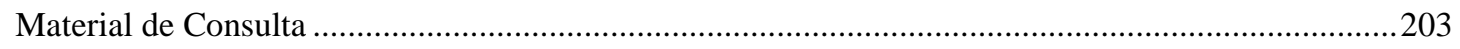

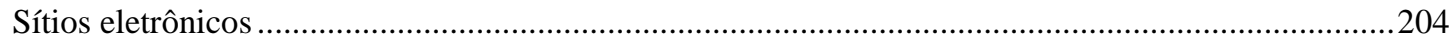

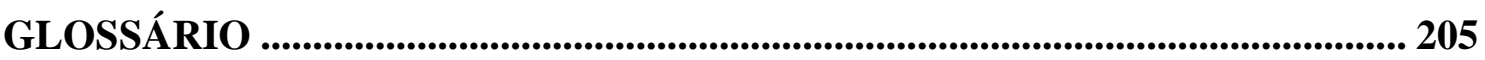





\section{LISTA DE FIGURAS}

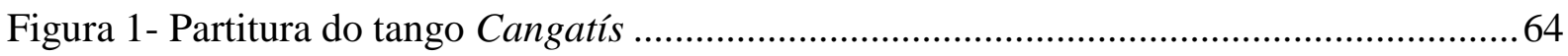

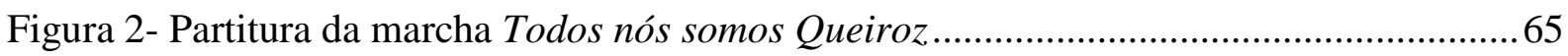

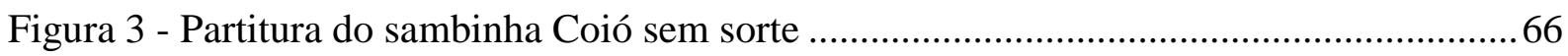

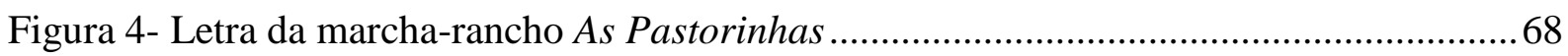

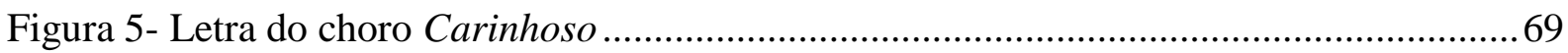

Figura 6- Primeira página da partitura da modinha Se o pranto apreciares ............................ 85

Figura 7- Segunda página da partitura da modinha Se o Pranto apreciares .............................. 86

Figura 8- Trecho inicial da modinha Último adeus de amor ................................................... 87

Figura 9- Trecho final da modinha Último adeus de amor ...................................................... 88

Figura 10- Primeira página da partitura da modinha Se o pranto apreciares ..........................90

Figura 11- Segunda página da partitura da modinha Se o pranto apreciares ..........................91

Figura 12- Trecho da modinha de seresta Soluçando te digo um triste adeus ........................ 103

Figura 13- Trecho da modinha de salão Meu coração vivia izento .........................................103

Figura 14- Partitura da modinha Marilia Bella ................................................................. 118

Figura 15- Trecho da letra da música Ao Luar ................................................................. 121

Figura 16- Primeira página da bibliografia do livro Modinhas Antigas ................................ 121

Figura 17- Partitura da modinha Ao Luar...........................................................................129

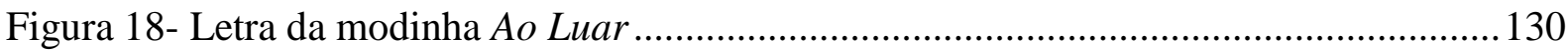

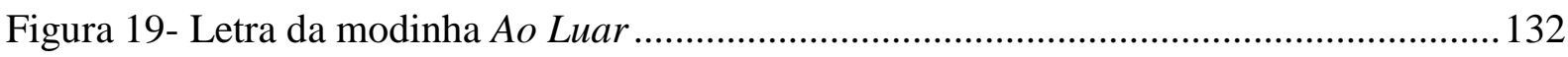

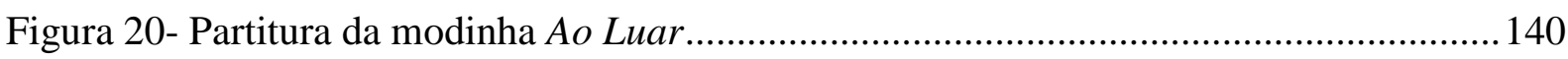

Figura 21- Partitura da modinha O poeta e a Fidalga da fonte C ........................................ 155

Figura 22- Letra da modinha O poeta e a Fidalga da fonte C ............................................156

Figura 23- Letra da modinha O poeta e a Fidalga da fonte C ............................................ 157

Figura 24- Partitura da modinha $O$ poeta e a Fidalga da fonte D .........................................158

Figura 25- Letra da modinha O poeta e a Fidalga da fonte E...............................................159

Figura 26- Partitura da modinha O poeta e a Fidalga da fonte E ......................................... 160

Figura 27- Partitura da modinha O poeta e a Fidalga da fonte F ......................................... 161

Figura 28- Partitura da modinha O poeta e a Fidalga da fonte G........................................ 162

Figura 29- Letra da modinha O poeta e a Fidalga da fonte G .............................................. 163

Figura 30- Primeira página da partitura de Róseas flores d'alvorada da fonte C ..................170 
Figura 31- Segunda página da partitura de Róseas flores d'alvorada da fonte C

Figura 32- Partitura da modinha Róseas flores d'alvorada da fonte D................................ 172

Figura 33- Letra de Róseas flores d'alvorada da fonte D .................................................... 173

Figura 34- Partitura de Róseas flores d'alvorada da fonte E ............................................. 174

Figura 35- Partitura da modinha Amo-te muito na fonte A.................................................... 182

Figura 36- Partitura da modinha Amo-te muito na fonte B ............................................... 183

Figura 37- $1^{\text {a }}$ página da partitura da modinha Amo-te muito, arranjo de Camargo Guarnieri

Figura $38-2^{\mathrm{a}}$ página da partitura da modinha Amo-te muito, arranjo de Camargo Guarnieri 



\section{LISTA DE ILUSTRAÇÕES}

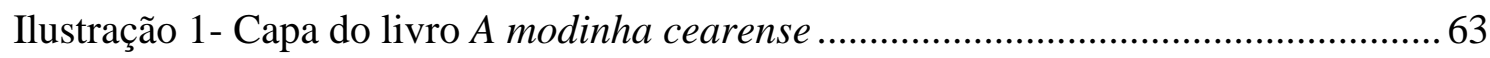

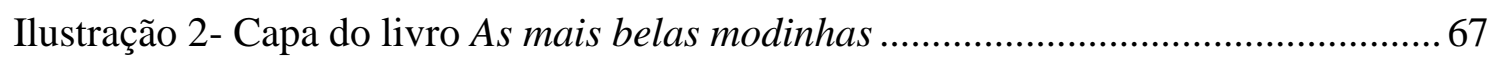

Ilustração 3- Capa do método Nova Arte de Viola ..................................................... 117

Ilustração 4- Capa do livro As Modinhas do Brasil ......................................................... 119

Ilustração 5- Capa do livro Modinhas Antigas ............................................................... 120

Ilustração 6- Capa do livro Modinhas do Passado ........................................................... 128

Ilustração 7- Capa do livro As mais belas modinhas II .............................................. 131

Ilustração 8- Capa do livro Cancioneiro popular de modinhas brasileiras .................. 134 



\section{LISTA DE TABELAS}

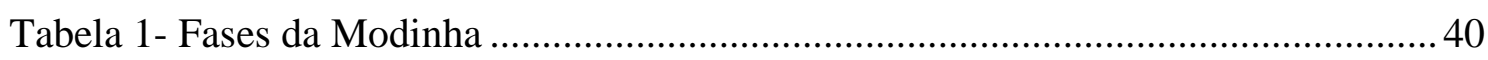

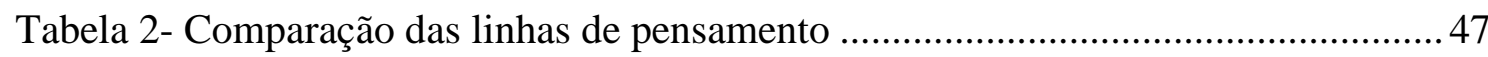

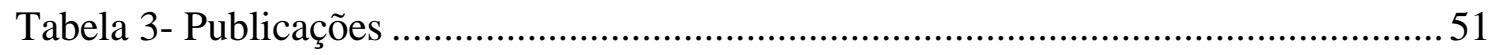

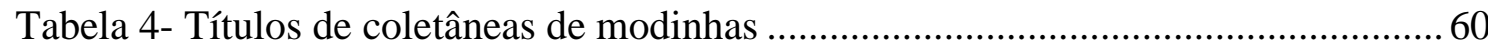

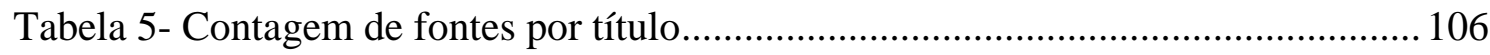

Tabela 6- Processos de circulação ................................................................................ 115

Tabela 7- Informações da música As bahianas ......................................................... 122

Tabela 8- Ordem cronológica das fontes da música As bahianas................................. 122

Tabela 9- Exemplos de obras que estão presentes em diversas fontes .......................... 126

Tabela 10- Informações da modinha Ao Luar ............................................................. 127

Tabela 11- Ordem cronológica das fontes da modinha Ao Luar .................................. 133

Tabela 12- Letras da modinha Ao Luar nas fontes A,B e D......................................... 135

Tabela 13- Letras da modinha Ao Luar nas fontes C,E e F ....................................... 137

Tabela 14- Compassos 4 e 5 da modinha Ao Luar na fonte $C$..................................... 141

Tabela 15- Compassos 4 e 5 da modinha Ao Luar na fonte F.................................... 142

Tabela 16- Compassos 4 e 5 da modinha Ao Luar na fonte E...................................... 143

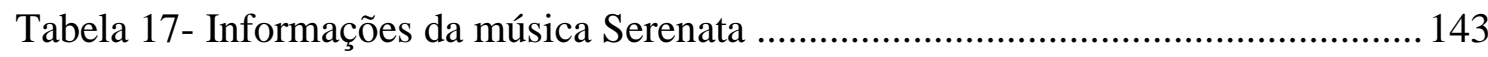

Tabela 18- Informações da música O Poeta e a Fidalga ............................................... 144

Tabela 19 - Ordem cronológica das fontes da modinha $\mathrm{O}$ poeta e a fidalga ................ 144

Tabela 20- Letras da modinha O poeta e a Fidalga nas fontes A,B e C ....................... 145

Tabela 21- Letras da modinha O poeta e a Fidalga nas fontes D,E,F e G .................... 148

Tabela 22- Contorno melódico de O poeta e a Fidalga dos compassos 1 ao 4 .............. 163

Tabela 23- Contorno melódico de O poeta e a Fidalga dos compassos 5 ao 8............. 163

Tabela 24-Contorno melódico de O poeta e a Fidalga dos compassos 9 ao 12 ............. 164

Tabela 25- Contorno melódico de O poeta e a Fidalga dos compassos 13 ao 16......... 164

Tabela 26- Contorno melódico de O poeta e a Fidalga dos compassos 17 ao 20.......... 164

Tabela 27- Contorno melódico de O poeta e a Fidalga dos compassos 21 ao 24 ......... 164

Tabela 28- Contorno melódico de O poeta e a Fidalga dos compassos 25 ao 28 .......... 165

Tabela 29- Contorno melódico de O poeta e a Fidalga dos compassos 29 ao 32 ......... 165

Tabela 30- Informações da modinha considerada de salão Róseas flores d'alvorada... 166

Tabela 31- Ordem cronológica das fontes da modinha Róseas flores d'alvorada.......... 166 
Tabela 32- Letras da modinha Róseas flores d'alvorada nas fontes A,B e C

Tabela 33- Tabela 32- Letras da modinha Róseas flores d'alvorada nas fontes D e E. 168

Tabela 34- Contorno melódico de Róseas flores d'alvorada dos compassos 1 ao 8 ( $1^{\circ}$ tempo) 175

Tabela 35-Contorno melódico de Róseas flores d'alvorada dos compassos 8 (final) ao175

Tabela 36- Contorno melódico de Róseas flores d'alvorada dos compassos 17 ao 24. 175

Tabela 37- Lista de gravações da modinha Róseas flores d'alvorada............................ 176

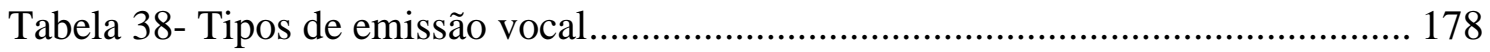

Tabela 39- Informações sobre a modinha Amo-te muito ............................................ 180

Tabela 40- Ordem cronológica das fontes da modinha Amo-te muito.......................... 180

Tabela 41- Letras da modinha Amo-te muito nas fontes A e B ................................. 180

Tabela 42- Contorno melódico de Amo-te muito- primeiro trecho nas fontes A e B .. 184

Tabela 43- Contorno melódico de Amo-te muito- segundo trecho nas fontes A e B... 184

Tabela 44 - Lista de gravações da modinha Amo-te muito ............................................ 184

Tabela 45- Contorno melódico de Amo-te muito na fonte C ..................................... 186

Tabela 46- Contorno melódico de Amo-te muito- primeiro trecho nas fontes B e C .. 186

Tabela 47- Contorno melódico de Amo-te muito-segundo trecho nas fontes B e C.... 187 


\section{LISTA DE GRÁFICOS}

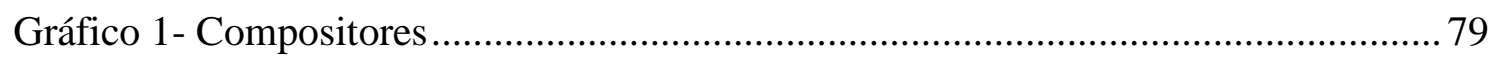

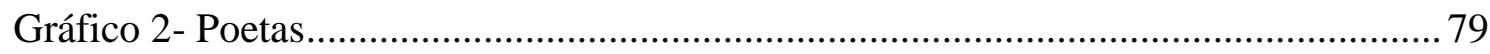

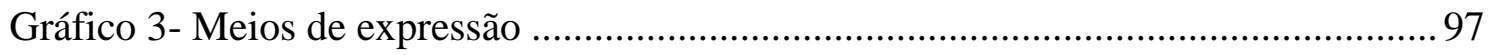

Gráfico 4- Meios de expressão por coletânea ................................................................... 102 



\section{INTRODUÇÃO}

Um fato acompanha toda e qualquer pesquisa na área das práticas interpretativas: ela inevitavelmente produzirá conhecimento que, em algum momento, auxiliará o performer em sua práxis, seja ela tocar ou ensinar alguém a tocar (BARRENECHEA, 2003, p.114).

A bibliografia de música no Brasil contou com a colaboração de escritores de outros campos, o que acabou por lhe conferir um caráter informal (BLOMBERG,2016). Mozart de Araújo, ciente desta característica, destaca que as publicações sobre a modinha eram inexistentes até 1930. Segundo ele, tudo o que foi escrito até essa data eram "interpretações líricas" (grifo nosso) e não poderiam ser consideradas investigações musicológicas (ARAUJO,1963).

Desde o século XIX até publicações mais recentes, muitos estudiosos se debruçaram sobre o tema levantando questões sobre a origem, os tipos, a natureza e o caráter da modinha e se ela poderia ser considerada gênero ou forma. Optamos por um levantamento bibliográfico por meio da leitura de autores como (ANDRADE, 1980); (BRAGA, 1877); (ARAUJO, 1963); (ROMERO, 1881); (SIQUEIRA, 1956); (VEIGA, 1998); (CASTAGNA, 2003) dentre outros, buscando apontar a falta de unidade nos discursos, definições e características das modinhas.

A dificuldade de acesso ao material escrito no final do século XVIII e início do século XIX, bem como o restrito contato com alguns trabalhos de iniciativa regional do século XX nos motivou à busca por catálogos, listas, manuscritos e edições autônomas. A falta de organização, catalogação e acesso ao material musical no Brasil foi percebida por muitos pesquisadores e, muitas vezes, é necessário incluir na pesquisa uma etapa de organização de material.

As lacunas bibliográficas e a ausência de um trabalho sistemático sobre a produção editorial de assuntos musicais faz com que seja difícil até mesmo um inventário das obras publicadas, uma das razões que fizeram com que nos decidíssemos por esse caminho, como um dos objetivos da pesquisa. (IGAYARA-SOUZA,2001, p.38).

Essa restrição relatada por Igayara-Souza, também foi percebida na busca da produção editorial dos álbuns de modinhas. Como pesquisar a circulação, se não era possível ter acesso às obras em cada coletânea? Para fazer o levantamento seria preciso olhar coletânea por coletânea cada vez que se buscasse uma obra. Optamos, então, por fazer um inventário desse material como uma das etapas do trabalho que desenvolvemos. Foram construídas duas 
tabelas, uma com o inventário de coletâneas, álbuns e cadernos de modinhas e outra com uma lista de modinhas. A primeira teria o intuito de organizar o objeto de estudo apontando a coletânea em que está inserida; e a segunda listar nas modinhas o compositor, o poeta o primeiro verso da música. Tudo isso para se investigar a circulação das obras.

Quando iniciamos a pesquisa, a pergunta principal que nos rondava era buscar quais semelhanças e quais diferenças existiam entre a modinha praticada no salão e na seresta. Porém, para analisar essa circulação e as questões que a envolvem, quer sejam musicais, sociais ou culturais, esbarramos na definição de modinha.

A modinha foi nosso tema de estudo e pesquisa no Trabalho de Conclusão de Curso, Modinhas que não querem calar, em 2015, sob orientação do Prof. Dr. Ivan Vilela e desde então o interesse pelo tema foi crescente.

Com acesso a muitos estudos sobre modinha, entre livros e artigos e a catalogação de 3090 obras integrantes em 37 coletâneas, levantamos a questão: o que dentro do repertório poderia ser considerado modinha para que essa circulação pudesse ser observada? Fez-se, então, necessária uma revisão bibliográfica sobre a modinha, uma vez que informações sobre sua origem e suas características poderiam contribuir para a reflexão sobre a circulação e as práticas interpretativas. Além desses tópicos elencados, inserimos no primeiro capítulo uma tabela de publicações e seus usos e também o endereço para acesso à base de dados de uma lista de modinhas e seus usos.

No segundo capítulo, buscamos relacionar as informações presentes nos relatos dos viajantes e nas pesquisas já elaboradas sobre o cenário musical, criando um panorama de cada época. Ainda neste capítulo observamos e refletimos sobre as características das modinhas como sua a temática, a estrutura poética, os elementos musicais, a forma, a tonalidade, a instrumentação e a linha melódica.

No terceiro capítulo, discutimos sobre os processos de circulação das obras nas coletâneas, observando essa movimentação no espaço e no tempo. Comparamos os textos e as linhas melódicas em diferentes fontes e, de certa forma, apontamos alguns critérios de classificação das modinhas de salão e de seresta. Foi necessário criar um método de comparação das linhas melódicas por graus (alturas musicais) delineando o contorno melódico de cada versão estudada. Em seguida, ouvimos gravações de modinhas feitas por diferentes intérpretes e relacionamos a análise que fizemos de cada uma dessas com o que havíamos refletido sobre a circulação do material escrito, presente nas coletâneas. Ao início da pesquisa, não esperávamos uma variedade tão grande de gravações das modinhas, o que sem dúvida, foi enriquecedor e encantador de ser apreciado. 


\section{1 - A MODINHA}

No presente capítulo busca-se uma aproximação do contexto histórico da modinha, e as suas características por meio da revisão bibliográfica. Nesse levantamento não seguiremos uma linha cronológica dos estudos da modinha. Observando que a modinha já se mostrou ubíqua e híbrida desde o seu surgimento, sobretudo por ser fruto de misturas, buscamos as primeiras definições cunhadas no século XIX para compreender os questionamentos levantados no início do século XX, a partir de 1930, e as reflexões dos musicólogos contemporâneos que atualmente escrevem sobre modinhas. Utilizamos os usos e sentidos do conceito de sincretismo proposto por Ferretti para analisar a reflexão sobre a origem e as características da modinha feitas por musicólogos, historiadores, literatos. Para Ferretti “O sincretismo ocorre na religião, na filosofia, na ciência, na arte, e pode ser de tipos muito diversificados" (FERRETTI,2013, p.99).

Partindo de um caso zero e hipotético de não-sincretismo, teremos então: 0-Separação, não-sincretismo (hipotético)

1-Mistura, junção ou fusão

2-Paralelismo ou justaposição

3-Convergência ou adaptação (FERRETTI, 2013.p. 100).

Em seguida é apresentado um inventário dos cancioneiros, álbuns e coletâneas de modinhas por ordem cronológica de publicação e uma lista de modinhas, observando os seus usos.

\subsection{Origem e características}

Desde o século XIX, a origem da modinha vem sendo tema de muitos embates entre literatos, historiadores, folcloristas, musicólogos e parece não existir consenso. Não é possível precisar se a modinha veio da ária de ópera italiana, do mote e da serranilha; se é de procedência portuguesa ou se nasceu aqui em terras brasileiras. $O$ fato é que ela surge concomitantemente às canções populares de outros países da Europa como a ballad na Inglaterra, a ariète na França, a canzonetta na Itália e a seguidilla na Espanha (NERY, 2000 apud MORAIS, 2000).

A modinha foi inserida em obras de literatura, descrita em verbetes de dicionários e enciclopédias, bem como em trechos de obras sobre história da música. Espasiani, em recente dissertação, observa que uma parte dos estudos sobre a modinha busca na origem da palavra 
um meio para desvendar a origem do gênero musical (ESPASIANI,2016).

No Diccionário Musical por Ernesto Vieira, publicado em Lisboa em 1899, o verbete modinha vem descrito como "aria, espécie de romança portuguesa muito em voga durante os fins do século passado e primeira metade do actual”. Destaca também o caráter triste e sentimental da melodia, e a recorrência do modo menor. Declara que a modinha foi de Portugal para o Brasil e que até o momento ainda não tinha sido abandonada em terras brasileiras, ao contrário tinha se tornado mais característica por seus "requebros languidos"1 com que as brasileiras a cantavam (VIEIRA, 1899, p.350).

O Diccionário Musical de Isaac Newton, em Alagoas, em 1904, apresenta o seguinte verbete: "Modinha. Diminutivo de cantiga. Poesia lírica (sic) posta em música; pequenas composições que andam em voga, e que qualquer curioso as pode criar e compor"² (NEWTON,1904, apud VEIGA,1997, p.25).

Oneyda Alvarenga a descreve como gênero de canção amorosa e sentimental. Flausino Vale compara a importância da modinha para os brasileiros assim como a ária está para os italianos, a canção para os franceses, o lied para os alemães, a saga para os escandinavos e a raga para os hindus (ALVARENGA, 1960); (VALE, 1978). ${ }^{3}$

$\mathrm{Na}$ documentação existente, a modinha é citada em cartas, depoimentos e relatos de viajantes que, em terras brasileiras, vinham com outros objetivos, distintos das pesquisas musicais ou folclóricas. Esses registros, embora não elucidem todas as dúvidas quanto à prática musical da época, indicam que a modinha esteve presente tanto no Brasil quanto em Portugal, em salões e em ambientes rurais, o que dificulta atestar onde e em qual estrato social ela realmente surgiu.

Segundo Mozart de Araújo, até o início do século XX a bibliografia sobre modinhas era escassa, o que dificultava a investigação sobre o assunto. Para Araújo, a modinha era tratada somente como tema literário (grifo nosso). A musicologia no Brasil, inicialmente, desenvolveu-se de maneira informal ${ }^{4}$. Intelectuais dos mais variados campos contribuíram com seus trabalhos (ARAUJO,1963); (BLOMBERG, 2011).

Convém ressaltar que a obra de Guilherme de Mello não consta na bibliografia dos livros de Mário de Andrade publicado em 1930 e nem de Mozart de Araújo publicado em

\footnotetext{
${ }^{1}$ Trinado, ou seja, ornamento musical que alterna rapidamente duas notas adjacentes.

${ }^{2}$ Academia Brasil-Europa de Ciência da Cultura e Institutos Integrados de Pesquisa. Disponível em: http://www.revista.akademie-brasil-europa.org/CM09-02.htm. Acesso em 20 set. 2015.

${ }^{3}$ A afirmação de Flausino provavelmente se refere ao grau de proximidade com a cultura porque se for observar a forma, pode-se dizer que a saga estaria fora desse contexto. Seu correlato no Brasil seria o romance e a moda de viola que são narrativos.

${ }^{4}$ Informal para Blomberg, quer dizer que se desenvolveu por meio da escrita de profissionais dos mais diversos campos. A musicologia não estava posicionada nas Universidades.
} 
1963. Mello foi mestre de banda, bibliotecário e interessado por aspectos ligados à musicologia. Surge aí uma questão: Por que Mário de Andrade e Mozart de Araújo teriam desconsiderado as informações contidas na obra de Mello? Eles desconheciam ou desprezaram?

Embora Manuel da Veiga, musicólogo proveniente da Bahia, que será estudado posteriormente, considere a obra de Mello como amadora e provinciana, ele destaca o esforço do autor para produzi-la longe do circuito Rio-São Paulo e considera que a musicologia da Bahia se inicia com Guilherme de Mello.

Segundo a documentação colhida por Araújo, a primeira referência literária que se conhece sobre a modinha foi feita por Nicoláo Tolentino de Almeida em 1779. O poeta português nunca veio ao Brasil. Ele cita que a vulgar modinha era cantada nos salões e destaca a característica das modinhas brasileiras por serem cantadas em segundas e primeiras (ARAUJO, 1963). Manuel da Veiga observa que segundas e primeiras poderiam ser entendidas como designações de pares de cordas, referindo-se a acompanhamentos em terças (VEIGA, 1998). Frederico de Freitas, musicólogo português, acredita que o termo "segunda" se refere à voz. Baseia-se numa notícia publicada em um almanaque popular, de 1817, chamado Almocreve das Petas, que descrevia um momento musical em que a cantora cantava modinhas sem segunda, "Só Armida e mais ninguém” (FREITAS, 1974, p.7).

Mário de Andrade, em 1930, escreveu no prefácio da edição Modinhas Imperiais que quando se trata da origem das modinhas, os portugueses dizem-na portuguesa e os brasileiros querem-na brasileira. Será que é possível perceber o que está em disputa quando alguns admitem que a modinha é portuguesa e outros que a modinha é brasileira?

Em 1877, foi publicado, em Lisboa, o livro Parnaso Portuguez Moderno de Teófilo Braga. Nessa obra, o autor, que já havia escrito livros sobre a literatura portuguesa a partir do século XII, concentrou-se na produção de sua época. Utilizou o que chamou de divisão por disposição étnica, ou seja, líricos portugueses, brasileiros e galegos. No capítulo referente à poesia brasileira Braga destaca que a poesia lírica brasileira é superior em veemência sentimental, em originalidade e em novidade de formas. Contudo, observa que existe um fenômeno de regressão, uma vez que utilizam tipos estróficos, conservados por antigos colonos portugueses, que caíram em desuso em Portugal. Para Braga, enquanto o Brasil estava sendo povoado, era possível encontrar em Portugal, fragmento da serranilha galleziana nos versos de Christovam Falcão, Gil Vicente, Sá de Miranda e Camões.

Braga que havia pesquisado a literatura portuguesa clássica e a popular, ao buscar compreender a literatura contemporânea portuguesa, a brasileira e a galega, leu os versos de 
poetas brasileiros como Álvares de Azevedo e Casemiro de Abreu, analisou e emitiu a sua opinião sobre a origem da modinha.

Foi este typo lyrico, decahido na metrópole pela imitação castelhana do século XV, e pela imitação italiana do século XVI, que reapareceu nos costumes coloniaes, adquirindo importancia litteraria, a ponto de vir a apoderar-se de novo, sob a fórma brasileira da Modinha, do gosto da corte e da sociedade portuguesa (BRAGA, 1877,p.xx).

Teófilo Braga acredita que a modinha brasileira é uma justaposição ${ }^{5}$ do tipo lírico antigo que foi usado em Portugal.

Mozart de Araújo, que será estudado posteriormente, critica o posicionamento de Braga, que considera os turanos como os introdutores da poesia lírica na Europa ocidental e meridional, sendo esse lirismo condensado na serranilha galesiana da qual a modinha seria originária. Para Araújo, essa afirmação peca pela generalização.

Em 1888, Silvio Romero escreveu a História da Literatura Brasileira, obra que conta com muitas reedições. Nessa obra o autor contrapõe a análise feita por Teófilo Braga e outros literatos e sinaliza que eles confundem a poesia popular brasileira com modinhas. Explica que as modinhas podem ser de duas espécies: a primeira é constituída de lundus e canções de autoria de poetastros e a outra de produções dos melhores líricos como Gonçalves Dias, Álvares de Azevedo, as quais foram musicadas.

Sobre as modinhas que classificou na primeira espécie, o autor alega que são obras híbridas, tentativas de imitação das criações populares. Afirma que não podem nem ser consideradas obras literárias e que constituem um gênero secundário próprio dos Catullos Cearenses de todos os tempos. Combate a ideia de que a modinha seja um produto do povo.

Não é raro ler coisas assim: "A modinha é a mais rica das formas por que se manifesta a inspiração poética de nosso povo."

É isto inexato. A modinha nem é a forma mais rica do nosso lirismo popular, nem é a forma mais perfeita de nosso lirismo culto.

A forma mais rica da poesia popular são os romances, as xácaras, as orações, os reisados, as cheganças, os versos gerais. O povo não faz, nunca fez modinhas" (ROMERO,1888, p.65).

Para Romero, o erro se dá quando a poesia bárdica popularizada é considerada genuína poesia popular. Explica que as modinhas são criações de autores conhecidos, inspirados no lirismo popular, que se espalharam sem o cuidado de manter a autoria, e por isso, a confusão.

A classificação das espécies das modinhas feita por Silvio Romero levou em conta

\footnotetext{
${ }^{5}$ Fazer menção a um tipo de relação que podem manter duas culturas.
} 
apenas a procedência do poeta. Se fosse um poeta não reconhecido, ou anônimo, a obra pertenceria a um grupo que ele considerou secundário. Se fosse uma música construída com versos de algum poeta ilustre, a modinha, segundo Romero, seria de espécie superior.

De certa forma, é controverso o posicionamento de Romero: sendo um admirador e entusiasta das criações populares, quando se refere à modinha composta por poeta do povo, essa é tratada como de menor valor. É provável que o posicionamento de desprezo fosse ideológico; isso, devido à possibilidade da ligação da modinha de verso popular com Portugal, levantada por Teófilo Braga. Romero assume um posicionamento de separação ${ }^{6}$ entre a modinha e a poesia popular.

Em seu livro Serenatas e Saraus ele declara a modinha como descendente em linha reta da melodia italiana, sendo, portanto, uma adaptação da melodia italiana (ROMERO,1902).

Para Araújo, a modinha desceu do plano aristocrático para apresentar-se no seio do povo e o lundu fez o caminho inverso subindo as escadas dos palácios (ARAUJO,1963). Em crítica a Romero, destaca que ele não percebeu o processo de interação social ficando apegado à tese de a modinha não ter origem direta das camadas do povo.

Em 1908, Guilherme de Mello escreveu o livro A música no Brasil: dos tempos coloniais até o primeiro decênio da República. A obra teve duas outras edições, uma em 1922 e outra póstuma em 1947. A segunda edição tem o texto inserido no Diccionario historico, geographico e ethnographico do Brasil e a terceira edição tem a inserção de um prefácio escrito pelo musicólogo Luiz Heitor Corrêa de Azevedo.

A obra A música no Brasil: dos tempos coloniais até o primeiro decênio da República foi escrita e impressa na Bahia e é dividida em cinco capítulos. Mello preocupa-se em buscar o que chama de "pedra fundamental da arte musical" em um país. Aborda questões sobre a raça, os povos e a constituição de nacionalidade. Para Mello, a música popular brasileira está ligada ao tripé modinha, lundu e tirana. Acredita que a fusão do sentimento musical e dos costumes dos portugueses, africanos e espanhóis com os costumes indígenas e seus cantos de guerra, de dança, religiosos, bucólicos e elegíacos resultaram nos três "tipos populares de arte musical brasileira" respectivamente. Paulo Castagna, pesquisador e professor, observa que:

Nesse livro, o autor diferencia categorias de música de acordo com sua "influência", identificando três grupos distintos: "influência indígena", "influência portuguesa, africana e espanhola" e "influência bragantina". Os dois primeiros grupos referem-se à categoria que já era denominada "música

\footnotetext{
${ }^{6}$ Não-sincretismo
} 
popular", enquanto o seguinte, chamado às vezes de música "artística", passou a ser conhecido, a partir da década de 1930, por "música erudita" (CASTAGNA,2007, p.16).

Mello acreditava que aquilo que o Brasil colonial possuía de mais belo nas artes, se devia, em muito, ao trabalho dos jesuítas. Levantou a hipótese de que as modinhas poderiam ser o fruto do legado dessa escola que trabalhou composição, harmonia e expressão. Esse legado unido ao amor, teria como resultado a modinha, uma "verdadeira inspiração artística do nosso povo" (MELLO, 1908, p.132).

$\mathrm{O}$ autor especifica que essa definição aborda a modinha clássica brasileira, aquela apreciada na "velha europa" e elogiada pelos viajantes no século XVIII; e critica as cançonetas modernas, que alega serem a decadência da música brasileira e, impropriamente, denominadas modinhas.

Em seguida, afirma que as modinhas vieram de Portugal apoiando-se nos textos de Teófilo Braga.

Estamos em pleno século XVI, justamente na época em que a canção romântica transportando-se de Portugal para o Brasil com o título de modinha nome derivado de mote ou moda, estaciona-se entre nós até os fins do século XVIII quando sob a influência das açafatas brasileiras, que constituíam a guarda de honra de D. Maria I, transportando-se de novo para Portugal torna-se o gênero de musica mais predileto nas distrações do paço (MELLO,1908, p.146).

Mello, como Braga, considera que a modinha brasileira é uma justaposição ${ }^{7}$ do tipo lírico antigo que foi usado em Portugal. Porém, utiliza do conceito de fusão para a base da música popular brasileira citando três matrizes: modinha, lundu e tirana diferentemente de seus contemporâneos que elegeram apenas duas: a modinha e o lundu.

Interessante atentar que, embora tenha feito críticas às obras de seu tempo, o autor não só colecionou muitas músicas, como exaltou figuras como Laurindo Rebelo e Xisto Bahia. A data da publicação do livro é próxima às primeiras gravações de modinhas no Brasil.

Em 1926, Vincenzo Cernicchiaro escreveu o livro Storia de la musica nel brasile: dai tempi coloniali sino ai nostri giorni (História da Música no Brasil: dos tempos coloniais até nossos dias), uma obra com mais de 600 páginas. O livro de Vincenzo é um compêndio da história da música do Brasil. Utilizamos nesse trabalho o capítulo V, Sobre a música popular por meio da influência portuguesa, espanhola, africana e holandesa

\footnotetext{
${ }^{7}$ Fazer menção a um tipo de relação que podem manter duas culturas.
} 
Cernicchiaro declara que a Bahia é o berço da modinha por acreditar que as composições dos baianos possuem espontaneidade poética, sentimento inato e fecundidade de improvisos. Classifica a modinha como uma criação popular que caracteriza o espírito do ambiente e a época em que nasceu. Cernichiaro acreditava que "cada coisa é fruto do ambiente que a circunda", por isso, liga o aparecimento da modinha ao ambiente moral do século XVII e XVIII. Para ele a arte nacional imortalizou-se nas originais danças e na melódica e suave modinha. Considerando as ideias de Cernichiaro e analisando-as sob o conceito de Ferretti seria possível que a modinha fosse resultante de mistura, fusão (CERNICHIARO,1926, p.55).

Após as publicações de grandes obras onde a modinha ocupava um capítulo, ou às vezes, um trecho de um capítulo, surgem os primeiros estudos voltados especificamente para a modinha.

Em 1930, Mário de Andrade publicou uma coletânea de quinze modinhas e um lundu, que chamou de Modinhas Imperiais. O lundu presente nessa coletânea é uma obra instrumental. Nessa coletânea o autor também incluiu um prefácio sobre a modinha. Inicia com a polêmica sobre a sua origem: se portuguesa ou brasileira. Observa que foi muito relatada nos textos dos viajantes. A modinha brasileira os encantava. Expõe alguns relatos de viajantes como Beckford ${ }^{9}$, Link $^{10}$ e Martius ${ }^{11}$. No prefácio, o autor coloca que "a proveniência erudita europeia[sic] das modinhas é incontestável”. Embora o movimento nacionalista fosse marcado pelo processo inverso, segundo suas observações, a modinha viveu no salão, nas cortes e na burguesia, somente chegando "na boca do povo do Brasil" no século XIX. Notamos que Andrade apenas levantou a hipótese de a modinha ser um caso raríssimo de uma forma erudita ter passado a popular, embora se contradiga mais adiante.

Andrade afirma que é comum que os textos das modinhas sejam anônimos ou que o autor seja um poeta menor ${ }^{12}$ e que, às vezes, os poetas bons também eram musicados. Em seguida, se contradiz dizendo que, desde os mestres da escola Mineira até fins do

\footnotetext{
8 “ $[\ldots]$ come ogni cosa è frutto dell'ambiente che la circonda [...]” Tradução feita por Vinícius Anchieta para esse trabalho.

${ }^{9}$ William Thomas Beckford, aristocrata inglês e romancista. Escreveu relatos de suas viagens para Itália, Portugal e Espanha.

${ }^{10}$ Johann Heinrich Friedrich Link, naturalista alemão visitou Portugal com o conde Johann Centurius von Hoffmannsegg , um botânico, entomólogo e ornitólogo de Dresden. Vale a observação que Tinhorão na Pequena História da Música Popular, trocou a nacionalidade de Link por francês. O erro foi repetido por Edilson Vicente de Lima na dissertação A modinha e o Lundu: dois clássicos nos trópicos.

${ }^{11}$ Carl Friedrich Philipp von Martius foi um médico, botânico, antropólogo que juntamente com Johann Baptist von Spix, viajaram pelo Brasil de 1817 à 1821 .

${ }^{12}$ Em Portugal utiliza-se "mais pequeno" para se referir a um objeto menor. O termo "menor" em Portugal possui um caráter qualitativo.
} 
Romantismo todos os poetas ilustres como Gonçalves Dias, Álvares de Azevedo e Casemiro de Abreu, tiveram seus versos musicados em modinhas. ${ }^{13} \mathrm{O}$ arcadismo possui formas clássicas de composição; porém algumas modinhas possuem o verso livre, sendo, portanto, observada por alguns autores, como uma aproximação com o Romantismo.

Mário de Andrade levantou a questão: forma ou gênero? Admitiu-a como um gênero e for fim, concluiu que o que parece manter a unidade do gênero é a poética lírica e terna e o tamanho das obras. Segundo Mário de Andrade, poderia ser essa a origem da palavra Modinha, o diminutivo de Moda, numa referência ao tamanho, por ser mais curta, e à delicadeza.

Nas entrelinhas, Mário de Andrade utilizou o conceito de adaptação quando destacou que a nossa modinha de salão se ajeitava à melódica europeia e se nacionalizava nela e apesar dela.

Em 1956, João Baptista Siqueira escreveu a primeira parte do livro Modinhas do Passado, que foi reeditado e complementado em 1979. Além do interesse histórico, folclórico e artístico, o autor declarou o seu objetivo de participar do movimento nacionalista. $\mathrm{Na}$ segunda edição a obra foi dividida em duas partes. A primeira parte Peculiaridades das Modinhas; e a segunda, com o que chamou de Primado Estético. A metodologia utilizada foi o método folclórico chamado "princípio de realização" que consiste em escolha de material em diversas fontes, recolecção e confronto de versões.

Para Baptista Siqueira a modinha "nasceu lírica e simples como a canção medieval" (SIQUEIRA,1979, p.13). Destaca que somente no século XVIII nascem as modinhas que chama de "semieruditas", ou seja, música composta com base em um texto literário, processo semelhante ao lied da Alemanha.

Acredita que elas podem ser divididas em dois tipos, modinhas de salão e modinhas de seresta. As modinhas de salão se difundiram a partir da segunda metade do século XVIII no Brasil, com partituras impressas e eram tocadas por músicos clássicos. (SIQUEIRA, 1979). As modinhas de seresta, segundo Siqueira, provavelmente aconteciam desde o século XVIII, porém a documentação é escassa, e o que se encontra com mais frequência são registros de músicas do século XIX em diante. Eram cantadas na rua sob o luar, sem uso de partitura impressa.

Siqueira divide as modinhas de acordo com sua forma: bárdica, que é monódica, ou seja, possui uma só voz condutora e é considerada a mais popular; árcade, que surgiu com os

\footnotetext{
${ }^{13}$ Mario de Andrade cita que alguns músicos se especializavam em alguns autores como fez Chiquinha Gonzaga com Casemiro de Abreu. (ANDRADE,1980, p.6)
} 
poetas da Arcádia e caracteriza-se pela instabilidade na forma e estrófica, que pode ser consideradas forma estável.

Segundo Siqueira, no início do Séc. XVI, o escritor português Gil Vicente, destaca a existência da cançoneta, da cantiga, do vilancete e do romance; e, em vários de seus autos cita a importância da arte popular monódica e sua companheira, a viola.

Baptista Siqueira considera em sua bibliografia as obras de Vincenzo Cernicchiaro, Guilherme de Mello, Flausino Vale, Renato Almeida e Mário de Andrade, porém não cita Teófilo Braga. Destaca o lirismo na arte popular do criador do teatro português, Gil Vicente, exemplificando a canção monódica cantada pelo escudeiro com escala modal. Em seguida observa que a farsa tem o título da canção proveniente do primeiro verso, tal qual ocorriam no Brasil com a modinhas mais antigas.

De certa forma, Siqueira considera que a modinha brasileira é uma justaposição ${ }^{14}$ do tipo lírico que foi usado por Gil Vicente, em Portugal.

Em 1963, Mozart de Araújo escreveu o livro A modinha e o lundu no século XVIII. Baseou-se em pesquisas feitas em 1951 e 1954 na Biblioteca de Conservatório de Paris, onde localizou o Diário de manuscritos musicais de Sigismond Neukomm. Na Biblioteca Nacional de Lisboa, por meio de microfilmes, obteve a maior parte das peças que compõem o suplemento musical do livro complementando com o material pesquisado na Biblioteca Nacional do Rio de Janeiro.

O livro consiste em duas partes: uma reflexão sobre a modinha e o lundu e uma coletânea de obras. O suplemento musical consiste em fac-símile de duas modinhas que estavam no final do Método de viola de Manoel da Paixão Ribeiro; de alguns exemplares do Jornal de Modinhas com acompanhamento de cravo pelo milhores autores dedicado a sua alteza real princesa do Brazil, impresso em Lisboa; do apêndice musical do Reise in Bresilien, recolhido por Martius, no início do século XVIII, em São Paulo, Minas e Bahia e finaliza com as doze árias do Cancioneiro de músicas populares para canto e piano recolhido e transcrito em notação moderna por Cesar das Neves, em Portugal.

Nessa obra, Mozart divide sua pesquisa entre a modinha e o lundu, e os aborda em seções separadas. Considera que a publicação de Modinhas Imperiais de Mário de Andrade é o primeiro estudo sistemático sobre a modinha. Sinaliza que a biografia da modinha, como a do lundu, está cheia de contradições e busca a autenticidade do que já foi escrito anteriormente. Faz duras críticas às publicações que não têm base documental e as que reproduzem equívocos copiados de textos anteriores.

\footnotetext{
${ }^{14}$ Fazer menção a um tipo de relação que podem manter duas culturas.
} 
Para Mozart de Araújo, "Longe de se fixar em uma forma definitiva, a modinha adquiriu, desde os seus primórdios, feição e caráter de canção acompanhada, de fundo lírico e sentimental, mas sem esquema formal definido" (ARAUJO, 1963, p.27).

O autor observa que a moda portuguesa a duo ou a solo era uma canção séria escrita por músicos que também produziam música sacra e ópera em Portugal ${ }^{15}$. Para Mozart, Domingos Caldas Barbosa, brasileiro, poeta, compositor, cantor e tocador de viola deixou o Brasil por volta de 1770 e foi o responsável pela introdução do gênero em Portugal. Alcançou popularidade cantando modinhas acompanhado de sua viola.

No final do texto expõe o que considera as características do gênero modinha: lirismo, ternura e saudade. Completa ainda com afirmações que indicam um pensamento nacionalista “Dizem que a modinha morreu. Ela não morrerá porque já não é mais uma canção, mas um estado de alma. Ela está na própria essência emotiva da nacionalidade"16(ARAUJO, 1963, p. 49).

O livro de Araújo é o mais utilizado e citado como referência bibliográfica. Autor criterioso e cuidadoso com as afirmações, sempre embasado em documentações. Nesse caso, fica o questionamento que a obra mais respeitada sobre a modinha tenha força nos documentos impressos num país onde a impressão só chegou em maior escala em 13 de maio de 1808, com a criação da Imprensa Régia.

Ao contrário do México, que já contava com uma imprensa musical em 1539, ou do Peru, que imprimiu música polifônica a quatro vozes, com texto em quíchua, em 1631, a impressão de música é fenômeno tardio no Brasil. Torna-se regular no Rio de Janeiro apenas a partir de Pierre de Laforge, por volta de 1834 (VEIGA,2004, p.1).

A tradição oral foi dominante no Brasil por séculos, em certo momento houve uma inversão e a tradição escrita passou a ser mais respeitada e todo o arcabouço oral foi desprezado. No Brasil, a primeira universidade, como um conjunto de saberes diversos, só foi criada no século $\mathrm{XX}$, enquanto nos países vizinhos, colonizados pela Espanha, as primeiras universidades datam do século XVI. A formação do povo brasileiro, portanto, está ligada ao saber oral; porém a leitura musicológica construída no Brasil, baseada na musicologia europeia, é feita a partir do referencial do saber erudito. Sem espaços de saber erudito como

\footnotetext{
${ }^{15}$ A moda a duo produziu no Brasil a moda de viola e as tiranas, no sertão baiano, que são romances cantados a duas vozes. A moda a solo recebeu o diminutivo de modinha, embora existam coletâneas de modinhas cantadas a duas vozes. Segundo Oneyda Alvarenga a tirana foi trazida da Espanha e consistia numa dança cantada. (ALVARENGA,1960, p.164).

${ }^{16}$ Idem, p.49
} 
as universidades e sem imprensa até o século XIX como utilizar o mesmo referencial europeu? Seria interessante salientar a necessidade da interação entre a musicologia histórica e a etnomusicologia nos novos estudos (VILELA, 2016).

Araújo fez extenso levantamento de relatos dos estrangeiros e se apoia neles para concluir a tese da brasilidade da modinha. Utilizou o conceito de adaptação na origem da modinha, proveniente da moda.

Em 1967, foi publicado o livro A Modinha Cearense de Edgar Ramos de Alencar conhecido como Edigar de Alencar. Na introdução, o autor faz uma pequena revisão bibliográfica. Questiona a nacionalidade da modinha, ancorado no prefácio de Mário de Andrade no livro Modinhas Imperiais. Ele destaca a presença do Arcadismo nas modinhas, observando o que já foi apontado por Baptista Siqueira em Modinhas do Passado. Levanta a hipótese se a modinha de seresta já acontecia na Bahia desde o século XVII, cantada pelo Padre Lourenço Ribeiro, baseando-se, para isso, no livro de Afonso Ruy Boêmios e Seresteiros do Passado, de 1934, sem se aprofundar no tema. Por fim, expõe a afirmação de Mozart de Araújo, A modinha e o Lundu no século VXIII, de que a modinha saiu dos salões para as ruas.

A introdução do livro é um pequeno resumo apresentando o que já tinha sido escrito sobre o tema. Observa-se que parte desse conflito perdura até a atualidade. Alencar prefere não se posicionar: lista o que já foi estudado, mas não marca uma posição. Nas entrelinhas, deixa escapar que acredita, como Mário de Andrade, ser a modinha um processo de adaptação. Na segunda parte do livro, o autor dispõe as melodias escritas, com letras separadas. Apresenta também sucinta biografia dos poetas e compositores cearenses, bem como notas sobre a música, a interpretação, o local em que foi recolhida, apresentando algumas vezes o contexto histórico-social.

Em 1977, Bruno Kiefer publicou o livro A modinha e o Lundu - duas raízes da música popular brasileira. Ele divide a obra em dois capítulos. Embora admita que a modinha e o lundu não são as únicas raízes da música popular brasileira, reconhece-as como as principais e justifica essa afirmativa apoiando-se numa concordância entre os musicólogos. Faz uma revisão bibliográfica e tece críticas sobre os trabalhos escritos anteriores, em especial alguns trechos do texto de José Ramos Tinhorão na Pequena História da Música Popular, que considera hipotéticos. Embasa-se, por meio da análise de documentos e provas, que Domingos Caldas Barbosa saiu do Brasil no final do século XVIII e inseriu a modinha brasileira em Lisboa.

O autor aponta duas interpretações possíveis para o ocorrido: 
Ou Caldas criou as suas modinhas a partir de um substrato pré-existente no Brasil (que seria desconhecido por nós) ou ele partiu de si mesmo fundindo, em suas modinhas, elementos das árias de corte portuguesas com elementos brasileiros ainda difusos e não cristalizados em gêneros musicais específicos (KIEFER,1977, p.15).

Para Kiefer, a modinha é originalmente música de salão, difundiu-se para as camadas populares com a vinda da corte portuguesa e teve ligação com as árias da corte cultivadas em Portugal no século XVIII e com a ópera italiana do século XIX. O autor, tal como Mário de Andrade, acredita que a modinha foi um processo de adaptação. Acredita também que a modinha, por seu delicado sentimento, está longe da expressividade grandiosa das árias de ópera italianas e critica a forte influência do bel canto nas interpretações.

Embora Kiefer ressalte que em toda a história da música europeia exista um fluxo e refluxo de elementos musicais entre os níveis erudito e popular, ele deixa transparecer no seu discurso um juízo de valor entre as criações quando diz que a dimensão vertical da música (harmonia) foi inventada e desenvolvida nas "altas esferas eruditas" (grifo nosso) e, depois, passou a ser utilizada na música popular.

Finaliza, observando que as modinhas, tanto populares quanto eruditas continuam sendo cultivadas no século XX. De certa forma, divide as modinhas em três tipos: eruditas, populares (com autoria) e folclóricas.

Em seu livro inseriu algumas obras seguindo o modelo da publicação de Mário de Andrade, com um texto de introdução sobre a modinha seguido de uma coletânea de obras específicas como:

Em 1984, Modinhas Luso-Brasileiras de Gerard Doderer é uma edição portuguesa. A obra é dividida em duas partes: prefácio e partituras. Após uma breve introdução sobre a modinha, Doderer disponibilizou um histórico da coletânea, indicando fontes, justificativas das escolhas e informações dos compositores. Na segunda parte do livro o autor selecionou partituras de modinhas para canto e piano.

O autor apresenta a modinha como canção sentimental e afirma que as modinhas aparecem em várias formas literárias incluindo Romance, Ária, Arietta, Lira, Hino, etc. Para Doderer, a modinha possui três fases quando se observa o aspecto musical e o seu significado músico-sociológico, como expõe a seguir: 
Tabela 1- Fases da Modinha

\begin{tabular}{|c|c|c|c|}
\hline Fase & $1^{\mathrm{a}}$ & $2^{a}$ & $3^{a}$ \\
\hline Intervalo & $\begin{array}{l}\text { Meados séc. XVIII até } \\
\text { final séc. XVIII }\end{array}$ & $\begin{array}{l}\text { Final do séc. XVIII até } \\
\text { final do séc. XIX } \\
(1860 / 1870)\end{array}$ & $\begin{array}{l}\text { Final do séc. XIX } \\
\text { até } \\
\text { início do séc. XX } \\
(1930 / 1940)\end{array}$ \\
\hline $\begin{array}{ll}\text { Local de } & \text { dencia } \\
\text { ocorrencia }\end{array}$ & Portugal & Portugal-Brasil & Brasil \\
\hline Classe & Aristocracia & Burguesia & Camada popular \\
\hline Características & $\begin{array}{l}\text { Língua nacional } \\
\text { Estilo italiano } \\
\text { Compostas por } \\
\text { mestres de grande } \\
\text { renome } \\
\text { Escrita para duetos } \\
\text { Acompanhamento de } \\
\text { viola ou cravo }\end{array}$ & $\begin{array}{l}\text { Canção de sala para uma } \\
\text { voz } \\
\text { Acompanhamento de } \\
\text { piano } \\
\text { Linha melódica mais } \\
\text { diferenciada melódica e } \\
\text { ritmicamente } \\
\text { Alteração de tempos fortes } \\
\text { Contraste maior-menor } \\
\text { Subdominante sobrepõe-se }\end{array}$ & $\begin{array}{l}\text { Amadores que } \\
\text { compõem } \\
\text { Queda de } \\
\text { qualidade } \\
\text { Canção trivial }\end{array}$ \\
\hline
\end{tabular}

Fonte: Elaborado para esse trabalho.

Observando os conceitos de Ferretti, o autor considera a modinha como uma adaptação. Para Doderer, a modinha sofreu uma transformação ao longo do tempo. Percebe-se a intenção do uso de conceitos como evolucionismo; porém, nesse caso, como foi observado por ele, houve uma queda de qualidade com o passar do tempo, e com isso ele estaria atestando o involucionismo.

O que gera esse juízo de valor e posterior crítica emitidos por Doderer? Será possível a análise comparativa classificatória sob o mesmo prisma de obras de distintas culturas, tempos e sujeitos? Será que teríamos nessa afirmação um conflito entre musicologia e etnomusicologia? Será que um gênero que atravessa três séculos e se manifesta cruzando mares pode ser analisado sob o olhar etnocêntrico? O valor de uma composição precisa estar calcado no período romântico? Caberiam muitos outros questionamentos. A origem da modinha e o posicionamento que cada autor faz, suscita reflexões mais amplas que, infelizmente não poderemos aprofundar nesse trabalho, mas, as perguntas serão campo aberto 
para próximas pesquisas.

Em 2000, Cláudio Galvão publicou A Modinha Norte-rio-grandense. A obra é dividida em três partes: prefácio, pequeno texto sobre a modinha e relação de compositores e suas obras. O prefácio é a transcrição de gravações de entrevistas com Luís da Câmara Cascudo. Nessas entrevistas, é possível perceber a dificuldade que os pesquisadores, principalmente os que estavam fora do eixo Rio-São Paulo enfrentaram para conseguir reunir material, catalogar, registrar. $\mathrm{O}$ entrevistado declara diversas vezes que não conseguiu realizar esse sonho, publicar um livro de modinhas e expõe o quão feliz está por saber que outro pesquisador estava realizando esse trabalho. Na segunda parte do livro, o autor reconhece como característica primordial da modinha a união de texto e música. Concentra-se no repertório do século XX, baseado não em reimpressões, mas em pesquisa de campo. Colheu e escreveu a maior parte das melodias presentes no livro num projeto que durou cerca de vinte anos.

Observa que a modinha tinha caráter urbano e seresteiro e que a imagem de um homem cantando sozinho abraçado ao seu "pinho" na frente da janela de sua amada é uma construção do romantismo; na maioria das vezes, as serestas eram feitas em grupo, "grupo que se diverte, chora as suas mágoas, come e bebe onde visita" (GALVÃO, 2000, p.38).

Galvão não levantou a questão da origem da modinha, porém comparou as características do gênero observadas no prefácio das Modinhas Imperiais, de Mário de Andrade, com o repertório que havia recolhido e analisado. Dispôs semelhanças como a preferência pela tonalidade menor e algumas diferenças como a ausência de apojaturas, mordentes, trilos e vocalises nas linhas melódicas, bem como a ausência de modulação na segunda parte das modinhas potiguares. Portanto, encontrou pouca semelhança entre a modinha cantada no Rio Grande do Norte e a modinha brasileira setecentista e oitocentista. Observando os conceitos de Ferretti, poderíamos dizer que o autor sugere que houve uma separação, ou seja, não-sincretismo entre a modinha de seresta e a modinha de salão.

Em 2000, foi publicado, em Lisboa, o livro Modinhas, Lunduns e Cançonetas de Manuel Morais. O livro é dividido em duas partes. A primeira, um prefácio de Ruy Vieira Nery e a segunda uma lista de partituras com contextualização e informações de cada obra.

No prefácio, Nery faz algumas considerações sobre a origem da modinha. Destaca que, na segunda metade do século XVIII, existiu um processo de desenvolvimento da canção por toda a Europa. Esse processo foi intenso na área urbana e resultou da ascensão econômica de um grupo. Esse grupo, em grande parte, proveniente do afluxo da população rural, passou a buscar atingir uma legitimação social por meio do acesso à instrução básica, que era associada 
à aristocracia. Nesse processo são incluídas a circulação de cultura literária; práticas artísticas e diversões e implantação de costumes, como prática artística doméstica, tendo como consequência a contratação de professores de dança e de música. Ele destaca que a sociedade luso-brasileira, diferentemente das outras sociedades da Europa, contava com dois outros elementos nessa composição da nova população urbana: comunidades de residentes e visitantes estrangeiros e negros libertos e escravos.

Uma crítica à essa observação de Nery é que, na verdade, poderíamos dizer que a sociedade luso-brasileira contava com mais um elemento que seria: comunidade de residentes e visitantes estrangeiros em suas cidades. Os negros libertos e os escravos não eram estrangeiros? Os estrangeiros são apenas os provenientes de outros países da Europa?

Sob o conceito de Ferretti, Nery acredita que a modinha surgiu a partir de uma fusão.

Edilson de Lima publicou em 2001 o livro As modinhas do Brasil. O livro está dividido em duas partes. Inicia com um pequeno prefácio de Regis Duprat e um estudo introdutório elaborado pelo autor com explicações sobre as transcrições; as características das modinhas; as análises harmônicas, melódicas, morfológicas, prosódicas e rítmicas; e a segunda parte contém as partituras referentes às trinta modinhas encontradas na Biblioteca da Ajuda em Lisboa.

Lima cita a polêmica acerca da origem da modinha elencando o posicionamento de alguns estudioso; porém, toma por base as pesquisas presentes no livro de Mozart de Araújo e nos artigos de Manuel da Veiga, o que será estudado posteriormente. Admite a modinha como herdeira da moda portuguesa e classifica-a como canção de fundo lírico a uma ou duas vozes. Sob o ponto de vista dos conceitos de Ferretti, admite-a como uma adaptação.

O autor destaca ainda o fato de a modinha "sair de moda" em Portugal, após a virada do século XVIII para o século XIX, enquanto que na mesma época, no Brasil, ela conquista mais espaço e resiste até o início do século XX.

Para o musicólogo Paulo Castagna, a inexistência de documentos referentes à prática de modinhas no Brasil antes do séc. XVIII, pode indicar que o manuscrito Modinhas do Brazil $^{17}$ contenha obras que se utilizem de elementos de origem brasileira, mas não necessariamente que tenham sido escritos no Brasil. Como a designação Modinha Brasileira continuou a ser usada no século XIX, poder-se-ia supor que fosse considerado uma referência ao gênero e não ao local de procedência (CASTAGNA, 2003).

A Modinha no Grão-Pará: estudos sobre ambientação e (re)criação da Modinha no

\footnotetext{
${ }^{17}$ Pesquisas realizadas por Gerard Béhague, no Mosteiro da Ajuda, em Lisboa, mostram serem brasileiras as modinhas escritas mais antigas até hoje encontradas. Possivelmente atribuídas a Domingos Caldas Barbosa.
} 
Grão-Pará de Vicente Salles foi publicado em 2005. O livro é dividido em seis partes. O autor inicia com a discussão da origem da modinha, aborda o cancioneiro nacional, trata de fenômenos urbanos e rurais, fala dos costumes mostrando um panorama social e cultural da modinha no Brasil e sua ligação com Portugal. Em seguida, aborda a modinha no contexto amazônico e insere partituras de modinhas. Os demais capítulos são de coletâneas específicas acompanhadas de contextualização e pequena biografia sobre o compositor e o poeta. $\mathrm{O}$ autor finaliza com as letras das modinhas presentes no CD.

Salles admite a descendência da modinha vinda da moda. Acredita que, no final do século XVIII, a modinha e o lundu compõem o fenômeno literário-musical mais expressivo do período e, de certa forma, poderia sinalizar que o modelo europeu de arte e literatura havia sofrido mudanças entre nós. Sob o ponto de vista conceitual de Ferretti, o autor admite uma adaptação. Embora seja unânime entre os pesquisadores que Caldas Barbosa tenha projetado a modinha nos salões aristocráticos de Lisboa, ele expõe que sempre houve quem procurasse os cantores de rua e anônimos artistas. Embora não se tenha registro, é possível que "a devolução do produto cultural" tenha acontecido também por meio de outros agentes como estudantes e marujos (SALLES, 2005, p.22).

Por fim, o autor delimita a modinha do seu objeto de estudo como "canção urbana cultivada por trovadores de mediana cultura ou erudição" tendo alcançado popularidade em todo o Brasil por largo período. Destaca o fenômeno ocorrido no Brasil de a seresta também ser muito difundida nos centros acadêmicos da faculdade de direito de São Paulo e Recife, e de medicina do Rio de Janeiro e de Salvador; e que bacharéis, enquanto estudantes, compunham modinhas e tocavam violão. Políticos e governadores das províncias eram recrutados desses bacharéis e levavam consigo o amor às modinhas, fato que ficou documentado em folhas humorísticas da época.

Manuel da Veiga, embora não tenha um livro publicado sobre modinhas, escreveu o artigo O Estudo da Modinha Brasileira em 1998. Veiga trata das reflexões e revisões sobre a modinha brasileira. Inicia o artigo com uma breve contextualização dos estudos da modinha e em seguida faz uma análise crítica do posicionamento de alguns autores como Mário de Andrade, Silvio Romero, Mozart de Araújo e Teófilo Braga. Agrupa citações de contemporâneos de Caldas Barbosa, buscando elementos para uma construção histórica da modinha. Veiga expõe dados, fatos e tece considerações sobre as conclusões dos antecessores. Considera que o termo "modinha" surgiu em Portugal no último quartel do século XVIII, muito provavelmente com diminutivo de "moda" ou derivado de "mote". Embora quando do aparecimento do termo "modinha" todos os habitantes do Brasil pudessem ser considerados 
portugueses, seria possível considerar obras criadas no Brasil como portuguesas. Alguns autores admitem o uso da nomenclatura modinhas luso-brasileiras; para Veiga, essa denominação poderia até ser admitida se usada com obras até 1815, quando o Brasil passa a ser Reino Unido; e, partir de então, os dois países caminham para cursos culturais mais independentes. Para o autor, é possível perceber diferença, até certo ponto, entre a modinha brasileira e a portuguesa e essa distinção pode ser observada na elaboração e na delineação do caráter.

Muitos autores concordam que Domingos Caldas Barbosa, brasileiro, poeta, compositor, cantor e tocador de viola deixou o Brasil por volta de 1770 e foi o responsável pela introdução do gênero em Portugal. Alcançou popularidade cantando modinhas e lundus acompanhado de sua viola (ARAUJO,1963); (KIEFER,1977); (TINHORÃO,1990); (LIMA,2001). Veiga pondera sobre a criação de um estilo musical por um indivíduo e acredita, sim, que ele tenha atuado como um divulgador.

Tendemos a crer que há uma maior homogeneidade nas culturas musicais do que é de fato a realidade. Embora sejamos injustos com os indivíduos, relutamos em reconhecer-lhes o impacto precisamente pelo fato de serem especiais. Evidentemente, para que atuem, necessitam também compartilhar algo dessa sua especificidade com os parceiros da coletividade (VEIGA,1998, p.51).

Convém pontuar que Araújo apresenta o poeta português Nicolau Tolentino de Almeida, como a primeira referência literária sobre a modinha, em 1779.

Já d'entre as verdes murteiras,

Em suavíssimos acentos

Com segundas e primeiras

Sobem as asas dos ventos

As modinhas Brasileiras (ALMEIDA apud ARAUJO, p.39).

Veiga, detentor dessa informação disponibilizada por Araújo, observa ainda que, por volta de 1775, Portugal já dispunha de imprensa para documentar a presença de Caldas nos saraus lisboetas e as atividades musicais de Portugal. No Brasil, como a imprensa oficial só veio em 1808, não dispomos de memória escrita documental para confrontar.

Edigar de Alencar, em entrevista concedida, em 1972, ao pesquisador Miguel Ângelo de Azevedo, mais conhecido como Nirez, relata a dificuldade para se conseguir documentar obras do cancioneiro popular e se elaborar um livro de modinhas. 
Foi um livro de sofrimento, foi um livro de pesquisa demoradíssima, foi um livro difícil porque eu andei coletando cadernos velhos de modinhas, rasgados, comidos por traças, reconstituindo versos que estavam perdidos e depois de tudo isso, procurando quem soubesse a música para poder juntar a melodia à letra, procurando desvendar autores, me valei de técnicos como Zé Lima Verde, saudoso Zé Lima Verde, que foi comigo várias vezes com gravador ou sem gravador para ouvir elementos como Descartes da Selva Braga e outros. Para que me dessem notícia das melodias, afim de que elas não morressem porque daqui a pouco, se tratando de composições que nunca foram gravadas e nunca foram publicadas, eles poderiam ficar perdidas definitivamente se não houvesse assim um louco, como eu, um maluco, que fosse atrás pelos cafundós, pelo mata galinha, atrás de saber quem sabia cantar a modinha tal. Fazendo senhoras de setenta anos voltarem a cantar, reclamando embora, desentoando aqui, desentoando ali, mas a verdade é que eu consegui com um trabalho hercúleo, um trabalho que eu tive que vir várias vezes à Fortaleza, em que eu gastei não só dinheiro, mas muito esforço. Foi um trabalho de sangue, suor e lágrimas (ALENCAR, 1972). ${ }^{18}$

O relato de Alencar, tão elucidativo, enumerando as dificuldades para se registrar a música popular, em tempo tão próximo, vem corroborar com a linha de pensamento de Veiga e de Vilela de que não possuímos memória escrita para confronto; e para nós, pior, pois mesmo depois da chegada da imprensa, a dificuldade para se coletar e registrar a memória oral permaneceu. Ou seja, a memória escrita produzida no Brasil não tinha intenção de abranger o registro e a documentação da música popular. (VEIGA, 1988), (VILELA, 2006).

Diante dessa perspectiva, Veiga considera que o termo modinha apareceu em Portugal, talvez derivado de "mote" ou diminutivo de "moda", mas não faz nenhuma colocação sobre a origem do gênero.

Mas, especificamente, a modinha que nos interessa como um importante segmento histórico da canção brasileira é aquela que, tratando do amor em seus termos mais líricos e sentimentais, abrasileirou-se e divulgou-se, sejam quais forme suas origens e influências, portuguesas, italianas, francesas, entre outras, até mesmo traços de derivação africana que já aparecem em finais do século 18 (VEIGA, 1988, p.74).

Sob o conceito de Ferretti pode-se dizer que o autor admite a fusão no processo de origem da modinha.

Também foi possível perceber que alguns autores inseriram a modinha em capítulos de

\footnotetext{
${ }^{18}$ Transcrição feita pela autora. Entrevista concedida a Miguel Ângelo de Azevedo disponível em: https://www.youtube.com/watch?v=Y0G6hN597Ig _ acesso em 20.02.19
} 
seus livros como: Música Popular Brasileira (1960) de Oneyda Alvarenga;

A Pequena História da Música Popular- Da modinha à canção de protesto (1974) e a História social da Música Popular Brasileira (1975) de José Ramos Tinhorão; Momentos da Música Brasileira (1985) de Léa Vinocur Freitag.

A bibliografia também conta com livros que retratam vida e obra de modinheiros como o livro Domingos Caldas Barbosa- o poeta da modinha e do lundu (2004) de José Ramos Tinhorão e Da Modinha ao Sertão - Vida e obra de Catullo da Paixão Cearense de Luiz Américo Lisboa Junior.

A bibliografia sobre modinha conta com obras com análise literária como Doces modinhas pra Iaiá, buliçosos lundus pra ioiô - poesia romântica de música popular no Brasil do século XIX (2008) de Jonas Alves da Silva Junior possuem um viés mais voltado para relação de poesia e música. Silva Junior recolheu mais de 100 poesias musicadas e analisou parte dessas obras observando os temas e motivos recorrentes e o contexto social em que foram produzidas.

$\mathrm{Na}$ nossa pesquisa também identificamos trabalhos como artigos, apostila e dissertações que abordam a modinha como os artigos: Apontamentos musicais dos viajantes (1996) de Ana Maria Kieffer; O Estudo da Modinha Brasileira (1998) e Achegas para um Sarau de Modinhas Brasileiras (1998); A Modinha e o Lundu no Séc. XIX (2004), Problemática da transmissão: estudo de caso com ajuda dos poetas (2008) de Manuel da Veiga; Matrizes - Música Popular no início do Século XIX no Rio de Janeiro. Partituras, performance e escuta da música popular do passado (2008); Inventando moda: a construção da música brasileira (2007); Perdão Emilia! Transmissão oral e aural na canção popular (2008), de Martha Ulhôa; a apostila denominada Apostila de História da Música, material utilizado na UNESP elaborada pelo Prof. Dr. Paulo Castagna; e dissertações como: $A$ "Collecção de modinhas de bom gosto" de João Francisco Leal: um estudo interpretativo por meio de sua contextualização histórico-estético-musical (2008), Dissertação de Sidnei Alferes; Realização de baixos em modinhas do "Jornal de Modinhas" com acompanhamento de cravo pelos milhores autores" editado por F.D. Milcent e P.A. Marchal - Lisboa, 17921797(2009), Dissertação de Guilherme Morais; Modinhas no Brasil Imperial: ornamentação sob a influência dos castrati (2014), dissertação de Adriana Xavier de Almeida e Educação musical: leitura sobre os estudos sobre a modinha de salão carioca da primeira metade do século XIX (2016), dissertação de Jobi Espasiani.

Ao longo do texto as reflexões presentes nestas dissertações, bem como outras teses, artigos e apostilas e trabalhos mais recentes sobre a modinha, ou trabalhos que tenham um 
capítulo sobre a modinha serão abordados e citados juntamente com os livros aqui destacados na revisão bibliográfica.

Com base nas leituras é possível perceber que um grupo de autores como Silvio Romero, Mário de Andrade, Mozart de Araújo, Edigar de Alencar, Gerhad Doderer, Bruno Kiefer, Edilson de Lima e Vicente Salles consideram a modinha do século XVIII decorrente de um processo de adaptação da melodia europeia com forte ligação com a ópera italiana. Um outro grupo, do qual fazem parte Teófilo Braga, Guilherme de Mello e Baptista Siqueira acredita que a modinha é uma justaposição de um tipo lírico antigo proveniente de Portugal. Um terceiro grupo de que participam Cernichiaro e José Ramos Tinhorão, Ruy Nery Vieira, Manuel da Veiga acredita que a modinha foi criada no Brasil e é fruto de mistura. A maior parte dos autores não afirma seu posicionamento categoricamente, mas deixa transparecer nas entrelinhas as ideias em que acredita, e é unânime ao afirmar que a modinha brasileira teria sido muito difundida por Domingos Caldas Barbosa.

Tabela 2- Comparação das linhas de pensamento

\begin{tabular}{|l|l|l|l|l|}
\hline $\begin{array}{l}\text { Linhas de } \\
\text { pensamento }\end{array}$ & Origem & $\begin{array}{l}\text { Usos } \\
\text { sentidos }\end{array}$ & Agente & Circulação \\
\hline 1 & Portugal & $\begin{array}{l}\text { Brasil } \\
\text { (adaptação) }\end{array}$ & $\begin{array}{l}\text { Domingos } \\
\text { Caldas Barbosa }\end{array}$ & $\begin{array}{l}\text { Portugal } \\
\text { Brasil }\end{array}$ \\
\hline 2 & Portugal & $\begin{array}{l}\text { Brasil } \\
\text { (justaposição) }\end{array}$ & $\begin{array}{l}\text { Domingos } \\
\text { Caldas Barbosa }\end{array}$ & $\begin{array}{l}\text { Portugal } \\
\text { Brasil }\end{array}$ \\
\hline 3 & Brasil & - & $\begin{array}{l}\text { Domingos } \\
\text { Caldas Barbosa }\end{array}$ & $\begin{array}{l}\text { Brasil } \\
\text { Portugal } \\
\text { Brasil }\end{array}$ \\
\hline
\end{tabular}

Fonte: Tabela elaborada para esse trabalho

Embora o debate sobre a origem da modinha continue, alguns autores aceitam a terminologia modinha luso-brasileira.

Ulhôa, em seu texto Inventando moda: a construção da música brasileira (ULHÔA,2007) pondera sobre a influência do projeto modernista nacionalista na determinação das matrizes da música brasileira. Após a independência, intelectuais como Manoel de Araújo Porto Alegre preocupava-se com a elaboração de uma cultura brasileira. Discípulo de Jean Baptiste Debret, Porto Alegre seguiu para a França com o seu mestre. Na 
França, colaborou como fundador da revista Nitheroy: Revista Brasiliense. Sciencias, Lettras e Artes escrevendo um artigo que, de certa forma, delineava a cultura brasileira, inserindo um trecho em que descrevia os processos musicais brasileiros já descritos por Debret em Viagem pitoresca e histórica ao Brasil.

Entre nós apparecem dous salientes na Musica, na Bahia, e Norte, Minas geraes, e o Sul: a Música bahiana é o lundum;e a Mineira, a modinha. O lundum é voluptuoso em excesso, melódico; e a modinha é mais grave. Tudo é doce na Bahia, o terreno produz assucar, e come-se chorando com o ardor da malagueta! (PORTO ALEGRE, 1836, p.179).

Ulhôa questiona o destaque dado à modinha e ao lundu, pois após pesquisas feitas em cinco periódicos de diferentes regiões, Ulhôa, percebeu a ausência de referências aos termos dos gêneros considerados como principais matrizes da música popular brasileira. Por outro lado, ela constatou maior ocorrência dos termos nas revistas dos institutos históricos, o que suscitaria uma possibilidade de construção de matrizes por intermédio dos escritores dessas revistas.

[...]A força do pensamento escrito e registrado desses homens é enorme, sendo reproduzida em escritos posteriores e incorporada ao senso comum. Entre os mitos o destaque para a modinha e o lundu, atribuível a Araújo Porto Alegre, ao qual contesta Manoel Querino. [...] (ULHÔA, 2007, p.12).

A necessidade de se criar uma identidade brasileira e a força dos historiadores pode, sem dúvida, ter colaborado para o processo de canonização da modinha e do lundu. Para Vilela, alguns dos fatores que fortalecem a estruturação de um cânone são o etnocentrismo, a dominação cultural e a ação da mídia. Esse processo de canonização da modinha e do lundu, segundo Ulhôa, surgiu no âmbito de um projeto de pesquisa feito pelo musicólogo Mozart de Araújo e vem sendo repetido ano após ano (VILELA,2016); (ULHÔA,2007).

Para Freitas, "o que define e justifica uma criação nacional não é o lugar do seu nascimento, mas sim, a sua aceitação pelo povo" Para ele, a modinha, portuguesa ou brasileira, é essencialmente uma canção, romança ou ária, de fundo amoroso. Pode-se dizer, portanto, que a modinha é bem brasileira, uma vez, que foi aceita, cantada e amada pelo povo brasileiro (FREITAS, 1974, p.5).

Nesse trabalho, utilizaremos a divisão por tipos. Modinhas de salão e modinhas de seresta. As modinhas de salão, podendo ser portuguesas, brasileiras ou luso-brasileiras; e 
as modinhas de seresta, classificadas como brasileiras.

\subsection{Tabela de publicações e seus usos}

A definição das obras a serem catalogadas foi dada pela tabela de publicações. A tabela foi dividida em doze campos, a saber: título, autor, publicador , editor , edição, local, ano de publicação, ano da primeira publicação, páginas, total de obras, meios de expressão, notas da obra e observações.

O segundo campo: autor; nesse caso, é o autor da publicação. Pode ser o mesmo autor das obras musicais ou um organizador do material. O sexto campo referente ao local, foi preenchido com o local de publicação, independentemente do local da elaboração ou da origem do material. O nono campo: total de obras; foi contado incluindo outras classificações de gênero como lundu, valsa, toada. Posteriormente, temos a intenção de especificar o total de modinhas por obra.

Os meios de expressão foram divididos em: somente letra, partitura da linha melódica e partitura para voz e instrumento.

Segue abaixo a tabela : 


\section{Tabela de Publicações}

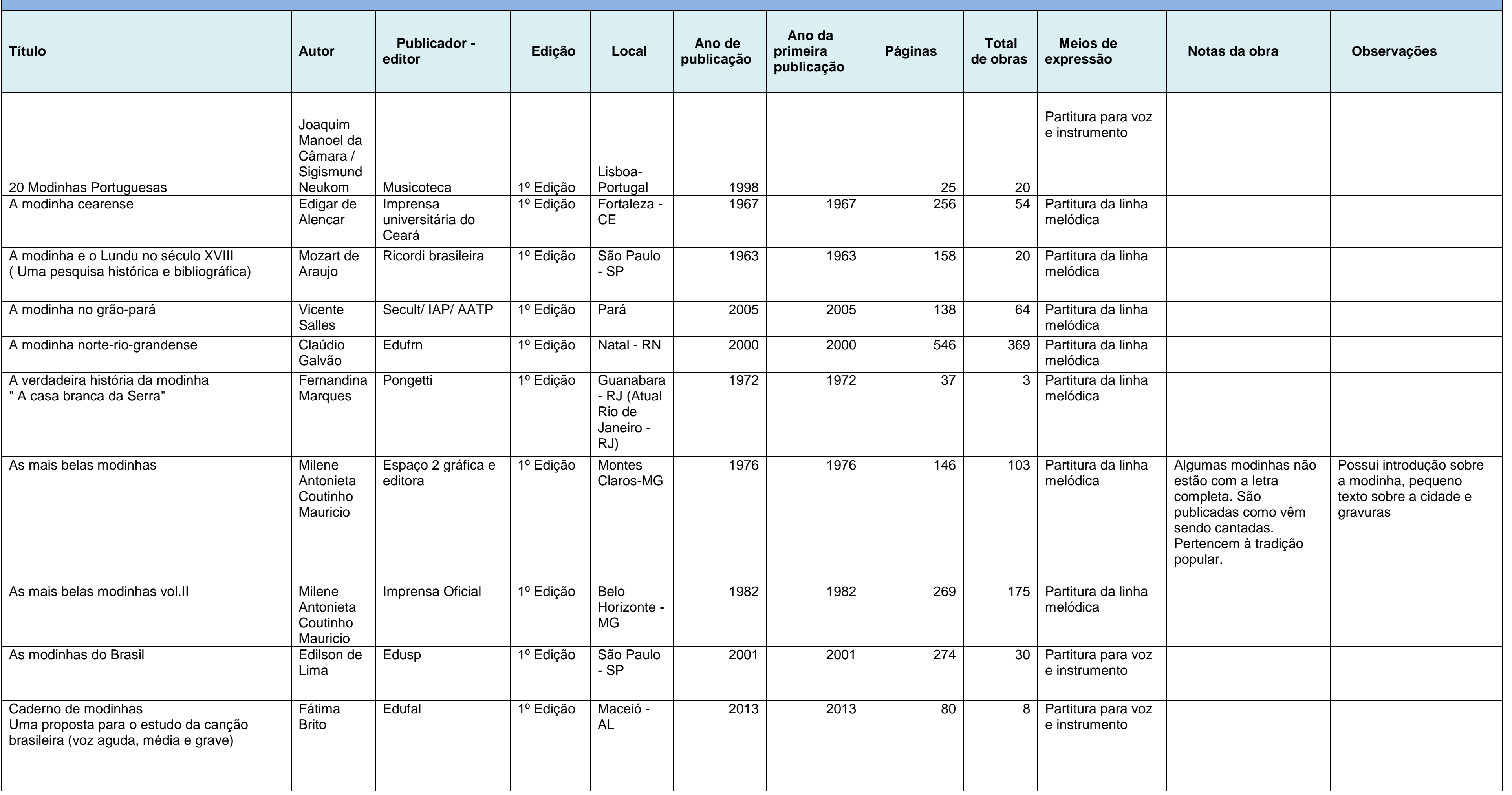




\begin{tabular}{|c|c|c|c|c|c|c|c|c|c|c|c|}
\hline Cancioneiro Popular de Modinhas Brasileiras & $\begin{array}{l}\text { Catullo da } \\
\text { Paixão } \\
\text { Cearense }\end{array}$ & $\begin{array}{l}\text { Livraria do Povo - } \\
\text { Quaresma \& C. } \\
\text { Livreiros Editores }\end{array}$ & 25a edição & $\begin{array}{l}\text { Rio de } \\
\text { Janeiro - } \\
\text { RJ }\end{array}$ & 1908 & 1899 & 220 & 156 & Somente letra & $\begin{array}{l}\text { Esplendida e escolhida } \\
\text { collecção"^de } \\
\text { bellissimas modinhas } \\
\text { populares, escriptas } \\
\text { umas e outras } \\
\text { colleccionaáas, revistas } \\
\text { e melhoradas, postas } \\
\text { taes quaes seus } \\
\text { auctores as } \\
\text { escreveram, e não } \\
\text { stropeádas, } \\
\text { :orrectas e } \\
\text { esphaceladas, como por } \\
\text { ahi andam, de boca em } \\
\text { boca.,'^ na tradicção } \\
\text { oral }\end{array}$ & \\
\hline Canções populares do Brazil & $\begin{array}{l}\text { Julia de } \\
\text { Brito } \\
\text { Mendes }\end{array}$ & $\begin{array}{l}\text { J. Ribeirdo dos } \\
\text { Santos, Livraria } \\
\text { cruz coutinho }\end{array}$ & 1ํEdição & $\begin{array}{l}\text { Rio de } \\
\text { Janeiro - } \\
\text { RJ }\end{array}$ & 1911 & 1911 & 331 & 130 & $\begin{array}{l}\text { Partitura da linha } \\
\text { melódica }\end{array}$ & $\begin{array}{l}\text { Algumas das músicas } \\
\text { que figuram neste livro } \\
\text { são edições dos Srs. M. } \\
\text { A. Gomes Guimarães, } \\
\text { Bevilacqua e Artur } \\
\text { Napoleão, de quem } \\
\text { obtivemos auctorisação } \\
\text { para publical-as aqui, e } \\
\text { em cujos importantes } \\
\text { estabelecimentos são } \\
\text { encontradas á venda } \\
\text { com acompanhamento } \\
\text { para piano. }\end{array}$ & \\
\hline Cantares bohêmios & $\begin{array}{l}\text { Raimundo } \\
\text { Ramos }\end{array}$ & Expressão Gráfica & 1ํEdição & $\begin{array}{l}\text { Fortaleza - } \\
\text { CE }\end{array}$ & 2006 & 2006 & 188 & 110 & $\begin{array}{l}\text { Partitura da linha } \\
\text { melódica }\end{array}$ & & \\
\hline Collecção de modinhas de bom gosto & $\begin{array}{l}\text { João } \\
\text { Francisco } \\
\text { Leal }\end{array}$ & UNICAMP & 1edicão & Campinas & 2008 & 1830 & 221 & 12 & $\begin{array}{l}\text { Partitura para voz } \\
\text { e instrumento }\end{array}$ & & $\begin{array}{l}\text { Coletânea inserida na } \\
\text { dissertação A "Colleç̧ão } \\
\text { de modinhas de Bom } \\
\text { Gosto " de João } \\
\text { Francisco Leal: Um } \\
\text { estudo interpretativo por } \\
\text { meio de sua } \\
\text { contextualização } \\
\text { histórico-estético-musical } \\
\text { de Sidnei Alferes }\end{array}$ \\
\hline $\begin{array}{l}\text { Collecção Modinhas Brazileiras com } \\
\text { Accompanhamento de Piano de varios } \\
\text { authores }\end{array}$ & $\begin{array}{l}\text { Pierre } \\
\text { Laforge }\end{array}$ & Pierre Lagorge & $1^{\underline{a} \text { edição }}$ & $\begin{array}{l}\text { Rio de } \\
\text { Janeiro - } \\
\text { RJ }\end{array}$ & 1842 & ? & 99 & 59 & $\begin{array}{l}\text { Partitura para voz } \\
\text { e instrumento }\end{array}$ & & \\
\hline
\end{tabular}




\begin{tabular}{|c|c|c|c|c|c|c|c|c|c|c|}
\hline Contribuição para o estudo da modinha & $\begin{array}{l}\text { Eunice } \\
\text { Evanira } \\
\text { Pereira } \\
\text { Mendes }\end{array}$ & $\begin{array}{l}\text { Prefeitura do } \\
\text { Municipio de São } \\
\text { Paulo } \\
\text { Secretaria da } \\
\text { educação e cultura } \\
\text { Divisão do arquivo } \\
\text { histórico }\end{array}$ & 1ํEdição & $\begin{array}{l}\text { São Paulo } \\
\text { - SP }\end{array}$ & 1959 & 1959 & 153 & 32 & $\begin{array}{l}\text { Partitura da linha } \\
\text { melódica }\end{array}$ & $\begin{array}{l}\text { Possui análise } \\
\text { musicológica das obras - } \\
\text { compasso/ritmo/extensão } \\
\text { tonal/direção de linha } \\
\text { melódica/número de } \\
\text { compassos/modos/ } \\
\text { intervalos } \\
\text { empregados/extensão } \\
\text { dos motivos/quanto à } \\
\text { estrutura musical. }\end{array}$ \\
\hline Lundus e modinhas antigas - Século XIX & $\begin{array}{l}\text { Esther } \\
\text { Pedreira }\end{array}$ & Tempo brasileiro & 1ํEdição & $\begin{array}{l}\text { Rio de } \\
\text { Janeiro - } \\
\text { RJ }\end{array}$ & 1981 & 1981 & 57 & 8 & $\begin{array}{l}\text { Partitura da linha } \\
\text { melódica }\end{array}$ & \\
\hline Lyra Popular brasileira & $\begin{array}{l}\text { José Vieira } \\
\text { Pontes }\end{array}$ & $\begin{array}{l}\text { C. Teixeira \& Cia } \\
\text { Editores }\end{array}$ & $8^{\circ}$ Edição & $\begin{array}{l}\text { São Paulo } \\
\text { - SP }\end{array}$ & 1927 & & 437 & 205 & Somente letra & \\
\hline $\begin{array}{l}\text { Minas sempre-viva - Pesquisa Histórica do } \\
\text { Folclore Musical Mineiro }\end{array}$ & $\begin{array}{l}\text { Luiz } \\
\text { Claudio }\end{array}$ & $\begin{array}{l}\text { Léo Christiano } \\
\text { Editorial Ltda }\end{array}$ & $1^{0}$ E Edição & $\begin{array}{l}\text { Rio de } \\
\text { Janeiro - } \\
\text { RJ }\end{array}$ & 1983 & 1983 & 58 & 27 & $\begin{array}{l}\text { Partitura da linha } \\
\text { melódica }\end{array}$ & \\
\hline Modinhas & $\begin{array}{l}\text { Catullo da } \\
\text { Paixão } \\
\text { Cearense }\end{array}$ & Fermata do Brasil & $3^{\circ}$ Edição & $\begin{array}{l}\text { São Paulo } \\
\text { - SP }\end{array}$ & 1972 & & 451 & 178 & Somente letra & \\
\hline Modinhas \& Serestas valsas \& Canções & $\begin{array}{l}\text { Paulo } \\
\text { Pimenta de } \\
\text { Mello }\end{array}$ & Plast-Set & 1ํㅡdição & $\begin{array}{l}\text { Ribeirão } \\
\text { Preto - SP }\end{array}$ & 1985 & 1985 & 183 & 87 & Somente letra & \\
\hline Modinhas Antigas & $\begin{array}{l}\text { Ruy } \\
\text { Pimenta } \\
\text { Filho }\end{array}$ & Editora Veja S.A & 10 Edição & $\begin{array}{l}\text { Belo } \\
\text { Horizonte - } \\
\text { MG }\end{array}$ & 1980 & 1980 & 320 & 138 & $\begin{array}{l}\text { Partitura da linha } \\
\text { melódica }\end{array}$ & \\
\hline Modinhas de nossa terra & $\begin{array}{l}\text { Angélica } \\
\text { de } \\
\text { Rezende }\end{array}$ & $\begin{array}{l}\text { Carneiro \& Cia } \\
\text { Editores }\end{array}$ & 1ํEdição & $\begin{array}{l}\text { Belo } \\
\text { Horizonte - } \\
\text { MG }\end{array}$ & 1954 & 1954 & 64 & 12 & $\begin{array}{l}\text { Partitura da linha } \\
\text { melódica }\end{array}$ & \\
\hline Modinhas do passado & $\begin{array}{l}\text { Baptista } \\
\text { Siqueira }\end{array}$ & $\begin{array}{l}\text { Folha carioca } \\
\text { editora Ltda }\end{array}$ & $2^{0}$ Edição & $\begin{array}{l}\text { Rio de } \\
\text { Janeiro - } \\
\text { RJ }\end{array}$ & 1979 & 1979 & 373 & 104 & $\begin{array}{l}\text { Partitura da linha } \\
\text { melódica }\end{array}$ & \\
\hline Modinhas e Canções & $\begin{array}{l}\text { Heitor } \\
\text { Villa-Lobos }\end{array}$ & $\begin{array}{l}\text { Editions Max } \\
\text { Eschig }\end{array}$ & 1ํEdição & $\begin{array}{l}\text { Paris - } \\
\text { Franca }\end{array}$ & 1957 & 1957 & 23 & 7 & $\begin{array}{l}\text { Partitura para voz } \\
\text { e instrumento }\end{array}$ & \\
\hline
\end{tabular}




\begin{tabular}{|c|c|c|c|c|c|c|c|c|c|c|}
\hline Modinhas imperiais & $\begin{array}{l}\text { Mário de } \\
\text { Andrade }\end{array}$ & Itatiaia Limitada & 3 Edição & \begin{tabular}{|l} 
Belo \\
Horizonte - \\
MG
\end{tabular} & 1980 & 1930 & 51 & 16 & $\begin{array}{l}\text { Partitura para voz } \\
\text { e instrumento }\end{array}$ & $\begin{array}{l}\text { A presente edição de } \\
\text { Modinhas Imperiais da } \\
\text { terceira que se faz } \\
\text { deste livro, é o volume } \\
\text { numérico XIX das } \\
\text { "Obras completas de } \\
\text { Mário de Andrade". Os } \\
\text { filmes do texto foram } \\
\text { fotografádos da 2a } \\
\text { edição publicada pela } \\
\text { Livraria Martins Editora, } \\
\text { São Paulo, em fevereiro } \\
\text { de } 1964, \text { e gentilmente } \\
\text { cedidos pelo seu } \\
\text { presidente José de } \\
\text { Barros Martins, Revisão } \\
\text { de partituras pelo } \\
\text { escritor e musicólogo } \\
\text { Juvenal Fernandes, e } \\
\text { retoques das mesmas } \\
\text { pelo musicólogo Miguel } \\
\text { Poligiccio. }\end{array}$ \\
\hline Modinhas, lunduns e cançonetas & $\begin{array}{l}\text { Manuel } \\
\text { Morais }\end{array}$ & $\begin{array}{l}\text { Imprensa nacional - } \\
\text { Casa da moeda }\end{array}$ & 1ํEdição & Portugal & 2000 & 2000 & 183 & 25 & $\begin{array}{l}\text { Partitura para voz } \\
\text { e instrumento }\end{array}$ & \\
\hline Mysterios do violão & $\begin{array}{l}\text { Eduardo } \\
\text { das Neves }\end{array}$ & Livraria do Povo & $1\{$ edição & $\begin{array}{l}\text { Rio de } \\
\text { Janeiro - } \\
\text { RJ }\end{array}$ & 1905 & 1905 & 62 & 68 & Somente letra & \\
\hline $\begin{array}{l}\text { Nova colecção de Hymnos, canções e } \\
\text { lundus. }\end{array}$ & $\begin{array}{l}\text { Joaquim } \\
\text { Norberto } \\
\text { de Souza e } \\
\text { Silva }\end{array}$ & Livraria Garnier & 1ํEdição & \begin{tabular}{|l} 
Rio de \\
Janeiro - \\
RJ
\end{tabular} & 1878 & 1878 & 271 & 88 & Somente letra & $\begin{array}{l}\text { Tencionavamos dar } \\
\text { neste terceiro tomo um } \\
\text { trecho do ilustrado Sr. } \\
\text { M. de Araújo Porto } \\
\text { Alegre, barão de Santo } \\
\text { Ângelo, sobre a musica } \\
\text { no Brazil, mas baldados } \\
\text { foram os esforços que } \\
\text { fizemos para obter a } \\
\text { obra em que foi } \\
\text { publicado em } 1836 \text {, isto } \\
\text { é, Nictheroy, Revista } \\
\text { Braziliense, Imprensa } \\
\text { em Paris. Como temos } \\
\text { fé que a presente } \\
\text { edição se esgotará } \\
\text { rapidamente } \\
\text { Completaremos a nossa } \\
\text { tarefa em uma nova } \\
\text { edição mais } \\
\text { desenvolvida, e na qual } \\
\text { procuraremos dar a } \\
\text { auctoria de muitas } \\
\text { composições que } \\
\text { andam por ahi sem o } \\
\text { nome de seus } \\
\text { auctores.Pedimos aqui } \\
\text { a quem se interessar } \\
\text { pelo complemento desta }\end{array}$ \\
\hline
\end{tabular}




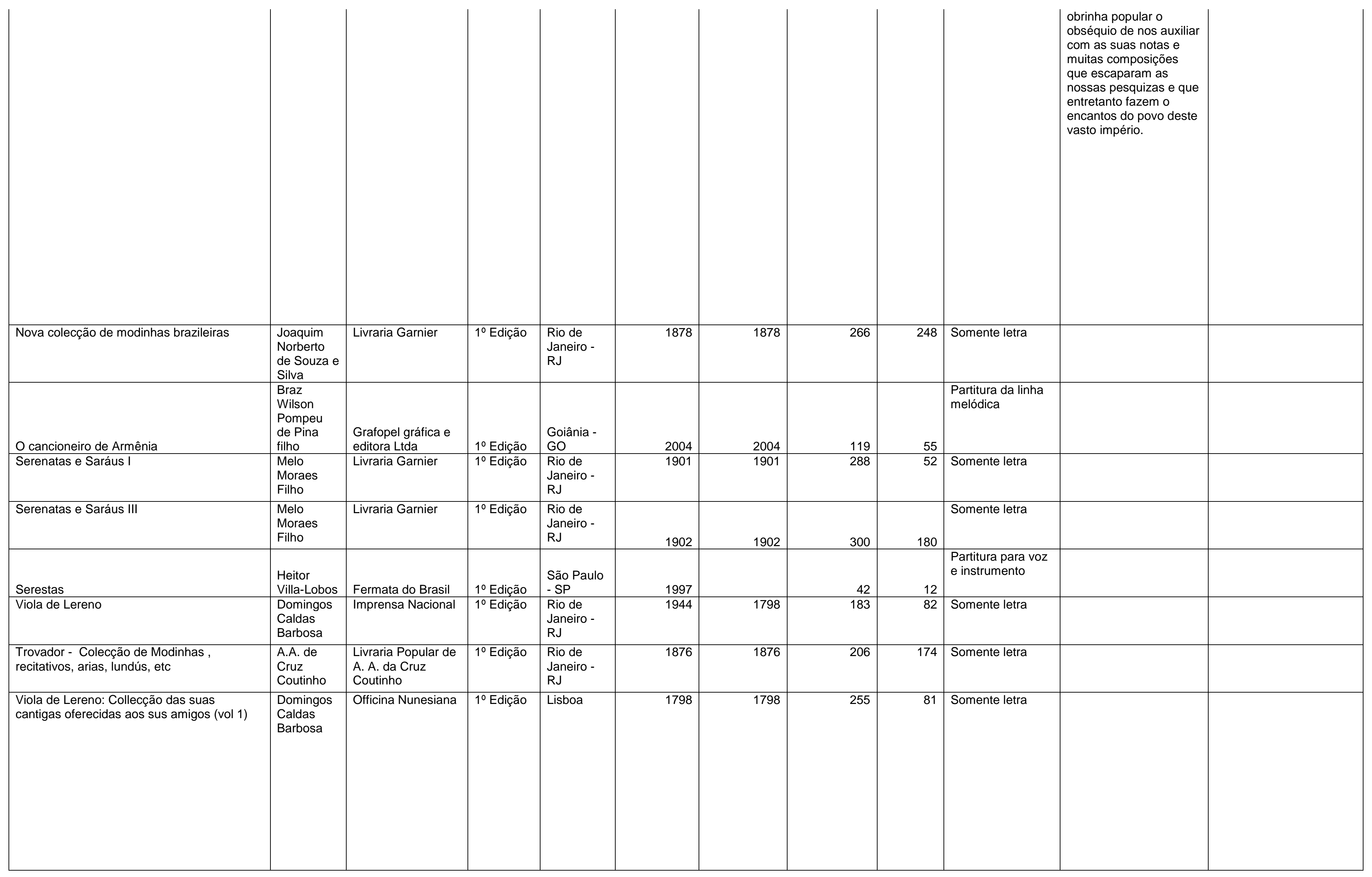


A lista de modinhas foi pensada a partir da necessidade de localizar as modinhas dentro das coletâneas citadas na lista de publicações. Como investigar e refletir sobre a circulação de uma obra se não for possível encontrá-la? Como comparar modinhas observando possíveis variações sem saber onde estão? Numa busca rápida nas bibliotecas, é possível encontrar modinhas que foram impressas como partitura avulsa; porém as modinhas que estão inseridas em coletâneas, álbuns e cadernos de música, ou em livros, em geral, têm a palavra chave da busca pelo título do livro, dificultando a localização dos pares.

A tabela foi dividida em treze campos. Alguns deles serão utilizados no projeto de mestrado e três deles serão preenchidos ao longo das pesquisas durante e após o mestrado visando o aprofundamento no tema. Os dois primeiros campos são título e primeira frase. Como alguns títulos são homônimos, esperamos, dessa forma, dirimir dúvidas. Por outro lado, algumas modinhas que tinham título em determinado localidade apareceram em outra localidade como nome diferente; por essa razão a primeira frase da modinha poderá colaborar na identificação de uma obra. Observando-se a semelhança na primeira frase é possível investigar se é o mesmo material musical ou não. Os campos seguintes são: compositor, poeta e fonte (coletânea, álbum, caderno, cancioneiro).

O próximo campo chamado meios de expressão é mais detalhado que o modelo da tabela anterior : somente letra, melodia com letra separada, melodia com letra ajustada e partitura especificando os instrumentos. Em seguida, os campos: notas da música, notas do texto, notas da interpretação presentes no material irão compor o cenário musical, costumes, instrumentação, vocalidade, gravações, caráter, andamentos, dentre outros. São dados que poderão colaborar no embasamento de questões referentes às práticas interpretativas.

Acreditamos que a elaboração da lista de modinhas com 3090 obras presentes nas coletâneas, seja essencial para a busca e a identificação da circulação. A tabela está disponibilizada no seguinte endereço:

\section{http://www2.eca.usp.br/comunicantus/projetomodinhas}

Os campos fórmula de compasso e tonalidade serão preenchidos futuramente, visando outro objetivo no uso da tabela que é observar as diferenças entre as abordagens feitas por Bruno Kiefer e Baptista Siqueira. Kiefer na sua amostragem encontrou modinhas maiores e menores em igual quantidade; e Siqueira encontrou maior número de modinhas na tonalidade menor.

Sobre as fórmulas de compasso, Mário de Andrade enumera maior ocorrência de modinhas com compasso binário e observa que o compasso ternário apareceu na sua 
decadência, final do século XVIII. Pretendemos em pesquisa a longo prazo observar as datas das modinhas e sua relação com as fórmulas de compasso, observando-se a influência que a valsa possa ter exercido nas composições.

\section{2 - SALÃO E SERESTA}

O nome modinha está presente em livros, coletâneas e partituras desde a sua primeira aparição no século XVIII até o presente momento; porém acreditamos que existam modinhas dentro da modinha. Espasiani, em sua dissertação, tem vários conceitos para a mesma denominação, observando que o conceito é produto do recorte cultural; ele conclui, portanto, que por trás do nome modinha é possível perceber diversos recortes culturais dependendo do tempo e da comunidade em que está inserida.

Observamos que o termo canção também possui em seu conceito diversos sentidos. No dicionário de Ernesto Vieira, de 1889, publicado em Lisboa, ele diz que a canção é "Pequeno poema dividido em coplas ou estrofes ao qual se applica uma aria simples, fácil de apprender e de conservar de côr. A canção é originária da França, creou se nesse paiz, cerca do século XVIII." Nesse verbete, Vieira também atesta que o catálogo musical da biblioteca de D. João IV possui centenas de canções. Porém, ele enumera as canções sempre com um complemento: canções de beber, canções de guerra, canções de mesa.

Muitas canções são classificadas a partir da locução adjetiva que a acompanha o que, de certa forma, imprime um caráter de função: canção de guerra, canção de roda, canção de ninar, canção de beber, canção de caça, canção de colheita, canção de trabalho, canção de protesto. Essa atribuição dá à canção uma função e retira dela a possibilidade da ser uma composição por si só.

No dicionário Musical Brasileiro, de Mário de Andrade, publicado em 1989, o termo canção recebe o seguinte verbete.

Composição em verso. Na Pequena história da música, Mário de Andrade analisa a canção européia: "O séc. XVI é a fase da canção. Porém agora o que se entende por canção não é uma toada de gênero popular, nem se inventou ainda a mania de imitar popularescamente o povo. Trata-se de uma forma desenvolvida e aprimorada, um pouco amaneirada mesmo, como poesia. Poeticamente há grande variedade na forma das estrofes, cada estrofe, em geral seguida por estribilho. O tamanho das canções também varia muito, e se algumas são pequeninas, outras não acabam mais, de tamanhas. Seus temas preferidos são o amor...e o amor. Em geral o amor. Porém amor cortês, cheios de delicadezas e grã-finismo de expressão. Às vezes se canta a natureza também (ANDRADE,1989,p.87). 
O conceito de Mário de Andrade fala da canção de amor e curiosamente nesse caso não é utilizada a locução adjetiva "de amor" como complemento. Ficando, portanto, implícito que as canções que não estão acompanhadas de um complemento são canções com temáticas de amor.

Na Europa, além das cantigas de amor e de amigo, também existiam as canções de gesta, poemas que narravam aventuras de cavaleiros, como é o caso da Chanson de Roland (Canção de Rolando). Observamos também que algumas composições instrumentais foram chamadas de canções; o mesmo ocorre com modinhas, como demonstramos nos exemplos de obras instrumentais abaixo:

Canção Sertaneja - 1928 - Mozart Camargo Guarnieri - piano

Peças Infantis - I - Canção - Alberto Nepomuceno - piano

Suíte Mirim: Modinha - 1953 - Mozart Camargo Guarnieri - piano

Modinha - 1947 - Francisco Mignoni - Violoncelo e piano

Modinha $-1^{o}$ movimento - Concerto para piano e orquestra de Hekel Tavares Op.105-n²

Convém ainda citar, que, em alguns casos, os termos canção e modinha estão presentes na literatura sem uma música, como por exemplo: Canção do Exílio de Gonçalves Dias e Modinha de Cecília Meireles, dentre outros.

Essa pesquisa não se aprofundará em questões de terminologia na música brasileira, mas não podemos deixar de refletir sobre o assunto pela própria demanda de classificação do repertório. Afinal, quando e como o termo canção passou a designar a canção como conhecemos hoje? Canção e modinha falam de amor, mas o que pode ser considerado modinha e o que pode ser considerado canção? Canção é modinha? Modinha é canção? São sinônimos? Esses questionamentos que não conseguiremos responder nesse momento; porém, pretendemos continuar essa busca. A polêmica surge por percebermos álbuns com títulos como: Modinhas e Canções de Heitor Villa-Lobos.

Nesse trabalho consideraremos a modinha como um tipo de canção de amor, não o amor cortês cheio de delicadezas, portanto positivo, descrito por Mário de Andrade, mas a descrição feita por Galvão, um amor que não tem êxito, um amor sem sucesso, negativo.

Os termos salão e seresta apareceram na literatura como complemento do nome modinha, o que, de certa forma, delimitou a modinha em dois tipos. Como havíamos observado anteriormente, em algumas coletâneas, o termo modinha, quando aparece sozinho, 
principalmente em publicações feitas no Brasil, no século XX, abrange diversos gêneros como samba, marcha, xote, valsa, dentre outros.

Nesse capítulo, abordaremos o cenário musical presente no salão e na seresta observando as semelhanças e diferenças entre seus espaços geográficos, costumes, personagens, instrumentações, linha melódica, temas, estruturas poéticas e formas musicais.

Baptista Siqueira, em Modinhas do Passado, dividiu as modinhas urbanas por tipos: modinhas de salão e modinhas de seresta. De certa forma, o autor entende essa classificação como proveniente de uma diferença na inspiração e na construção das modinhas. Para Siqueira, as primeiras seriam veículos de amores furtivos utilizando-se o romantismo nos verso; as segundas seriam mais espontâneas, inspiradas na poética do céu iluminado (SIQUEIRA,1979, p.25).

Nas entrelinhas, é possível perceber que, para Siqueira, a delimitação está intrinsecamente relacionada ao texto (letra da música); ou seja, a modinha de salão está mais ligada aos movimentos literários como Romantismo e Arcadismo, enquanto que a modinha de seresta teria seus versos mais ligados à poesia popular.

No Dicionário Musical Brasileiro de Mário de Andrade, o termo modinha é descrito como canto de salão; vale ressaltar que o autor não incluiu nessa obra o significado da palavra salão. (ANDRADE, 1989, p.344)

Um salão cultural era uma reunião mundana, normalmente organizada por uma anfitriã que recebia, em sua casa ou num espaço ao qual tinha acesso, amigos e personalidades da sociedade com a finalidade de trocar ideias sobre temas de índole política, cultural ou filosófica. A anfitriã escolhia os motes dos debates e moderava as discussões. Para muitas mulheres, esta era uma possibilidade única de adquirirem conhecimentos, bem como de exprimirem as suas ideias ou apresentarem as suas obras. Os salões tinham um horário e uma regularidade definida, e eram anunciados previamente em boletins. A segurança destes espaços íntimos e selectos proporcionava o ambiente ideal para cultivar amizades ou inimizades, realizar contactos profissionais ou iniciar relacionamentos amorosos. Celebraram-se casamentos entre frequentadores dos mesmos salões, como aconteceu com Paul Bourget e Minnie David (CORTEZ,2012, p.13)

O termo salão além de designar um espaço amplo onde seria possível realizar festas com música e dança, tem um sentido figurado: encontro de pessoas da sociedade, intelectuais, artistas, políticos. Esses salões aconteceram em muitos países como França, Rússia, Portugal, Itália, Brasil, promovidos por princesas, condessas, marquesas e damas da sociedade. 
Importante frisar que esses espaços eram os únicos que possibilitavam a expressão das mulheres da nobreza e da burguesia nas artes. Às mulheres não cabia o direito de expor-se publicamente, embora fizesse parte de sua educação o estudo da música, da pintura, da poesia, dentre outras habilidades. Nos encontros promovidos em residências, homens e mulheres tocavam, dançavam, recitavam.

A palavra salão teria seu significado aproximado ao do termo sarau que, segundo Andrade, é uma reunião dançante, em geral noturna, organizada em casas particulares, clubes ou teatros (ANDRADE, 1989, p.465)

Num salão esmeram-se várias artes: a de receber ou preparar um ambiente de cordialidade e espírito; a de entreter a apalestra ou cultivar o humour; dançar uma valsa ou cantar uma ária; declamar ou inspirar versos, criticar com graça e sem maledicência, realçar a beleza feminina nas últimas invenções da moda...(PINHO, 1942,p.7).

O termo salão ainda traz implícito o valor simbólico de expressar uma reunião proposta por uma pessoa ou grupo com alto poder aquisitivo. A utilização do designativo "de salão" para modinha de salão ou canto de salão poderia ter intenção de transpor esse significado simbólico? Nesse caso, as composições seriam feitas por músicos com "nível musical elevado"? Ou será que seriam compostas para ouvintes de alto poder aquisitivo? Ou ouvintes com refinado gosto estético? Modinha de salão seria uma música diferenciada, superior, composta para ambientes finos por compositores de alto nível?

Como observou Espasiani, Andrade delimitou a modinha como modinha de salão, e listou alguns critérios:

Nesse estudo, o pesquisador paulistano chamou de modinha de salão toda modinha cantada nos ambientes aristocráticos e burgueses entre o período colonial e segundo império - seja no Brasil, seja em Portugal. Esta denominação, especificada pela adjetivação de salão, define, pois, um tipo de modinha, o qual é delimitado pelas pessoas que a praticavam, pela formação musical que tinham, pelo espaço no qual era praticada e pelo tempo histórico (ESPASIANI,2016, p.11).

Embora o termo modinha acrescentado da locução adjetiva de salão tenha sido utilizado por Mário de Andrade no prefácio de Modinha Imperiais, em 1930, não foi incorporado à terminologia dos estudos seguintes, como é possível perceber pelos títulos presentes nos trabalhos acadêmicos listados na bibliografia e na tabela de publicações apresentada a seguir: 


\section{Tabela de Publicações}

Título

Autor

Joaquim Manoel da Câmara / Sigismund Neukom

A modinha cearense

Edigar de Alencar

A modinha e o Lundu no século XVIII

( Uma pesquisa histórica e bibliográfica)

Mozart de Araujo

A modinha no grão-pará

Vicente Salles

A modinha norte-rio-grandense

Claúdio Galvão

A verdadeira história da modinha

" A casa branca da Serra"

Fernandina Marques

As mais belas modinhas

Milene Antonieta Coutinho Mauricio

Milene Antonieta Coutinho Mauricio

As mais belas modinhas vol.II

As modinhas do Brasil

Edilson de Lima

Caderno de modinhas: Uma proposta para o estudo da canção brasileira (voz aguda, média e grave)

Fátima Brito

Cancioneiro Popular de Modinhas Brasileiras Catullo da Paixão Cearense

Canções populares do Brazil Julia de Brito Mendes

Cantares bohêmios

Raimundo Ramos 


\begin{tabular}{|c|c|}
\hline Collecção de modinhas de bom gosto & João Francisco Leal \\
\hline $\begin{array}{l}\text { Collecção Modinhas Brazileiras com } \\
\text { Accompanhamento de Piano de varios authores }\end{array}$ & Pierre Laforge \\
\hline Contribuição para o estudo da modinha & $\begin{array}{l}\text { Eunice Evanira Pereira } \\
\text { Mendes }\end{array}$ \\
\hline Lundus e modinhas antigas - Século XIX & Esther Pedreira \\
\hline Lyra Popular brasileira & José Vieira Pontes \\
\hline $\begin{array}{l}\text { Minas sempre-viva - Pesquisa Histórica do Folclore } \\
\text { Musical Mineiro }\end{array}$ & Luiz Claudio \\
\hline Modinhas & Catullo da Paixão Cearense \\
\hline Modinhas \& Serestas valsas \& Canções & Paulo Pimenta de Mello \\
\hline Modinhas Antigas & Ruy Pimenta Filho \\
\hline Modinhas de nossa terra & Angélica de Rezende \\
\hline Modinhas do passado & Baptista Siqueira \\
\hline Modinhas e Canções & Heitor Villa-Lobos \\
\hline Modinhas imperiais & Mário de Andrade \\
\hline Modinhas, lunduns e cançonetas & Manuel Morais \\
\hline Mysterios do violão & Eduardo das Neves \\
\hline Nova colecção de Hymnos, canções e lundus. & $\begin{array}{l}\text { Joaquim Norberto de Souza e } \\
\text { Silva }\end{array}$ \\
\hline Nova colecção de modinhas brazileiras & $\begin{array}{l}\text { Joaquim Norberto de Souza e } \\
\text { Silva }\end{array}$ \\
\hline
\end{tabular}




\begin{tabular}{|l|l|} 
& \\
O cancioneiro de Armênia & $\begin{array}{l}\text { Braz Wilson Pompeu de Pina } \\
\text { filho }\end{array}$ \\
\hline Serenatas e Saráus I & Melo Moraes Filho \\
\hline Serenatas e Saráus III & Melo Moraes Filho \\
\hline Serestas & Heitor Villa-Lobos \\
\hline $\begin{array}{l}\text { Trovador - Colecção de Modinhas, recitativos, arias, } \\
\text { lundús, etc }\end{array}$ & A.A. de Cruz Coutinho \\
\hline & \\
Viola de Lereno & Domingos Caldas Barbosa \\
\hline $\begin{array}{l}\text { Viola de Lereno: Colleção das suas cantigas } \\
\text { oferecidas aos sus amigos (vol 1) }\end{array}$ & Domingos Caldas Barbosa \\
\hline
\end{tabular}

Fonte: Tabela de publicações

Espasiani acredita não ter sido dada a devida importância pelos pesquisadores e observa que a não especificação causou uma confusão. Essa vagueza permitiu que objetos distintos fossem tratados com o mesmo nome. O pesquisador conclui que a palavra modinha foi usada indiscriminadamente para referir-se ao mais diversos gêneros de canção de amor (ESPASIANI, 2016). Em nossa pesquisa, observamos que, em algumas coletâneas, além de modinhas, os autores agruparam outros gêneros como toadas, marchas, tangos, valsas, sambas. O termo modinha foi considerado como um genérico de canção. 
Ilustração 1- Capa do livro A modinha cearense

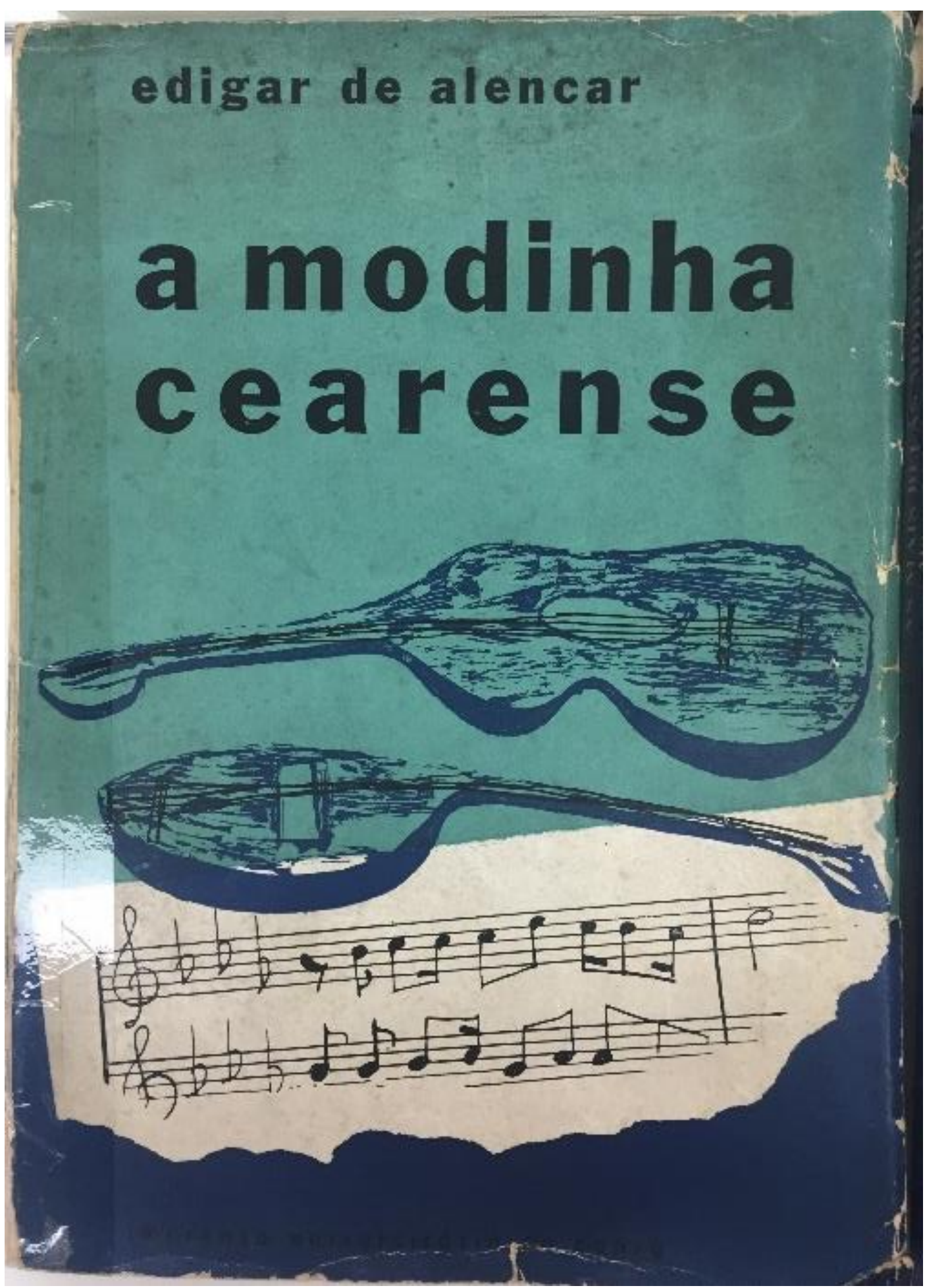

Fonte: A modinha cearense 
Figura 1- Partitura do tango Cangatís

\section{CANGATIS}

\section{TANGO}

musiea de Ramos Cotóco

Dosento musical de Gilberto Petronitlo
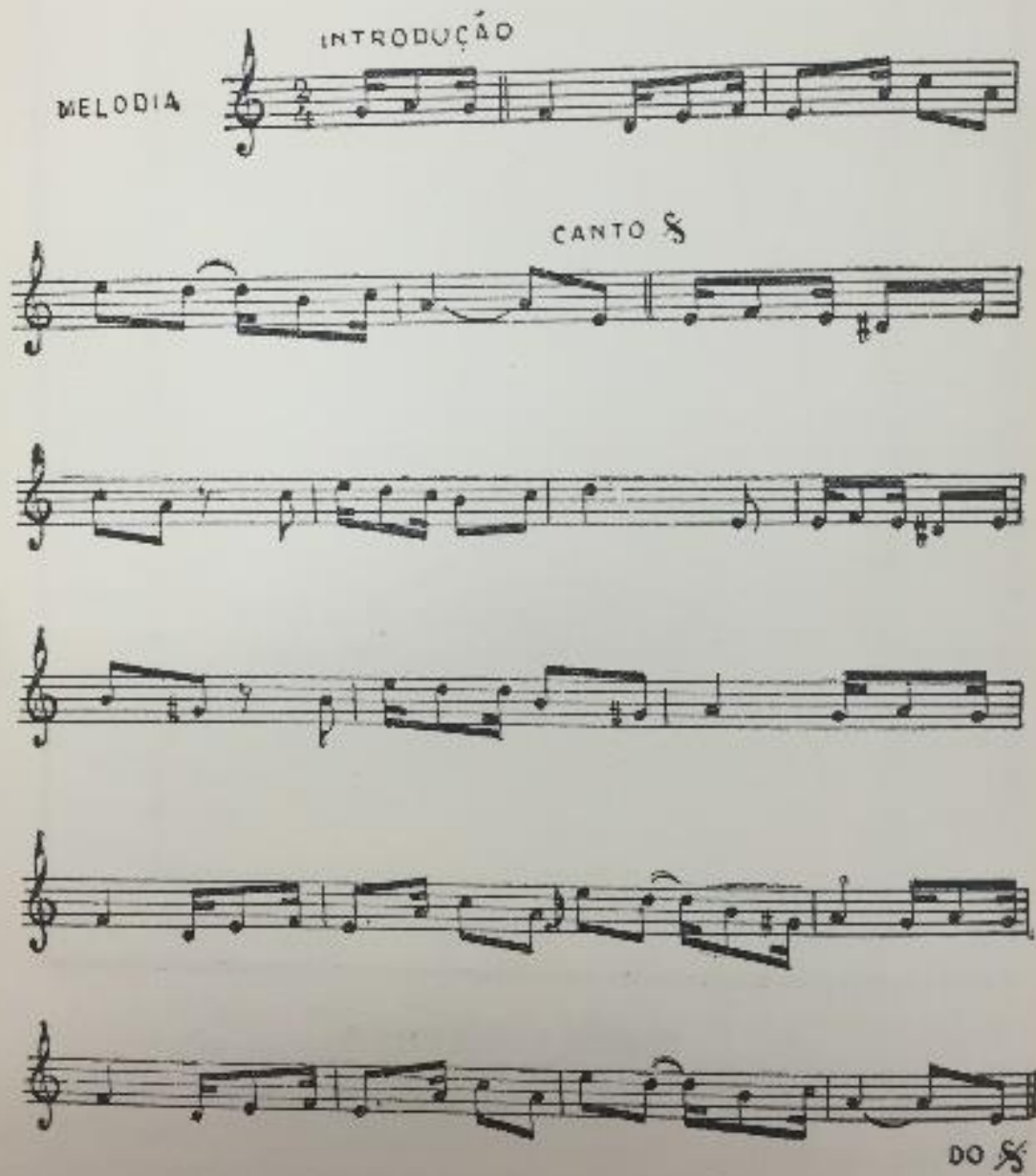

Fonte: A modinha cearense 
Figura 2- Partitura da marcha Todos nós somos Queiroz

\section{TODOS NÓS SOMOS QUEIROZ}

\section{MARCHA}

Ohúsica de Oscar Feital e Antonio Raiol

Desento musical de Griberto Petronillo
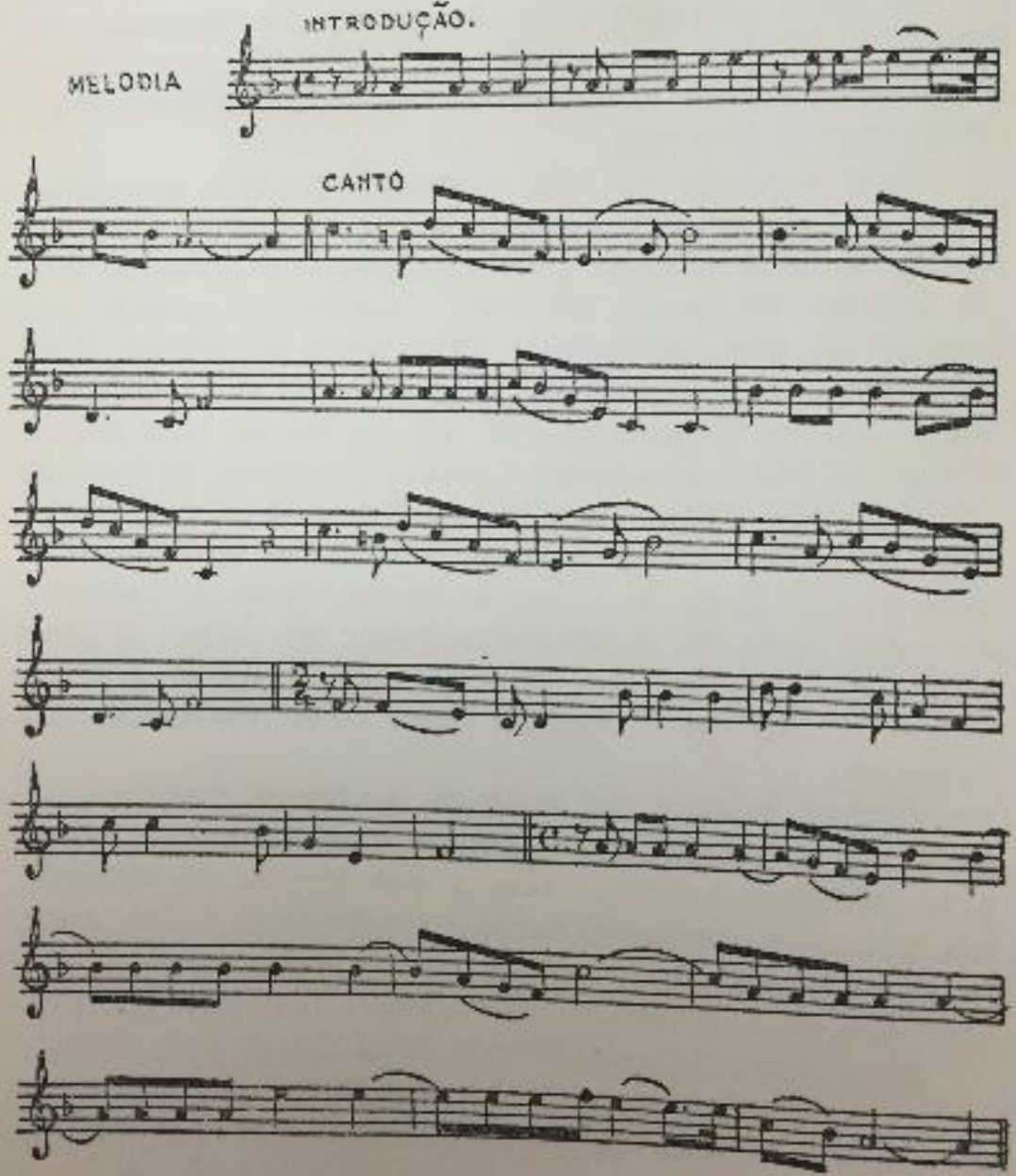

Fonte: A modinha cearense 


\section{COIO' SEM SORTE}

\section{SAMBINHA}

ORúsica de Ramos Cotòco

Deseriho musical de Gilberto Petronilla

MELODIA $\frac{1}{4} \operatorname{lich}^{2}$
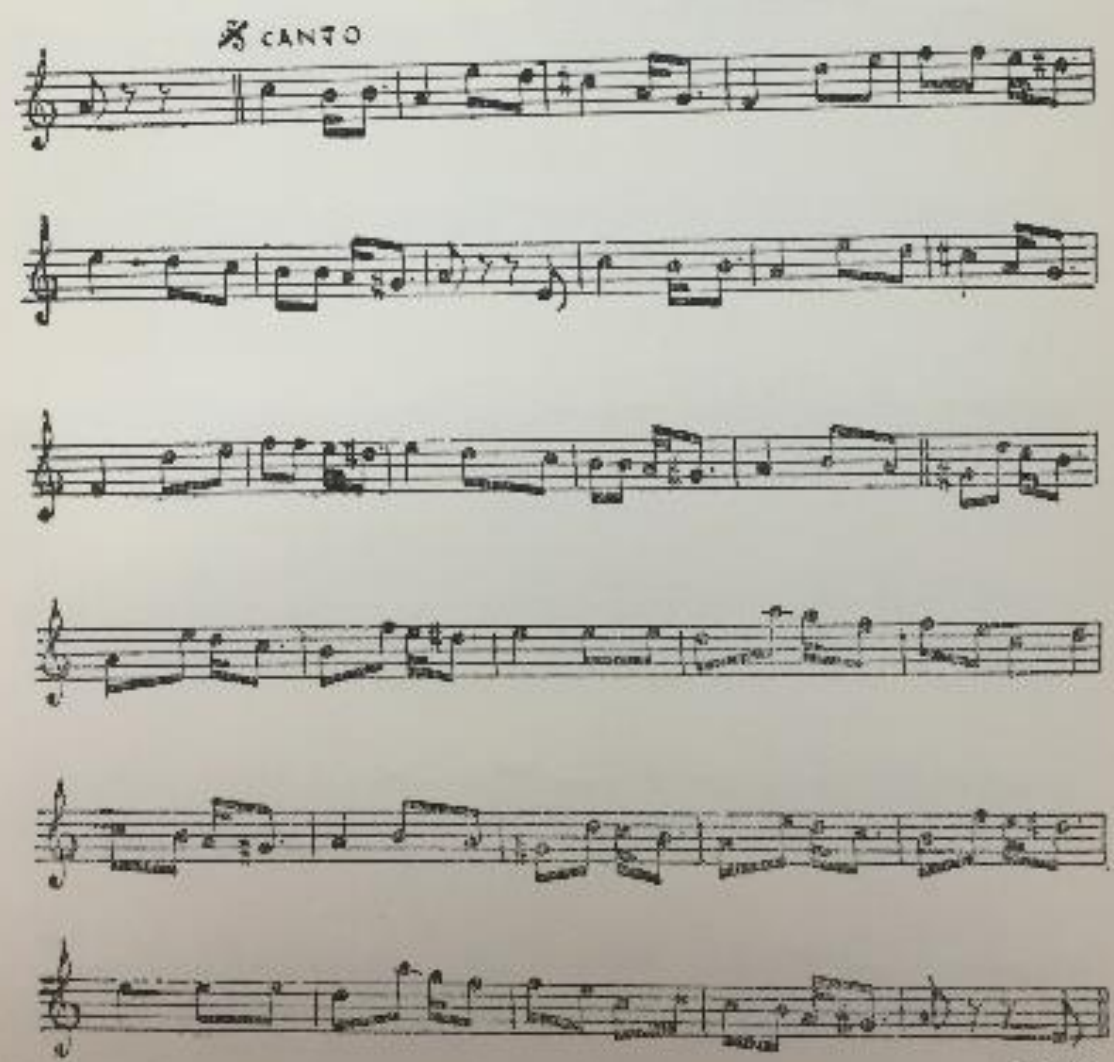

0055

Fonte: A modinha cearense 
Ilustração 2- Capa do livro As mais belas modinhas

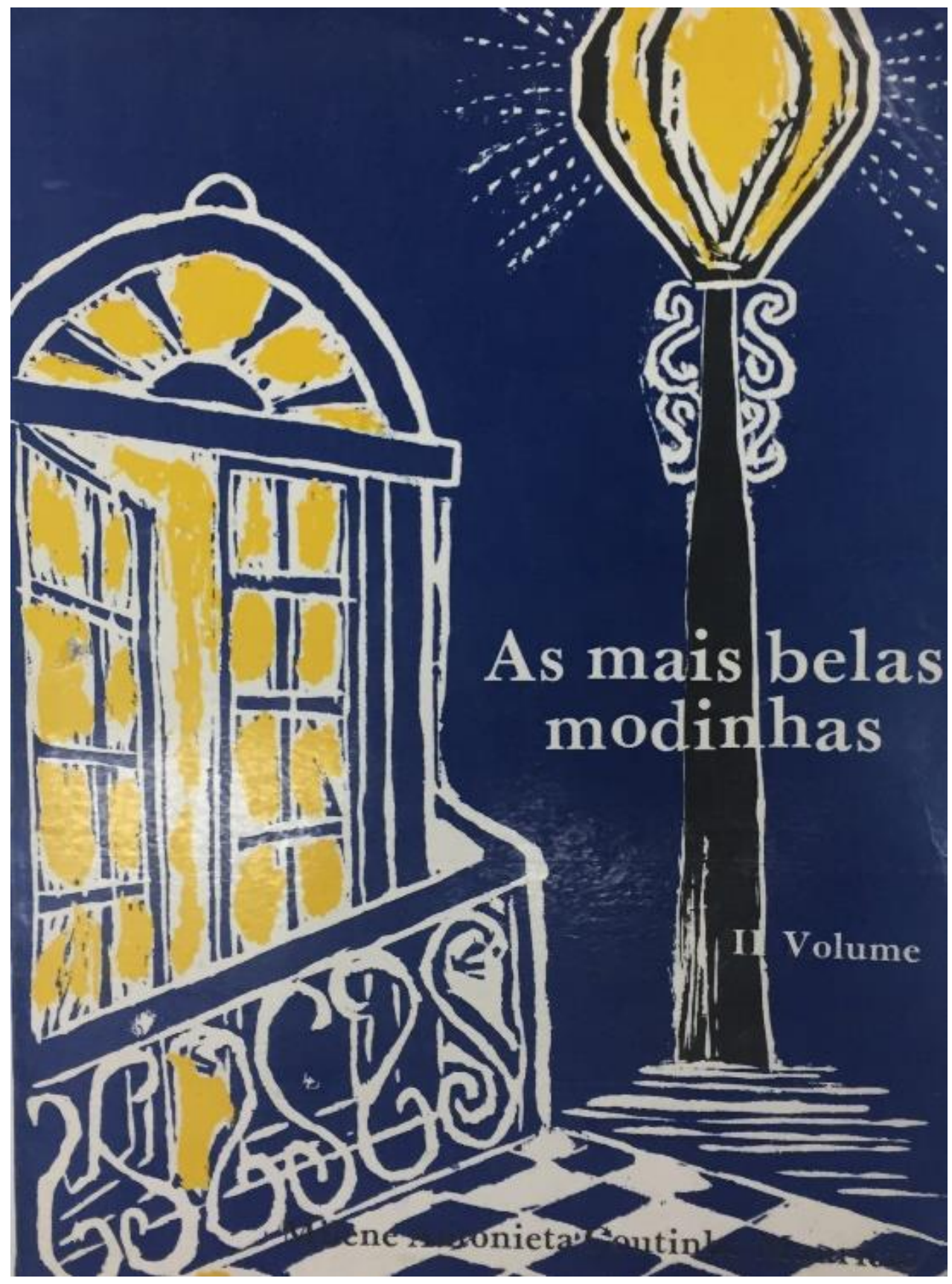

Fonte: As mais belas modinhas II volume 


\title{
PASTORINHAS
}

\section{Letra de João de Barros} Música de Noel Rosa

\author{
A Estrela d'Alva \\ No céu desponta \\ E a lua anda tonta \\ Com tamanho esplendor. \\ $\mathrm{E}$ as pastorinhas \\ Pra consolo da lua \\ Väo cantando na rua \\ Lindos versos de amor.
}

\section{Linda Pastora}

Morena da cor de Madalena

Tu năo tens pena de mim

Que vivo tonto com o teu olhar.

Linda criança

Tu não me sais da lembrança

Meu coraçăo não se cansa

De sempre e sempre te amar.

Fonte: As mais belas modinhas II volume 
Figura 5- Letra do choro Carinhoso

Meu coração,

Nāo sei porque,

Bate feliz,

Quando te vê...

E os meus olhos

Ficam sorrindo

E pelas ruas

Vāo te seguindo...

Mas mesmo assim

Foges de mim.

$\mathrm{Ai}$, se tu soubesses

Como eu sou tâo carinhoso

E muito, muito que te quero

E como é sincero, o meu amor

Eu sei que tu năo fugirias

Mais de mim.

Vem, vem, vem, vem

Vem sentir o calor

Dos lábios meus

A procura dos teus

Vem matar, esta paixăo

Que me devora o coraçåo

E sendo assim, entāo

Serei feliz, bem feliz... 
Espasiani observa ainda, que a delimitação feita por Mario de Andrade quando utilizou o complemento de salão, "usada como ele o fez, restringe o tipo de lugar, o tempo já especificado por ele, modinhas do tempo do Império, - bem como as pessoas que as cantariam e/ou ouviriam essa modinha". O uso do complemento de salão também indicaria a forma musical e a instrumentação. (ESPASIANI, 2016, p.42)

Concordamos que, de fato, o termo "de salão" pode indicar o espaço, o público, o tipo de repertório, os intérpretes, a instrumentação, até a performance, porém a ligação do termo com o tempo, no caso tempo do Império, seria reduzir a modinha de salão a apenas sessenta anos (1808-1822).

Espasiani, em sua dissertação Educação musical: leitura sobre os estudos sobre a modinha de salão carioca da primeira metade do século XIX, destacou que, durante o processo de transformação da modinha, seguindo a linha de Andrade, observa-se dois grupos sociais: a burguesia/aristocracia e o povo. Levantou uma reflexão sobre público e privado no fazer musical. O povo estaria em espaço externo (espaço público), ao sereno; e o primeiro grupo em espaço interno e privado (casa), no salão (ESPASIANI,2016).

A essa modinha produzida no espaço externo, ao sereno, deu-se o nome de modinha de seresta. O termo seresta é considerado sinônimo de serenata por Mário de Andrade. O verbete serenata foi explicado como "execução de trechos musicais, depois do anoitecer" (ANDRADE,1989, p.471). A palavra serenata provém da língua italiana, derivada do latim serenus. A partir do Classicismo o termo também foi utilizado para designar uma forma musical. Houaiss, no Dicionário da Língua Portuguesa, explica que seresta é a serenata brasileira (HOUAISS,2007, p.2553).

Como surgiu a modinha de seresta? A discussão retoma ao assunto origem da modinha, tratado no primeiro capítulo desse trabalho. Andrade afirma que a modinha saiu do meio erudito para o convívio do povo:

Nesse tempo a Modinha já ultrapassara as janelas abertas dos saraus burgueses; e por ventura colhida no ar dos "serenos" pelo povo, na fermentação deste elaborava as fórmulas e formas inconscientes que a haviam de nacionalizar com mais violência e dar algumas preciosidades ao populário (ANDRADE, 1980, p.9).

E Tinhorão afirma que a modinha, ao contrário do que pensou Mário de Andrade, era 
de origem popular e teria sido levada aos salões.

No Brasil, a consequência dessa eruditização da modinha e do próprio lundu (que em certas peças compostas ou harmonizadas por mestres contrapontistas quase não mais permitia diferenciar um género de outro) ia levar, a partir do século XIX, a uma curiosa evolução: a modinha e o lundu das partituras escritas por músicos de escola torna-se-iam peças de canto para salas burguesas... (TINHORÃO, 1990, p.94).

Para Tinhorão, coexistiram dois gêneros de cantigas populares até o século XIX. “As de ritmo mais vivo e melodia mais simples, no canto a solo dos seresteiros, pelas ruas; as mais elaboradas e harmonizadas no estilo bel'canto, nos salões." Observa-se que o ambiente era distinto, sinalizando que aconteciam em camadas sociais diferentes. Da fusão entre as duas, apareceria a modinha que se popularizou na virada do século XIX para o século XX como uma modinha mais sentimental. (TINHORÃO, 1990, p. 95)

Um dos objetivos desse estudo é observar a circulação das modinhas; para isso, é preciso identificar as modinhas dentro do repertório. Como identificar as modinhas? Como separá-las em modinha de salão e modinha de seresta? Para estudar as modinhas, observaremos seus espaços geográficos, costumes, intérpretes, instrumentações, temas, estruturas poéticas, formas musicais e construção melódica.

\subsection{Temática e estrutura poética}

A modinha tem, majoritariamente, letras com temáticas de amor. Mário de Andrade a descreveu como um suspiro de amor. A temática é comum para modinhas de salão podendo ser portuguesas, brasileiras ou luso-brasileiras e para as modinhas de seresta brasileiras.

Kiefer destaca que a modinha que predominou nos salões lisboetas no final do século XVIII "era uma canção essencialmente amorosa. Seus textos não constituíam propriamente um gênero literário específico" (KIEFER,1977, p.16)

Doderer pontua que as modinhas possuem em seus textos aspectos característicos como "desgostos de amor, saudades e cuidados à volta da pessoa amada". Expõe ainda que algumas vezes os textos estão escritos em cenas mitológicas, alegóricas ou bucólicas (DODERER, 1984, p.VII).

Independentemente da época em que foram compostas, em geral, as modinhas tratam sobre as dores do amor, e muito raramente, sobre as alegrias. Galvão em seu livro A modinha norte-rio grandense, enumerou algumas ocorrências dos temas das modinhas: "amor 
pretendido; amor não correspondido; amor ausente e saudade; o amor perdido" e, em poucos casos, o amor correspondido (GALVÃO, 2000, p.40).

$\mathrm{Na}$ nossa pesquisa, pudemos constatar as descrições elencadas acima em muitas obras. Destacamos alguns trechos nos exemplos abaixo:

-Desgostos de amor: trecho retirado da modinha Roseas flores d'álvorada (ANDRADE, 1980, p.32).

Não póde gosar venturas

Que de amor sofre aflição

Não póde afeito aos gemidos

Ter prazer meu coração

-Saudades: trecho retirado da modinha Recorda-te de mim (BRITO, 2013, p.50).

Recorda-te de mim quando cismares

Naquelas tardes de saudade finda

Quando a brisa brincava entre os palmares

Recorda-te de mim que te amo ainda.

-Cuidados à volta da pessoa amada: trecho retirado da modinha Em qualquer parte que esteja (LAFORGE, s/d, s/n).

Não vivo para os prazeres

Que tu não podes gozar

Vivo para ver te alegre

Vivo só para te amar.

-Amor pretendido: trecho retirado da modinha Esperança (SIQUEIRA, 1979, p.223).

De teus carinhos privado,

Sem ter um riso qualquer,

Minha esperança é um sonho

De ter-te um dia, mulher. 
-Amor não correspondido - trecho retirado da modinha Se não me amas ó mulher (MENDES, 1959, p.123).

Se não me ama ó mulher porque me prendes

Teu coração, tua vida é o meu viver

Para que zombas de quem te adora tanto

Para quem zombas ó mulher da minha dôr

-Amor ausente e saudade - trecho retirado da modinha Agonia (SALLES,2005, p.259).

Quão triste o viver

Longe da amada

E da namorada

$\mathrm{O}$ meu viver

Melhor que eu não a visse

Assim não sofreria,

Não quero, já disse,

Viver na agonia.

-Amor perdido - trecho retirado da modinha Se fores ao fim do mundo (LIMA,2001, p.131).

Se fores ao fim do mundo

Lá mesmo te ei de hir buscar

Em qualquer parte que estejas

Eu sem ti não posso estar

Outro tema recorrente é o culto à pessoa amada, que em geral, é representada pela figura feminina, como explicitado por Mário de Andrade.

Textos seguindo pacientemente o gosto (sic) das épocas, ora arcadianos, 
pastoreando Lilias, Marilias e Márcias, ora românticos (sic), suspirando por fadas, belas, ingratas, anjos e até "modernos cupidinhos" e mil outras delicadezas (ANDRADE, 1980, p. 6).

Apresentando o eu lírico masculino, a figura feminina é cantada em poemas e pode destacar aspectos físicos como as mãos, os olhos, o rosto, a palidez e psicológicos como a graça, a doçura, a pureza, a indiferença. O nome também é utilizado nas letras.

Às vezes anjo, às vezes demônio; idealizada e rebaixada; amada e esconjurada; santa e sensual; é nesse amálgama de desejos e ideais que a mulher do século XIX é retratada pelos românticos nas mais lânguidas modinhas, feitas para a donzela sonhar, divertir-se, refletir sobre o amor e se educar sentimentalmente (SILVA JUNIOR, 2008, p.114).

Nas modinhas, a figura feminina idealizada vivia uma realidade diferente da mulher comum. No poema, a mulher era valorizada, querida, amada e tinha poder sobre o homem apaixonado que faria tudo por ela. Fora do poema, a mulher vivia numa sociedade em que era subjugada e dominada. A idealização feita pelo eu lírico masculino coloca a figura feminina num pedestal e ele num lugar submisso, ocorrendo uma relação semelhante às que aconteciam nas Cantigas de Amor Trovadorescas ${ }^{19}$. Para alguns estudiosos, talvez essa seja a razão para tanta aceitação do gênero pelas moças e senhoras.

Para Silva Júnior, quando a mulher aparece de forma sensual perde o poder, é difamada, aproximando-se do que acontecia nas Cantigas Satíricas do Cancioneiro Medieval $^{20}$.

Também foram compostas modinhas utilizando o eu lírico feminino e a figura amada representada pela figura masculina. Como a produção de modinhas compostas por mulheres era muito pequena, alguns homens passaram a escrever como se fossem mulheres, utilizando o eu lírico feminino. Galvão, em sua coletânea, observou que quase a totalidade das composições eram feitas por homens poetas e músicos, destacando- alguns padres. Em sua pesquisa, registrou a participação de seis mulheres, dentre elas, Auta de Souza, poetisa brasileira, natural de Natal, da segunda geração romântica.

- Modinhas: eu lírico feminino

\footnotetext{
${ }^{19} \mathrm{O}$ ideal amoroso dessas cantigas, o amor cortês, é aquele que vive em constante sofrimento, porque não é correspondido. Demonstra submissão e fidelidade à mulher amada.

${ }^{20}$ As Cantigas Satíricas criticavam de forma irônica os costumes clericais, a decadência dos nobres e o adultério das damas.
} 
- trecho retirado da modinha Antes quizera lutar com as ondas (LAFORGE, s/d, $\mathrm{s} / \mathrm{n})$.

Antes quizera lutar com as ondas

Soffer revezes da calm'ardente

Do que oh Ceos! hum só instante

De ti meu bem viver auzente

Mas por decreto do cruel fado

Sofro calada, vivo contente

Pr'aque nenhum mortal conheça

O mal que meu peito sente.

- trecho retirado da modinha Astuciosos os homens são (LAFORGE, s/d, s/n).

Astuciosos os homens são

Enganadores por condição

Os homens querem sempre enganar

Nós nos devemos acautelar

Joaquim Manuel de Macedo inseriu partituras para moças e senhoras cantarem, nos exemplares do romance A Moreninha, com versos cantados pela personagem (SILVA JUNIOR, 2008).

Pierre Laforge, flautista e editor francês, que morou no Rio de Janeiro, foi um dos responsáveis pelo crescimento desse mercado de impressão. Iniciou esse ofício por volta de 1834. As partituras de modinhas eram destinadas às musicistas amadoras, em geral pianistas e amantes do bel canto.

Embora os temas das modinhas, em geral, sejam ligados ao amor, outro tema presente refere-se à natureza. Os sons da natureza como o canto dos pássaros, o vento, a água, são associados ao canto e destacam a harmonia que essa proximidade causa ao poeta. Convém observar que essa temática aparece mais nas modinhas cujos textos têm relação com o Arcadismo.

Texto da modinha $O$ Coração (SIQUEIRA, 1979, p.169). 
O coração é o colibri dourado

Das veigas puras do jardim do céu

$\mathrm{Um}$ - tem o mel da granadilha agreste,

Bebe o perfume que a boninha deu.

Outro- voa em ais virentes balsas

Pousa de um riso na rubente flor

Vive do mel - a que se chama - crenças,

Vive do aroma - que se diz - amor.

Os escritores árcades, em sua maioria, eram homens cultos. De origem social média ou alta, valorizavam a simplicidade. Suas obras estão ligadas ao pastoralismo, ao bucolismo, à exaltação da natureza. Acreditavam na brevidade do tempo e que a verdadeira felicidade estaria em aproveitar o que a vida oferecesse no presente, isto é, viver de forma simples e sem culpa, desprezando os valores materiais. Um representante clássico desse movimento é o poema Carpe Diem de Tomás Antonio Gonzaga que diz: “Ah! não, minha Marília, aproveitese o tempo, antes que faça o estrago de roubar ao corpo as forças, e ao semblante a graça!" (GONZAGA,1792, p.57).

Segundo Silva Junior, “Assim como a elementos naturais também é bastante comum encontrar nas letras de modinhas a ideia da música como aliança divina, ou melhor, como instrumento capaz de dialogar com Deus" (SILVA JUNIOR, 2008,p.119).

Para Lima, Caldas Barbosa utiliza em suas modinhas a temática do amor ideal e algumas vezes o amor sensual e erótico. O que, de certa forma, difere das características elencadas pela maior parte dos livros sobre modinhas. Textos que abordam amor sensual e erótico, em geral, são mais recorrentes nos lundus. Lima destaca que foi no poema Recado do volume I da Viola de Lereno que a palavra modinha apareceu pela primeira e única vez, como subtítulo. "Cantou algumas modinhas? E que modinhas cantou? Lembrou algumas das minhas? Não, não [...]" (LERENO,1798,s/n) ${ }^{21}$.

Galvão, em sua pesquisa, constatou que a forma mais comum das modinhas brasileiras, recolhidas no século XX, era a estrofe em quatro versos, contendo entre seis e onze sílabas. Constatou variados tipos de rimas e apenas um exemplar sem rima. Nessa coletânea, com 201 modinhas, ele apontou dois sonetos musicados, mas nenhum soneto alexandrino. Atribui o pouco uso de sonetos à dificuldade de acomodar a melodia nos

\footnotetext{
${ }^{21} \mathrm{O}$ livro não possui numeração de página. O poema é o número XV.
} 
quartetos e tercetos presentes no mesmo poema (GALVÃO,2000, p. 39).

Para Cascudo a modinha possui quadra com rimas intercaladas, o que denomina “típica modinha sentimental” (CASCUDO apud GALVÃO,2000, p.20).

A modinha esteve presente na literatura e nos jornais também, como demonstrado nas crônicas de João do Rio.

João do Rio, em 1905, escreveu a crônica A musa da ruas na revista Kosmos, no Rio de Janeiro. O cronista observa que a modinha tem início com toda a pompa dos salões, impressionando estrangeiros e destacando que os poetas "que sabiam ler", ou seja, homens da academia, passaram a escrever modinhas utilizando o "metro modinheiro"22.

Depois os poetas que sabiam ler continuaram a dar o seu prestígio às sibaríticas melodias que punham Lord Beckford em delírio e em deleite, e nós vemos toda a escola romântica tomar inconscientemente na maioria dos seus versos a feição melódica, o metro modinheiro; vemos aquele pernóstico elegante, o Magalhães dos Suspiros Poéticos, escrever em Roma versos que estão pedindo cavaquinho, gaforinha e unha grande; vemos Castro Alves criar para esse gênero canções de uma frescura eterna como a Tirana:

Minha Maria é bonita

Tão bonita assim não há

O beija-flor quando passa

Julga ver o manacá

Minha Maria é morena

Como as tardes de verão

Tem as tranças da palmeira

Quando sopra a viração (RIO, 2008, pp.234-252).

Convém ressaltar que João do Rio é pseudônimo de João Paulo Emílio Cristovão dos Santos Barreto, jornalista, cronista e teatrólogo, membro da Academia Brasileira de Letras.

A crônica A musa da ruas descreve o que o autor entende como percurso da modinha, que chama de musa, e sua derrocada. O texto, além de preconceituoso com a cultura popular e povos como os ciganos, faz a infeliz comparação do gênero musical com uma dama e sua desgraça moral. Destaca que a modinha, ou como ele denomina, a musa, saiu dos nobres salões acompanhada de intelectuais e poetas letrados, onde era respeitada e valorizada. Em seguida lamenta que a nobre dama tenha se acompanhado de repentistas e ciganos, cantadores de toda espécie, indo a a maus lugares. A musa urbana passou a cantar seus amores pelas esquinas, ficando mais popular e tendo encontros com bardos. $\mathrm{O}$ autor completa ainda que, nesse momento, a modinha transformou-se na vulgar musa de um milhão de indivíduos.

\footnotetext{
${ }^{22}$ Quando o autor cria o texto já pensando que será uma letra de música (uma letra de modinha).
} 
Observa que nessas modinhas há muitos "erros de gramática e de metrificação". Descreve ainda que a musa se apaixonou por poeta político e, por isso, até acabou com a má fama antiga. Finaliza alegando que a musa, agora, é como a alma da multidão e termina seu percurso tornando-se livre, pobre e vagabunda, mas ainda capaz de emocionar.

[...]A musa da cidade, a musa constante e anônima, que tange todas as cordas da vida e é como a alma da multidão, a musa triste é vagabunda, é livre, é pobre, é humilde. E por isso todos lhe sofrem a ingente fascinação, por isso a voz de um vagabundo, nas noites de luar, enche de lágrimas os olhos dos mais frios, por isso ninguém há que não a ame - flor de ideal nascida nas sarjetas, sonho perpétuo da cidade à margem da poesia, riso e lágrima, poesia da encantadora alma das ruas!... (RIO, 2008, pp.234-252).

Embora a crônica seja capaz de nomear intérpretes e importantes personagens da literatura, instrumentos, costumes, além de inserir exemplos de temáticas amorosas da época, ela é impregnada de juízos, conceitos implícitos, moralidade, e proteção ao grupo a que pertencia de poetas da Academia Brasileira de Letras.

Edilson de Lima destaca que os poemas de Caldas Barbosa se relacionam com a cultura popular e com a cultura árcade. "A forma preferida de Caldas Barbosa será a quadra em redondilha maior e menor com rima entre o segundo e quarto verso" que o aproxima da cultura popular e a rima utilizada adequa-se à cultura árcade (LIMA,2010, p.51)

Galvão observa que os seresteiros não eram bem vistos, mas dentre eles ainda existia uma diferença: os poetas tinham prevalência em relação aos músicos. $\mathrm{O}$ autor acredita que a possibilidade de publicar suas obras tenha sido determinante nessa hierarquia. Em Natal, no Rio Grande do Norte, como na maioria das cidades, o músico popular, em geral, não dominava a escrita musical, e mesmo que conseguisse escrever sua criação, não havia uma editora que a imprimisse. O poeta dispunha das Typographias. "Era destino do compositor ficar à sombra do poeta" (GALVÃO, 2000, p.38).

$\mathrm{Na}$ nossa pesquisa, pudemos observar que o número de obras com compositores desconhecidos é bem maior que o número de obras com poetas desconhecidos. No gráfico a seguir apresentamos uma coluna com número de compositores desconhecidos e outra com compositores declarados, em seguida apresentamos um gráfico dos poetas. 
Gráfico 1- Compositores

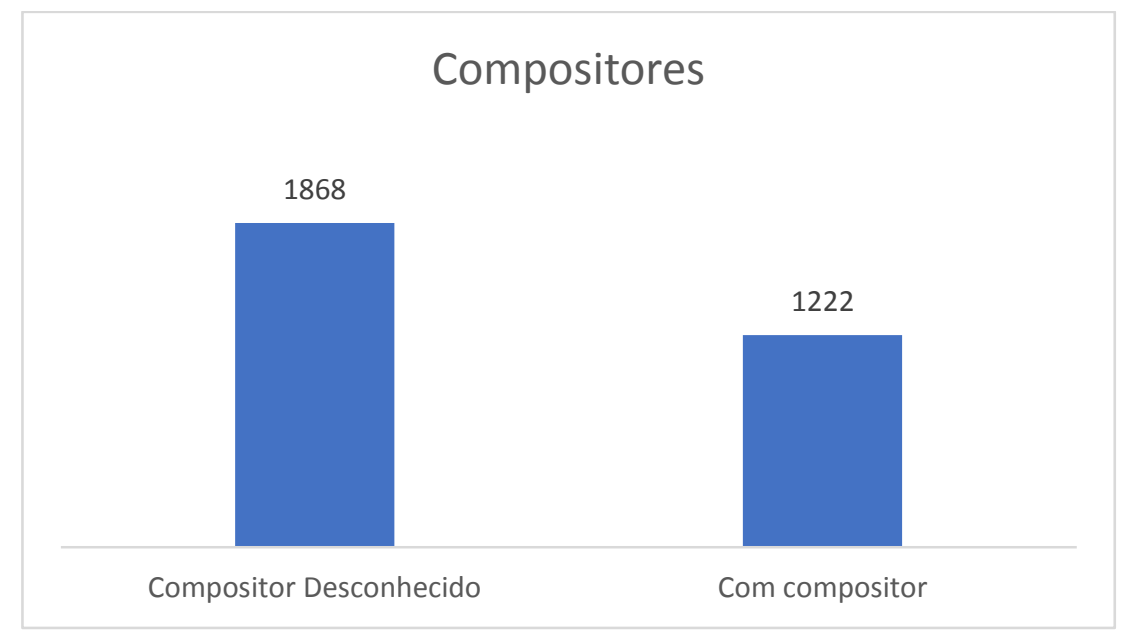

Fonte: Lista de modinhas

Gráfico 2- Poetas

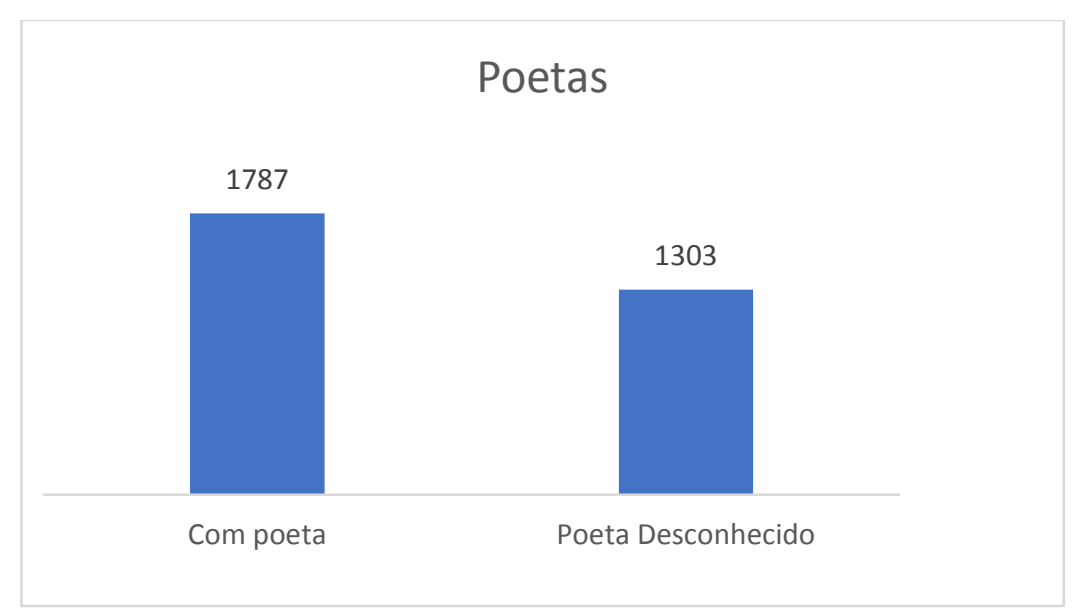

Fonte: Lista de modinhas

2.2 Elementos musicais: forma musical, métrica e modos

Abordaremos alguns elementos musicais presentes na construção das modinhas, para tanto utilizaremos como base as análises das coletâneas de Andrade (1980), Siqueira (1979), Galvão (2000), Mendes (1959) , Kiefer (1977) e Lima (2001) bem como relatos de viajantes e bibliografia referente às modinhas. 
Mário de Andrade destacou que algumas Modinhas Imperiais tomaram a forma da Ária setecentista e oitocentista e observou as seguintes construções:

A-B - (duas estrofes)

A-B-C - (duas estrofes e refrão)

A-C - (estrofe e refrão)

A-B-D - (duas estrofes e um stretto que faz as vezes de um refrão)

Observou ainda que existem modinhas escritas como uma Ária da Capo, forma ternária muita usada no Barroco e que se caracteriza pela repetição da parte $\mathrm{A}$, com alterações na melodia, após a execução da parte B.

A-B-A - (duas estrofes, sendo o A da repetição ornamentado e/ou alterado)

Kiefer observou que as modinhas possuem predominância dos seguintes esquemas formais:

- AABB (versos 1 e 2 com parte melódica A e versos 3 e 4 com parte melódica B)

- AABB-C (duas estrofes diferentes com repetição e refrão)

Para Siqueira, as modinhas são estróficas, consideradas formas estáveis, sob o olhar musical. Porém observa que podem ser diferenciadas historicamente em três tipos. "Temos o tipo ancestral que é o bárdico, o tipo evolutivo que é o árcade e, finalmente, o estrófico, que conglomera os demais" (SIQUEIRA, 1979, p.112).

Estrutura formal da Modinha Bárdica

A-I-A-I-A-I-A (Estrofe, Interlúdio, Estrofe, Interlúdio, Estrofe)

A estrofe se mantém e o Interlúdio contrasta variando.

Estrutura formal da Modinha Árcade

Variada

A-B (duas estrofes com ampliação)

A-B-C (duas estrofes e um estribilho)

Estrutura Formal da Modinha Estrófica 
A-B (duas estrofes)

A-B-C (duas estrofes e um estribilho)

A-B-D (duas estrofes e um trio ${ }^{23}$ em movimento acelerado)

A-B-I-A-B-I-A-B (Introdução, $1^{\mathrm{a}}$ estrofe, $2^{\mathrm{a}}$ estrofe, Interlúdio, $1^{\mathrm{a}}$ estrofe, $2^{\mathrm{a}}$ estrofe, coda)

Lima observou nas suas análises que as modinhas contidas no manuscrito da Ajuda apresentavam quatro tipos formais:

Forma Simples

A (uma estrofe)

Forma Binária

A-B (duas estrofes)

A-B-Coda (duas estrofes e coda)

Forma Ternária

A-B-A' (duas estrofes e uma repetição com variação)

A-B-A-coda ( duas estrofes com repetição sem variação e coda)

Forma livre

Uso de contraponto

Sem repetição de frases

Eunice Mendes coletou 32 documentos musicais na Separata Contribuição para o estudo da modinha. Constatou o uso as seguintes formas:
A-B (duas estrofes)
A-C (estrofe e refrão)

Galvão, em sua coletânea, destaca que, em algumas modinhas a melodia se repete na estrofe seguinte com presença de interlúdio (A-I-A); e, raramente, apresenta uma segunda

\footnotetext{
${ }^{23}$ Mário de Andrade chamou de Stretto, que Siqueira julgou inadequado por ser uma técnica contrapontística aplicada à fuga clássica e que, para ele, não condizia com a construção das modinhas.
} 
estrofe diferente da primeira (A-B). Não foram encontradas modinhas com duas partes e um refrão (A-B-C) (GALVÃO, 2000,p.44).

Esquema formal encontrado na coletânea de Galvão:

A-I-A (estrofe, interlúdio, estrofe)

A-B (duas estrofes)

Em nossa pesquisa não foi possível observar qual o esquema formal mais utilizado; porém, é nítido o uso variado sendo que as modinhas do século XX se aproximam dos esquemas formais das canções com maior presença do refrão.

Sob o ponto de vista da métrica, é possível encontrar modinhas escritas em compasso binário (simples e composto), ternário e quaternário.

Mário de Andrade destaca que as mais antigas são predominantemente binárias ou quaternárias e "as influenciadas pelo Cantabile italiano e pela Valsa", no período da decadência das modinhas de salão, utilizam o binário composto ou o ternário. Essa "decadência das modinhas de salão" que Andrade cita ocorre na virada do século XIX para o XX e coincide com o crescimento da modinha de seresta (ANDRADE, 1980, p.9).

Na coletânea feita por Mário de Andrade observa-se a seguinte construção:

$$
\begin{aligned}
& \text { Binário simples }-2 \\
& \text { Binário composto }-1 \\
& \text { Ternário simples }-3 \\
& \text { Quaternário simples }-8
\end{aligned}
$$

Bruno Kiefer destaca que predominam os compassos quaternários seguindo os ternários e algumas vezes encontra-se mudança de compasso na modinha (KIEFER, 1977, p.24).

Lima constatou que a maioria das obras da coleção da Ajuda está escrita em compasso binário totalizando vinte e três, duas estão em compasso binário composto, três em ternário simples e uma em quaternário. Ele observou que uma obra começa em binário simples e termina em ternário composto. 
Binário simples - 23
Binário composto -2
Ternário simples - 3
Quaternário simples -1

Mendes observou que dos trinta e dois documentos, vinte e dois foram escritos em compasso ternário simples e dez em compasso binário simples.

Binário simples -10

Ternário simples - 22

Siqueira coletou cerca de cento e nove modinhas e chegou à seguinte conclusão:

[...]observamos que a generalidade das modinhas é feita em compasso binário e quaternário (sejam simples ou compostos) bem como em tom menor. Os exemplares que existem em tom maior e em compasso ternário formam antes, exceções que não chegam a constituir regra[...] (SIQUEIRA, 1979, p.40).

Galvão, em sua coletânea, observou que, duzentas e vinte e seis modinhas são em compasso quaternário e cento e vinte e nove são em compasso ternário. $\mathrm{O}$ autor não citou as modinhas em compasso binário; porém, observando o livro, constatamos que tem dez modinhas em compasso binário, sendo cinco em binário simples e cinco em binário composto.

\footnotetext{
Binário simples -5

Binário composto -5

Ternário simples - 129

Quaternário simples - 226
}

Não foi possível determinar uma predominância na métrica das modinhas nessas coletâneas destacadas. A incidência da fórmula de compasso muda de acordo com o local e a época das composições.

Observando as análises dessas coletâneas percebemos que existe maior incidência de compasso binário nas Modinhas do Brasil, coletânea analisada por Lima, e essas seriam as mais antigas catalogadas. As Modinhas de Salão analisadas por Mário apresentam maior 
incidência de compasso quaternário. As Modinhas presentes na coletânea organizada por Mendes possuem maior incidência no compasso ternário. Galvão e Kiefer observaram maior incidência de compassos quaternários e Siqueira destaca binários e quaternários como maior incidência nas modinhas que recolheu.

Observamos, ao longo da pesquisa, que a troca de fórmula de compasso é um recurso utilizado, não amplamente; mas acontece como, por exemplo, na modinha Se o pranto apreciares, que tem na primeira parte um compasso quaternário e na segunda um compasso ternário. 
Figura 6- Primeira página da partitura da modinha Se o pranto apreciares

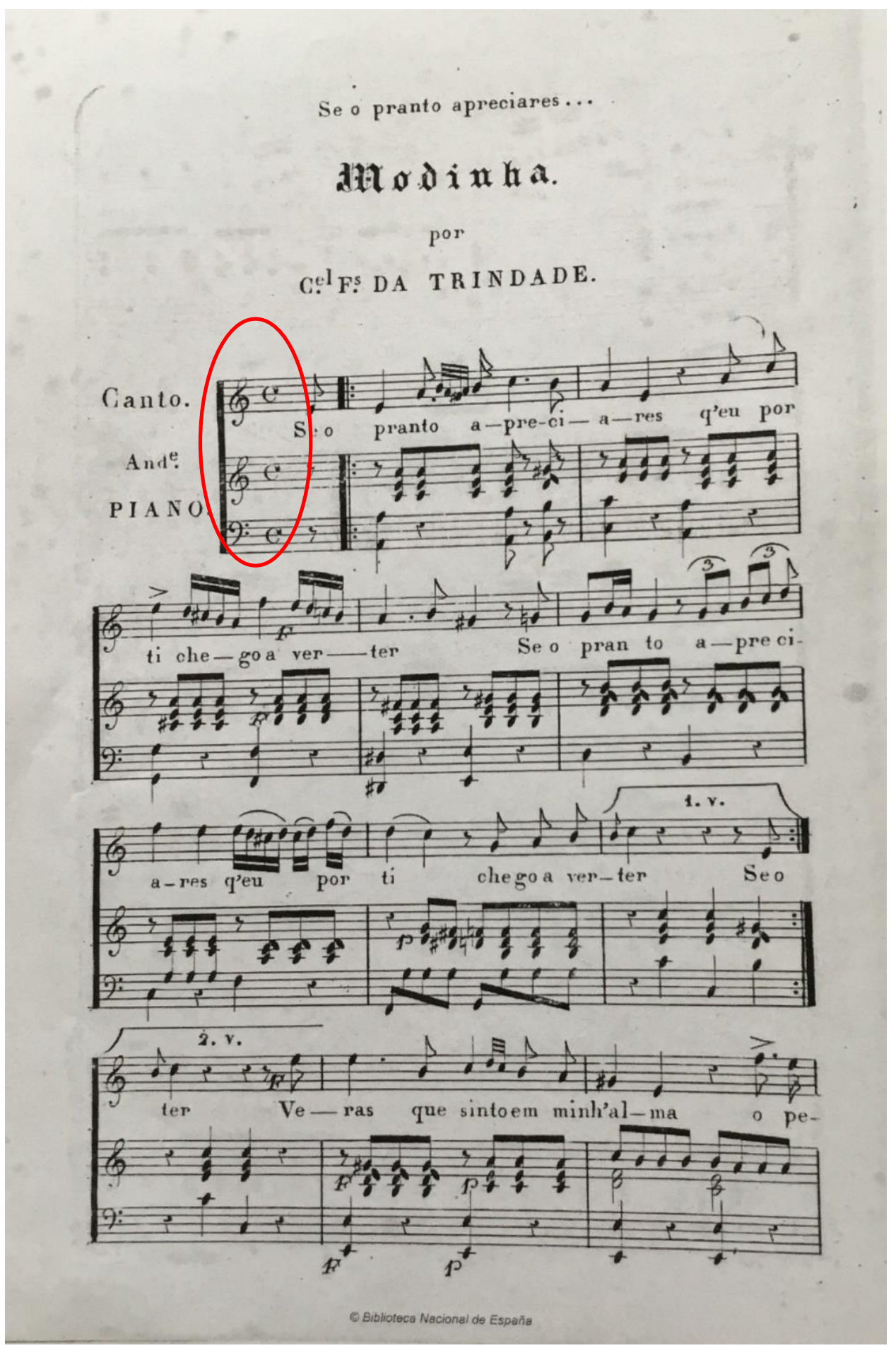

Fonte: Collecção de Modinhas Brazileiras 
Figura 7- Segunda página da partitura da modinha Se o Pranto apreciares

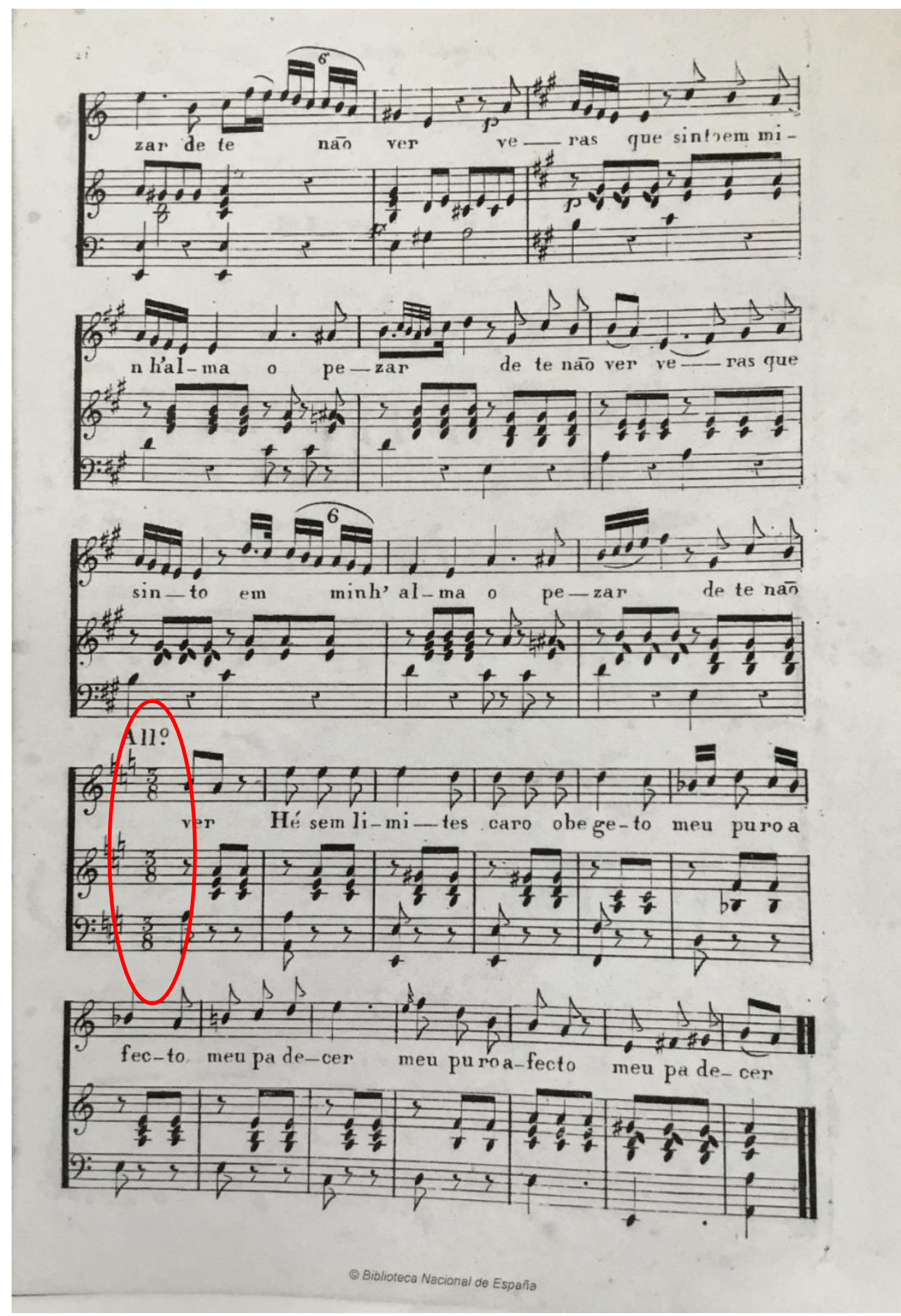

Fonte: Collecção de Modinhas Brazileiras

Outras práticas pouco comuns nas modinhas de salão são a inserção de introduções e finalizações instrumentais como na modinha Último adeus de amor, conforme trechos da partitura abaixo. Essa prática recorrente nas modinhas de seresta, com introduções e 
interlúdios não foram registradas em partituras, mas é possível ouvir em gravações como $A$ casinha bonitinha, gravada por Mário Pinheiro, ODEON, com documento 108191, em 76rpm disponível para escuta no acervo do IMS, http://acervo.ims.com.br/player/SophiaSLPlayer.asp acesso em 20.02.2019.

Figura 8- Trecho inicial da modinha Último adeus de amor

40

\section{Ultimo Adeus de Amor.}

V $0 \mathrm{Z}$
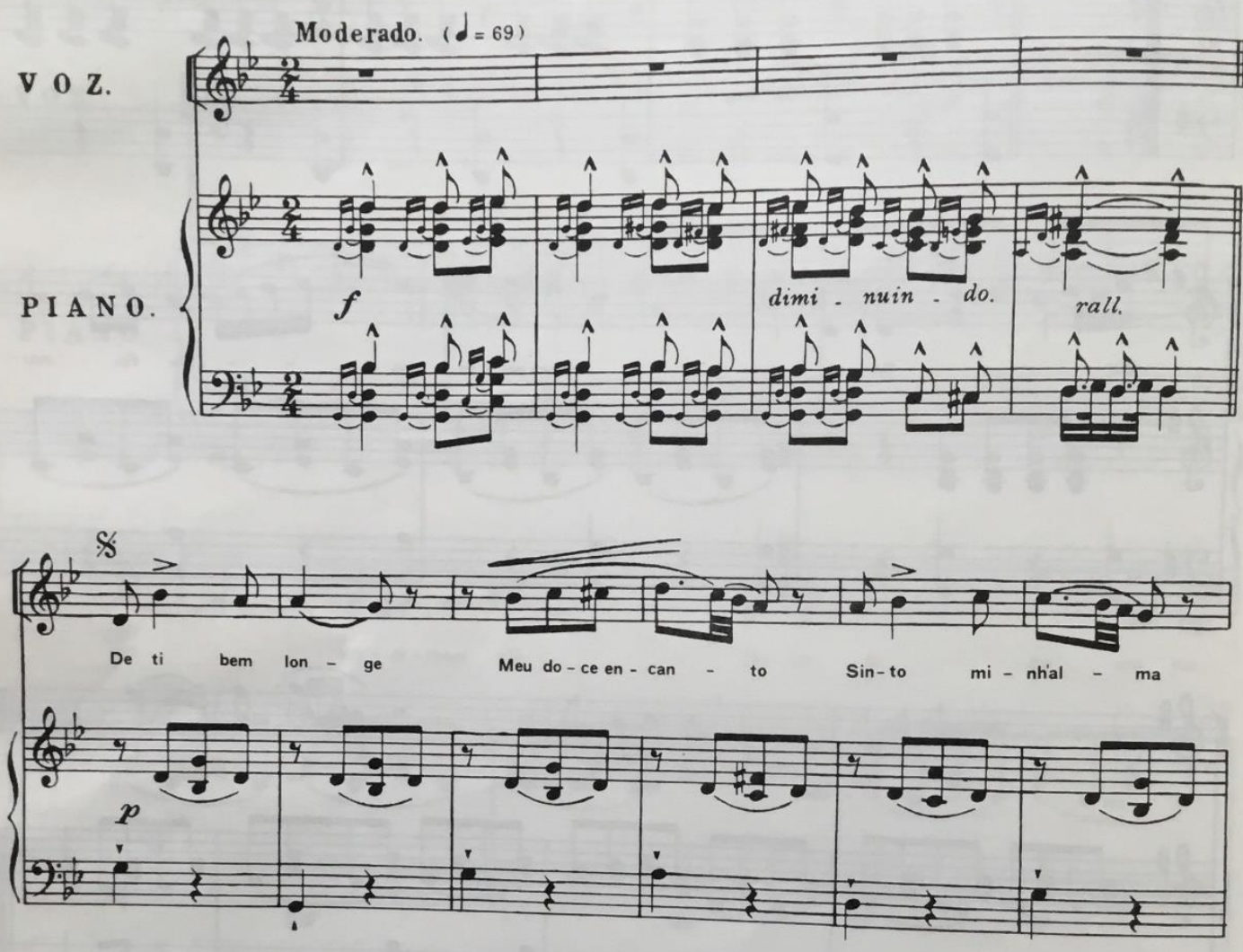
Fonte: Modinhas Imperiais

Figura 9- Trecho final da modinha Último adeus de amor

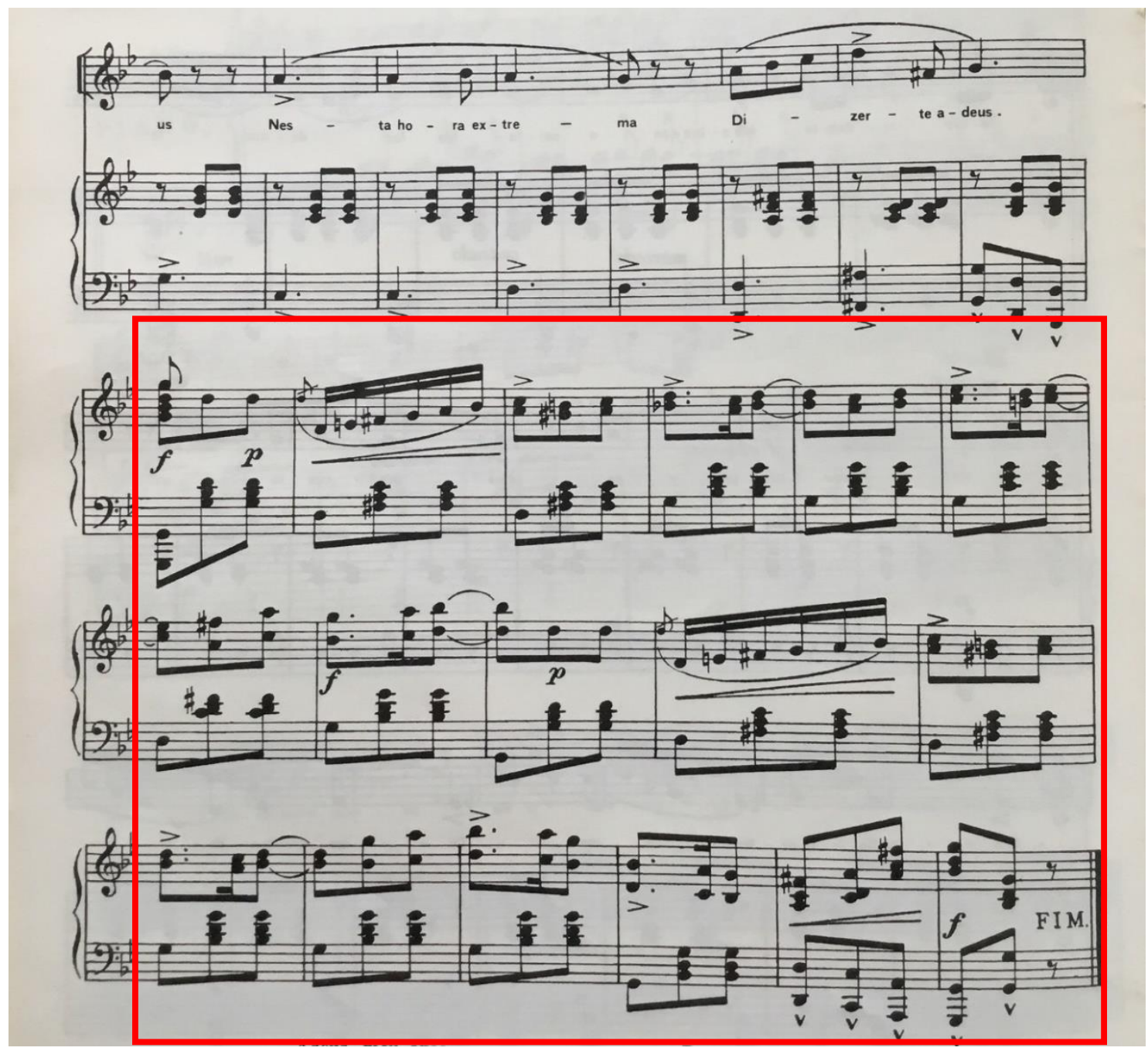


Sobre as tonalidades, Kiefer observou que, as tonalidades presentes nas modinhas por ele coletadas e analisadas, existem em similar quantidade no modo menor e no modo maior. (KIEFER, 1977, p.24)

Andrade também observou que há certa preferência pelo menor; e que, em alguns casos a modinha, embora inicie na tonalidade maior, termina na menor (ANDRADE, 1980, p. $10)$.

Para Siqueira, a maior parte das modinhas que recolheu é em tonalidade menor, sendo as de tonalidade maior consideradas exceções. Atribuiu essa preferência à religiosidade do povo e ao fato do modo jônio, correspondente ao modo maior, ser considerado lascivo pela Igreja Católica (SIQUEIRA, 1979, p.53).

Lima expôs que, das 30 modinhas presentes no manuscrito, 15 estão em tonalidade menor e 15 em maior.

Galvão observou que, em sua coletânea, existe maior incidência de modinhas na tonalidade menor. As menores totalizam 255 modinhas e as maiores com total de 143 (GALVÃO, 2000, p.48)

Embora Mendes ressalte que, em geral, as modinhas são menores, na sua coletânea existe maior incidência de modinhas na tonalidade maior, ao todo 19, enquanto as menores são em menor número com total de 16. (MENDES, 1959, p.152)

Nessas coletâneas destacadas não existe um consenso sobre um modo recorrente. Como pudemos perceber, as modinhas são compostas nos dois modos, embora a maior parte dos escritores relate que elas são, majoritariamente, em tonalidade menor.

Pudemos perceber em algumas modinhas a mudança de tonalidade de uma parte para outra. Na modinha, já exemplificada acima, Se o pranto apreciares além da troca de fórmula de compasso a modinha apresenta troca de tonalidade também, conforme destacado na partitura a seguir: 
Se o pranto apreciares...

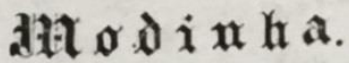

\author{
por \\ C. ${ }^{\mathrm{l}} \mathrm{F}$. DA TRINDADE.
}

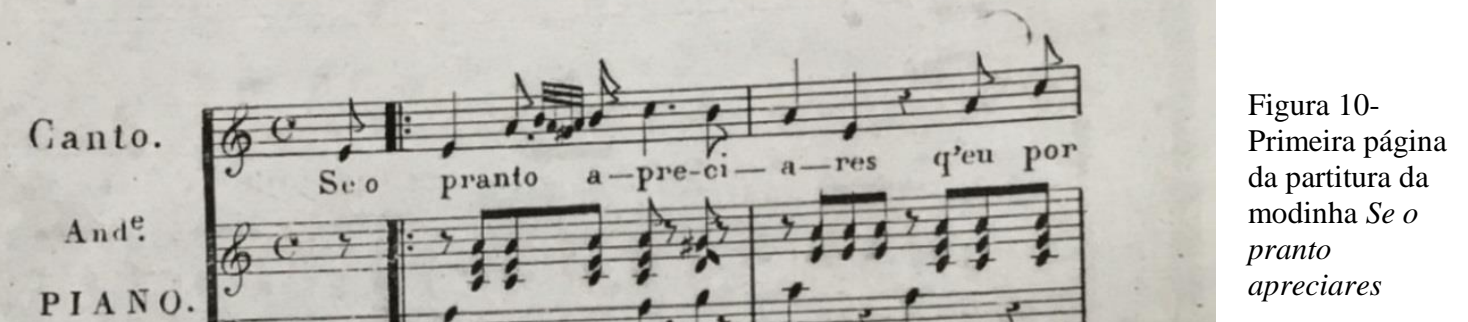




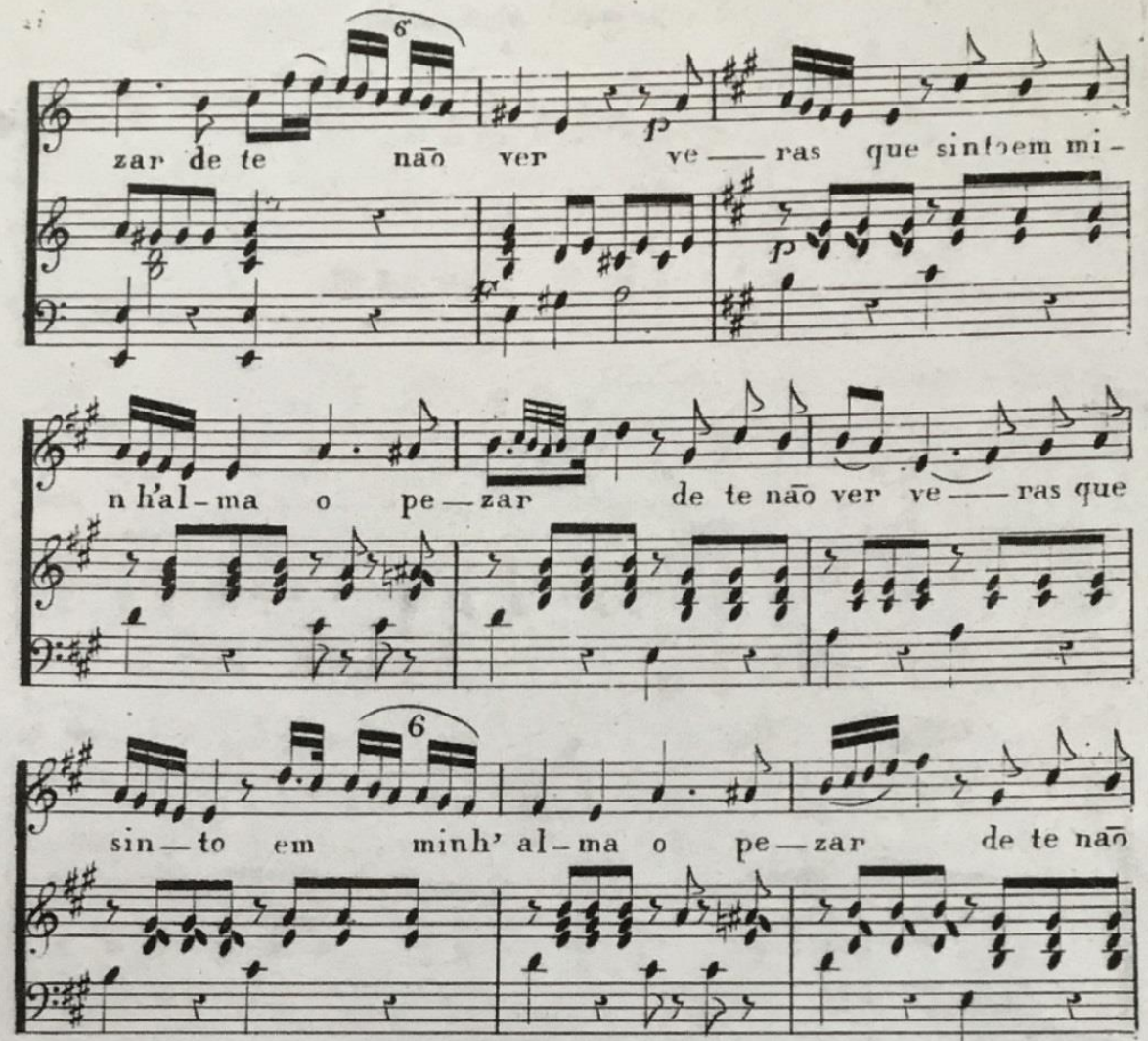

Fonte:

Collecç

ão de

Modinh

as

Brazile

iras

Figura

11-

Segunda

página

da

partitura

da

modinha

Se o

pranto

apreciar

es meu puroa-fecto meu pade-cer

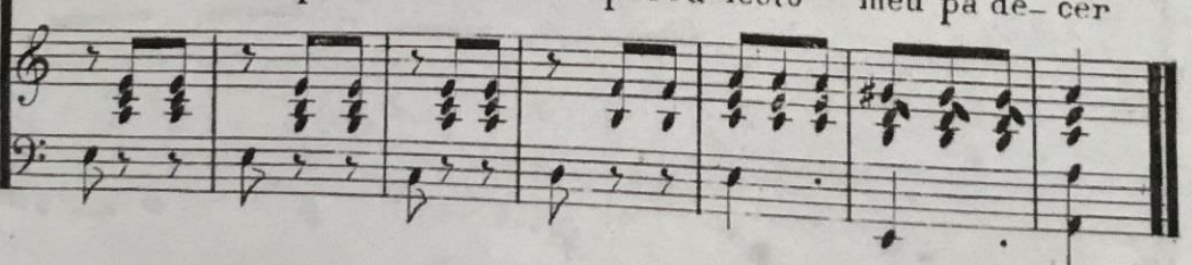


Fonte: Collecção de Modinhas Brazileiras

2.3 Instrumentação

Para compreender o cenário musical das modinhas foi preciso elencar alguns dados 
dos relatos dos viajantes sobre o fazer musical e agrupar as informações provenientes dos livros e capítulos dedicados à modinha. Pacheco em sua tese de doutorado adverte que "não podemos perder de vista que o julgamento de valor dos viajantes é eurocêntrico". (PACHECO, 2009, p.26)

Acreditamos que não só os relatos dos viajantes, mas também os primeiros estudos sobre a modinha foram escritos com base na musicologia europeia, ou seja, musicologia feita a partir do referencial do saber erudito europeu. Nosso objetivo não é admitir como verdade o juízo de valor presente nos relatos ou nos primeiros estudos, mas utilizar essa informação para compor um cenário musical e refletir sobre práticas interpretativas.

Algumas questões norteiam a construção desse cenário. Quais instrumentos utilizados? Quem são os músicos instrumentistas? Quem são os cantores? Para quem a modinha foi produzida? Quem a apreciava? Quem são os compositores? Fizemos um levantamento de várias afirmações decorrentes de estudos e pesquisas sobre o cenário musical da modinha, abordaremos e comentaremos abaixo.

De acordo com Castagna ${ }^{24}$, a maior parte das modinhas impressas no Jornal de Modinhas, periódico publicado em Lisboa entre 1792 e 1796, era composta de músicas para dois cantores e acompanhamento instrumental. As composições para voz solo ou para três cantores apareciam em menor número. O acompanhamento, em geral, era para cravo. "Em casos mais raros aparecem acompanhamentos para os seguintes instrumentos: viola; violino; guitarra (portuguesa); duas guitarras; duas guitarras e viola; duas guitarras, viola e baixo; cravo e dois bandolins; dois bandolins e baixo" (CASTAGNA,2003, p.6).

Segundo relato do Embaixador da Inglaterra, Lord Beckford, que esteve em Lisboa, em 1787, quando a noite chegava, segundo ele:

[...] metade da família se encontrava ocupada em entoar litanias de santos; a outra metade em caprichos e folganças de natureza talvez não muito edificante: o stacato monótono da viola (guitar) acompanhado pelo murmúrio tênue e suave das vozes femininas cantando modinhas, formava, em conjunto, uma combinação de sons estranha e não desagradável (ARAÚJO, 1963, p.41).

Para Tinhorão, o destacado citado pelo Lord Beckford, se aproxima mais do popular ponteio, tocando os pontos, ou seja, apertando os dedos sobre os pontos ou trastes criando uma valorização rítmica que não era muito comum, uma vez que, nessa época, a construção melódica era mais reconhecida. (TINHORÃO, 1990)

O manuscrito Modinhas do Brazil, da Biblioteca da Ajuda em Lisboa, é um dos mais

\footnotetext{
${ }^{24}$ O musicólogo Paulo Castagna é docente e pesquisador na Universidade Estadual Paulista Júlio de Mesquita Filho (UNESP).
} 
antigos documentos do gênero e nele é possível observar a escrita para dois sopranos e baixo contínuo. Segundo Lima, "Algumas modinhas trazem acompanhamento claramente escrito para violão ou viola de arame, ambos instrumentos muito usados no século XVIII, tanto em Portugal como na colônia brasileira" (LIMA, 2001, p.18).

De acordo com Araújo, as duas modinhas incluídas no Método de Viola de Manoel da Paixão Ribeiro, editado em 1789, em Coimbra, também foram escritas para duas vozes e acompanhamento de viola, nesse caso, viola de doze cordas ${ }^{25}$ (ARAUJO, 1963).

Viajantes como Grigóry Ivanovitch Langsdorff, que foi Cônsul da Rússia no Brasil em 1806 e Carl Friedrich Philipp von Martius, pesquisador austríaco, que veio realizar levantamento botânico e mineralógico em 1818, relataram o uso da viola como instrumento acompanhador do canto nas terras brasileiras. Porém, não se sabe ao certo qual instrumento de corda era esse que eles denominaram viola e se tinha corda simples ou dupla.

O Cônsul da Rússia, quando esteve no Brasil, registrou a música que ouviu na Vila de Nossa Senhora do Desterro da Ilha de Santa Catarina, em 1806, com o nome de Ária Brasileira $^{26}$.

[...] À noite as pessoas se encontram em pequenos grupos de familiares, onde se dança, brinca, ri, canta-se e contam-se anedotas, conforme a tradição portuguesa. Os instrumentos musicais mais usados são a viola e o chocalho. A música é cheia de expressão, terna e sentimental. As canções são de conteúdo modesto, frequentemente reiterando temas como amor por mulheres, corações sangrentos e feridos, desejos e saudades. [...] (LANGSDORFF,1818, pp.54-55 apud CASTAGNA, 2003,p.8).

Segundo o pesquisador austríaco Martius, a viola era a protagonista e ele observa ainda "é aqui a viola, tanto quanto no sul da Europa, o instrumento favorito" ( MARTIUS, 1981, p.110).

Para Vilela, a viola figurou como principal acompanhante do canto durante os três primeiros séculos de colonização. Em seguida dividindo e finalmente cedendo lugar ao violão, que "[...] pela afinação e por ter cordas simples e não duplas, mostrou-se mais funcional ao ofício[...]" (VILELA, 2013, p.41).

Kieffer observa que, em geral, os viajantes denominavam de guitarra os representantes dos instrumentos de cordas dedilhadas aqui presentes. Essa denominação incluía a viola de

\footnotetext{
${ }^{25}$ Embora com doze cordas, a viola era de cinco ordens, sendo três pares de cordas duplas e dois pares de cordas triplas.

${ }^{26}$ Brasiliaansche Aria, em holandês e Brasilische Arie, em alemão.
} 
arame, a guitarra romântica (ancestral do violão) e a guitarra portuguesa. O piano só se estabeleceria com mais força a partir da década de 30 do século XIX. (KIEFFER,1996, p.140).

O peregrino Nuno Marques Pereira, em visita a Salvador, no início do século XVIII, relata a presença do organo, do cravo e do monacórdio. Sabe-se que, posteriormente, o cravo foi perdendo espaço para o piano (PEREIRA in TINHORÃO, 1990, p.292).

Castagna observa que a partir da segunda metade do século XVIII a música profana no Brasil era composta de cantatas, óperas, danças luso-brasileiras e "a partir da década de 1790, a modinha e o lundu, com acompanhamento de violas e guitarras" (CASTAGNA,2003, p.3).

$\mathrm{Na}$ literatura, é possível encontrar referências aos instrumentos acompanhantes do canto como em Memórias de um Sargento de Milícias, escrito em 1852, por Manuel Antônio de Almeida, que cita a viola e a guitarra. Em Crônica dos Tempos Coloniais, escrito em 1875, por José Velho da Silva, o autor destaca a viola, a guitarra e o cravo. Em A Moreninha, escrito por Joaquim Manuel de Macedo, em 1843, são evidenciados o piano e a viola.

No final do séc. XVIII, algumas modinhas foram escritas com o objetivo de ser uma canção de sala para uma voz, acompanhada ao piano. Observa-se uma clara adaptação da ópera ao idioma local (Brasil e Portugal) e às particularidades da música de salão. Andrade observa que esse fenômeno "é uma mistura de plágios, adaptações, invenções e influência de toda casta" (ANDRADE, 1980); (DODERER, 1984). Denominada modinha "de salão", ela teve grande aceitação em Portugal e no Brasil. Em geral, esse tipo de modinha tem escrita para uma voz e acompanhamento para piano. É uma música de câmara com linhas melódicas semelhantes às árias de ópera.

Segundo Siqueira as modinhas de salão se difundiram a partir da segunda metade do século XVIII no Brasil e em Portugal, com partituras impressas e eram executadas por músicos que dominavam a escrita e a leitura. Entretanto, relatos como o de Grigóry Ivanovitch Langsdorff (1774-1852), Cônsul da Rússia no Brasil e do francês Ferdinand Denis, no início do século XIX, testemunham que, pelo menos, desde 1818, existia também uma música simples, cantada na rua, com expressão e conteúdo modesto, aproximando-se da classificação de modinha de seresta, dada por Siqueira.

O escritor Ferdinand Denis, em 1826, relatou que

[...] Ao mesmo tempo que a música de Rossini é admirada nos salões, porque é cantada com uma expressão que nem sempre se encontra na Europa, os simples arte sãos percorrem ao serão as ruas cantando essas 
encantadoras modinhas, que é impossível ouvir sem com elas se ficar vivamente comovido; quase sempre servem para pintar os devaneios do amor, as suas penas ou a sua esperança; as palavras são simples, os acordes repetem-se de uma forma bastante monótona; mas têm, por vezes, um tal encanto na melodia, e por vezes uma tal originalidade que o europeu acabado de chegar não pode cansar-se de as ouvir e compreende a indolência melancólica desses bons cidadãos que ouvem durante horas seguidas as mesmas canções (DENIS, 1826,pp.581-582, apud CASTAGNA, 2003, p.10).

As modinhas de seresta provavelmente aconteciam desde o século XVIII, porém a documentação é escassa, e o que se encontra com mais frequência são registros de músicas do século XIX em diante. Eram cantadas na rua sob o luar, sem uso de partitura impressa.

Os relatos das modinhas de seresta pelos estados brasileiros foram registrados de norte a sul e destacam o uso do violão como instrumento acompanhador nessa época. "Os livros de ficção do Ceará fazem referência à modinha, ou ao hábito das serenatas e cantorias nas festas com violão, cachaça e aluá" (ALENCAR, 1967, p.34).

Segundo Galvão, os poetas e músicos seresteiros não eram socialmente bem vistos. Conhecidos como pândegos, bebiam em excesso e sua vida desregrada, muitas vezes, tinha como consequência a debilidade orgânica e muitos foram acometidos pela tuberculose. Essa conduta foi motivo de reclamação no jornal República de 19 de janeiro de 1909.

Várias -Pedem-nos chamar a atenção do Sr. Capitão João Fernandes de Almeida, delegado de polícia do Bairro Baixo, para um bando de serenistas que vagueiam quase todas as noites, de violão ao peito, cantarolando modinhas e lundus os mais rebarbativos possíveis, ofendendo assim o pudor público.

Ainda anteontem, esses noctívagos praticaram as maiores insolências em algumas ruas da Ribeira, com a agravante de fazerem estação nas portas das casas de família.

Cumpre, portanto, à polícia, tomar as providências (REPÙBLICA in GALVÃO, p.37).

Espasiani, questiona a separação de estrato social nas práticas musicais observando que "a modinha aparece como um gênero de canção que, de alguma maneira, promove uma ligação entre as classes e suas diferentes formas de fazer música" (ESPASIANI, 2106, p.55).

No capítulo A modinha de salão e seu percurso nas diversas classes sociais expõe documentos e reflexões sobre a condição social dos músicos, sua importância dentro da sociedade, das subserviência e insegurança nas relações de trabalho enfrentados pelo músico profissional, em geral, negro ou pardo. De um lado, observa que os músicos presentes nas 
serestas são os mesmos que trabalham nos salões. Por outro lado, expõe relatos descritivos do músico amador, em geral, da aristocracia, que se diverte tocando ou cantando ao lado de profissionais para seleto público. (ESPASIANI,2016).

Com base no levantamento feito por Espasiani é possível compreender a dinâmica do fazer musical onde aconteciam as modinhas de salão no Brasil no século XVIII. Por um lado, o músico tocava nos salões as obras compostas por compositores da academia ou por músicos amadores que faziam parte do grupo social que promovia o salão; mas, em geral, esse profissional não pertencia a esse grupo social. Debret descreve essa dinâmica em Viagem Pitoresca e Histórica ao Brasil,

\begin{abstract}
Estranha-se entretanto, que os brasileiros, apaixonados pela música, conservem certo desprezo pelos músicos de profissão, a ponto de um homem rico, que paga generosamente a lição de seu professor, se mostrar intimamente envergonhado de sua amizade. Não porque não sejam os músicos, em geral dignos de estima, mas porque são pobres e num povo de comerciantes isso constitui um grave defeito. Deve-se entretanto excetuar a boa sociedade da capital que acolhe com afabilidade e trata com distinção os virtuoses de todas as províncias que aí vêm exibir o seu talento (DEBRET,1978, p.114).
\end{abstract}

Nas coletâneas que catalogamos encontramos os seguintes meios de expressão por obra.

Os registros das músicas, nessas coletâneas, estão organizados da seguinte maneira: das 3090 obras presentes na tabela, existe uma grande quantidade de letras de músicas; segundo a nossa pesquisa, totalizam 1763 obras. Em seguida, as linhas melódicas com letras ajustadas à partitura ou separadas, com cifras e sem cifras, totalizando 1049 obras. As partituras com escrita para voz e instrumento totalizam 277, sendo que dessas, 205 são para voz e piano e uma partitura para coro misto e piano, conforme gráfico apresentado abaixo:

Gráfico 3- Meios de expressão 


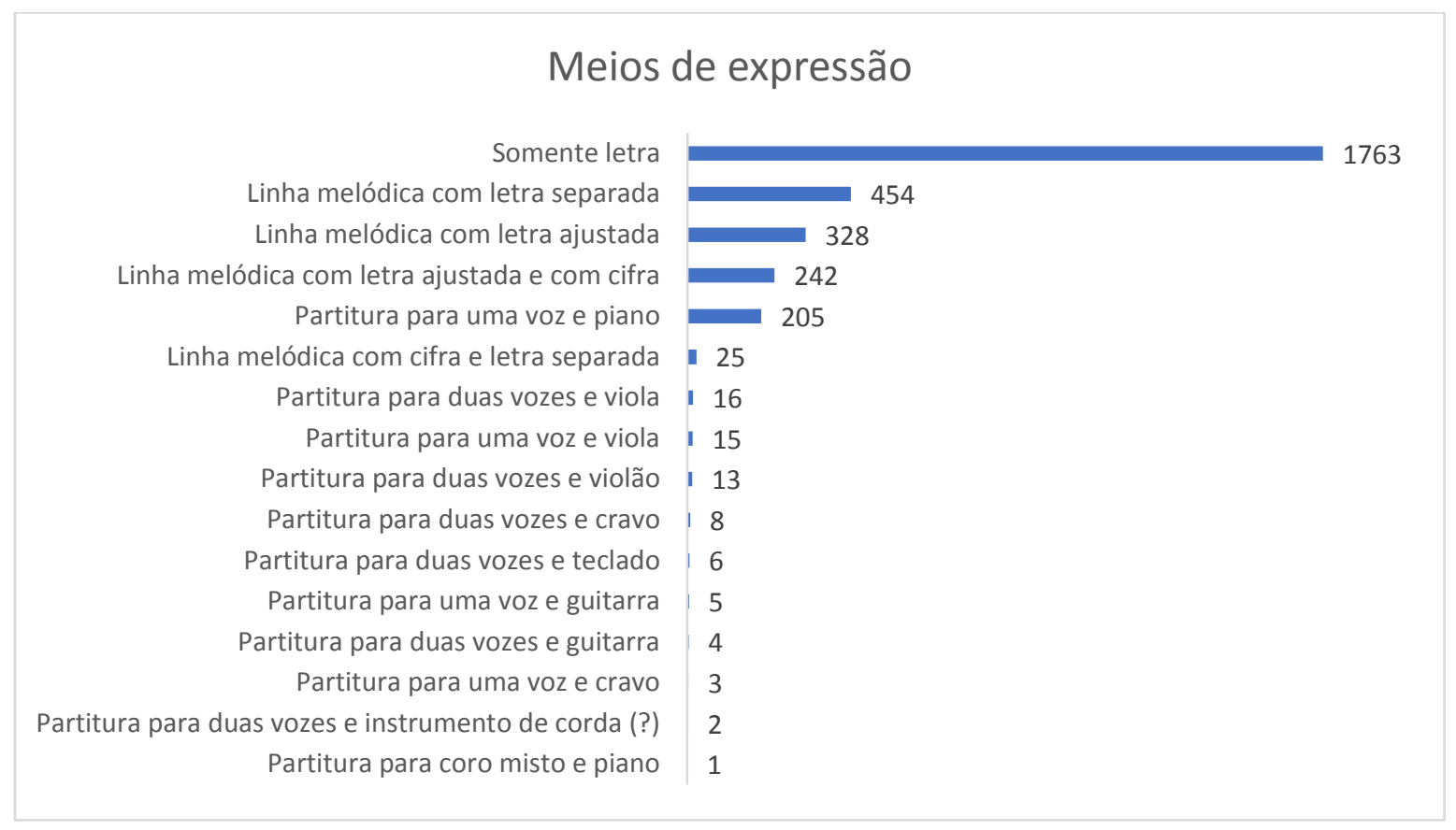

Fonte: Lista de modinhas

\subsection{Linha melódica}

Quando se tem acesso ao material musical escrito, uma partitura, é possível fazer uma análise minuciosa da linha melódica, sua extensão, seu contorno, se é ascendente ou descendente, se mantém o padrão rítmico, se possui ornamentos, se utiliza saltos ou grau conjunto, dentre outras características.

Sobre as modinhas impressas no Jornal de Modinhas, editado em Lisboa entre 1792 e 1796, Castagna observa que "estão presentes nas modinhas, como nas óperas daquele período, os duos em terças ou sextas paralelas, a ornamentação das linhas vocais e as melodias ricas em notas diminuídas ou passagens ágeis". As modinhas compostas no final do século XVIII e início do XIX têm como característica o canto a uma voz. Em alguns lugares ocorreu com participação coletiva alternando solista e coro, num estilo responsorial (CASTAGNA, 2003, p.2).

Não observamos a prática de terças e sextas paralelas nas modinhas de seresta presentes nas coletâneas que listamos no presente trabalho. No Brasil, o uso de terças ou sextas paralelas é amplamente utilizado na música caipira. Algumas modinhas tradicionais como Casinha Pequenina, Na casa branca da serra e Amo-te muito, foram gravadas por duplas como Cascatinha e Inhana e Pena Branca e Xavantinho integrando-se muito bem ao repertório caipira. Não adentraremos no repertório do que é considerado música caipira, 
porém levantamos a questão: não existe modinha nesse repertório? A partir do meio do século XVIII, o fato de ser cantado a duas vozes faz com que a música não possa ser considerada uma modinha?

Mário de Andrade atenta para o costume do canto solista no Brasil

No Brasil se canta bastante. Até posso falar que se canta por demais. Porém assuntando de mais perto a maneira de cantar do brasileiro, a gente põe logo reparo num caráter do nosso canto que se reforça um traço da psicologia nacional, vai, no entanto, diretamente de encontro à tentativa do professor Lozano e do nosso Orfeão. É que o canto brasileiro é essencialmente individualista. Há uma falta quase sistemática de canto socializado no Brasil. Até nossos Cantos-de-trabalho no geral são individuais. Pregões, por ex., a gente colhe milietas deles por aí tudo, mas se procura uma cantiga organizadora de trabalho coletivo, quase não acha.[...](ANDRADE, 2015, p.1).

As modinhas de salão presentes nas coletâneas listadas apresentam linhas melódicas solistas, exceto as modinhas do livro de Lima que possui exclusivamente modinhas para duas vozes. A coletânea elaborada por Morais possui modinhas solistas e para duas vozes. A colecção de modinhas brazileiras impressa por LaForge, as 20 modinhas reunidas e harmonizadas por Neukomm e a Coleção de modinhas de bom gosto de João Francisco Leal são escritas para voz solo. Essas obras têm na construção da linha melódica, a presença de ornamentos. É possível perceber também, a presença de ornamentos, embora com menor incidência, em algumas modinhas de compositores brasileiros dos séculos XX como Carlos Gomes e Heitor Villa-Lobos, presentes no repertório de canto.

Adriana Almeida, em trabalho de dissertação de mestrado na UNICAMP, buscou no bel canto e seu aculturamento no Brasil um recurso interpretativo na ornamentação e improvisação em modinhas luso-brasileiras.

Almeida explica que, “dependendo de período histórico, filiação estética, nacionalidade e até idiossincrasias, a ornamentação poderá estar incorporada à escrita sem distinção clara da linha estrutural, ser anotada com notas de tamanho menor ou símbolos”. A autora destaca que, no período que vai da chegada da família real, em 1808, até a abdicação de D.Pedro I, em 1831, chegaram ao Rio de Janeiro músicos treinados na estética e na técnica europeia; e essa movimentação causou impacto no cenário musical do Brasil, sobretudo nas questões vocais com a chegada dos castrati, cantores de ópera e professores de canto 
(ALMEIDA, 2014, p.21).

As reduções e as ornamentações provavelmente estiveram presentes em interpretações de acordo com a época, bem como as linhas de baixo ou esquemas harmônicos, mas infelizmente, por falta de registro, muitas se perderam. Pacheco observa que "[...] a maneira como era executada dependia do gosto e da formação musical de cada intérprete, quanto mais numa sociedade tão heterogênea como aquela do Rio joanino...” (PACHECO,2007, p.300).

Como não podia deixar de ser, a permanência da corte também afetou a linha vocal das modinhas. O estilo rossiniano que invadiu o teatro e a escola vocal dos cantores europeus foram influência considerável. A penetração do modelo europeu fica muito clara nas cadências vocais de algumas modinhas e na linha vocal bastante ornamentada e cheia de passagens de agilidade. Como exemplo disto, podemos citar a Coleção de modinhas de bom gosto composta por João Francisco Leal e publicada em 1830 (PACHECO, 2007, p..301).

Pacheco destaca em sua tese de doutorado Cantoria Joanina: a prática vocal carioca sob influência da corte de D. João VI, castrati e outros virtuoses a influência que os músicos estrangeiros exerceram no cenário musical do Rio de Janeiro com a vinda de intérpretes que primavam pelo virtuosismo vocal (PACHECO,2007).

Sobre as terminações, ou seja, finalizações de frases, Lima observa que, a maior parte das modinhas presentes no livro Modinhas do Brasil possui terminação feminina, ou seja, finaliza no tempo não acentuado do compasso. Observamos que a terminação feminina também foi utilizada por compositores de modinhas de salão para voz solista, bem como por compositores de modinhas de seresta (LIMA, 2001, p.21).

Em relação à extensão da linha melódica, Lima observa que, na coleção que analisou, as modinhas possuem extensões que variam de uma sexta $\left(6^{\mathrm{a}}\right)$ a uma décima terceira $\left(13^{\mathrm{a}}\right)$; porém, afirma que a maior parte possui extensão de nona $\left(9^{\mathrm{a}}\right)$ e décima primeira $\left(11^{\mathrm{a}}\right)(\mathrm{LIMA}$, 2001, p.20).

Mendes, na Contribuição para o estudo da modinha destaca que as modinhas analisadas possuem grande extensão e variam entre uma sétima diminuta $\left(7^{\mathrm{a}} \mathrm{dim}\right)$ até uma décima segunda $\left(12^{\mathrm{a}}\right)$. Mendes observou que a maior parte das modinhas possui extensão de nona e de décima primeira conforme descrição a seguir, a qual cita a extensão e o número de ocorrências na coletânea. 
Nona $\left(9^{\mathrm{a}}\right)-11$ modinhas

Décima primeira $\left(11^{\mathrm{a}}\right)-9$ modinhas

Décima $\left(10^{\mathrm{a}}\right)-4$ modinhas

Oitava $\left(8^{\mathrm{a}}\right)-4$ modinhas

Décima segunda $\left(12^{\mathrm{a}}\right)-3$ modinhas

Sétima $\left(7^{\mathrm{a}}\right)-1$ modinha

Galvão em A modinha Norte Rio-Grandense observa que as melodias são "curtas e não se observam saltos muito longos nos intervalos entra as notas, indicando a possibilidade de serem cantadas por qualquer pessoa sem nenhum conhecimento do canto erudito". O autor destaca a diferença na ausência de saltos na construção da linha melódica das modinhas locais, recurso usual nas modinhas imperiais (GALVÃO, 2000, p.44).

A análise da linha melódica nas modinhas de seresta requer uma comparação entre as diferentes versões colhidas e impressas em livros de coletânea. Como fazem parte do processo de transmissão oral e não foram registradas logo que foram compostas, sofreram alterações no processo de circulação, apresentando diferenças em cada lugar em que foram cantadas. Algumas alterações percebidas são mudanças de texto, diferenças na divisão do texto, diferenças na fórmula de compasso e diferenças na melodia.

Ulhôa em seu trabalho de análise sobre a transmissão oral/aural levanta a possibilidade de análise comparativa por meio da escuta. Ela utiliza o método adotado por James Cowdery que ao escutar um material sonoro a comparação deve ser feita com outro material sonoro. Entendemos que ao analisar as várias versões escritas de uma linha melódica de uma modinha de seresta é possível e desejável ao intérprete compará-las com as gravações e buscar a que mais lhe imprima significado, uma vez que nem mesmo as gravações garantem a legitimidade de uma obra cuja transmissão foi oral e que não se sabe ao certo a sua procedência primeira. $\mathrm{O}$ que se pode constatar é que naquele local era cantada daquela forma. Como já citado anteriormente, o objetivo não é atestar legitimidade ou qual versão é a mais correta, ou a mais próxima da verdade, uma vez que é impossível, mas entendemos que a consciência dessas variações é importante no processo de reflexão das práticas interpretativas.

Ulhôa destaca a importância da escuta no processo de apropriação do material. Embora saibamos que algumas modinhas não possuem gravação, buscamos o maior número de gravações do início do século XX, bem como gravações atuais. 
A escuta preliminar do repertório disponível de modinhas de tradição oral gravadas ainda não permite qualquer generalização. Algumas modinhas parecem ligadas a uma estrutura tradicional (canção com estrofes de quatro versos, melodia em seqüência, clímax e frase conclusiva, sendo que não sabemos ainda o significado da repetição freqüente do terceiro e quarto versos); outras divergem bastante deste modelo tradicional, sendo talvez adaptações de melodias de árias de ópera, zarzuelas ou operetas (ULHÔA, 2008,p.7).

Portanto, no caso das modinhas de seresta, é de suma importância comparar o material escrito com o material gravado.

Observando o gráfico abaixo podemos perceber que, nas coletâneas presentes nessa pesquisa, existe um número maior de obras cujas músicas estão registradas em partituras contendo apenas a linha melódica. As coletâneas com essas características foram construídas com base na coleta e no registro da memória de pessoas que conheciam as músicas. Esse movimento de registro começou com as canções folclóricas, os brinquedos, os cantos populares e passou também pelas modinhas no início do século XX.

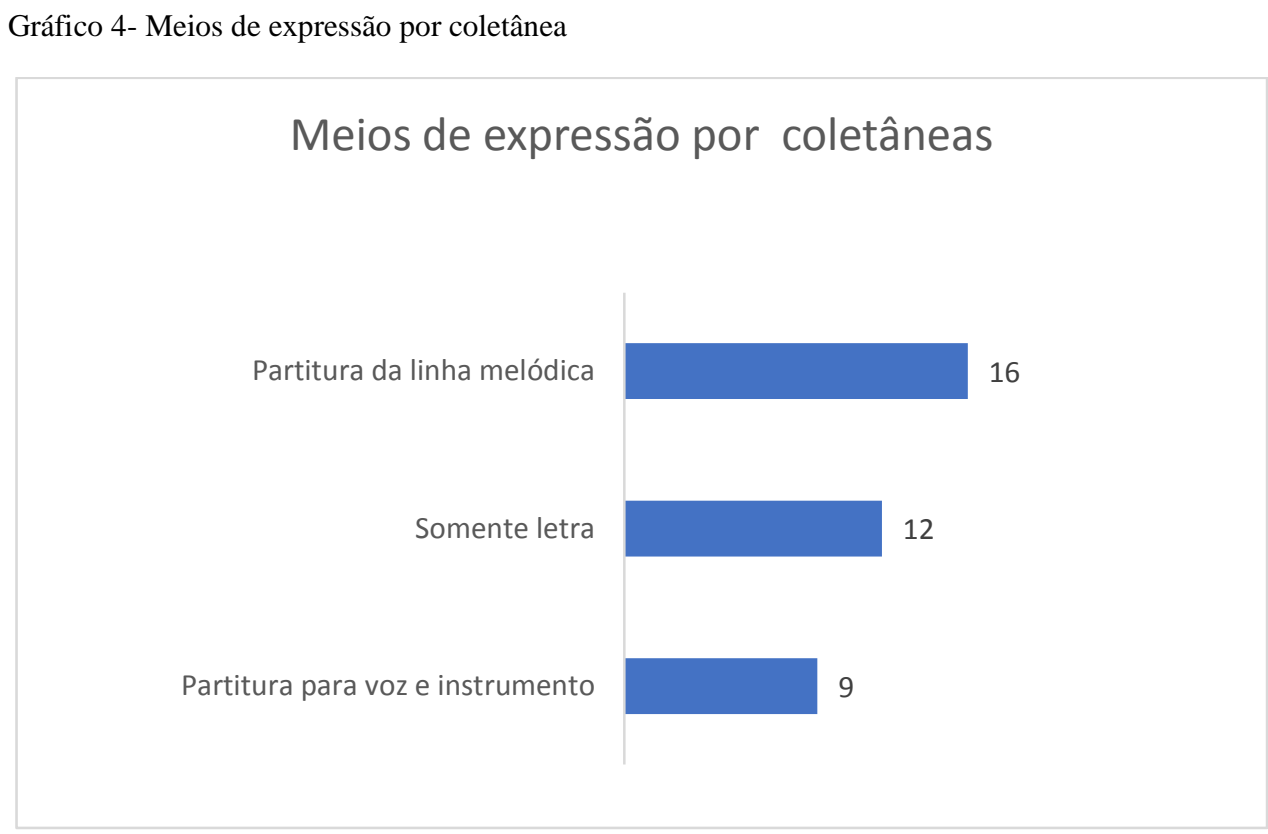

Fonte: Lista de coletâneas

Retomando as perguntas iniciais desse capítulo acreditamos que para identificar quais são as modinhas dentro de um repertório é preciso identificar o que é uma modinha? Para estudar as modinhas é necessário observar seus espaços geográficos, costumes, intérpretes, 
instrumentações, temas, estruturas poéticas, formas musicais e construção melódica. Desse conjunto de critérios, os temas, as estruturas poéticas e as formas musicais seriam importantes na indicação do que pode ser considerado modinha ou não, separando-a de outros gêneros. Mas como é possível identificar uma modinha de salão e uma modinha de seresta? De todos os critérios elencados, acreditamos que a observação da construção da linha melódica seria o critério principal para essa seleção.

No repertório de modinhas observamos que as melodias das modinhas de seresta possuem uma nota por sílaba como exemplificado na modinha Soluçando te digo um triste adeus (fig.12 )e as melodias das modinhas de salão utilizam ornamentações que fazem com que uma sílaba seja utilizada em várias notas, como grupetos, trinados e melismas, como é possível perceber na modinha Meu coração vivia izento (fig.13). Tanto as modinhas de seresta quanto as modinhas de salão utilizam apojaturas, retardos e antecipações (MENDES, 1959,p.129),(LAFORGE, s/d, s/n).

Figura 12- Trecho da modinha de seresta Soluçando te digo um triste adeus

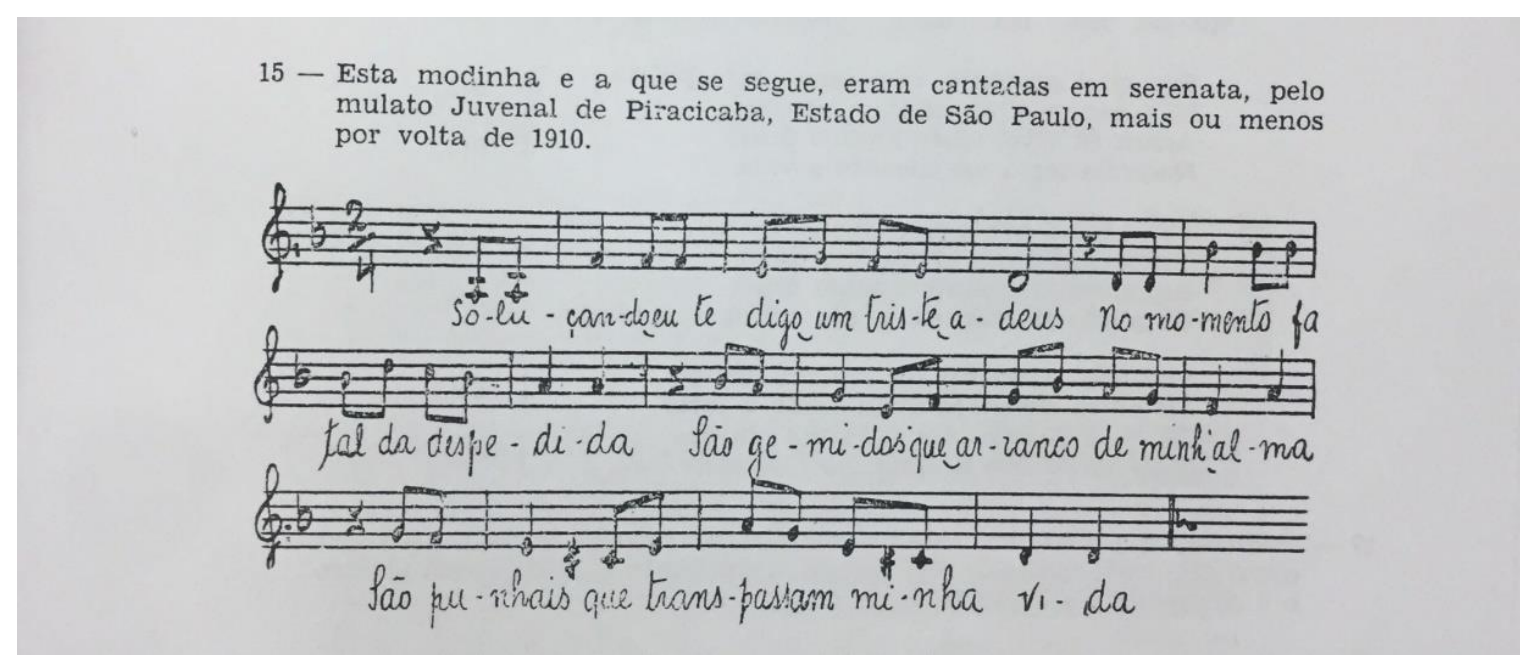

Fonte: Contribuição para o estudo da modinha 


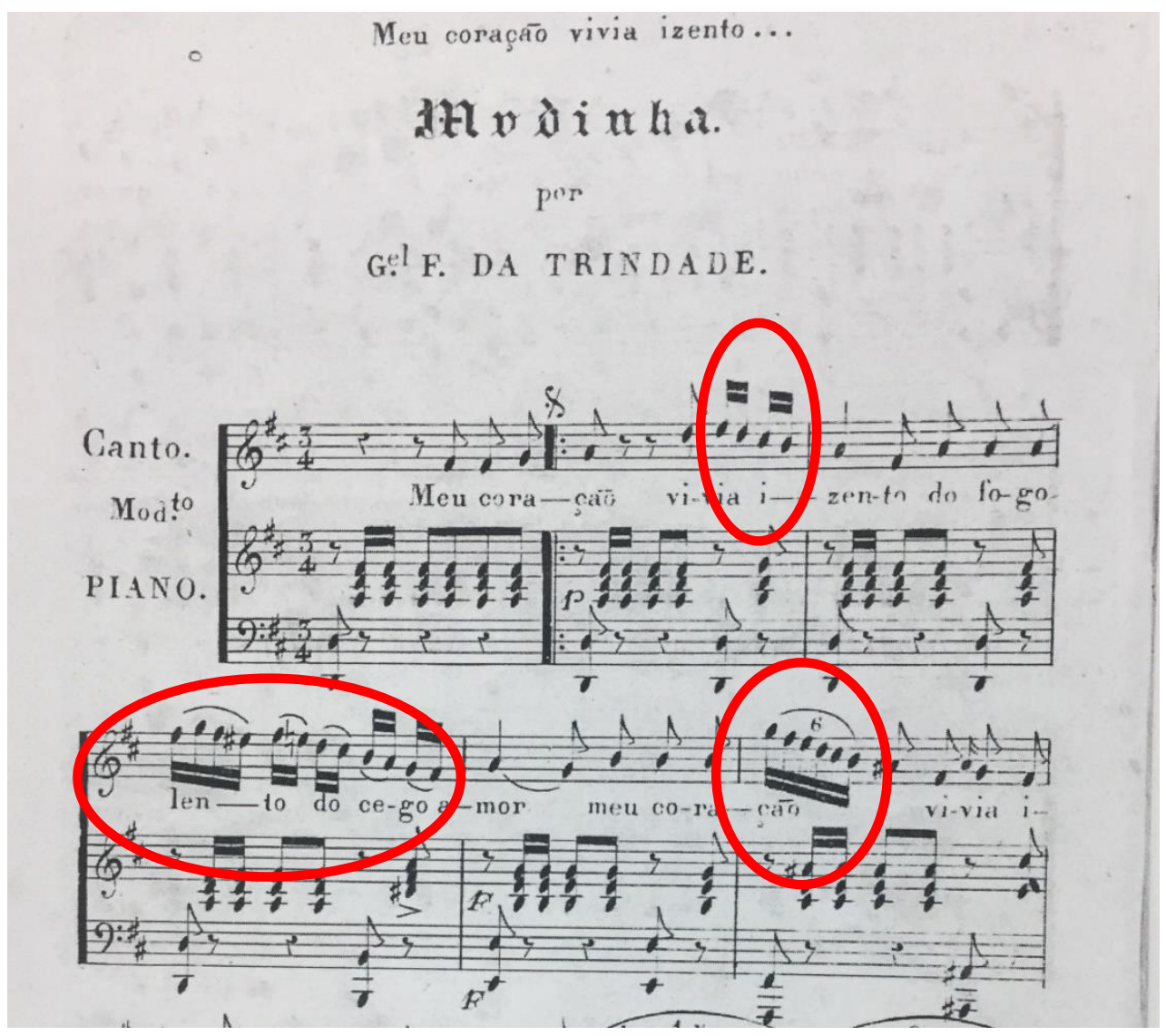

Fonte: Collecção de modinhas brazileiras

\section{3 - CIRCULAÇÃO}

O terceiro capítulo trata da análise das obras escolhidas que circularam por diferentes ambientes e tempos históricos. Adotamos a abordagem comparativa com o objetivo de apontar encontros e desencontros, ou seja, semelhanças e diferenças na circulação e nas práticas interpretativas e não de buscar legitimidade, identificação da versão verdadeira ou correção de possíveis erros de registro. Também incluiremos alguns registros sonoros nesse processo de comparação com o objetivo de refletir sobre as escolhas feitas pelo intérprete.

No nosso trabalho, não teremos um documento de referência, uma vez que o objetivo não é buscar a fonte mais fiel, ou mais verdadeira, mas sim observar os processos, identificar e refletir sobre os tipos de modinha na produção escrita literária e musical observando-se as três noções levantadas por Chartier: representação, prática e apropriação, levando-se em conta a circulação e as práticas interpretativas (CHARTIER, 2002).

Vilela ressalta que no Brasil, em determinado momento, a modinha de origem na 
corte, ou seja a modinha de salão, foi acompanhada por um instrumento popular: a viola. Já o lundu, de origem popular, foi executado ao piano.

Notamos aí um entrelaçamento de matrizes musicais revelando, primeiro, o constante trânsito de informações que fluía entre os estratos sociais; segundo, o que seria uma característica comum da música popular brasileira até a década de 1970: a deglutição seguida da digestão e posterior fusão de toda matéria musical que se aproximasse. A tradição modinheira se faz presente até hoje nos interiores do Brasil (VILELA, 2013, p. 41).

É possível perceber o entrelaçamento de matrizes musicais observando-se os processos de aproximação e fusão presentes na modinha, que se afiguram na temática, na instrumentação, na construção melódica e harmônica utilizadas nas obras que foram recolhidas em diversos pontos do Brasil e em diferentes tempos históricos.

Para Chartier, representação é o modo como em diferentes lugares e tempos a realidade social é construída e como esses padrões, códigos e sentidos são compartilhados, passando a ser praticados e, em seguida, gerando outras representações e práticas, numa corrente que constrói novas concepções culturais. Com base nessas relações, as pessoas se apropriam e criam novas concepções, provenientes de aceitação ou imposição (CHARTIER, 2002).

Acreditamos que esse processo foi vivenciado nas modinhas tanto do salão para seresta quanto da seresta para o salão. As duas principais linhas de estudo sobre a modinha corroboram para essa afirmação.

Para Tinhorão a modinha chegou a Portugal levando como principal elemento a originalidade. Porém, essa originalidade que foi descrita pelo escritor português Antônio Ribeiro dos Santos como "a tafularia do amor, a meiguice do Brazil, e em geral a moleza americana" foi alcançando a corte e recebeu influência da música que também chegava da Itália, o bel'canto (TINHORÃO, 1990).

Por outro lado, a influência musical no Brasil, não só de Portugal, mas da Europa, foi muito marcante. Martha Ulhôa observa, por exemplo, que, no Brasil do século XIX, principalmente no Rio de Janeiro, o cenário musical era mediado pela Europa. Nesse momento, existia consumo de música no salão, no teatro e nas salas de concerto. 
O filtro da música européia a vir para o Rio de Janeiro era Paris; tudo que a burguesia parisiense consumia ao longo do século XIX - ópera italiana, canto de salão, música sinfônica e de câmera alemã, música de dança espanhola "exótica" - repercutia nos salões, salas de concerto e teatros cariocas. Esse processo de transmissão era mediado por imigrantes portugueses, italianos, franceses e alemães que passaram a ocupar posições de liderança no teatro e no negócio da música em geral (provendo música para bailes e ocasiões sociais, além de ensinar privadamente e instituir casas de impressão musical) (ULHÔA, 2008,p.253).

Quando e onde é possível perceber a circulação de elementos ? Quais as mudanças? O que se repete? O que se transforma? Com base nessas perguntas, iniciamos a análise da tabela de modinhas por meio da criação de gráficos. Logo abaixo, listamos a movimentação percebida nas coletâneas cadastradas, especificando em quantas fontes cada obra aparece.

Tabela 5- Contagem de fontes por título

\begin{tabular}{|l|r|}
\hline Rótulos de Linha & Contagem de Fonte \\
\hline Ao luar & 11 \\
\hline Serenata & 9 \\
\hline O Poeta e a Fidalga & 8 \\
\hline Modinha & 7 \\
\hline A despedida & 7 \\
\hline Desalento & 7 \\
\hline Ave Maria & 6 \\
\hline Borboleta & 6 \\
\hline Partida & 5 \\
\hline O gondoleiro do amor & 5 \\
\hline Sempre te amando & 5 \\
\hline A mulata & 5 \\
\hline Barcarola & 5 \\
\hline Confissão e desengano & 5 \\
\hline Prazeres que eu não sonhava & 5 \\
\hline Recorda-te de mim & 5 \\
\hline O Bem-te-vi & 5 \\
\hline Morena & 5 \\
\hline Teu nome & 5 \\
\hline Eram dez horas & 5 \\
\hline Penso em ti & 4 \\
\hline Stella & 4 \\
\hline Adeus & 4 \\
\hline Amor perfeito & 4 \\
\hline A casinha Pequenina & 4 \\
\hline Inda sou teu & 4 \\
\hline Ciumes & 4 \\
\hline Zabumba & 4 \\
\hline Dá-me um beijo & 4 \\
\hline
\end{tabular}




\begin{tabular}{|l|r|} 
Meiga Virgem & 4 \\
\hline A gentil Carolina & 4 \\
\hline A côr morena & 4 \\
\hline Canção do Trovador & 4 \\
\hline Assim & 4 \\
\hline Perdão & 4 \\
\hline Mucama & 4 \\
\hline Queixas a amor & 4 \\
\hline Não Corras na Areia & 4 \\
\hline Se eu fora poeta & 4 \\
\hline Não és tu & 4 \\
\hline Dá-me um sorriso & 4 \\
\hline Não sei & 4 \\
\hline Amanhã & 4 \\
\hline A Casa Branca da Serra & 4 \\
\hline Um sonho & 4 \\
\hline Quero fugir-te & 3 \\
\hline Soluçando & 3 \\
\hline Saudades de Maura & 3 \\
\hline Foi cruel o meu destino & 3 \\
\hline A canção do africano & 3 \\
\hline A marrequinha & 3 \\
\hline A esperança & 3 \\
\hline Trovador & 3 \\
\hline Deixei Cabanas & 3 \\
\hline Laura & 3 \\
\hline Tristes saudades & 3 \\
\hline Luar do Sertão & 3 \\
\hline Quando Meu Peito & 3 \\
\hline Aonde está o meu bem? & 3 \\
\hline Quizera amar-te & 3 \\
\hline Apanhe para seu ensino & 3 \\
\hline Saudade & 3 \\
\hline Minha terra tem palmeiras & 3 \\
\hline De livre que sempre fui & 3 \\
\hline Aquelas cartas que te dei tremendo & 3 \\
\hline Sobre as ondas & 3 \\
\hline As bahianas & 3 \\
\hline Desejo & 3 \\
\hline As duas flores & 3 \\
\hline Como o orvalho da noite & 3 \\
\hline Mulatinha do caroço & 3 \\
\hline Quando as glorias que gosei & 3 \\
\hline A brisa corre de manso & 3 \\
\hline Ai de mim & 3 \\
\hline A primavera & 3 \\
\hline Quisera amar-te & 3 \\
\hline A rosa & 3 \\
\hline Noite cheia de estrelas & 3 \\
\hline Rosa & 3 \\
\hline & \\
\hline
\end{tabular}




\begin{tabular}{|l|r|}
\hline Saudades & 3 \\
\hline Beijo a mão que me condemna & 3 \\
\hline Se és anjo no gesto e belleza & 3 \\
\hline O canto do Cysne & 3 \\
\hline Se soubesses & 3 \\
\hline O fatal segredo & 3 \\
\hline Amor de mãi & 3 \\
\hline A rosa murcha & 3 \\
\hline Soldado de amor & 3 \\
\hline Canção & 3 \\
\hline Sonhei & 3 \\
\hline Olhos Azuis & 3 \\
\hline Dorme, dorme, ó morena & 3 \\
\hline A vida e a morte & 3 \\
\hline A concha e a virgem & 3 \\
\hline Acabou-se a minha crença & 3 \\
\hline Já passei dias felizes & 3 \\
\hline Maria & 3 \\
\hline As horas que passo & 2 \\
\hline Pallida Madona & 2 \\
\hline O canto da noiva & 2 \\
\hline A B C do Amor & 2 \\
\hline Ao som da Lyra a chorar & 2 \\
\hline Cada vez querer-te eu mais & 2 \\
\hline Bem como o orvalha da noite & 2 \\
\hline Camélia & 2 \\
\hline O poeta e a lira & 2 \\
\hline A estrella de minha vida & 2 \\
\hline Porque não me casei & 2 \\
\hline Canção do exílio (2) & 2 \\
\hline Remae, remae & 2 \\
\hline Canção do marinheiro & 2 \\
\hline Sobre o mar & 2 \\
\hline A saudade me flagella & 2 \\
\hline Ursulina & 2 \\
\hline Cantigas & 2 \\
\hline Amor generoso & 2 \\
\hline Caso de amor tão fingido & 2 \\
\hline Oh Sorte minha cruel & 2 \\
\hline Cearenses & 2 \\
\hline Perigo & 2 \\
\hline Céus, por piedade & 2 \\
\hline Quando no tumulo & 2 \\
\hline Chão de estrelas & 2 \\
\hline A casa mal assombrada & 2 \\
\hline Chiquinha & 2 \\
\hline Rosto d'anjo & 2 \\
\hline Semoro a minha desventura $-v i v a ~$ & 2 \\
\hline Chuá - Chuá & 2 \\
\hline Chuchar no dedo & 2 \\
\hline & 2 \\
\hline & 2 \\
\hline
\end{tabular}




\begin{tabular}{|l|r|} 
Tu & 2 \\
\hline Ciume, cruel ciume & 2 \\
\hline O beijo & 2 \\
\hline A ternura brazileira & 2 \\
\hline O cego & 2 \\
\hline Clamor de Lereno & 2 \\
\hline O Meirinho e a Pobre & 2 \\
\hline Com vida, embora com vida & 2 \\
\hline O seu moleque sou eu & 2 \\
\hline A tirqueia & 2 \\
\hline Os ciumes & 2 \\
\hline Como se ama a Deus no céo & 2 \\
\hline Amo-te muito & 2 \\
\hline A trança & 2 \\
\hline Ponto Final & 2 \\
\hline Crime gostoso & 2 \\
\hline Puros votos eu jurei & 2 \\
\hline Cruel saudade & 2 \\
\hline Que valem flores & 2 \\
\hline Cuidados tristes cuidados & 2 \\
\hline Queres que eu chore? & 2 \\
\hline Cumprimento do voto & 2 \\
\hline Recordação & 2 \\
\hline A vez primeira & 2 \\
\hline Rosa colhia sozinha & 2 \\
\hline A vida do frade & 2 \\
\hline As clarinhas e as moreninhas & 2 \\
\hline De huma simples amizade & 2 \\
\hline Se queres saber a causa & 2 \\
\hline A flor do maracujá & 2 \\
\hline Sertaneja & 2 \\
\hline De mim já se não lembra & 2 \\
\hline Sonhei comtigo donzella & 2 \\
\hline Declaração de Lereno & 2 \\
\hline Tecelona & 2 \\
\hline Deixa Dália, flor mimosa & 2 \\
\hline Bem fica & 2 \\
\hline A voz do violão & 2 \\
\hline Última estrofe & 2 \\
\hline A flor que tu me deste & 2 \\
\hline Boa-noite, Maria... & 2 \\
\hline Desde o dia em que te vi & 2 \\
\hline O bicho mulher & 2 \\
\hline Acorda & 2 \\
\hline Amor e medo & 2 \\
\hline Despedida & 2 \\
\hline O desejo & 2 \\
\hline Despeito & 2 \\
\hline Á lua & 2 \\
\hline Desperta nome do teu pastor & 2 \\
\hline Dileta & 2 \\
\hline & 2 \\
\hline
\end{tabular}




\begin{tabular}{|l|r|} 
O que é amor? & 2 \\
\hline Do Brazil a mulatinha & 2 \\
\hline O vagabundo & 2 \\
\hline Acorda, Adalgisa & 2 \\
\hline Ontem, ao luar & 2 \\
\hline E então & 2 \\
\hline Os olhos de Marilia & 2 \\
\hline E então? & 2 \\
\hline Partir levando a lembrança & 2 \\
\hline E foi-se & 2 \\
\hline Perdão Emilia & 2 \\
\hline É só por ti & 2 \\
\hline Pezares & 2 \\
\hline Elisa & 2 \\
\hline Por te amar sem esperança & 2 \\
\hline Elvira & 2 \\
\hline Primavera & 2 \\
\hline Elvira Escuta & 2 \\
\hline A crioula & 2 \\
\hline Elvira, escuta & 2 \\
\hline Que horas tristonhas & 2 \\
\hline Em horas mortas & 2 \\
\hline Queixa & 2 \\
\hline Em má hora & 2 \\
\hline Quem dá o que tem & 2 \\
\hline Era um anjo & 2 \\
\hline Quis debalde & 2 \\
\hline Acorda, desperta & 2 \\
\hline A mulher & 2 \\
\hline És Marilia & 2 \\
\hline Recordando & 2 \\
\hline Escuta & 2 \\
\hline Riso e morte & 2 \\
\hline Esperança & 2 \\
\hline Róseas flores d'alvorada & 2 \\
\hline Estas lágrimas sentidas & 2 \\
\hline Salve & 2 \\
\hline Estes mocinhos d'agora & 2 \\
\hline As flores d'alma & 2 \\
\hline Eu amo a brisa & 2 \\
\hline Se o pranto apreciares & 2 \\
\hline Eu amo as flores & 2 \\
\hline Segredo & 2 \\
\hline Eu já tive uma menina & 2 \\
\hline A preta mina & 2 \\
\hline Eu nasci sem coração & 2 \\
\hline Sim & 2 \\
\hline Eu sinto angustias & 2 \\
\hline Beijo a mão que me condena & 2 \\
\hline Eu sonhei que tu estavas tão linda & 2 \\
\hline Sonhei que mil flores & 2 \\
\hline Eu te adoro & 2 \\
\hline & 2 \\
\hline
\end{tabular}




\begin{tabular}{|l|r|}
\hline Talento e formosura & 2 \\
\hline Eu vi os olhos divinos & 2 \\
\hline Tenho medo do papao! & 2 \\
\hline Eu vivo triste & 2 \\
\hline Teus cabelos & 2 \\
\hline Faz hoje um ano & 2 \\
\hline Bemfica & 2 \\
\hline Feitiços da mulata & 2 \\
\hline Tudo no mundo é passageiro & 2 \\
\hline Flor gentil & 2 \\
\hline Um mysterio & 2 \\
\hline Foi assim o seu amor & 2 \\
\hline Varrer-te da memória & 2 \\
\hline Acorda, escuta, escuta & 2 \\
\hline O beija-flor & 2 \\
\hline Foi numa noite calmosa & 2 \\
\hline Amor do Brazil & 2 \\
\hline Foi por mim, foi pela sorte & 2 \\
\hline O botão de rosa & 2 \\
\hline Ganinha minha ganinha & 2 \\
\hline O canto da Virgem & 2 \\
\hline Gemo na dura prisão & 2 \\
\hline O caranguejo & 2 \\
\hline Gosto de ti & 2 \\
\hline O coração & 2 \\
\hline Gosto de Ti porque gosto & 2 \\
\hline O doce instante & 2 \\
\hline Grandezas da terra & 2 \\
\hline O gigante de pedra & 2 \\
\hline Guerra de amor & 2 \\
\hline O guarany & 2 \\
\hline Hei de amar-te até morrer & 2 \\
\hline O meu livre coração & 2 \\
\hline Impossível & 2 \\
\hline Amor que pode, me quis valer & 2 \\
\hline Acorda, minha querida & 2 \\
\hline O prazer que sinto n'alma & 2 \\
\hline Já mal posso respirar & 2 \\
\hline O sapo na lagoa & 2 \\
\hline Já Não me queres bem & 2 \\
\hline O Sonho & 2 \\
\hline A flor saudade & 2 \\
\hline Obrigar a que nos amem & 2 \\
\hline Já se quebrarão os laços & 2 \\
\hline Amor sabido vai gualdido & 2 \\
\hline Já tens um novo amor! & 2 \\
\hline Ora a Deos senhora Ulina & 2 \\
\hline Jacy olhos azues & 2 \\
\hline Lá para as bandas do Norte & 2 \\
\hline Lutras a mesma solfa & 2 \\
\hline & 2 \\
\hline
\end{tabular}




\begin{tabular}{|l|r|} 
Amo-te com amor mais santo & 2 \\
\hline Adormecida & 2 \\
\hline Pensando na partida & 2 \\
\hline Lembranças do nosso amor & 2 \\
\hline Anjo do céo, tu me matas & 2 \\
\hline Longe, bem longe & 2 \\
\hline Perdi a alegria & 2 \\
\hline Lua branca & 2 \\
\hline Pescador da barca bella & 2 \\
\hline Lua da estiva noite & 2 \\
\hline Poesia e amor & 2 \\
\hline Agonia & 2 \\
\hline Por entre as Trevas da noite & 2 \\
\hline Malandrinha & 2 \\
\hline Por ti & 2 \\
\hline Mar que outr'ora & 2 \\
\hline Antes, durante e depois & 2 \\
\hline Vem cá, minha companheira & 2 \\
\hline Primeiro amor & 2 \\
\hline Vem ver a lua & 2 \\
\hline Qualquer mulher qu'encontrares, & 2 \\
\hline Vingança & 2 \\
\hline Ao meu pensamento & 2 \\
\hline Volta & 2 \\
\hline Quando vejo o lindo rosto & 2 \\
\hline A corda sensível & 2 \\
\hline Que sorte, que sina & 2 \\
\hline Mater Dolorosa & 2 \\
\hline Quebrei a Jura & 2 \\
\hline Maura & 2 \\
\hline Queixas & 2 \\
\hline Meia - Noite & 2 \\
\hline Queixumes & 2 \\
\hline Ai segredo! & 2 \\
\hline Querem ver esta menina & 2 \\
\hline Menina dos olhos negros & 2 \\
\hline Ao ver-te & 2 \\
\hline Menina você que tem & 2 \\
\hline Ao violão & 2 \\
\hline Menina, porque razão & 2 \\
\hline Raivas de gosto & 2 \\
\hline Meu bem está mal com eu & 2 \\
\hline Recado & 2 \\
\hline Meu cafuné & 2 \\
\hline Recordações & 2 \\
\hline Meu coração vivia izento & 2 \\
\hline A noite & 2 \\
\hline Meu destino é immutável & 2 \\
\hline Retrato da minha linda Pastora & 2 \\
\hline Minha esperança & 2 \\
\hline A noite & 2 \\
\hline Minha Marilia não vive Sua existência findou & 2 \\
\hline & 2 \\
\hline
\end{tabular}




\begin{tabular}{|l|r|} 
Rosa do sertão & 2 \\
\hline Ais & 2 \\
\hline Roseas flores d'alvorada & 2 \\
\hline Minuete & 2 \\
\hline Roxa saudade & 2 \\
\hline Moda das caldas & 2 \\
\hline São ciumes de uma ingrata & 2 \\
\hline Moda de Tirce & 2 \\
\hline A pequenina cruz do teu rosário & 2 \\
\hline Modernismo & 2 \\
\hline Se a chama activa & 2 \\
\hline Ais de amor & 2 \\
\hline A portugueza abrazileirada & 2 \\
\hline Alerta que amor faz guerra & 2 \\
\hline Se os meus suspiros podessem & 2 \\
\hline Morena, teus olhos & 2 \\
\hline Assim como fai fai & 2 \\
\hline Alta noite & 2 \\
\hline Astuciosos os homens são & 2 \\
\hline Mulata cearense & 2 \\
\hline Serei triste até morrer & 2 \\
\hline A hora que te não vejo & 2 \\
\hline Serenata do Adeus & 2 \\
\hline Nada de saudades & 2 \\
\hline Si te adoro & 2 \\
\hline Amar sem interesse & 2 \\
\hline A dôr do meu coração & 2 \\
\hline Amei-te Elvira & 2 \\
\hline A Romã & 2 \\
\hline Não faz mal & 2 \\
\hline Bela virgem & 2 \\
\hline Não posso com mais ninguem & 2 \\
\hline Sonhei que dormias & 2 \\
\hline Não se morre de saudade & 2 \\
\hline Bella Nympha de minh'alma & 2 \\
\hline Não se resiste, não & 2 \\
\hline Suspiros do coração & 2 \\
\hline Amor brazileiro & 2 \\
\hline Tão longe & 2 \\
\hline Não tem mais que perguntar & 2 \\
\hline Tenho ciumes & 2 \\
\hline Nas horas negras da noite & 2 \\
\hline Teu juramento & 2 \\
\hline Nasci para te amar & 2 \\
\hline Teu sorriso & 2 \\
\hline Ninguem & 2 \\
\hline Triste lereno & 2 \\
\hline Ninguem tenha dó de mim & 2 \\
\hline Nropa de amor & 2 \\
\hline Trovas rosto ninguém vê & 2 \\
\hline No regaço da ventura & 2 \\
\hline & 2 \\
\hline
\end{tabular}




\begin{tabular}{|l|r|} 
Tu és o sol & 2 \\
\hline Amor concedeu-m' um premio & 2 \\
\hline Ultima esperança & 2 \\
\hline Noite tristonha & 2 \\
\hline Um ai gerado pela paixão & 2 \\
\hline Noivos & 2 \\
\hline Bem-te-vi & 2 \\
\hline Nubente & 2 \\
\hline Vamos, Eugênia & 2 \\
\hline A lavadeira & 2 \\
\hline Velho Realejo & 2 \\
\hline O barqueiro & 2 \\
\hline O beber & 2 \\
\hline Vendedora de amores & 2 \\
\hline Marília tu não conheces & 2 \\
\hline Você trata amor em brinco & 2 \\
\hline Marilia, escuta & 2 \\
\hline Vou partir & 2 \\
\hline Maringá & 2 \\
\hline A Amante do poeta & 2 \\
\hline Marinheiro & 2 \\
\hline Total Geral & 1013 \\
\hline
\end{tabular}

Fonte: Lista de modinhas

Encontramos 1013 obras envolvidas no levantamento de fontes impressas que dão mostras do processo de circulação das obras. As repetições aparecem em 2,3,4,5,6,7,8,9 e 11 fontes. Para análise da circulação das modinhas, observamos que algumas obras estão registradas em mais de uma coletânea. Para que se tenha uma visão de conjunto, formulamos a seguinte tabela que aponta o número de obras com mais de uma fonte, observando que há um caso de uma obra presente em 11 fontes diferentes e 315 obras presentes em duas fontes diferentes. 
Tabela 6- Processos de circulação

\begin{tabular}{|c|c|c|}
\hline $\begin{array}{c}\text { QUANTIDADE DE } \\
\text { OCORRÊNCIAS } \\
\text { (obras com mais de uma } \\
\text { fonte) }\end{array}$ & $\begin{array}{c}\text { QUANTIDADE DE } \\
\text { FONTES POR OBRA }\end{array}$ & $\begin{array}{c}\text { TOTAL DE OBRAS } \\
\text { LOCALIZADAS }\end{array}$ \\
\hline 1 & 11 & 11 \\
\hline 1 & 9 & 9 \\
\hline 1 & 8 & 8 \\
\hline 3 & 7 & 21 \\
\hline 2 & 6 & 12 \\
\hline 12 & 5 & 60 \\
\hline 25 & 4 & 100 \\
\hline 54 & 3 & 162 \\
\hline 315 & 2 & 630 \\
\hline TOTAL - 414 & & TOTAL - 1013 \\
\hline
\end{tabular}

Fonte: Lista de modinhas

Das 1013 obras listadas, 315 aparecem com o mesmo título em 2 fontes, 54 aparecem em 3 fontes, 25 em 4 fontes, 12 em 5 fontes, 2 em 6 fontes, 3 em 7 fontes, 1 em 8 fontes. 1 em 9 fontes e 1 em 11 fontes.

Observando as fontes, percebemos diferença nas características das publicações. Listamos 7 tipos de impressão conforme a descrição abaixo.

- Impressão de texto ou partitura sem fazer referência à outra fonte. A impressão de texto ou partitura sem fazer referência à outra fonte abre algumas possibilidades: pode ser a primeira impressão da obra ou o autor desconhece outra fonte em que ela foi registrada; ou ainda, o organizador não teve a preocupação de indicar a fonte.

- Reimpressão com repetição idêntica da obra (texto ou partitura) citando a fonte de onde foi retirada; 
- Reimpressão com repetição idêntica da obra (texto ou partitura) sem citar a fonte de onde foi retirada;

- Reimpressão com alterações (texto ou partitura), fazendo adequação da língua e/ou da notação musical, citando a fonte de onde foi retirada;

-Reimpressão com alterações (texto ou partitura), fazendo adequações da língua e/ou da notação musical, sem citar a fonte de onde foi retirada;

- Impressão ou reimpressão de registro de obra recolhida da tradição oral citando referência de outras fontes;

- Impressão ou reimpressão de registro de obra recolhida da tradição oral sem citar referências de outras fontes.

\subsection{Tipos de circulação}

Reimpressão com repetição idêntica da obra citando a fonte, em geral, é inserida como forma de circular o material. Araújo explica que reúne e insere em seu livro "[...]a coleção dessas árias, hoje quase inacessíveis pela raridade da obra em que foram publicadas[...]”. Era comum que o autor que detivesse uma obra original, rara e de difícil de acesso, utilizasse esse material em sua publicação (ARAUJO, 1959, p.139).

Araújo inseriu não só a partitura, mas também teve a preocupação de citar a fonte e inclusive inseriu a capa do cancioneiro de onde retirou, porém não fez uma reedição. Publicações com essa característica são mais voltadas para a exposição do acervo com menor preocupação com o uso do material pelo intérprete, uma vez que para fazê-lo será necessário buscar a fonte primária e reeditá-la por apresentar dificuldade de leitura decorrente da reimpressão. 


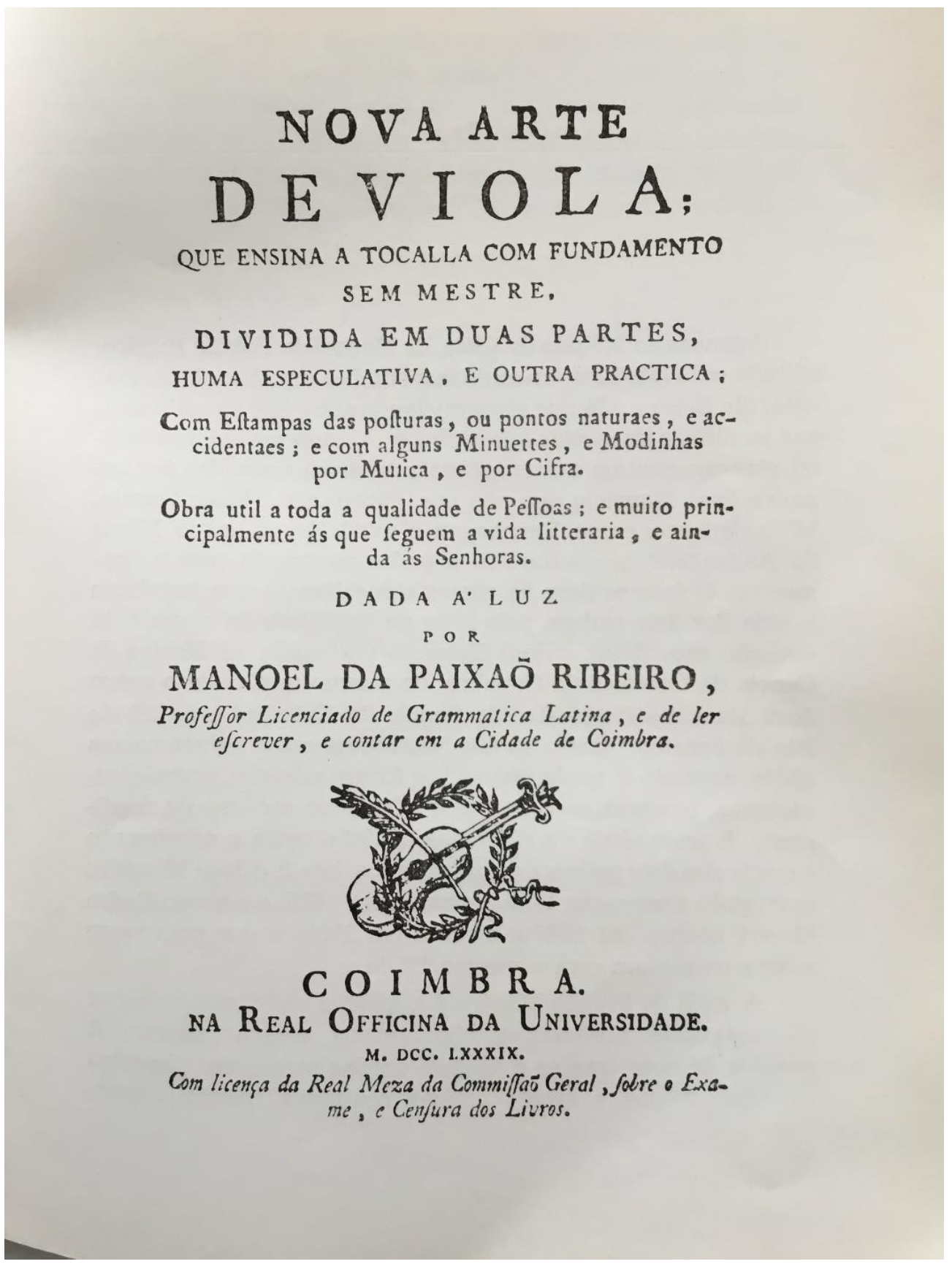

Fonte : A Modinha e o Lundu no século XVIII 
Figura 14- Partitura da modinha Marilia Bella

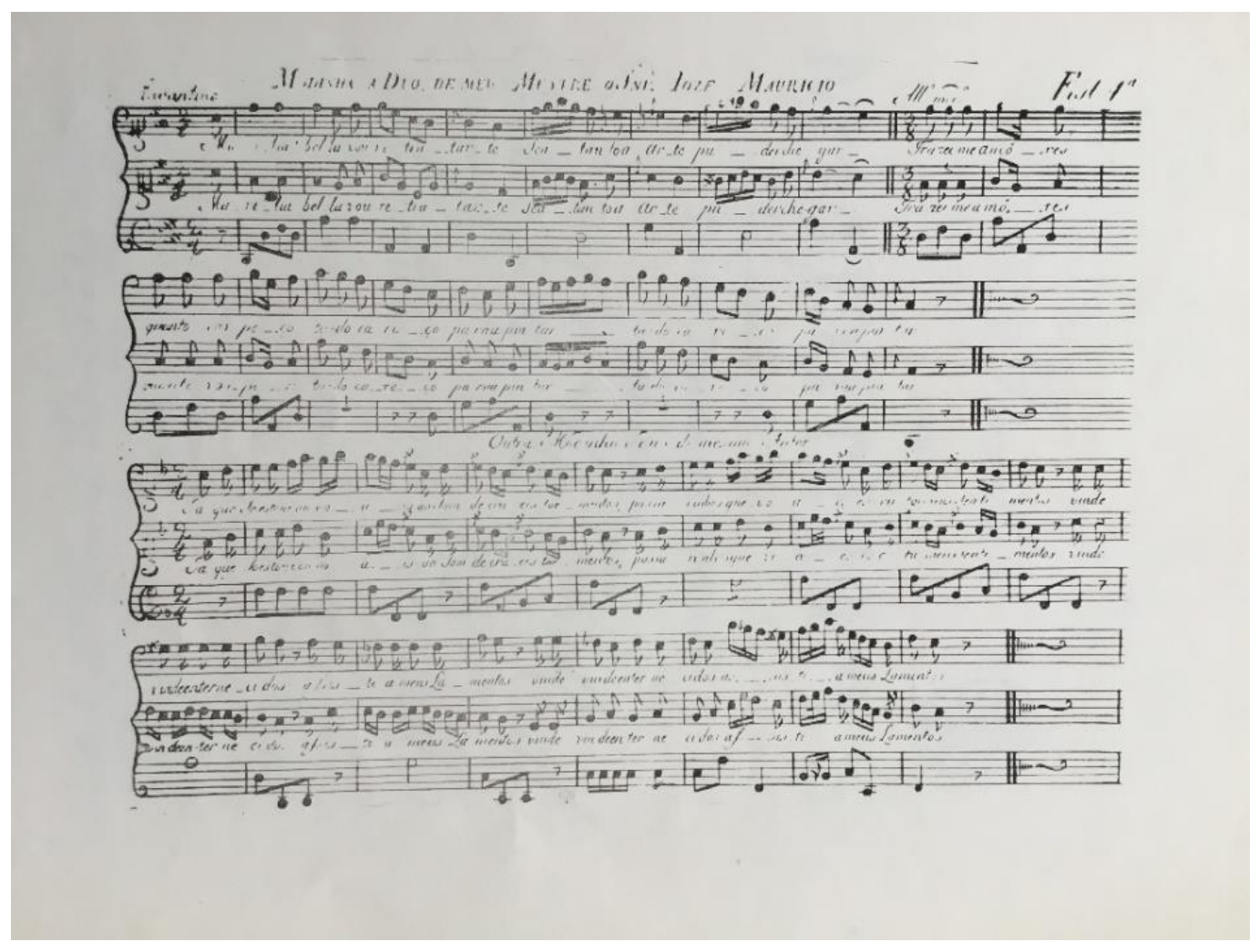

Fonte : A Modinha e o Lundu no século XVIII

- Reimpressão com alterações (texto ou partitura), fazendo adequação da língua e/ou da notação musical citando a fonte de onde foi retirada;

Normalmente ocorre em coletâneas mais atuais, em geral, ligadas a trabalhos acadêmicos de musicologia e/ou questões interpretativas. 


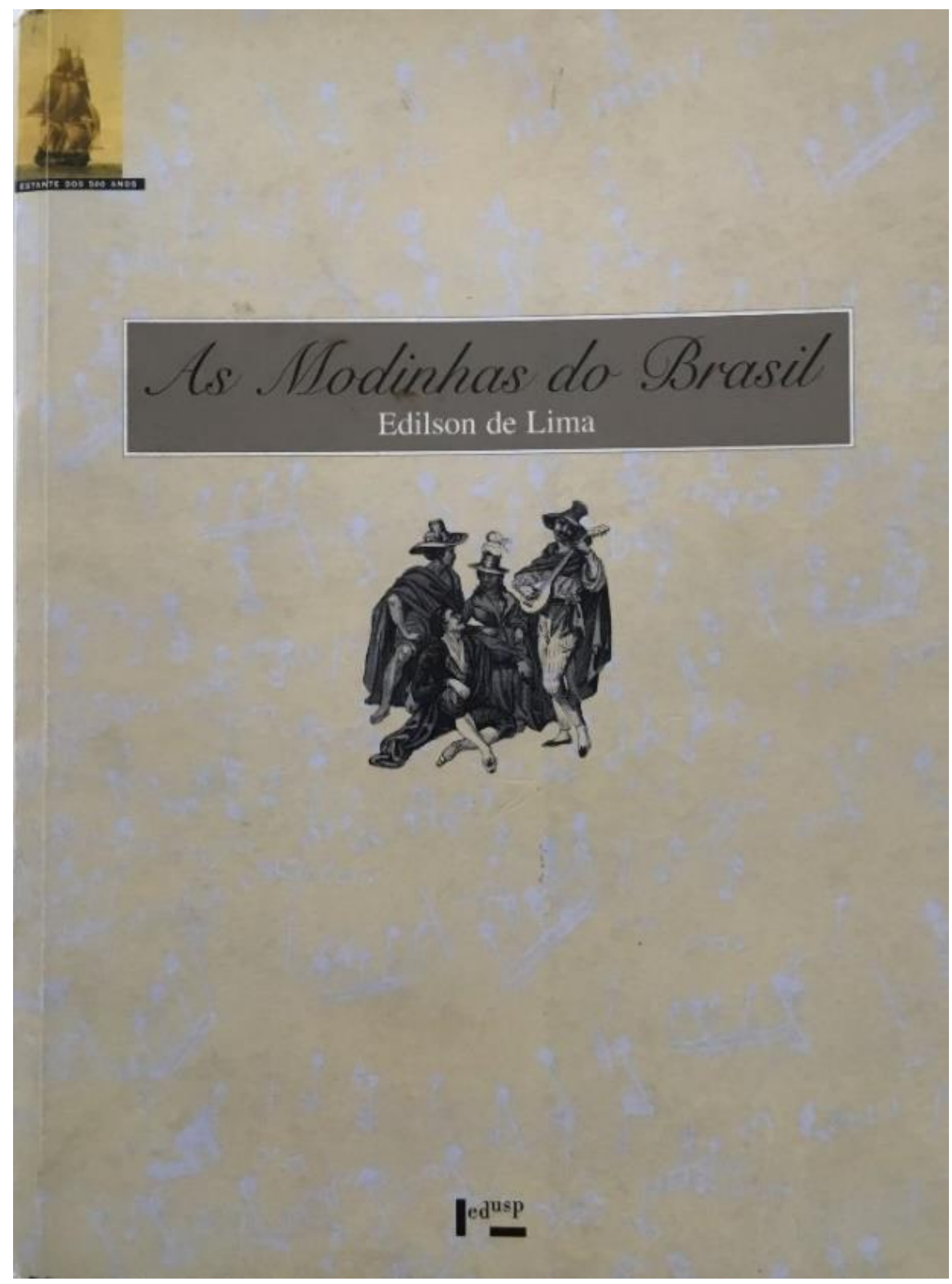

Fonte : As modinhas do Brasil

-Reimpressão com alterações (texto ou partitura), fazendo adequações da língua e/ou da notação musical sem citar a fonte de onde foi retirada;

- Impressão ou reimpressão de registro de obra recolhida da tradição oral citando referência de outras fontes; 
Ilustração 5- Capa do livro Modinhas Antigas

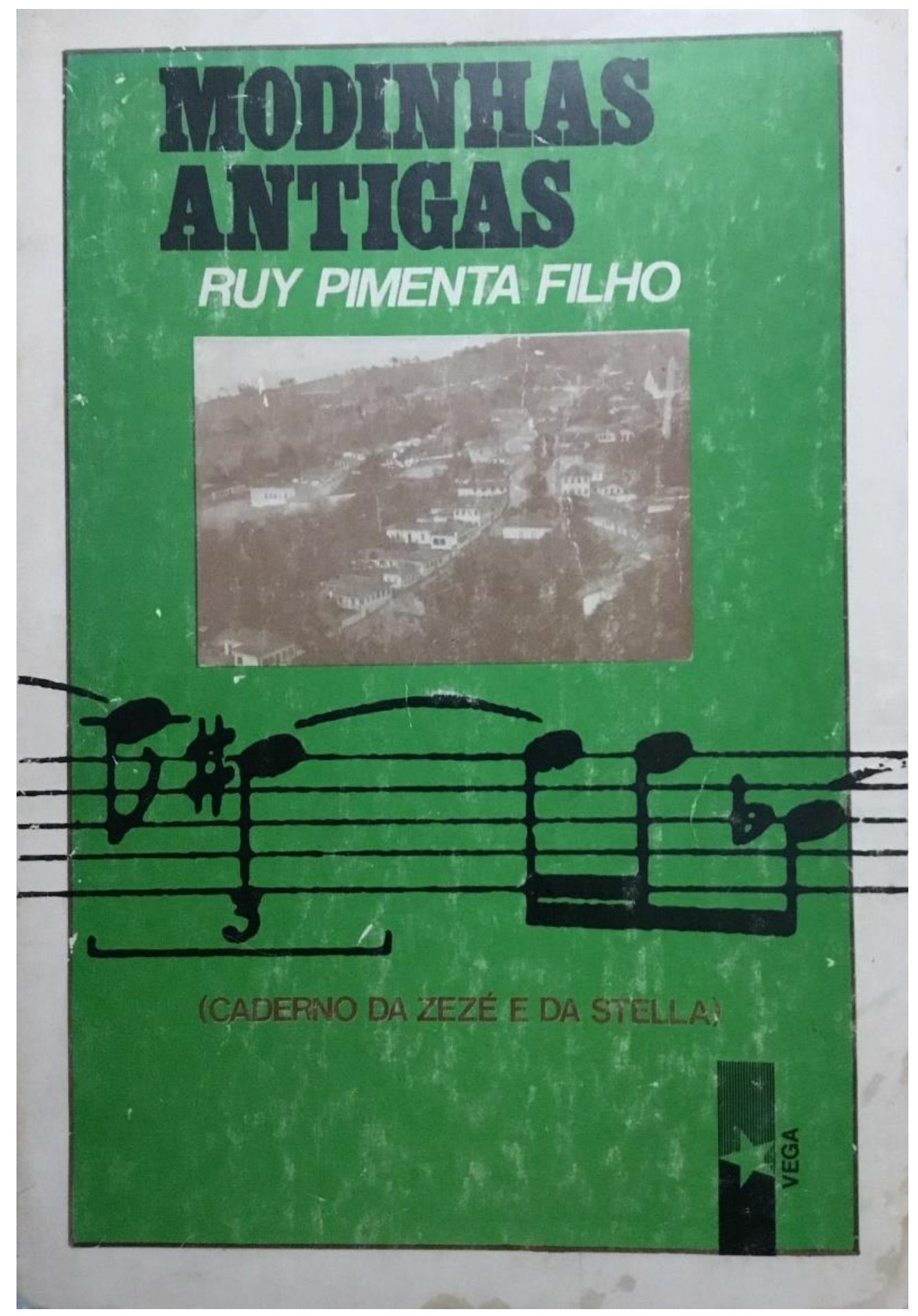

Fonte: Modinhas Antigas 
Figura 15- Trecho da letra da música Ao Luar

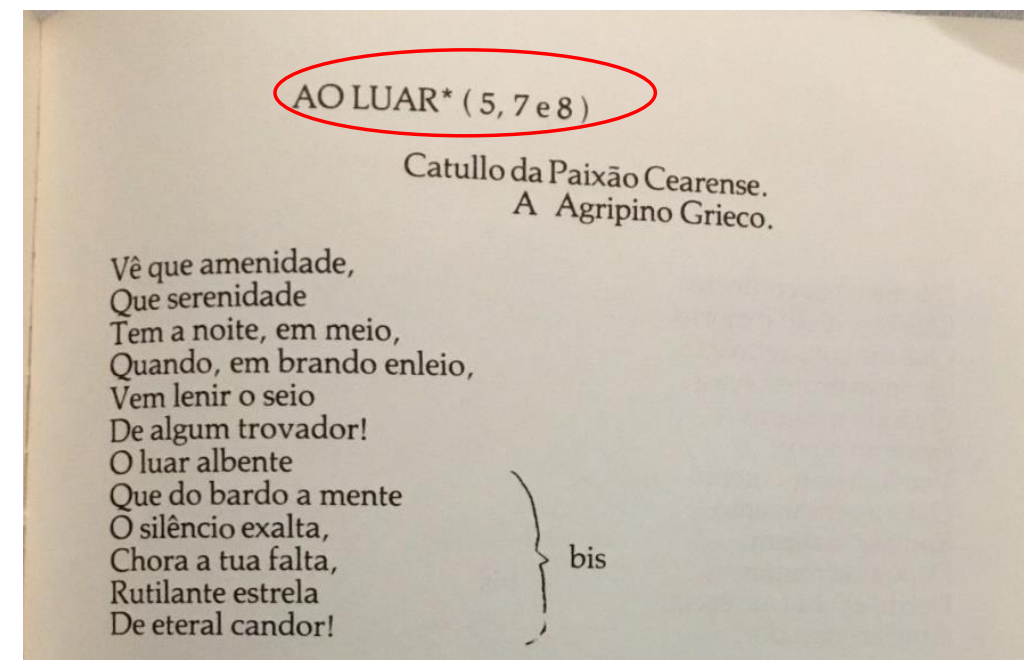

Fonte: Modinhas Antigas

Figura 16- Primeira página da bibliografia do livro Modinhas Antigas

\section{BIBLIOGRAFIA}

01 - ALVARENGA, Oneyda. Melodias Registradas por meios mecânicos. São Paulo, Prefeitura do Município.

Departamento Cultural, 1946.

02 - ANDRADE, Mário de. Modinhas Imperiais. São Paulo, Livraria Martins Ed., 1964.

03 - _ Ensaio sobrea Música Brasileira. São Paulo, Livraria Martins Ed., em convênio com Instituto Nac. do Livro/ MEC, 1972.

04 - ABREU, Casimiro Marques de. Poesias Completas. Rio de Janeiro, Edições de Ouro n. 83, 1965.

05. BRITOMENDES, J. Canções Populares do Brasil. Rio de

Janeiro, Editor J. Ribeiro Santos, 1911.

06 - CASTRO ALVES, Antônio de. Poesias Completas. São Paulo, Companhia Editora Nacional, 1959. 07 - CEARENSE, Catulo da Paixão. Modinhas. São Paulo,
Fermata, 1972.

08 - COUTINHO MAURÍCIO, Milene Antonieta. As Mais Belas Modinhas, Montes Claros, Espaço 2.

Gráfica \& Editora, 1976.

09 - FRANCCA JÚNIOR, Joaquim José Rio de Janeiro, Livraria Cruz Coutinho Hora de Cinismo.

10 -_. Defeito de Família. Rio Coutinho, 1870. Americàna, 1871.

Fonte: Modinhas Antigas 
-Impressão ou reimpressão de registro de obra recolhida da tradição oral sem citar referências de outras fontes.

-Reimpressão com repetição idêntica sem citar a fonte. O livro As mais belas modinhas possui trechos de obras retiradas do livro de Mozart de Araújo, porém não cita a fonte no corpo do texto, negando ao intérprete uma maior fundamentação, embora o objetivo tenha sido, como sempre, democratizar uma obra rara, esgotada e de difícil acesso. O livro consta na bibliografia.

$\mathrm{Na}$ nossa pesquisa, surgiram questões relativas à autoria, como no caso de $A s$ Bahianas, que aparece com três informações, uma em cada fonte: na mais antiga o compositor é desconhecido; na segunda fonte, o compositor é J.de S. Aragão e na terceira, os compositores de texto e música são Tito Livio e J.de S.Aragão.

Tabela 7- Informações da música As bahianas

\begin{tabular}{|l|l|l|l|l|}
\hline Título & Primeira frase $\sim$ Compositor & Poeta & $\nabla$ Fonte \\
\hline As bahianas & São astros luzentes Tito Livio - José de S. Aragão & $\begin{array}{l}\text { Tito Livio - José de S. As mais belas } \\
\text { modinhas Vol. II }\end{array}$ \\
\hline As bahianas & São astros luzentos José de S. Aragão & Tito Livio & $\begin{array}{l}\text { Canções } \\
\text { populares do } \\
\text { Brazil }\end{array}$ \\
\hline As bahianas & & São astros luzentes Desconhecido & Tito Livio & Serenatas e \\
\hline
\end{tabular}

Fonte: Lista de modinhas

Tabela 8- Ordem cronológica das fontes da música As bahianas

\begin{tabular}{|l|l|}
\hline FONTE & ANO DA PRIMEIRA PUBLICAÇÃO \\
\hline Serenatas e Saráus III & 1902 \\
\hline Canções Populares do Brasil & 1911 \\
\hline As mais belas modinhas & 1976 \\
\hline
\end{tabular}

Fonte: Lista de coletâneas

Abordamos anteriormente que o fato de os músicos não serem tão valorizados quanto os poetas, poderia, talvez, explicar uma parte das obras anônimas e das melodias perdidas. 
Porém, essa justificativa se aproxima mais das composições que não tiveram registro em partitura, ou seja, composições cujas melodias foram recolhidas anos depois da cultura oral. E as partituras anônimas? Por que as partituras eram impressas sem a autoria? Espasiani acredita que, a autoria dessas modinhas, que foram impressas como anônimas seja de músicos amadores. Os amadores, de estrato social elevado seriam, provavelmente, alunos dos músicos profissionais. Numa época em que o fazer amador era prestigiado e o profissional era desprezado, o anonimato era uma preservação. Afinal compor seria uma atividade complexa, própria dos profissionais. "Esse anonimato constitui-se, portanto, num discurso, já que é pela ausência da manifestação da autoria - voluntária e socialmente motivada pelo sentido de discriminação social - que o autor se identifica" (ESPASIANI, 2016, p.117).

Comparando os dados das modinhas iguais é possível mapear a circulação buscando informações como: onde foi publicada, onde foi colhida, qual o ano da publicação, nome do compositor, poeta e meios de expressão.

Os espaços geográficos, metrópole-colônia, cidade-interior, privado-público, salãoseresta e os aspectos socioeconômicos como nobre-plebeu, burguês-proletário, rico-pobre e suas relações foram importantes nesse processo e já estudadas e comentadas por pesquisadores como Andrade (1980), Araújo (1963), Kiefer (1977) Tinhorão (1990) e Veiga (1997). Com base em Chartier buscamos descobrir outras relações como a relação de gênero no processo de interpretação das modinhas.

"Não é um princípio teórico, mas ao estudar as formas particulares de circulação e de apropriação culturais, conclui-se que conforme os períodos a diferença mais importante nem sempre é a diferença socioeconômica. A diferença entre homens e mulheres ou entre crenças religiosas pode ser a matriz de usos e apropriações diversos" (CHARTIER, 2001, p.66).

Tinhorão expõe que, até o aparecimento da modinha não havia um gênero de canção capaz de atender à nova demanda de aproximação entre os sexos, ocasionada pela recente estruturação da população nas cidades, embora cite o depoimento do francês M. de La Barbinais, em Salvador, 1718, no qual e relatado que portugueses saíram vestidos de roupões com seus rosários no pescoço e suas espadas e postaram-se debaixo das janelas de suas amadas. Cantaram com "voz ridiculamente terna cantigas que faziam lembrar música chinesa, 
ou as nossas gigas da Baixa Bretanha"(BARBINAIS in TINHORÃO,1990, p.92).

A modinha, portanto, nesse ambiente público, aparece como veículo de expressão dessa nova demanda do eu lírico masculino. Observando o conteúdo temático das modinhas podemos perceber a presença do eu lírico feminino nas modinhas de salão, modinhas essas que teoricamente, seriam para execução em ambientes privados: mas, raramente, nas modinhas de seresta. Paulo Pimenta de Mello, observa que era comum se falar nas cidades brasileiras, no século XX, de serenata como "coisa de homem" e ouvir serenata como "coisa de mulher"; e que ninguém tinha conhecimento de uma mulher seresteira empunhando violão sob a janela dos amados. Ele destaca que samba, blues e samba-canção eram os gêneros "permitidos" de serem gravados por mulheres. A maior parte das gravações de modinhas e serestas do início do século XX foram feitas por intérpretes masculinos. Convém lembrar que a presença de cantoras no período inicial das gravações, antes da era do rádio, era bem menor. Ser artista profissional não era atividade permitida à uma moça de "família" e estava no mesmo patamar das prostitutas. Poucas mulheres, com Pepa Delgado, Júlia Martins e Abigail Maia enfrentaram o preconceito vigente na época e atuaram como atrizes e cantoras (MELLO, 1985, p.16).

Observamos, portanto, que a influência desse fluxo e refluxo no cenário musical do Brasil tanto quanto na construção de novas concepções culturais em que a modinha esteve inserida por séculos, apresenta-se em aspectos geográficos, socioeconômicos, bem como em questões de gênero. Ressaltamos, também, as relações entre tradição oral e escrita como apontam os pesquisadores Ulhôa e Veiga.

Um dos caminhos apontados por Ulhôa, com base em suas pesquisas, no estudo do repertório ligados à tradição oral, é a descrição de características marcantes para tentar compreender as principais estruturas. Observam-se padrões de organização de seção, esquema de rima, estrutura métrica da letra, padrões rítmicos, comparação do texto. "Nos estudos de repertórios nacionais de canções folclóricas, chegou-se a considerar a existência de famílias de canções, presumivelmente derivadas de uma fonte única[...]", portanto acreditamos que esse também poderia ser um caminho para a comparação de algumas modinhas que possuam autoria em documento escrito (ULHÔA, 2008, p.6).

Veiga, em seus textos, O Estudo da Modinha Brasileira (1997) e Achegas para um Sarau de Modinhas Brasileiras (1998) e Impressão musical na Bahia (2004) vem demostrando empenho na revisão bibliográfica existente, na interação da musicologia histórica com a performance, na busca e na edição de partituras e no questionamento nos 
processos de transmissão oral e escrito. Veiga, citando Charles Seeger, conclui que, para o ensino e aprendizado de música importa mais a relação entre o oral e o escrito do que a diferença entre eles. Essa dicotomia entre oral e escrito foi permeando parte das publicações, tendo um grupo de publicações mais próximas de Guilherme de Mello e outro mais próximas de Mário de Andrade, respectivamente. Em Manuel da Veiga, parece começar a convergir para uma interação.

Chartier atenta que as delimitações entre oral e escrito não podem se basear apenas em oposições como abordagem externa-análise interna e coletivo-individualizado. Para ele, "a atribuição social das práticas culturais designadas até então como populares é agora pensada de maneira mais complexa". As coletâneas de modinhas de serestas seriam como a literatura de cordel, citada pelo autor, que é produzida por profissionais da escrita e da impressão, mas a partir da tradição oral (CHARTIER, 2002, p.26).

Como sugere Susana Igayara-Souza, essa dificuldade de delimitação aparece também na construção das coletâneas, uma vez que "tem muitas informações sobre a representação do mundo social" nessas produções. Observa ainda que em coletâneas é possível perceber os conceitos de Chartier nos ordenamentos e divisões, bem como nas escolhas. Atenta que "a noção de representação tem servido justamente para demonstrar que os discursos não são neutros" (IGAYARA-SOUZA, 2011, p.44).

Na história da música do Brasil podemos perceber coletâneas de canções infantis, de canções folclóricas, de hinos que visavam além da preservação da memória, inserir o papel da canção como educação musical ou educação moral e cívica. As coletâneas de modinha não tiveram objetivos educacionais e embora no final do século XVIII, tenham sido compostas com o objetivo de alcançar cantoras diletantes, não se estabeleceu esse caráter educacional.

As modinhas estão inseridas em diferentes tipos de coletâneas. Podemos dividir em dois grupos. O primeiro formado por coletâneas de modinhas impressas e o segundo formado por coletâneas que foram recolhidas da tradição oral. Atentamos que, após as publicações ambas passaram a fazer parte da cultura escrita. Observamos que em quase todas as coletâneas, foi expresso o propósito de contribuir para uma memória coletiva.

Chartier expõe que "passagem de um sistema de representação a outro pode, desde logo, ser entendida simultaneamente com uma ruptura radical"(CHARTIER,2001, p.52). É possível passar do oral para o escrito sem ruptura? E o retorno, do escrito para o oral na construção da interpretação ?

Ao final desse capítulo ampliaremos essa percepção, com a análise de duas obras, uma 
de salão Róseas flores d'alvorada e uma de seresta Amo-te muito, atentando não só na observação da coletânea a que pertence cada uma, a sua autoria, o meio de expressão escolhido, como também os processos de circulação no tempo e no espaço. Além do que já foi citado, também será observada a interpretação, por meio da escuta, buscando perceber as escolhas estilísticas e musicais.

3.2 Exemplos de obras que circularam

Abordaremos os três primeiros exemplos para observarmos os processos de circulação.

Tabela 9- Exemplos de obras que estão presentes em diversas fontes

\begin{tabular}{|c|c|c|}
\hline Rótulos de Linha & $+t$ & Contagem de Fonte \\
\hline Ao luar & & 11 \\
\hline Serenata & & 9 \\
\hline O Poeta e a Fidalga & & 8 \\
\hline
\end{tabular}

Fonte: Lista de modinhas

O título Ao luar aparece em 11 fontes. Observando a primeira frase percebemos que, na verdade são 5 obras com o mesmo título. As obras que aparecem nos livros Mysterios do Violão, Modinhas e A modinha no Grão -Pará não serão analisadas, pois não aparecem em circulação. Restam duas obras, uma que aparece em 2 fontes e outra que aparece em 6 fontes.

Ao Luar, que inicia com a frase Astros celestes, está em duas coletâneas. 
Tabela 10- Informações da modinha Ao Luar

\begin{tabular}{|c|c|c|c|c|}
\hline Título & Primeira frase & Compositor $\nabla$ & Poeta & Fonte \\
\hline Ao luar & \multicolumn{2}{|c|}{ Aos sons das violas, ó sertan Desconhecido } & Desconhecido & Mysterios do violão \\
\hline Ao luar & \multicolumn{2}{|c|}{ Astros celestes docemente lc Desconhecido } & Auta de Souza & Modinhas do Passado \\
\hline Ao luar & \multicolumn{2}{|c|}{ Astros celestes, docemente I Desconhecido } & Auta de Souza & As mais belas modinhas Vol. II \\
\hline Ao luar & Olha a lua como é bela! & $\begin{array}{l}\text { Paixão } \\
\text { Cearense }\end{array}$ & Catullo da Paixão & IModinhas \\
\hline Ao luar & Que serenidade & Desconhecido & Desconhecido & A modinha no Grão-Pará \\
\hline Ao luar & Vê que amenidade & Desconhecido & Desconhecido & Serenatas e Saráus III \\
\hline Ao luar & Vê que amenidade & Desconhecido & Desconhecido & Canções populares do Brazil \\
\hline Ao luar & Vê que amenidade & Desconhecido & Desconhecido & $\begin{array}{l}\text { Cancioneiro Popular de } \\
\text { modinhas brasileiras }\end{array}$ \\
\hline Ao luar & Vê que amenidade & $\begin{array}{l}\text { Catullo da } \\
\text { Paixão } \\
\text { Cearense }\end{array}$ & $\begin{array}{l}\text { Catullo da Paixão } \\
\text { Cearense }\end{array}$ & Modinhas antigas \\
\hline Ao luar & Vê que amenidade & $\begin{array}{l}\text { Catullo da } \\
\text { Paixão } \\
\text { Cearense }\end{array}$ & $\begin{array}{l}\text { Catullo da Paixão } \\
\text { Cearense }\end{array}$ & Modinhas \\
\hline Ao luar & Vê que amenidade, que serer & $\begin{array}{l}\text { Catullo da } \\
\text { Paixão } \\
\text { Cearense }\end{array}$ & $\begin{array}{l}\text { Catullo da Paixão } \\
\text { Cearense }\end{array}$ & As mais belas modinhas \\
\hline
\end{tabular}

Fonte: Lista de modinhas 


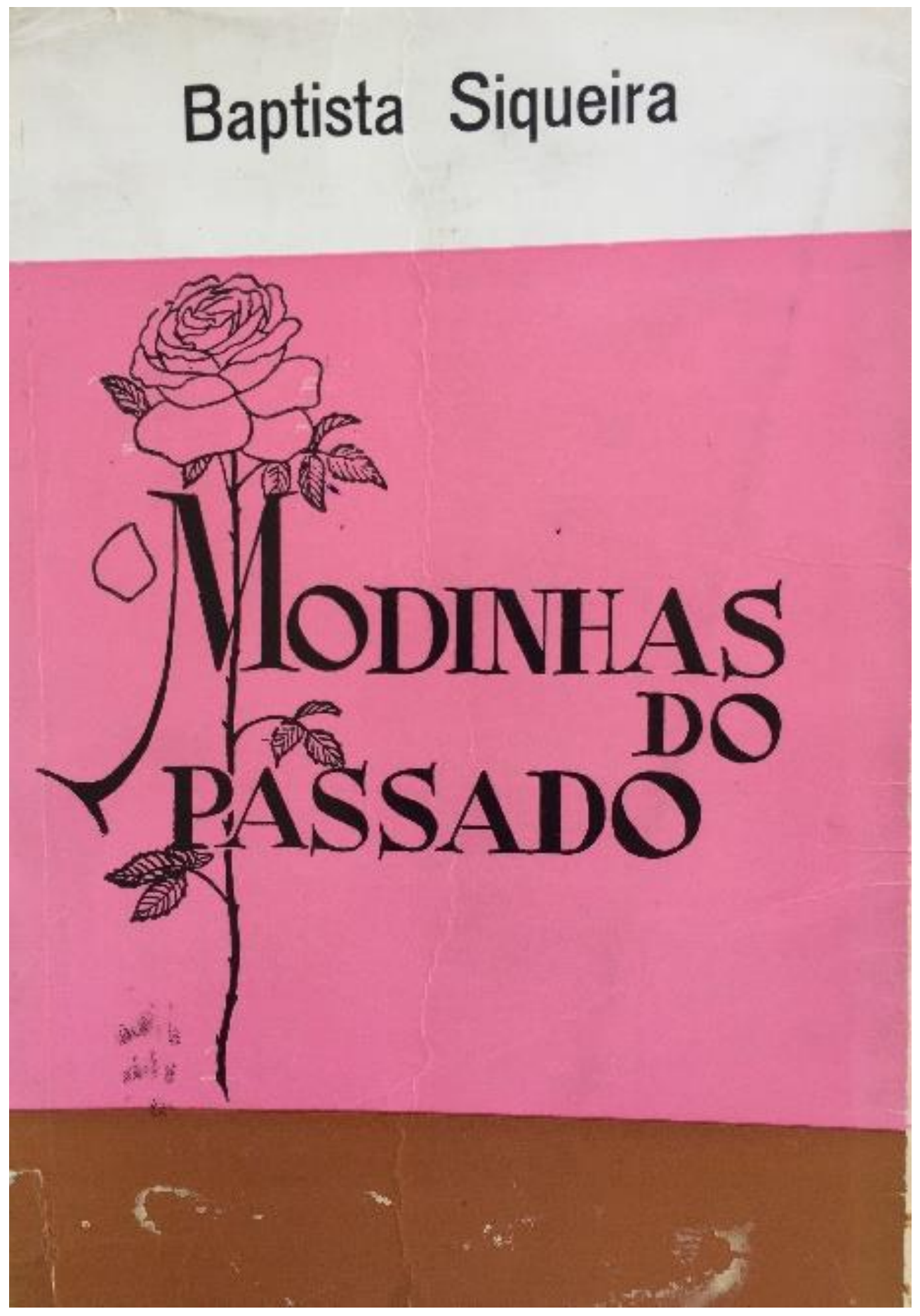

Fonte : Modinhas do passado 
Figura 17- Partitura da modinha Ao Luar

\section{AO LUAR *}

Modinha com versos de Auta de Souza - Do livro Horto. Foi dedicada à Maria Fausta e Mercedes Coelho, em 1898

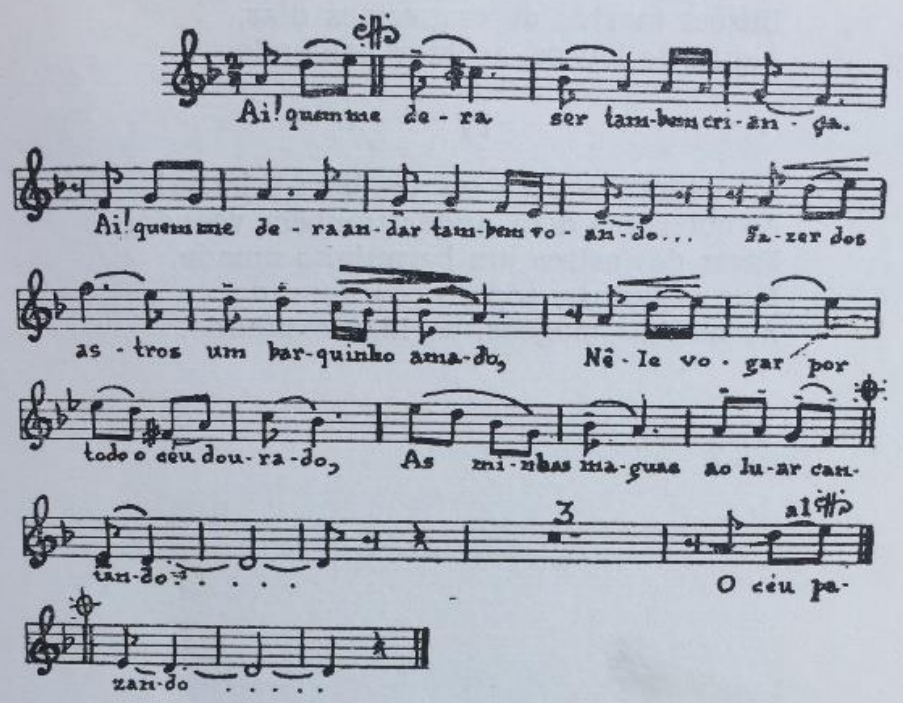

I

Astros celestes, docemente louros Giram no espaço, em luminoso bando Ouve-se ao longe um violão plangente $\mathrm{E}$, mais além, num soluçar dolente... Canções serenas, ao luar cantando.

\section{II}

O céu parece uma igrejinha antiga

Que a lua branca vai iluminando...

$\mathrm{E}$ essas estrelas, muito além dispersas,

São rosas brancas, no infinito imersas,

Monjas benditas, ao luar rezando...

Aqui é a versão popular, aparecendo com pequenas modificaçóes do original da autora norte-rio-grandense. O livro da grande poetisa, é

$$
-175-
$$

Fonte : Modinhas do passado 
Os pirilampos, pelas moitas tristes, Voam calados e sutis, brilhando... Lembram descrenças, a bailar sombrias, Ilusões mortas de esquecidos dias, Almas de loucos, ao luar passando...

\section{IV}

Ai! quem me dera ser também criança! Ai quem me dera andar também voando! Fazer dos astros um barquinho amado, Nele vogar por todo o céu dourado, As minhas mágoas, ao luar cantando.

Fonte : Modinhas do passado

A versão apresentada na coletânea As mais belas modinhas Vol. II tem a mesma 
melodia da versão apresentada no livro Modinhas do Passado. Embora a autora não cite a fonte de Siqueira ela inclui o livro na bibliografia. O livro de Siqueira possui as mesmas quatro letras apresentadas por Maurício; porém, a letra que está escrita na linha melódica não foi repetida na coletânea de Maurício.

Ilustração 7- Capa do livro As mais belas modinhas II

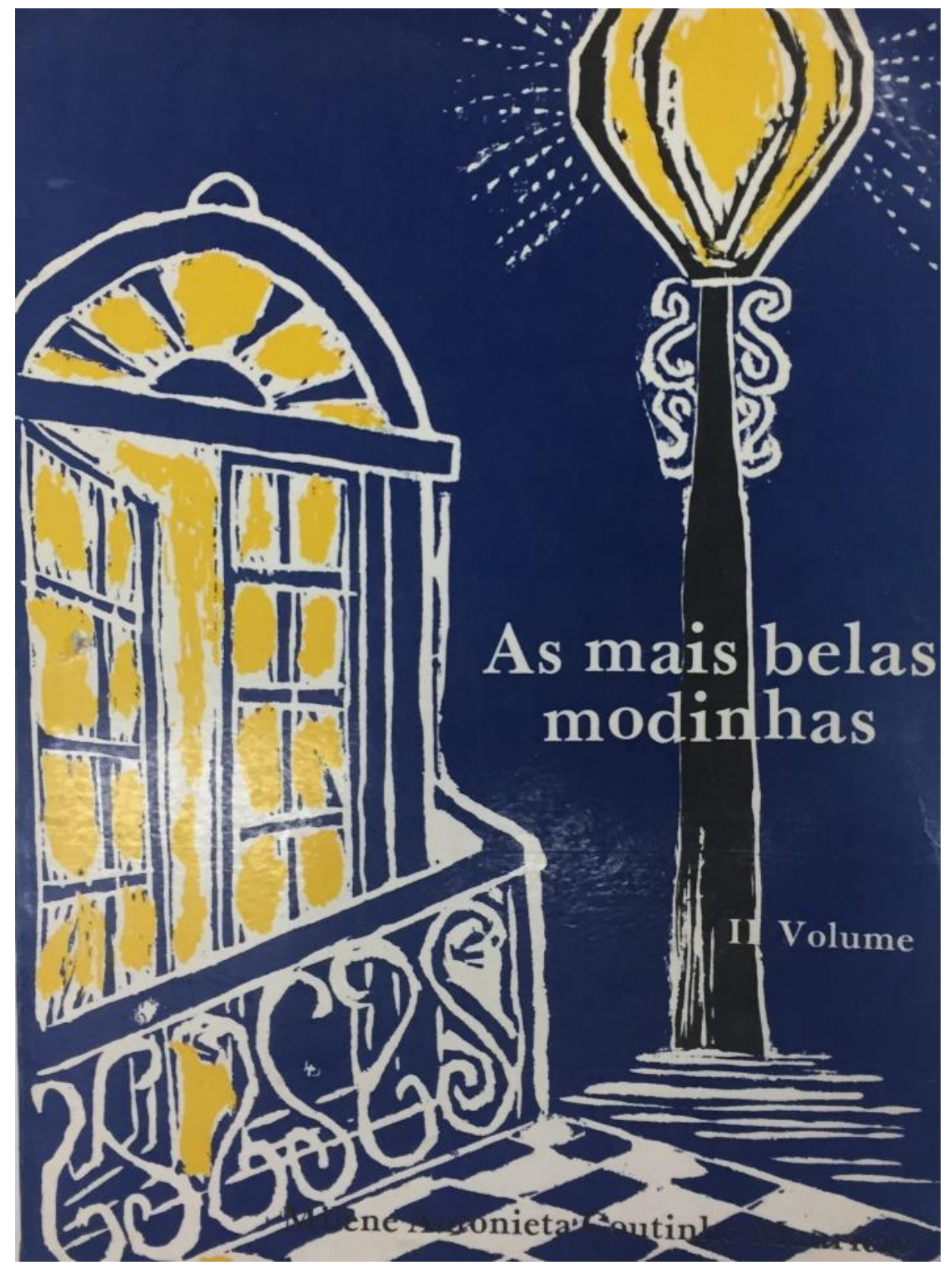

Fonte: As mais belas modinhas II 


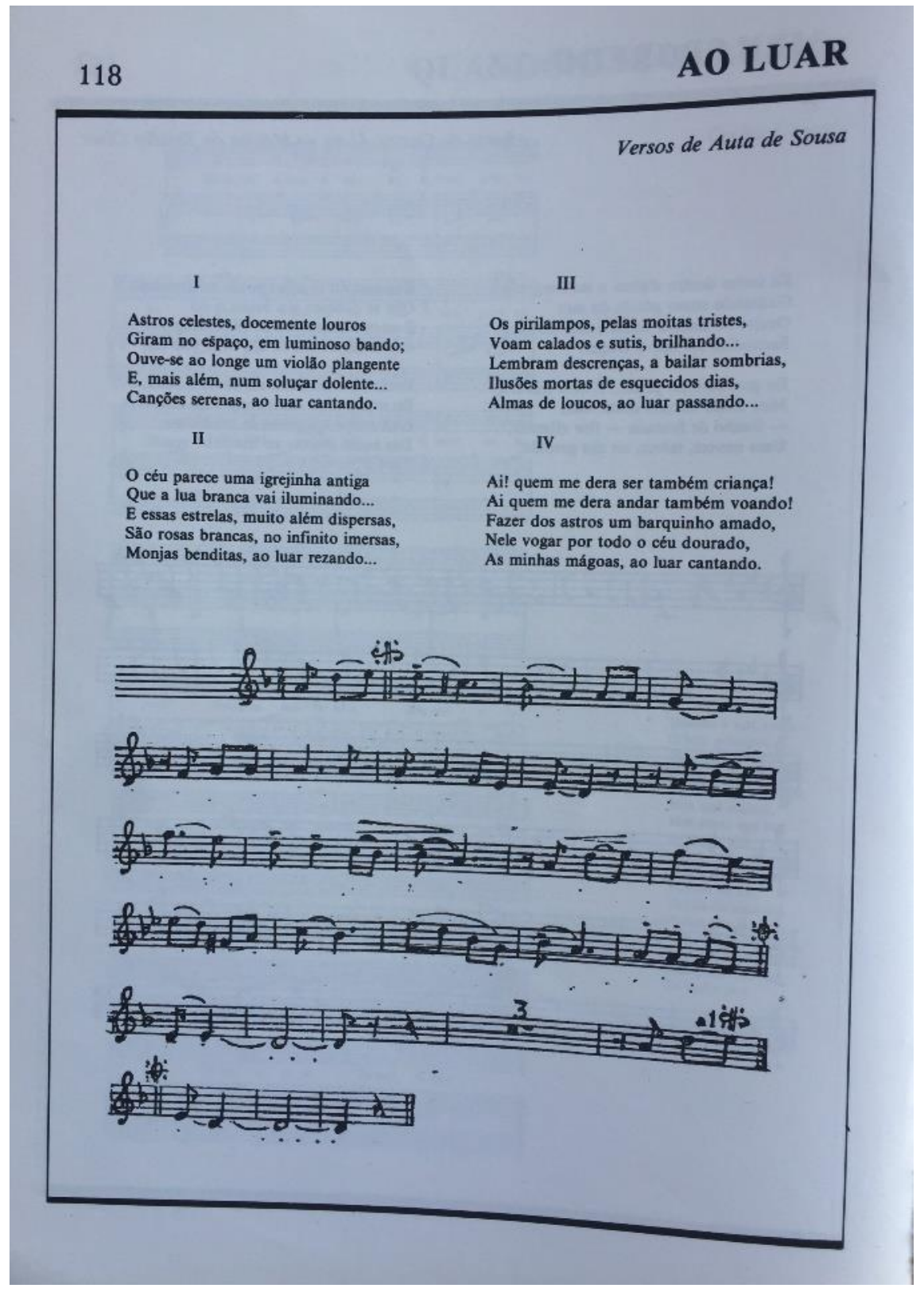

Fonte: As mais belas modinhas II

A modinha Ao Luar que inicia com a frase Vê que amenidade aparece em seis fontes conforme quadro abaixo: 
Tabela 11- Ordem cronológica das fontes da modinha Ao Luar

\begin{tabular}{|l|l|l|}
\hline & FONTE & $\begin{array}{l}\text { ANO DA PRIMEIRA } \\
\text { PUBLICAÇÃO }\end{array}$ \\
\hline A & Cancioneiro Popular de modinhas brasileiras & 1899 \\
\hline B & Serenatas e Saraús III & 1902 \\
\hline C & Canções Populares do Brasil & 1911 \\
\hline D & Modinhas & 1943 \\
\hline E & As mais belas modinhas & 1976 \\
\hline F & Modinhas Antigas & 1980 \\
\hline
\end{tabular}

Fonte: Lista de coletâneas

Cancioneiro popular de modinhas brasileiras, Serenatas e Saráus III e Modinhas possuem apenas a letra. Nos dois primeiros não aparece autoria. Na coletânea Modinhas ela aparece com autoria de Catullo da Paixão Cearense. Interessante pensar que o Cancioneiro Popular de Modinhas Brasileiras tem organização de Catullo da Paixão e nesse volume ele não indica a sua autoria; 
Ilustração 8- Capa do livro Cancioneiro popular de modinhas brasileiras

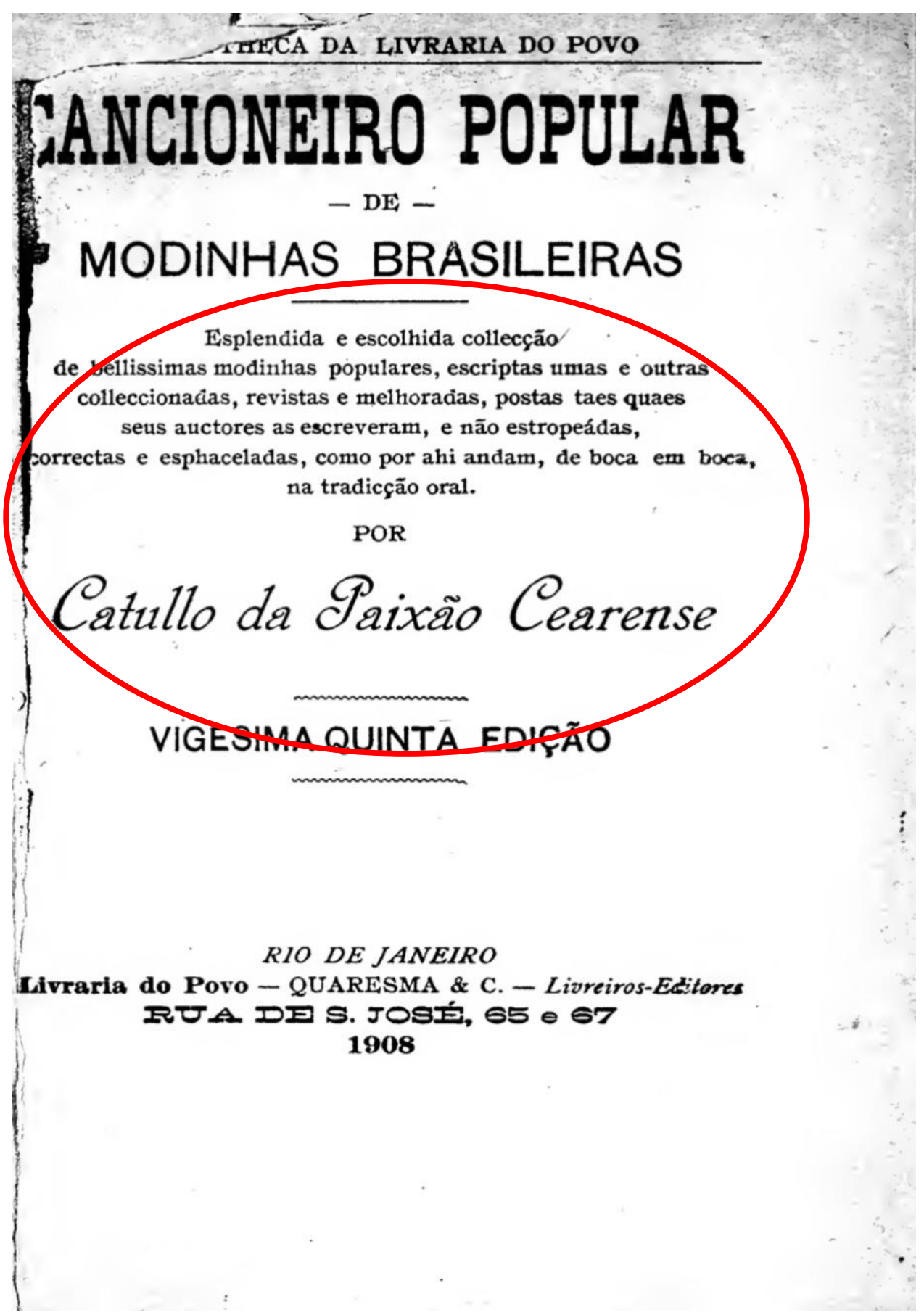

Fonte: Cancioneiro popular de modinhas brasileiras 
O texto se manteve quase idêntico em todas as edições, ocorrendo as adequações da língua e pequenas alterações, conforme demonstrado na tabela abaixo:

Tabela 12- Letras da modinha Ao Luar nas fontes A,B e D.

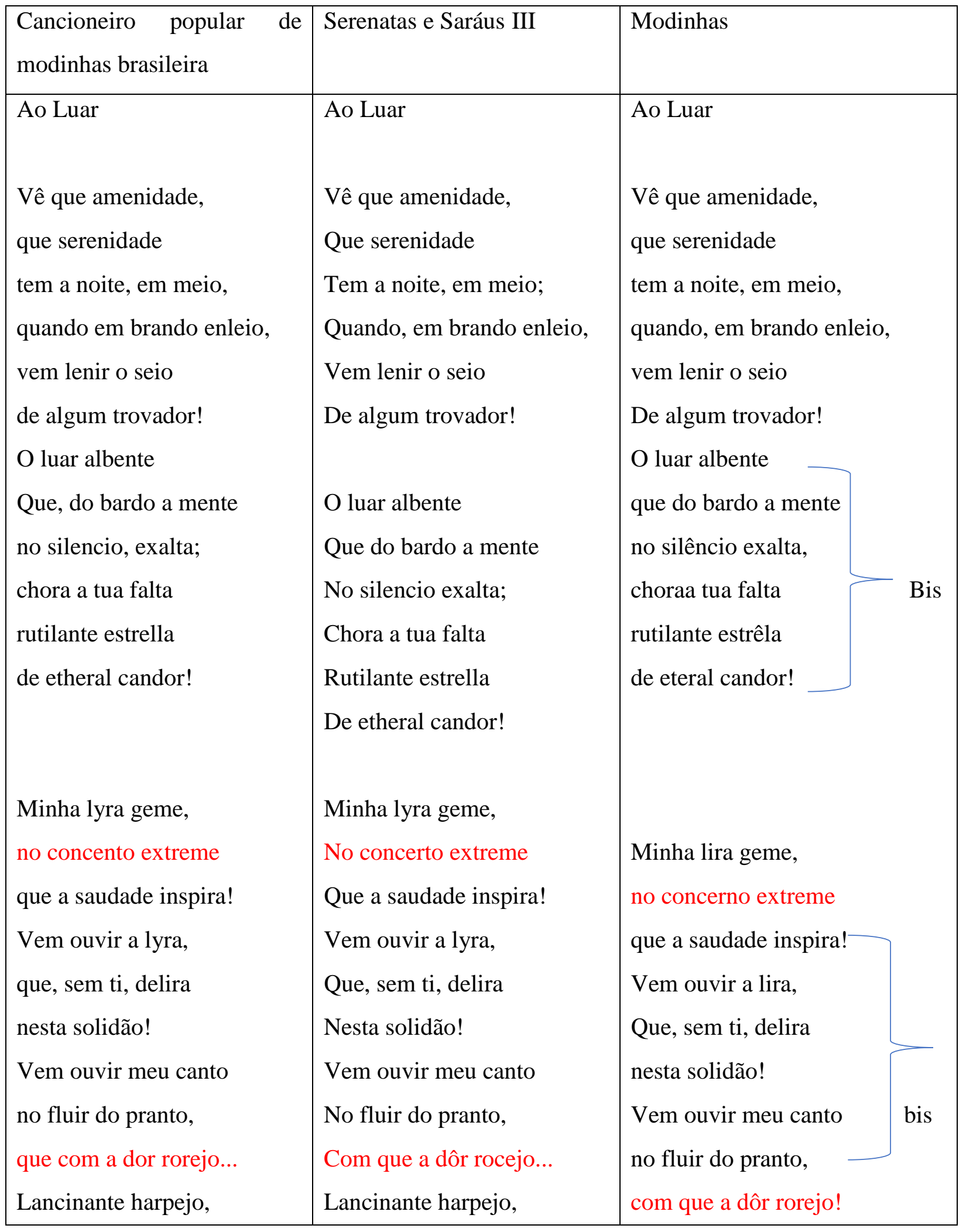




\begin{tabular}{|c|c|c|c|}
\hline $\begin{array}{l}\text { Que das fibras tanjo } \\
\text { deste coração! }\end{array}$ & $\begin{array}{l}\text { Que das fibras tanjo } \\
\text { Deste coração! }\end{array}$ & $\begin{array}{l}\text { Lancinanteharpejo, } \\
\text { que das fibras tanjo } \\
\text { deste coração! }\end{array}$ & Bis \\
\hline Vem, meu anjo, agora, & Vem, meu anjo, agora, & & \\
\hline recordar nest'hora & Recordar nest'hora & Vem, meu anjo, agora, & \\
\hline nosso amor fanado, & Nosso amor fanado, & recordar nest'hora & \\
\hline quando, eu a teu lado, & Quando eu a teu lado, & nosso amor fanado, & \\
\hline mais que aventurado, & Mais que aventurado, & quando eu a teu lado, & \\
\hline por te amar vivi! & Por te amar vivi! & mais que aventurado, & \\
\hline Quero a fronte tua & Quero a fronte tua & por te amar vivi! & \\
\hline ver à luz da lua & Vêr a luz da lua & Quero a fronte tua & \\
\hline resplendente e bella!... & Resplendente e bela!... & Ver à luz da lua & \\
\hline Descerra a janella, & Descerra a janela, & resplendente e bela!... & \\
\hline que soluça o estro & Que soluça o estro & Descerra a janela, & Bis \\
\hline só pensando em ti! & Só pensando em ti! & que eu não durmo as noites, & \\
\hline & & só pensando em ti! & \\
\hline Dá-me um teu conforto, & Dá-me um teu conforto, & & \\
\hline que esse affecto é morto & Que esse affecto é morto & Dá-me um teu confôrto, & \\
\hline que me consagravas... & Que me consagravas... & que êsse afeto é morto & \\
\hline quando protestavas & Quando protestavas & que me consagravas... & \\
\hline quando me juravas, & Quando me juravas, & quando protestavas & \\
\hline eviterno amor! & Eviterno amor! & quando me juravas, & \\
\hline Vem um só momento & Vem um só momento & eviterno amor! & \\
\hline dar ao pensamento & Dar ao pensamento & Vem um só momento & \\
\hline radiosa imagem; & Uma estellante imagem; & dar ao pensamento & \\
\hline depois, na miragem, & Depois, na miragem, & radiosa imagem; & \\
\hline deixa, em tua ausência, & Deixa, em tua ausência, & depois, na miragem, & \\
\hline cruciar-me a dor! & Cruciar-me a dôr! & $\begin{array}{l}\text { deixa, em tua ausência, } \\
\text { cruciar-me a dôr! }\end{array}$ & \\
\hline Da saudade o dardo & Da saudade o dardo & & \\
\hline vem ferir o bardo & Vem ferir o bardo & Da saudade o dardo & \\
\hline o coração silente! & O coração silente! & vem ferir o bardo & \\
\hline
\end{tabular}




\begin{tabular}{|c|c|c|c|}
\hline Esta dor latente & Esta dôr latente & o coração silente! & \\
\hline só na campa algente & Só na campa algente & Esta dor latente & \\
\hline poderá findar! & Poderá findar! & só na campa algente & \\
\hline Mas, si ainda o peito & Mas, si ainda o peito & poderá findar! & \\
\hline palpitar no leito & Palpitar no leito & Mas, si ainda o peito & \\
\hline de eternal abrigo... & De eternal abrigo... & palpitar no leito - & \\
\hline hei de, só, comtigo, & Hei de, só, comtigo, & de eternal abrigo... & \\
\hline sob a lousa, sem somno & Sob a lousa, sem somno & hei de, só, contigo, & Bis \\
\hline \multirow[t]{2}{*}{ funeral, sonhar! } & Funeral, sonhar! & sob a lousa, sem sono & \\
\hline & & funeral, sonhar! & \\
\hline
\end{tabular}

Fonte: Coletâneas A,B e D

As letras presentes nas coletâneas juntamente com as partituras são

Tabela 13- Letras da modinha Ao Luar nas fontes C,E e F

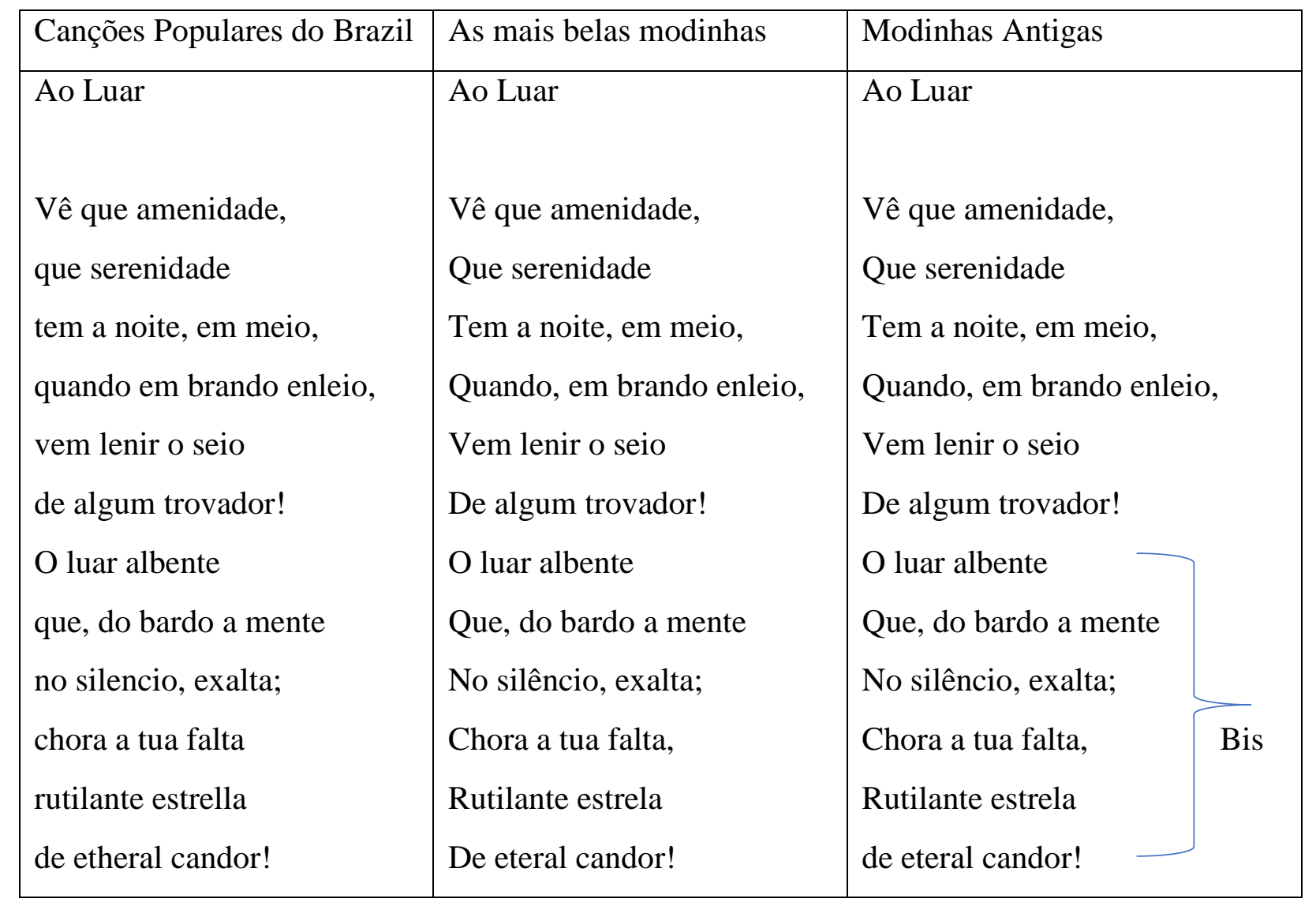




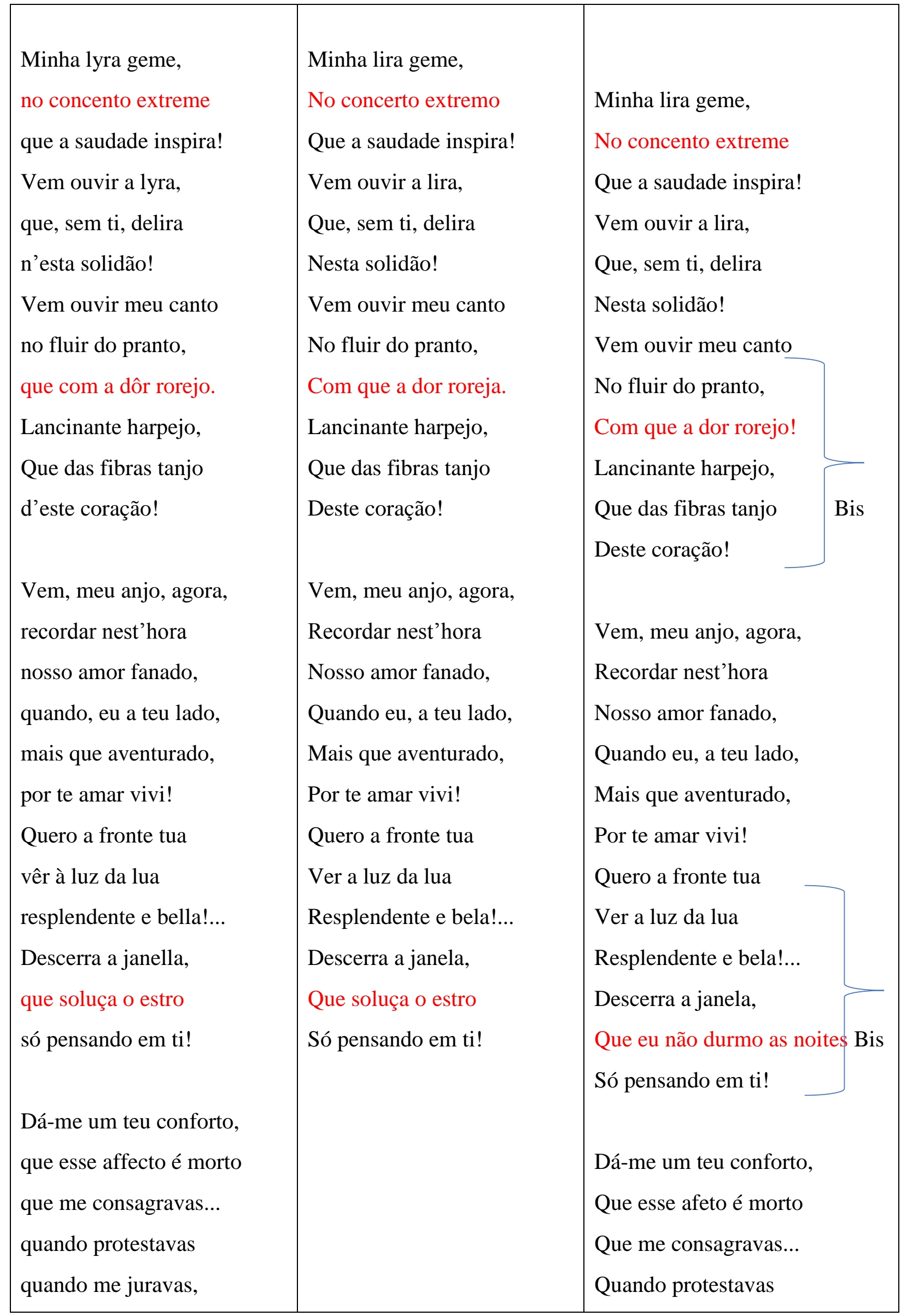




\begin{tabular}{|c|c|c|}
\hline eviterno amor! & Quando me juravas, & \\
\hline Vem um só momento & Eviterno amor! & \\
\hline dar ao pensamento & Vem um só momento & \\
\hline radiosa imagem; & Dar ao pensamento & \\
\hline depois, na miragem, & Radiosa imagem; & \\
\hline deixa, em tua ausencia, & Depois, na miragem, & \\
\hline cruciar-me a dôr! & $\begin{array}{l}\text { Deixa, em tua ausência, } \\
\text { Cruciar-me a dor! }\end{array}$ & BIS \\
\hline Da saudade o dardo & & \\
\hline vem ferir o bardo & Da saudade o dardo & \\
\hline o coração silente! & Vem ferir o bardo & \\
\hline Esta dôr latente & O coração silente! & \\
\hline só na campa algente & Esta dor latente & \\
\hline poderá findar! & Só na campa algente & \\
\hline Mas, si ainda o peito & Poderá findar! & \\
\hline palpitar no leito & Mas, si ainda o peito & \\
\hline de eternal abrigo... & Palpitar no leito & \\
\hline hei-de, só, comtigo, & De eternal abrigo... & \\
\hline sob a lousa, sem somno & Hei de, só, contigo, & \\
\hline \multirow[t]{2}{*}{ funeral, sonhar! } & Sob a lousa, sem sono & BIS \\
\hline & Funeral, sonhar! & \\
\hline
\end{tabular}

Fonte: Coletâneas C,E e F 
As partituras escritas da linha melódica também são bem parecidas, apresentando apenas variação de duração e altura nos trechos assinalados.

Figura 20- Partitura da modinha Ao Luar

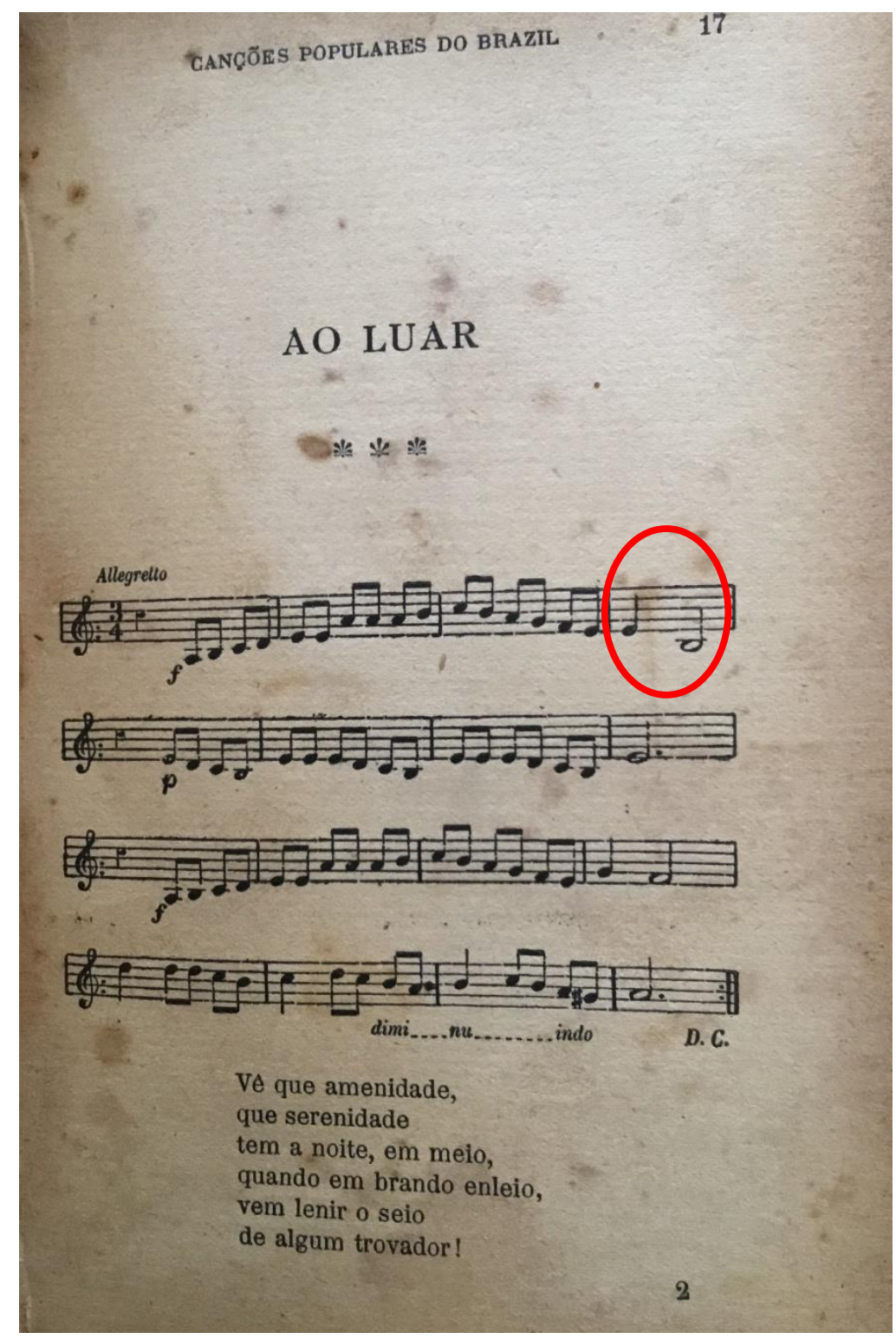

Fonte: Canções populares do Brazil 
Tabela 14- Compassos 4 e 5 da modinha Ao Luar na fonte $C$

\begin{tabular}{|l|l|l|}
\hline Compasso 4 & & Compasso 5 \\
\hline mi - semínima & si- mínima & $\begin{array}{l}\text { Inicia com pausa de } \\
\text { semínima }\end{array}$ \\
\hline
\end{tabular}

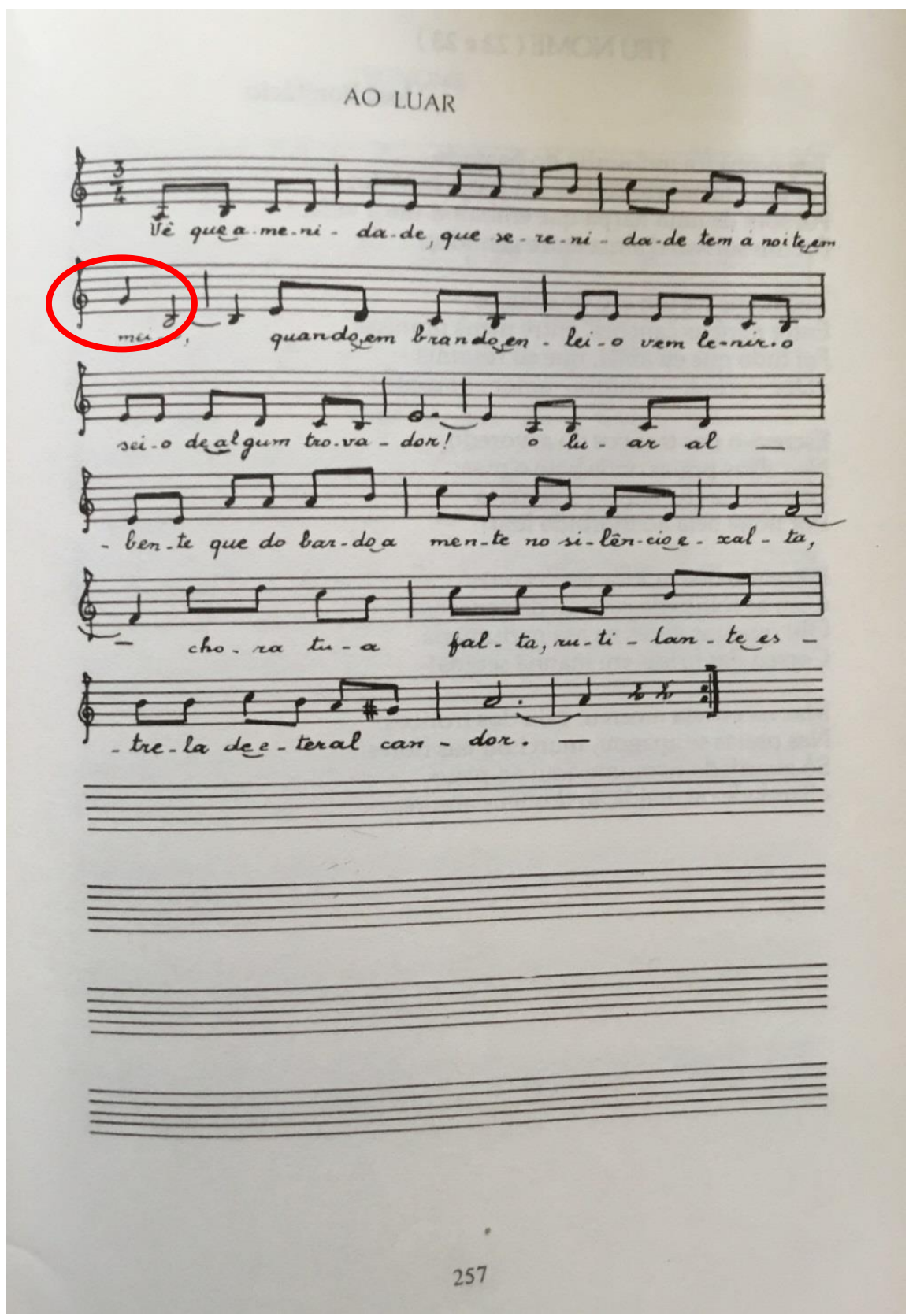

Fonte: Modinhas Antigas 
Tabela 15- Compassos 4 e 5 da modinha Ao Luar na fonte F

\begin{tabular}{|l|l|l|}
\hline Compasso 4 & Compasso 5 \\
\hline sol - semínima & si- mínima com ligadura & inicia com semínima \\
\hline
\end{tabular}

\section{An luar}

Vê que amenidade, que serenidade

Tem a noite, em meio,

Catulo da Paixão Cearense

Quando em brando enleio,

Vem lenir o seio

De algum trovador!

O luar albente

Que, do bardo a mente

No silêncio, exalta,

Chora a tua falta,

Rutilante estrela

De eteral candor!

Minha lira geme,

Vem, meu anjo, agora,

No concerto extremo

Recordar nest'hora

Que a saudade inspira!

Nosso amor fanado,

Vem ouvir a lira,

Quando eu, a teu lado.

Que, sem ti, delira

Nesta solidão!

Mais que aventurado.

Por te amar vivi!

Vem ouvir meu canto

No fluir do pranto,

Quero a fronte tua

Com que a dor roreja.

Ver a luz da lua

Lascinante harpejo

Que das fibras tanjo

Deste coração!

Resplendente e bela!. .

Descerra a janela,

Que soluça o estro

Só pensando em ti!

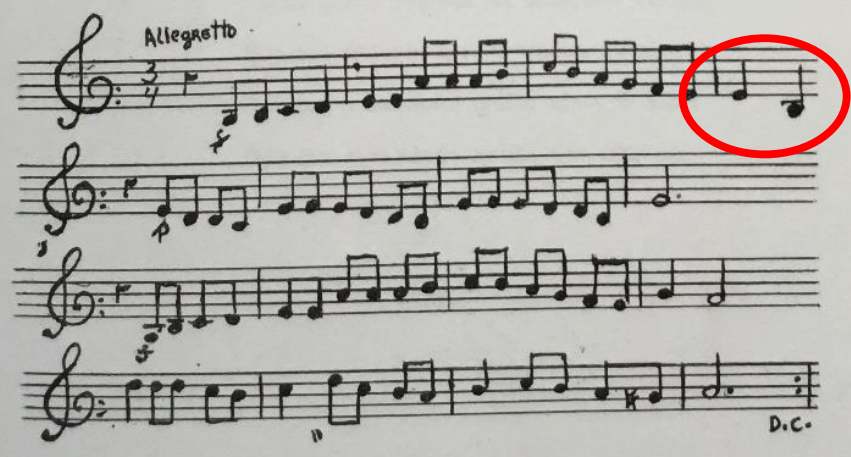


Tabela 16- Compassos 4 e 5 da modinha Ao Luar na fonte E

\begin{tabular}{|l|l|l|}
\hline Compasso 4 & & Compasso 5 \\
\hline mi - semínima & si- semínima & inicia com pausa de semínima \\
\hline
\end{tabular}

Como o compasso é ternário acreditamos que tenha sido um erro de grafia. $\mathrm{O}$ si deveria ser uma mínima para completar os três tempos, como na escrita do Canções Populares do Brazil.

A modinha Serenata, que consta na lista como presente em 9 fontes, na verdade, não é a mesma música. Após a comparação da primeira frase, que é segundo campo da tabela, percebemos que existem 7 obras com o mesmo título; portanto, não houve, de fato, uma circulação da Serenata em tantas fontes, conforme a tabela abaixo. Diante disso, optamos por analisar o exemplo seguinte na lista.

Tabela 17- Informações da música Serenata

\begin{tabular}{|c|c|c|c|c|}
\hline Título $\mathbf{\nabla}$ & Primeira frase & Compositor & Poeta & Fonte \\
\hline Serenata & $\begin{array}{l}\text { Aos frouxos raios da } \\
\text { lua, }\end{array}$ & $\begin{array}{l}\text { A. Cardoso de } \\
\text { Menezes }\end{array}$ & Desconhecido & $\begin{array}{l}\text { Canções populares do } \\
\text { Brazil }\end{array}$ \\
\hline Serenata & $\begin{array}{l}\text { Aos frouxos raios da } \\
\text { lua, }\end{array}$ & $\begin{array}{l}\text { A. Cardoso de } \\
\text { Menezes }\end{array}$ & $\begin{array}{l}\text { A. Cardoso de } \\
\text { Menezes }\end{array}$ & $\begin{array}{l}\text { As mais belas } \\
\text { modinhas Vol. II }\end{array}$ \\
\hline Serenata & $\begin{array}{l}\text { Dorme, fecha este olhar } \\
\text { entardescente }\end{array}$ & $\begin{array}{l}\text { Sylvio Caldas e } \\
\text { Orestes Barbosa }\end{array}$ & $\begin{array}{l}\text { Sylvio Caldas e } \\
\text { Orestes Barbosa }\end{array}$ & $\begin{array}{l}\text { Modinhas \& Serenatas } \\
\text { Valsas \& Canções }\end{array}$ \\
\hline Serenata & Murmura a briza fagueira & Desconhecido & Cardoso de Menezes & Serenatas e Saráus III \\
\hline Serenata & Murmura a briza fagueira & $\begin{array}{l}\text { A. Cardoso de } \\
\text { Menezes }\end{array}$ & Desconhecido & $\begin{array}{l}\text { Canções populares do } \\
\text { Brazil }\end{array}$ \\
\hline Serenata & $\begin{array}{l}\text { Na Guanabara um barco } \\
\text { a vela navagava }\end{array}$ & Vicente Celestino & Vicente Celestino & $\begin{array}{l}\text { As mais belas } \\
\text { modinhas Vol. II }\end{array}$ \\
\hline Serenata & $\begin{array}{l}\text { Não sei porquê, nas } \\
\text { horas sossegadas }\end{array}$ & Desconhecido & EImano Queiroz & $\begin{array}{l}\text { A modinha no Grão- } \\
\text { Pará }\end{array}$ \\
\hline Serenata & Se em meio da noite & Desconhecido & Desconhecido & Serenatas e SaráusIII \\
\hline Serenata & Vem ó, vem & $\begin{array}{l}\text { Catullo da Paixão } \\
\text { Cearense }\end{array}$ & $\begin{array}{l}\text { Catullo da Paixão } \\
\text { Cearense }\end{array}$ & Modinhas \\
\hline
\end{tabular}

Fonte: Lista de modinhas

O poeta e a fidalga aparece em 8 fontes com o mesmo título, e após a comparação da primeira frase, observamos a mesma modinha em 7 fontes. A outra modinha que aparece no Livro Lyra Popular Brazileira é uma resposta à primeira.

O eu lírico da primeira é o poeta e o eu lírico da resposta é a fidalga. 
Tabela 18- Informações da música O Poeta e a Fidalga

\begin{tabular}{|c|c|c|c|c|}
\hline Título & - Primeira frase -1 & Compositor & - Poeta & Fonte \\
\hline O poeta e a Fidalga & $\begin{array}{l}\text { Bem sei mulher, } \\
\text { bem conheço }\end{array}$ & Heronides de França & $\begin{array}{l}\text { Segundo } \\
\text { Wesley }\end{array}$ & Modinhas antigas \\
\hline O poeta e a Fidalga & $\begin{array}{l}\text { Bem sei que tu me } \\
\text { desprezas, }\end{array}$ & Heronides de França & $\begin{array}{l}\text { Segundo } \\
\text { Wanderley }\end{array}$ & As mais belas modinhas \\
\hline O poeta e a Fidalga & $\begin{array}{l}\text { Bem sei que tu me } \\
\text { desprezas, }\end{array}$ & Heronides de França & $\begin{array}{l}\text { Segundo } \\
\text { Wanderley }\end{array}$ & A modinha no Grão-Pará \\
\hline O poeta e a Fidalga & $\begin{array}{l}\text { Bem sei que tu me } \\
\text { desprezas, }\end{array}$ & Desconhecido & Wanderley & Serenatas e Saráus III \\
\hline O poeta e a Fidalga & $\begin{array}{l}\text { Bem sei que tu me } \\
\text { desprezas, }\end{array}$ & Desconhecido & Desconhecido & Canções populares do Brazil \\
\hline O poeta e a Fidalga & $\begin{array}{l}\text { Bem sei que tu me } \\
\text { desprezas, }\end{array}$ & Desconhecido & Desconhecido & $\begin{array}{l}\text { Cancioneiro Popular de modinhas } \\
\text { brasileiras }\end{array}$ \\
\hline O poeta e a Fidalga & $\begin{array}{l}\text { Bem sei, mulher, } \\
\text { bem conheço }\end{array}$ & Heronides de França & $\begin{array}{l}\text { Segundo } \\
\text { Wanderley }\end{array}$ & A modinha Norte-Rio-Grandense \\
\hline O poeta e a Fidalga & $\begin{array}{l}\text { Tu dizes que eu te } \\
\text { despréso, }\end{array}$ & Desconhecido & Desconhecido & Lyra popular brasileira \\
\hline
\end{tabular}

Fonte: Lista de modinhas

Tabela 19 - Ordem cronológica das fontes da modinha O poeta e a fidalga

\begin{tabular}{|l|l|l|}
\hline & FONTE & $\begin{array}{l}\text { ANO DA PRIMEIRA } \\
\text { PUBLICAÇÃO }\end{array}$ \\
\hline A & Cancioneiro Popular de modinhas brasileiras & 1899 \\
\hline B & Serenatas e Saraús III & 1902 \\
\hline C & Canções Populares do Brazil & 1911 \\
\hline D & As mais belas modinhas & 1976 \\
\hline E & Modinhas Antigas & 1980 \\
\hline F & A modinha Norte-rio-grandense & 2000 \\
\hline G & A modinha no grão-pará & 2005 \\
\hline
\end{tabular}

Fonte: Lista de coletâneas 
Tabela 20- Letras da modinha O poeta e a Fidalga nas fontes A,B e C

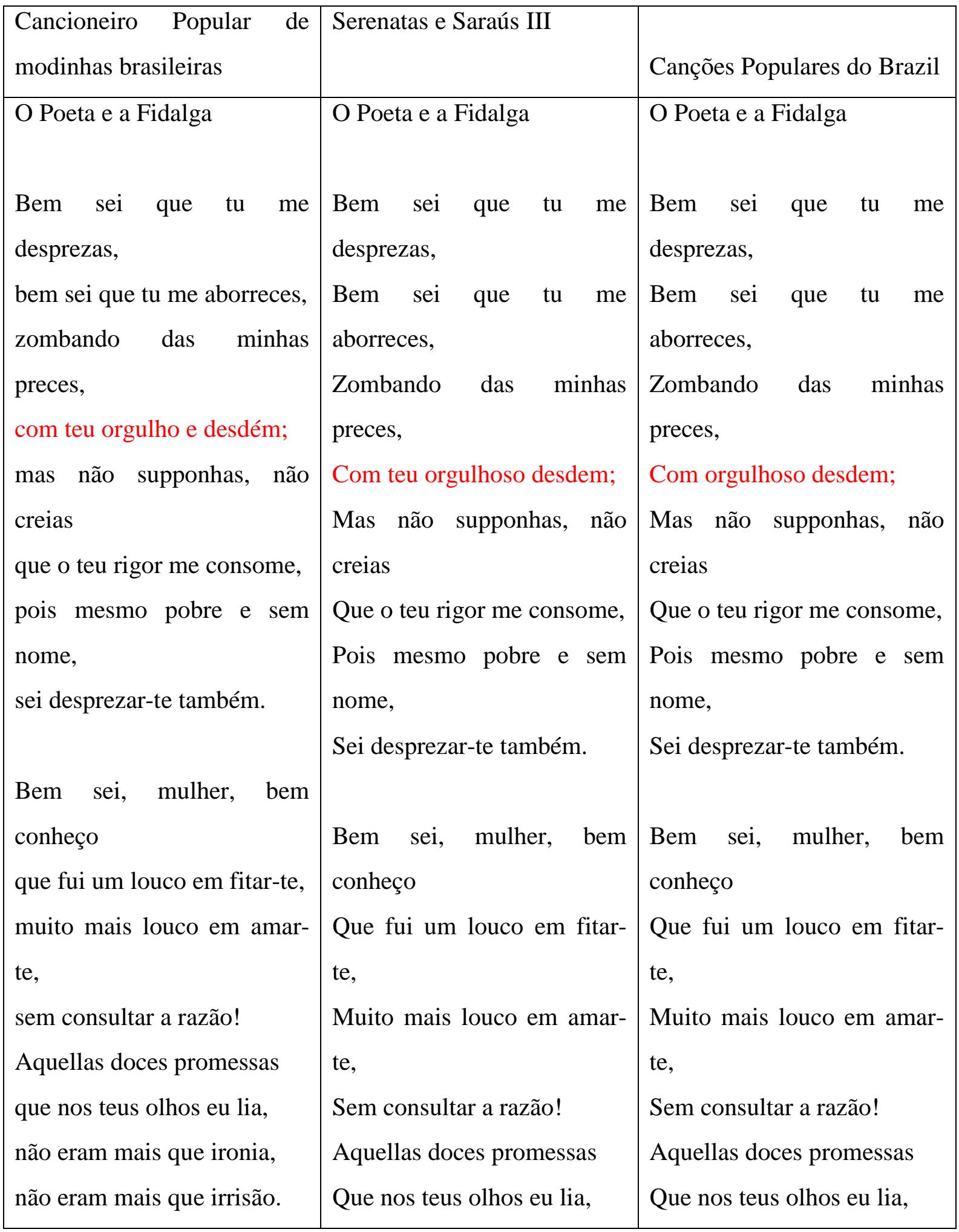




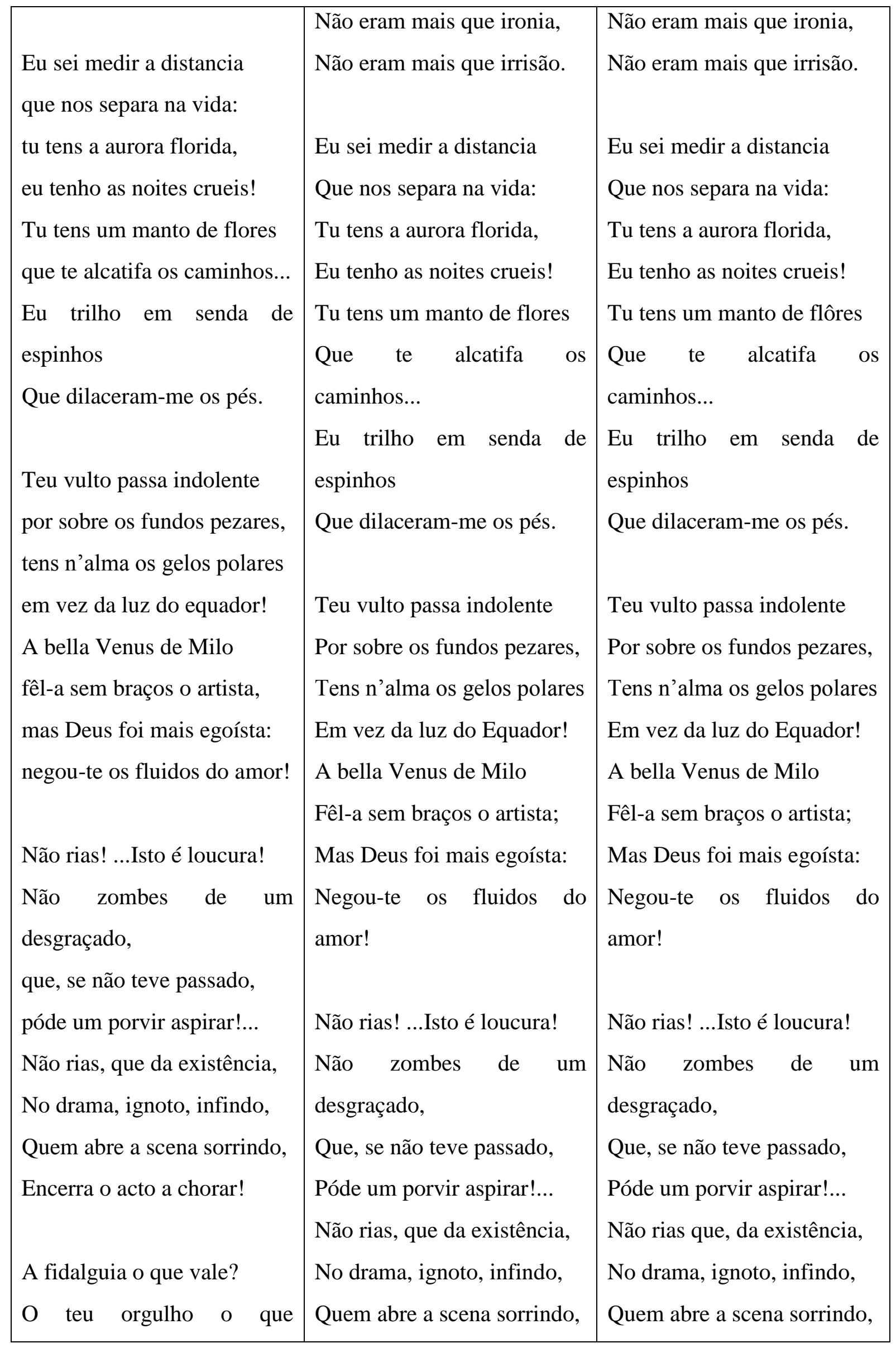




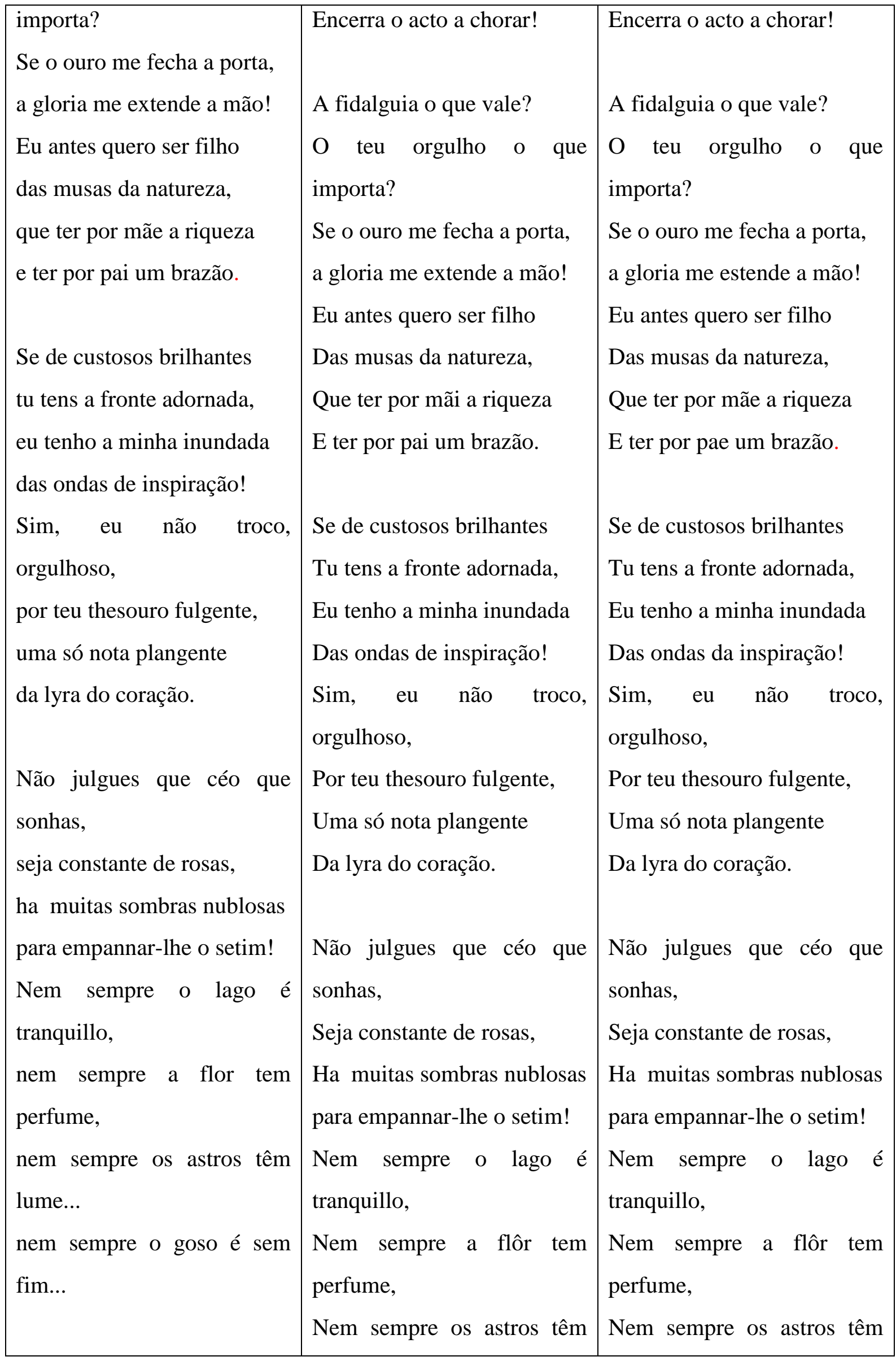




\begin{tabular}{|l|l|l|}
\hline & $\begin{array}{l}\text { lume? } \\
\text { Nem sempre o gozo é sem } \\
\text { fim. }\end{array}$ & $\begin{array}{l}\text { lume? } \\
\text { Nem sempre o gozo é sem } \\
\text { fim. }\end{array}$ \\
\hline
\end{tabular}

Tabela 21- Letras da modinha O poeta e a Fidalga nas fontes D,E,F e G

\begin{tabular}{|c|c|c|c|}
\hline $\begin{array}{l}\text { As mais belas } \\
\text { modinhas }\end{array}$ & Modinhas Antigas & $\begin{array}{l}\text { A modinha Norte- } \\
\text { rio-grandense }\end{array}$ & $\begin{array}{l}\text { A modinha no grão- } \\
\text { pará }\end{array}$ \\
\hline O Poeta e a Fidalga & O Poeta e a Fidalga & O Poeta e a Fidalga & O Poeta e a Fidalga \\
\hline $\begin{array}{l}\text { Bem sei que tu me } \\
\text { desprezas, }\end{array}$ & $\begin{array}{l}\text { Bem sei, mulher, bem } \\
\text { conheço }\end{array}$ & $\begin{array}{l}\text { Bem sei que tu me } \\
\text { desprezas, }\end{array}$ & $\begin{array}{l}\text { Bem sei que tu me } \\
\text { desprezas, }\end{array}$ \\
\hline $\begin{array}{l}\text { Bem sei que tu me } \\
\text { aborreces, }\end{array}$ & $\begin{array}{l}\text { Que fui um louco em } \\
\text { fitar-te, }\end{array}$ & $\begin{array}{l}\text { Bem sei que tu me } \\
\text { aborreces, }\end{array}$ & $\begin{array}{l}\text { Bem sei que tu me } \\
\text { aborreces, }\end{array}$ \\
\hline $\begin{array}{l}\text { Zombando das } \\
\text { minhas preces, }\end{array}$ & $\begin{array}{l}\text { Muito mais louco em } \\
\text { amar-te, }\end{array}$ & $\begin{array}{l}\text { Que zombas das } \\
\text { minhas preces, }\end{array}$ & $\begin{array}{l}\text { Zombando das } \\
\text { minhas preces, }\end{array}$ \\
\hline $\begin{array}{l}\text { Com orgulhoso } \\
\text { desdém; }\end{array}$ & $\begin{array}{l}\text { Sem consultar } \\
\text { razão! }\end{array}$ & $\begin{array}{l}\text { Com ostensivo } \\
\text { desdém: }\end{array}$ & $\begin{array}{l}\text { Com orgulhoso } \\
\text { desdém; }\end{array}$ \\
\hline $\begin{array}{l}\text { Mas não suponhas, } \\
\text { não creias }\end{array}$ & $\begin{array}{l}\text { Aquelas doces } \\
\text { promessas }\end{array}$ & $\begin{array}{l}\text { Mas não suponhas, } \\
\text { não creias }\end{array}$ & $\begin{array}{l}\text { Mas não suponhas, } \\
\text { não creias }\end{array}$ \\
\hline $\begin{array}{l}\text { Que o teu rigor me } \\
\text { consome, }\end{array}$ & $\begin{array}{l}\text { Que em teus olhos eu } \\
\text { lia, }\end{array}$ & $\begin{array}{l}\text { Que este rigor me } \\
\text { consome, }\end{array}$ & $\begin{array}{l}\text { Que o teu rigor me } \\
\text { consome, }\end{array}$ \\
\hline $\begin{array}{l}\text { Pois mesmo pobre } \\
\text { e sem nome, }\end{array}$ & $\begin{array}{l}\text { Não eram mais que } \\
\text { ironia, }\end{array}$ & $\begin{array}{l}\text { Pois mesmo pobre e } \\
\text { sem nome, }\end{array}$ & $\begin{array}{l}\text { Pois mesmo pobre e } \\
\text { sem nome, }\end{array}$ \\
\hline $\begin{array}{l}\text { Sei desprezar-te } \\
\text { também. }\end{array}$ & $\begin{array}{l}\text { Não eram mais que } \\
\text { irrisão. }\end{array}$ & $\begin{array}{l}\text { Sei desprezar-te } \\
\text { também. }\end{array}$ & $\begin{array}{l}\text { Sei desprezar-te } \\
\text { também. }\end{array}$ \\
\hline $\begin{array}{l}\text { Bem sei, mulher, } \\
\text { bem conheço } \\
\text { Que fui um louco }\end{array}$ & $\begin{array}{l}\text { Bem sei que tu me } \\
\text { desprezas, } \\
\text { Bem sei que tu me }\end{array}$ & $\begin{array}{l}\text { Bem sei, mulher, } \\
\text { bem conheço } \\
\text { Que fui um louco em }\end{array}$ & $\begin{array}{l}\text { Bem sei, mulher, } \\
\text { bem conheço } \\
\text { Que fui um louco em }\end{array}$ \\
\hline
\end{tabular}




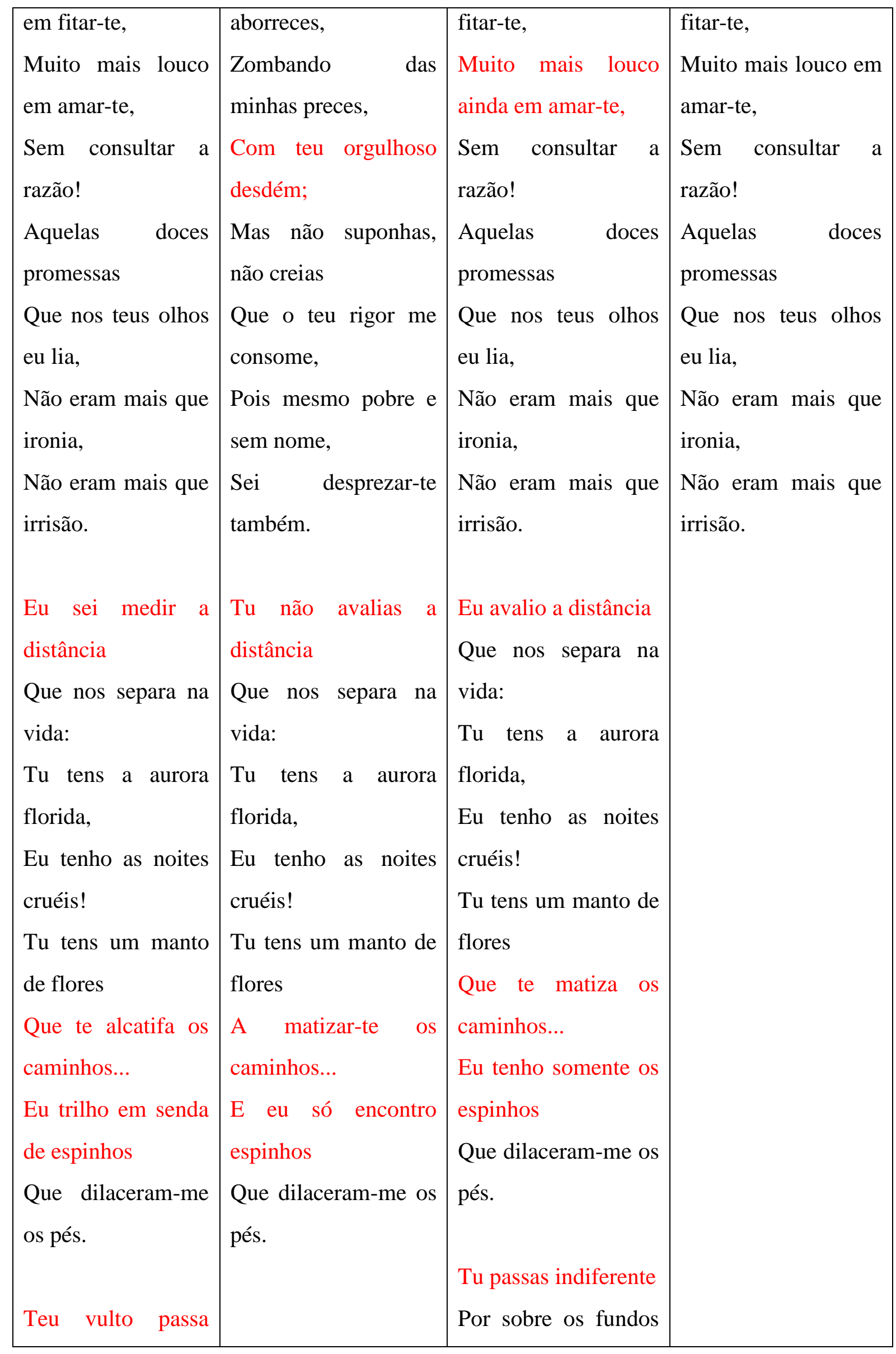




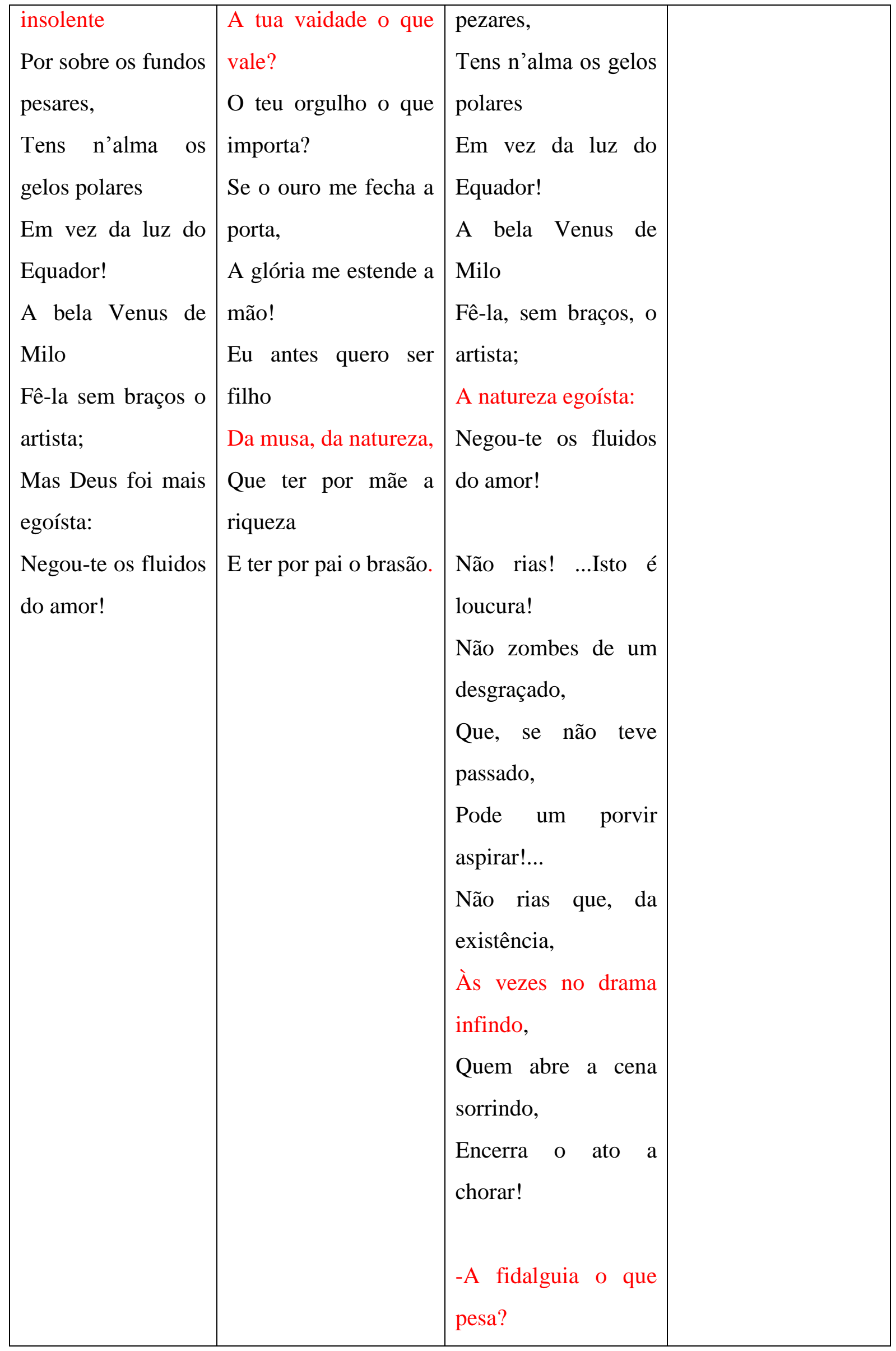




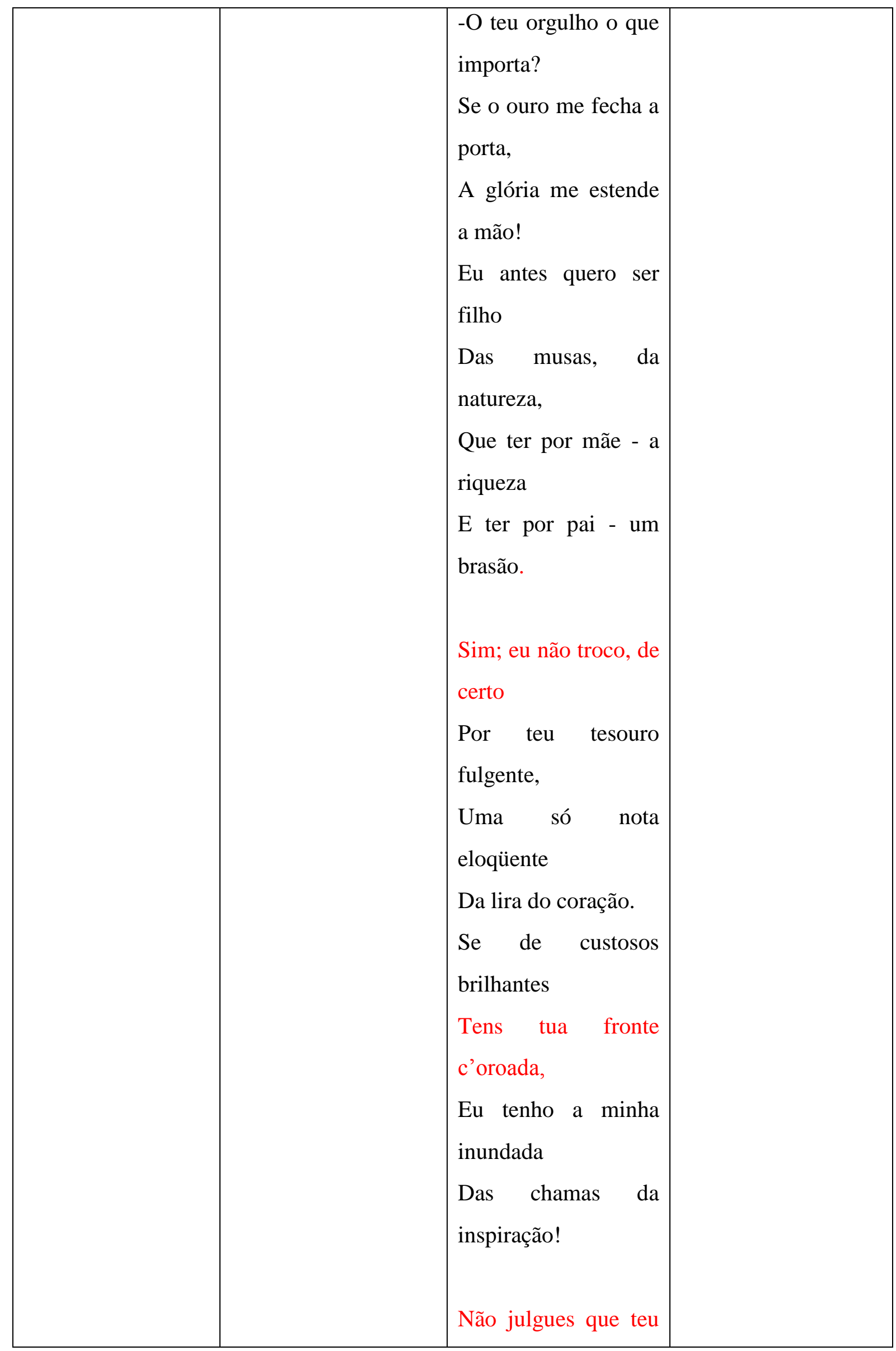




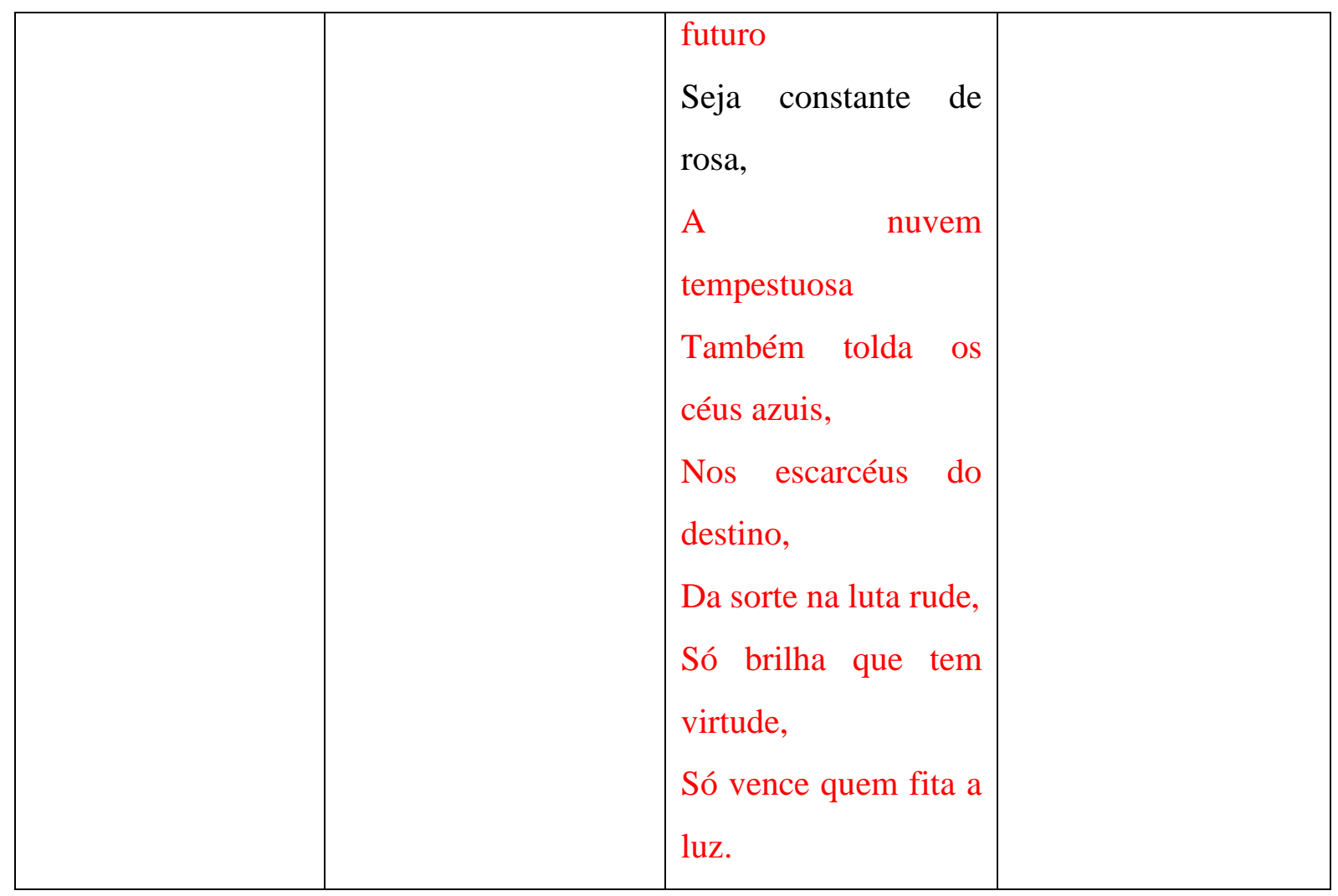

As 3 primeiras fontes que são Cancioneiro Popular de modinhas brasileiras, Serenatas e Saraús III e Canções Populares do Brazil possuem 8 estrofes e texto semelhante. Coligindo as três observamos pouquíssimas variações como na frase com teu orgulho e desdem ou com teu orgulhoso desdem ou ainda com orgulhoso desdem, que apresentam o mesmo sentido com pequena alteração na escrita do texto.

A quarta fonte que é da coletânea As mais belas modinhas apresenta um tamanho menor contando com apenas 4 estrofes. O texto é semelhante às três primeiras fontes com alteração apenas da frase Teu vulto passa indolente para Teu vulto passa insolente.

A quinta fonte é Modinhas Antigas e também apresenta um tamanho menor contando com apenas 4 estrofes. Observamos a troca na ordem da primeira com a segunda estrofe. Apresenta algumas variações nas estrofes seguintes. Abaixo coligimos o texto da primeira s fonte e o texto apresentado na coletânea em questão.

Eu sei medir a distancia - Tu não avalias a distância que te alcatifa os caminhos... - A matizar-te os caminhos...

Eu trilho em senda de espinhos - E eu só encontro espinhos 
A fidalguia o que vale? - A tua vaidade o que vale?

A sexta fonte é A modinha Norte-rio-grandense e conta com 8 estrofes. Esse registro é o que apresentou maior variação. Abaixo coligimos o texto da primeira fonte com a sexta.

zombando das minhas preces - Que zombas das minhas preces,

com teu orgulho e desdém - Com ostensivo desdém:

que o teu rigor me consome - Que este rigor me consome,

muito mais louco em amar-te - Muito mais louco ainda em amar-te,

Eu sei medir a distancia - Eu avalio a distância

que te alcatifa os caminhos... - Que te matiza os caminhos...

Eu trilho em senda de espinhos - Eu tenho somente os espinhos

Teu vulto passa indolente - Tu passas indiferente

mas Deus foi mais egoísta:- A natureza egoísta:

No drama, ignoto, infindo, - Às vezes no drama infindo,

A fidalguia o que vale? - -A fidalguia o que pesa?

A sétima estrofe tem uma troca na ordem, os quatro primeiros versos foram trocados pelos quatro últimos.

tu tens a fronte adornada,- Tens tua fronte c'oroada,

das ondas de inspiração! - Das chamas da inspiração!

Sim, eu não troco, orgulhoso, - Sim; eu não troco, de certo

uma só nota plangente - Uma só nota eloqüente

A última estrofe tem texto muito diferente daquele que foi apresentado nas outras fontes.

Não julgues que céo que sonhas, - Não julgues que teu futuro

seja constante de rosas, - Seja constante de rosa,

ha muitas sombras nublosas - A nuvem tempestuosa

para empannar-lhe o setim! - Também tolda os céus azuis, 
Nem sempre o lago é tranquillo, - Nos escarcéus do destino,

nem sempre a flor tem perfume, - Da sorte na luta rude,

nem sempre os astros têm lume... - Só brilha que tem virtude,

nem sempre o goso é sem fim... - Só vence quem fita a luz.

A sétima fonte $A$ modinha no grão-pará possui apenas duas estrofes. O texto é igual ao da coletânea Canções Populares do Brazil.

Abaixo seguem as partituras presentes nas D,E,F e G. 
Figura 21- Partitura da modinha O poeta e a Fidalga da fonte C

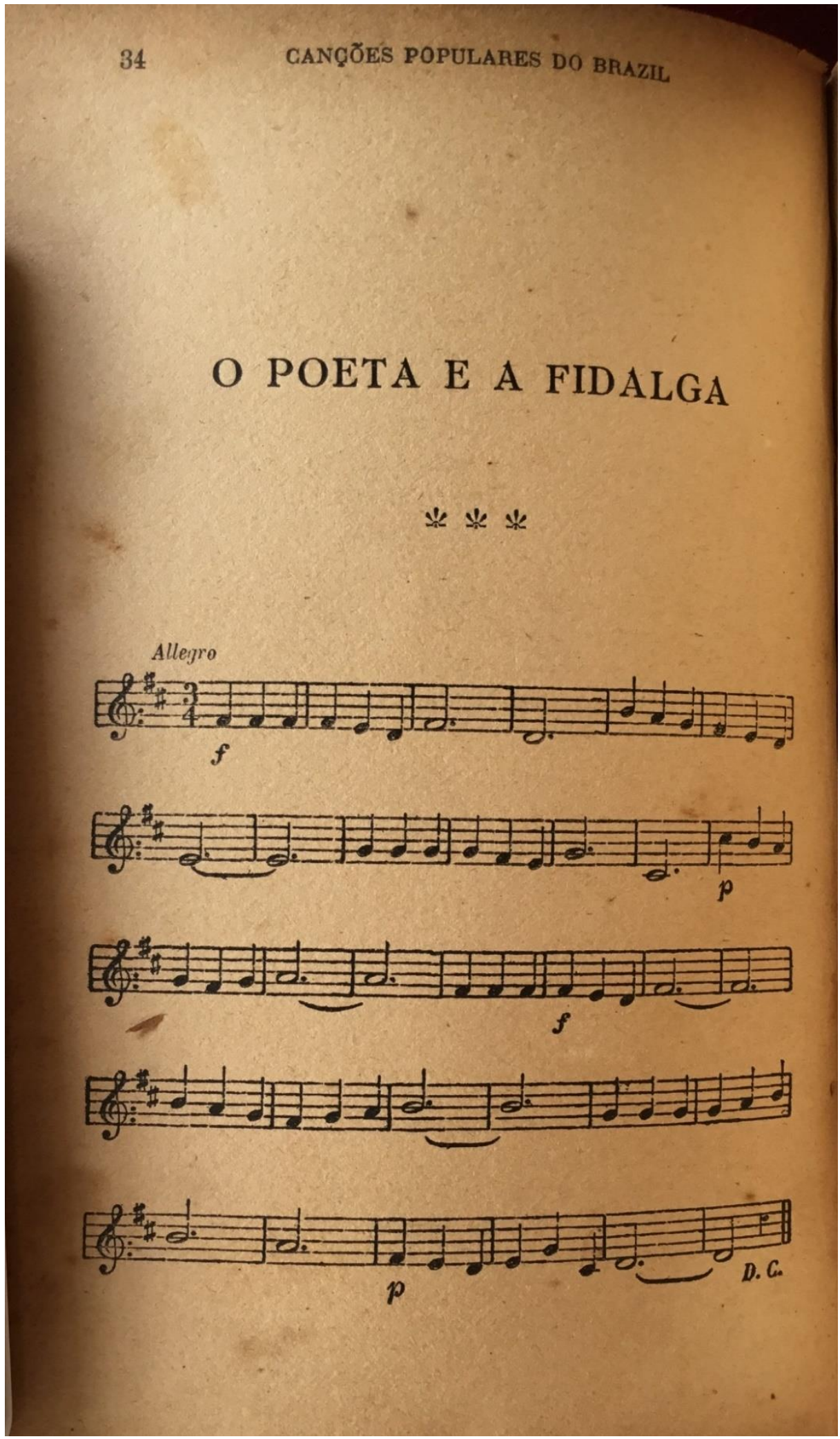

Fonte: Canções populares do Brazil 
Figura 22- Letra da modinha O poeta e a Fidalga da fonte C

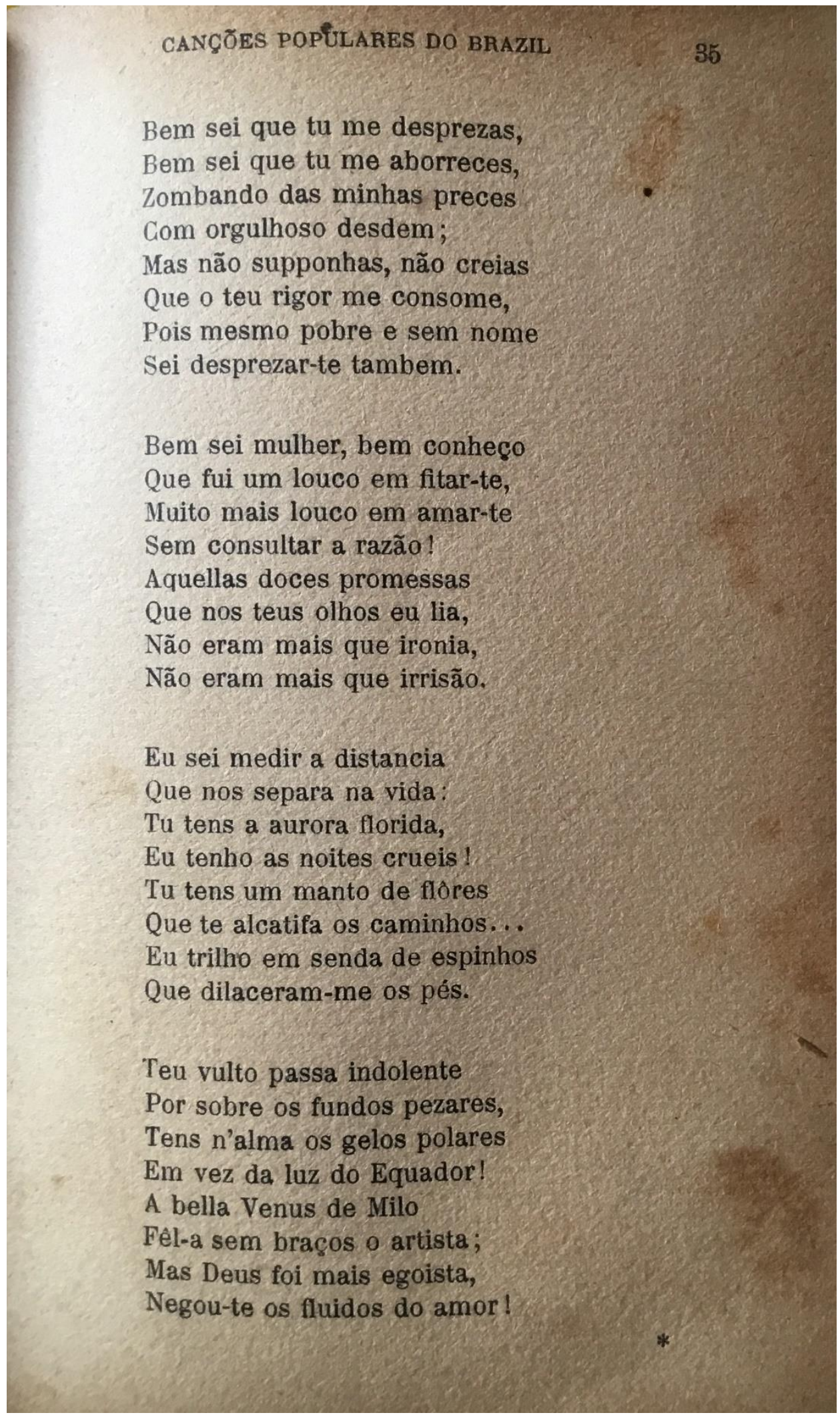

Fonte: Canções populares do Brazil 
Figura 23- Letra da modinha O poeta e a Fidalga da fonte C

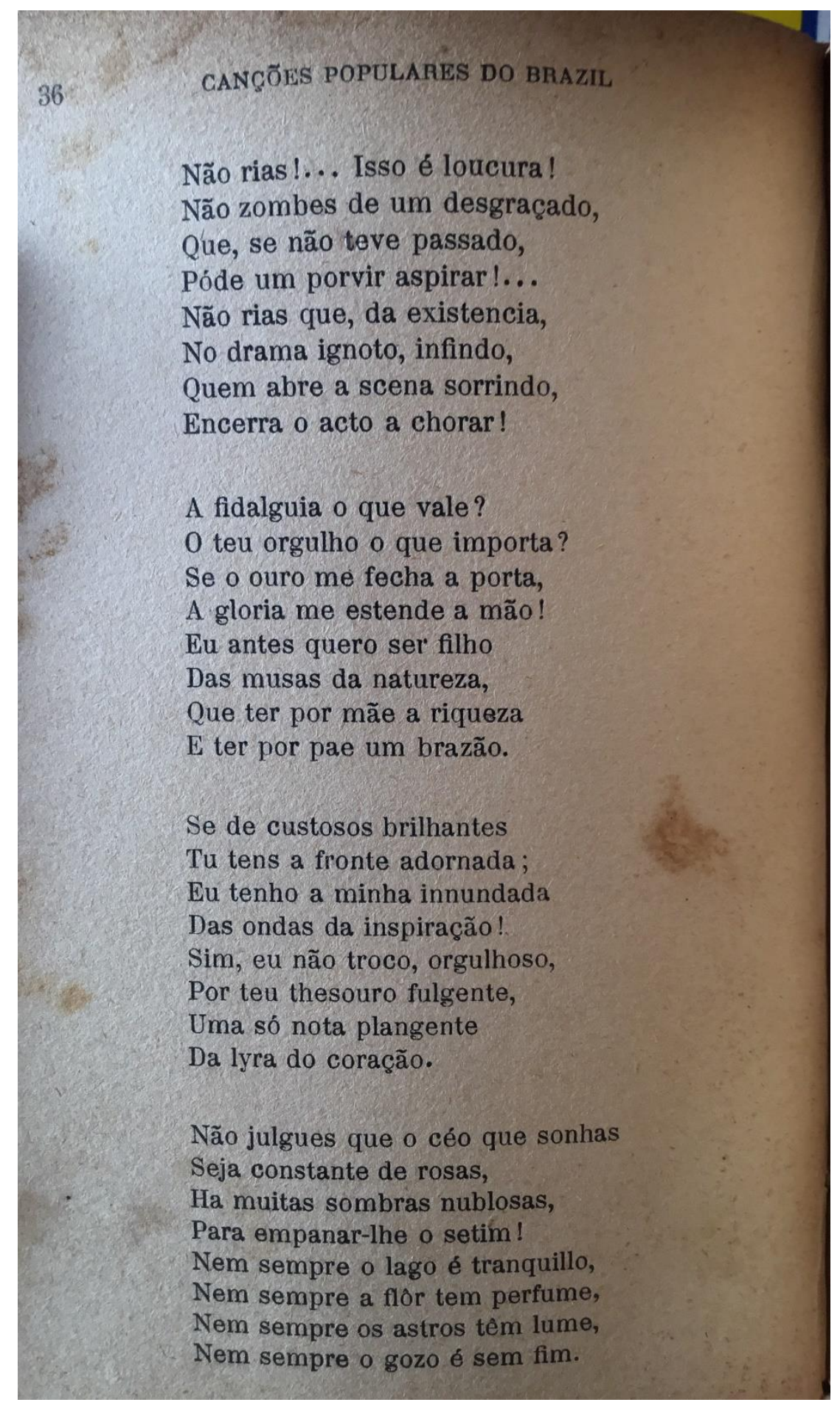

Fonte: Canções populares do Brazil 
Figura 24- Partitura da modinha O poeta e a Fidalga da fonte D

\section{Poeta e a Fidalga}

Bem sei que tu me desprezas, Bem sei que tu me aborreces, Zombando das minhas preces Com orgulhoso desdém Mas não suponhas, não Creias Que o teu rigor me consome, Pois mesmo pobre e sem nome Sei desprezar-te também.

Bem sei mulher, bem conheģo Que fui um louco em fitar-te Muito mais louco em amar-te Sem consultar a razão! Aquelas doces promessas Que nos teus-olhos eu lia, Não eram mais que ironia. Não eram mais que irrisão
Letra de Segundo Wanderley Música de Heronides França
Eu sei medir a distância Que nos separa na vida Tu tens a aurora florida, Eu tenho as nóites cruéis! $\mathrm{Tu}$ tens um manto de flores Que te alcatifa os caminhos... Eu trilho em senda de espinhos Que dilaceram-me os pés.

Teu vulto passa insolente Por sobre os fundos pesares, Tens n'alma os gelos polares Em vez da luz do Equador! A bela Vênus de Milo Fê-la sem braços o artista, Mas Deus foi mais egoista, Negou-te os flúidos do amor!
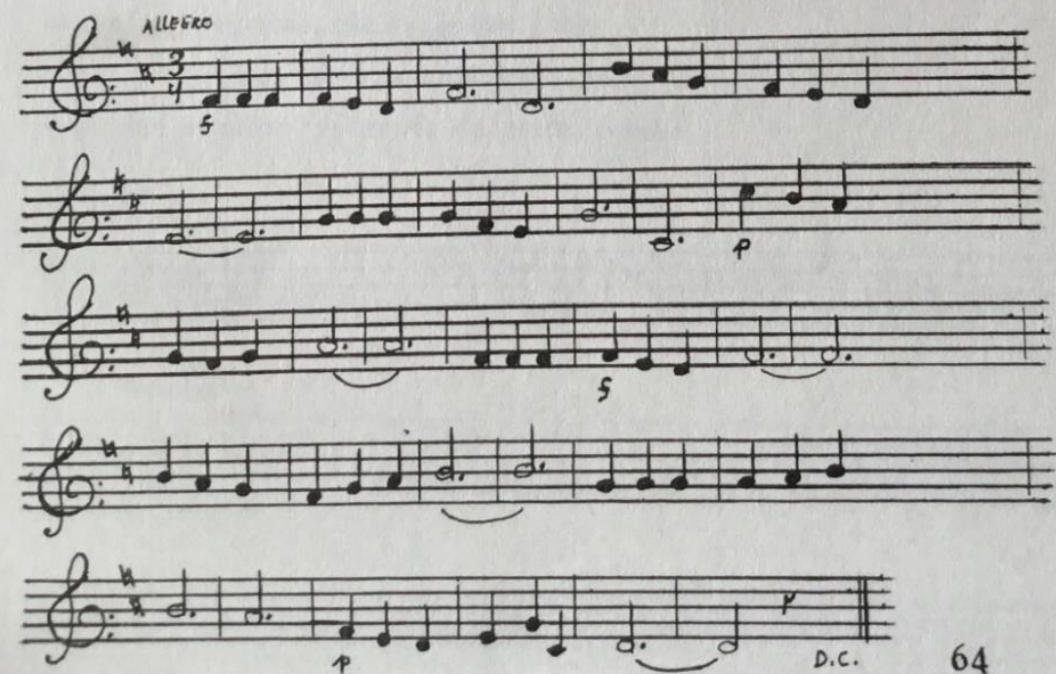

Fonte: As Mais belas modinhas 


\section{O POETA E A FIDALGA $\quad(5,8,16$ e 18)}

\section{Letra de Segundo Wanderley}

Música de Heronides França

Bem sei mulher, bem conheço Que fui um louco em fitar-te. Mais louco fui em amar-te Sem consultar à razão. Aquelas doces promessas, Que em teus olhos eu lia, Não eram mais que ironia, Não eram mais que ilusão.

Bem sei que tu me desprezas, Bem sei que tu te aborreces, Zombando de minhas preces, Com o teu orgulhoso desdém. Mas não suponhas, não creias Que o teu rigor me consome. Pois, mesmo pobre e sem nome, Sei desprezar-te também.

Tu não avalias a distância Que nos separa na vida: Tu tens a aurora florida E eu tenho as noites cruéis; Tu tens um manto de flores A matizar-te os caminhos. E eu, só encontro espinhos Que dilaceram-me os pés.

A tua vaidade o que vale? O teu orgulho o que importa? Se o ouro me fecha a porta, A glória me estende a mão. Eu antes quero ser filho Da musa, da natureza, Que ter por mãe a riqueza, Que ter por pai o brasão. 
Figura 26- Partitura da modinha O poeta e a Fidalga da fonte E

O POETA E A FIDALGA

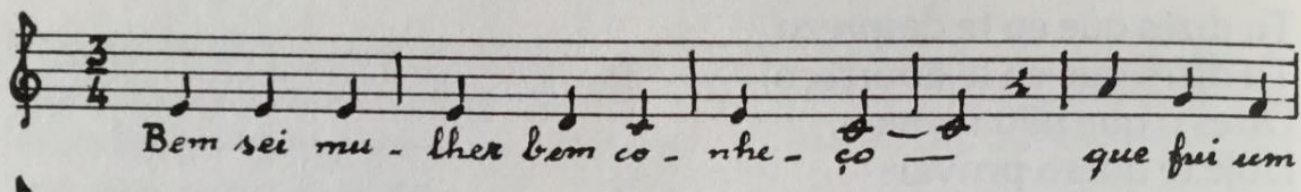

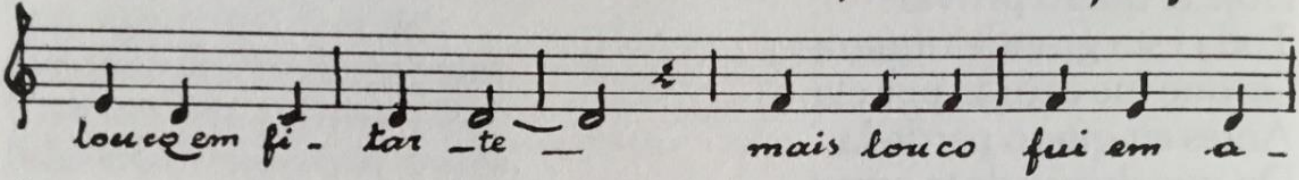
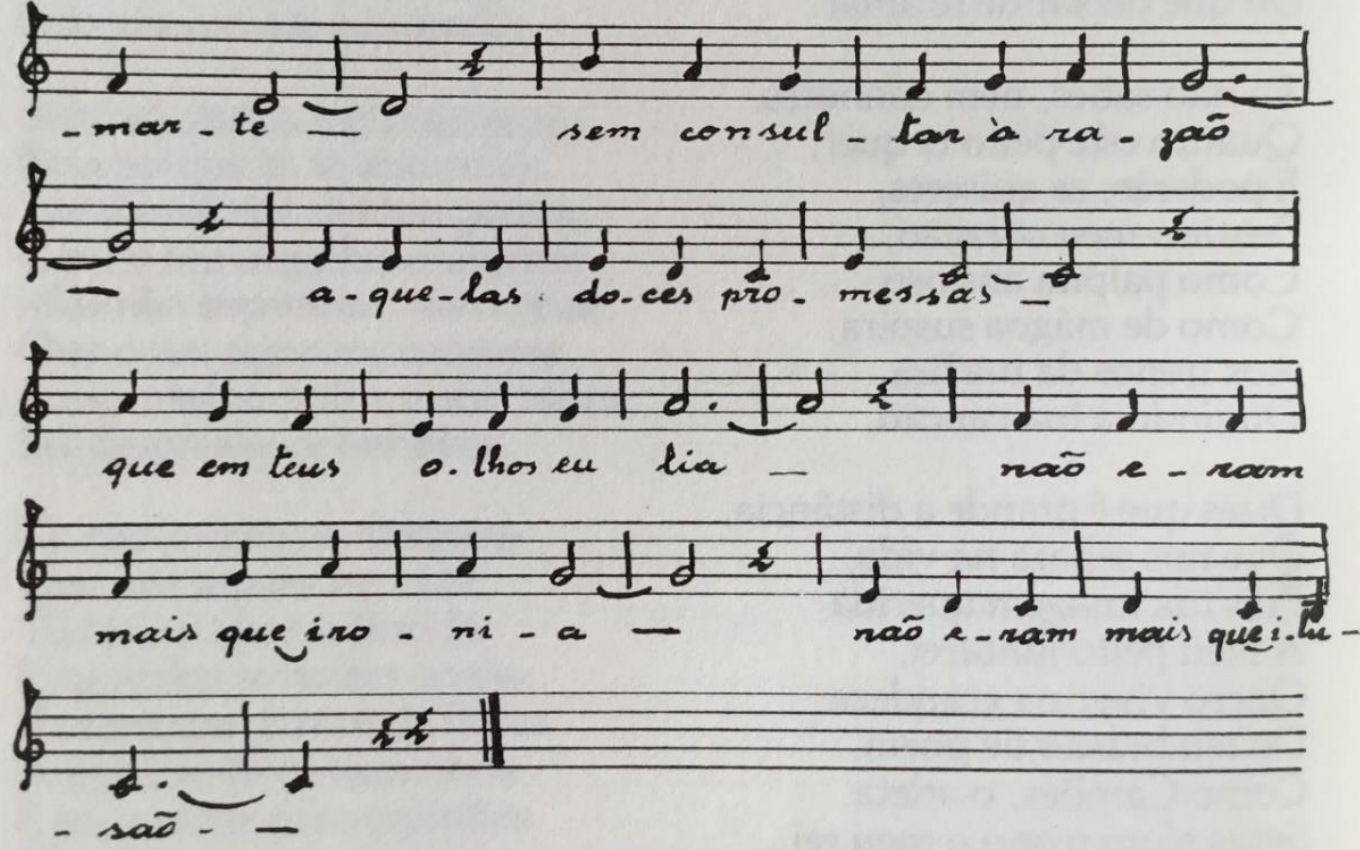

Fonte: Modinhas Antigas 
Figura 27- Partitura da modinha O poeta e a Fidalga da fonte F

$\begin{array}{lllllllllllllll}\text { O } & \text { P } & O & \text { E } & \text { T } & \text { A } & \text { E } & \text { A } & \text { F } & \text { I } & \text { D } & \text { A } & L & G & \text { A }\end{array}$

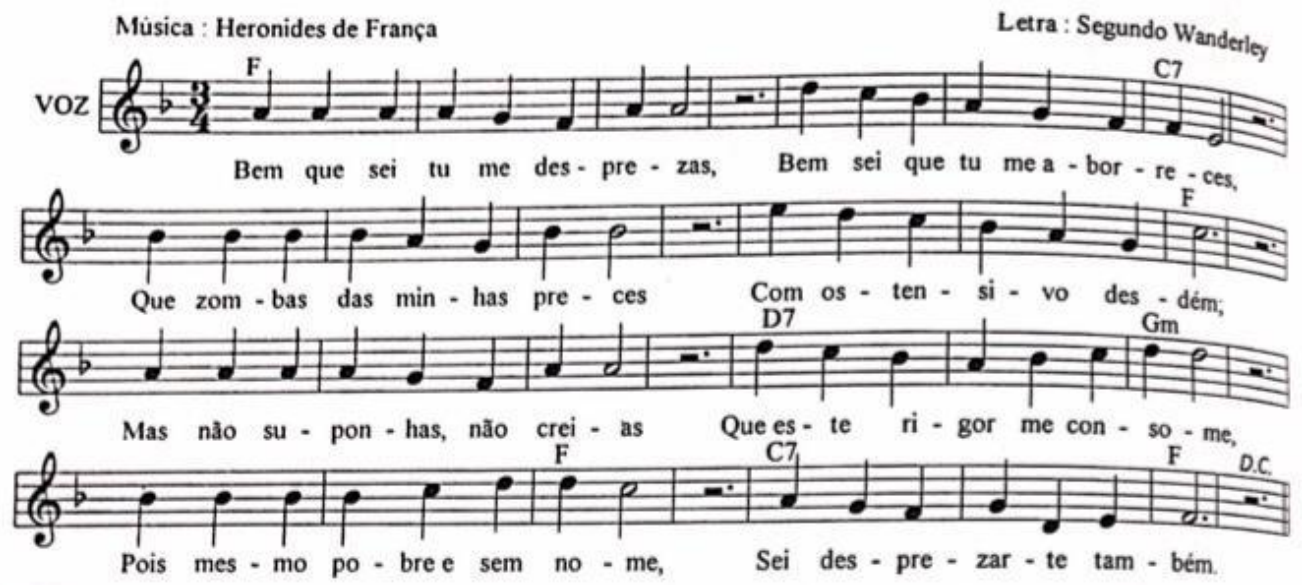

Bem sei, mulher, bem conheço,

Que fui um louco em fitar-te,

Mais louco ainda em amar-te

Sem consultar a razão!

Aquelas doces promessas

Que nos teus olhos eu lia

Não eram mais que ironia,

Não eram mais que irrisão

Eu avalio a distância

Que nos separa na vida,

Tu tens a aurora florida,

Eu tenho as noites cruéis;

Tu tens um manto de flores,

Que te matiza os caminhos,

Eu tenho somente espinhos

Que dilaceram-me os pés.

Tu passas indiferente Por sobre os fundos pesares,

Tens n'alma os gelos polares

Em vez da luz do equador;

A bela Vênus de Milo,

Fê-la, sem braços, o artista,

A natureza egoista

Negou-te os fluidos do amor.
Não rias... isto é loucura! Não zombes do desgrafado Que se não teve um passado Pode um porvir aspirar; Não rias... que da existência, Às vezes, no drama infindo, Quem abre a cena, sorrindo, Encerra o ato a chorar.

- A fidalguia o que pesa? - O teu orgulho o que importa? Se o ouro me fecha a porta, A glória me estende a mão; Eu quero antes ser filho Das musas, da natureza, Que ter por mãe a - riqueza, Que ter por pai - um brasão.

Sim; eu não troco, de certo, Por teu tesouro fulgente Uma só nota eloquuente Da lira do coração; Se de custosos brilhantes Tens tua fronte $c^{\prime}$ roada, Eu tenho a minha inundada Das chamas da inspiração.
Não julgues que teu futuro Seja constarte de rosa, A nuvem tempestuosa Também tolda os céus azuis, Nos escarcéus do destino, Da sorte na luta rude, Só brilha quem tem virtude, Só vence quem fita a luz.

\section{FONTE}

Música : Consuelo Wanderley Letra : "Recoltas Poéticas", 1896

Obs.: Publicada em:

1 - "Cançōes Populares do Brasil": letra com pequenas diferenças $e$ música igual. Não indica os autores 2- "As mais belas modinhas", vol. I, com versos incompletos e música igual No mesmo volume, com 0 título de "Bem sei mulher, bem co $^{\text {. }}$ nheço".

3 - "Modinhas Antigas", com ver sos incompletos e música igual à presente. 
Figura 28- Partitura da modinha O poeta e a Fidalga da fonte G

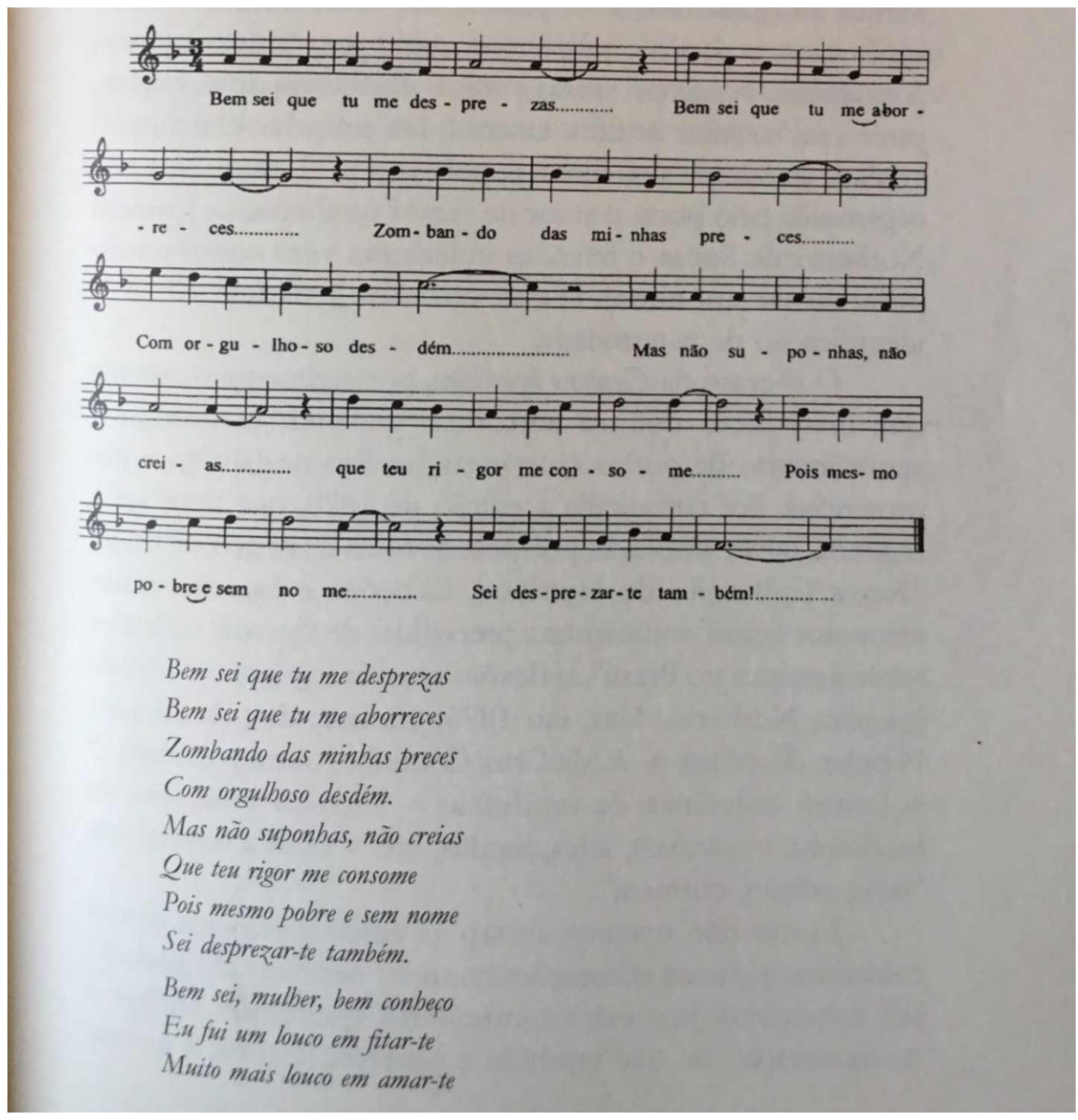

Fonte: A modinha no Grão-Pará 
Figura 29- Letra da modinha O poeta e a Fidalga da fonte G

\section{2}

Sem consultar a raz̃ão.

Aquelas doces promessas

Que nos teus olhos eu lia

Não eram mais que ironia

Não eram mais que irrisão.

Fonte: A modinha no Grão-Pará

Comparando as cinco fontes com registros em partitura, listamos: nas colunas as fontes, e nas linhas o contorno melódico de cada registro. Desconsiderando a duração das notas e observando apenas o contorno melódico, assinalamos, abaixo, a presença de alterações, mantendo, com as mesmas cores, os contornos semelhantes.

Tabela 22- Contorno melódico de $O$ poeta e a Fidalga dos compassos 1 ao 4

\begin{tabular}{|l|l|}
\hline & \\
\hline C & 33332131 \\
\hline D & 33332131 \\
\hline E & 33332131 \\
\hline F & 33332133 \\
\hline G & 333321333 \\
\hline
\end{tabular}

Tabela 23- Contorno melódico de $O$ poeta e a Fidalga dos compassos 5 ao 8

\begin{tabular}{|l|l|}
\hline & \\
\hline C & 65432122 \\
\hline D & 65432122 \\
\hline E & 65432122 \\
\hline F & $6543211 \underline{7}$ \\
\hline G & 654321222 \\
\hline
\end{tabular}


Tabela 24-Contorno melódico de $O$ poeta e a Fidalga dos compassos 9 ao 12

\begin{tabular}{|l|l|}
\hline & \\
\hline C & $4444324 \underline{7}$ \\
\hline D & $4444324 \underline{7}$ \\
\hline E & 444432411 \\
\hline F & 44443244 \\
\hline G & 444432444 \\
\hline
\end{tabular}

Tabela 25- Contorno melódico de O poeta e a Fidalga dos compassos 13 ao 16

\begin{tabular}{|l|l|}
\hline & \\
\hline C & 76543455 \\
\hline D & 76543455 \\
\hline E & 76545655 \\
\hline F & 7654325 \\
\hline G & 76543455 \\
\hline
\end{tabular}

Tabela 26- Contorno melódico de O poeta e a Fidalga dos compassos 17 ao 20

\begin{tabular}{|l|l|}
\hline & \\
\hline C & 33332133 \\
\hline D & 33332133 \\
\hline E & 333321311 \\
\hline F & 33332133 \\
\hline G & 333321333 \\
\hline
\end{tabular}

Tabela 27- Contorno melódico de O poeta e a Fidalga dos compassos 21 ao 24

\begin{tabular}{|l|l|}
\hline & \\
\hline C & 65434566 \\
\hline D & 65434566 \\
\hline E & 65434566 \\
\hline
\end{tabular}




\begin{tabular}{|l|l|}
\hline F & 65434566 \\
\hline G & 654345666 \\
\hline
\end{tabular}

Tabela 28- Contorno melódico de O poeta e a Fidalga dos compassos 25 ao 28

\begin{tabular}{|l|l|}
\hline & \\
\hline C & 44445665 \\
\hline D & 44445665 \\
\hline E & 444456655 \\
\hline F & 44445665 \\
\hline G & 444456655 \\
\hline
\end{tabular}

Tabela 29- Contorno melódico de O poeta e a Fidalga dos compassos29 ao 32.

\begin{tabular}{|l|l|}
\hline & \\
\hline C & $32124 \underline{7} 11$ \\
\hline D & $32124 \underline{\underline{z} 11}$ \\
\hline E & $32121 \underline{7} 11$ \\
\hline F & $3212 \underline{\mathbf{6}} \underline{1}$ \\
\hline G & $32124 \mathbf{3 1 1}$ \\
\hline
\end{tabular}

Observamos que, as variações melódicas, em geral, acontecem nas cadências ou em momentos de preparação da cadência. Não observamos variações no início das frases.

3.3 Questões interpretativas relacionadas à vocalidade na circulação do salão para a seresta.

A modinha Róseas flores d'alvorada está presente em 5 fontes. As fontes estão descritas abaixo. Essa modinha tem, tanto poeta, quanto compositor desconhecidos. 
Tabela 30- Informações da modinha considerada de salão Róseas flores d'alvorada

\begin{tabular}{|l|l|l|l|l|}
\hline $\begin{array}{l}\text { Título } \\
\text { Róseas flores } \\
\text { d'alvorada }\end{array}$ & $\begin{array}{l}\text { Róseas flores } \\
\text { d'alvorada }\end{array}$ & Desconhecido & Desconhecido & Modinhas do Passado \\
\hline $\begin{array}{l}\text { Róseas flores } \\
\text { d'alvorada }\end{array}$ & $\begin{array}{l}\text { Róseas flores } \\
\text { d'alvorada }\end{array}$ & Desconhecido & Desconhecido & $\begin{array}{l}\text { As mais belas } \\
\text { modinhas Vol. II }\end{array}$ \\
\hline $\begin{array}{l}\text { Roseas flores } \\
\text { d'alvorada }\end{array}$ & $\begin{array}{l}\text { Roseas flores } \\
\text { d'alvorada }\end{array}$ & Desconhecido & Desconhecido Trovador \\
\hline $\begin{array}{l}\text { Roseas flores } \\
\text { d'alvorada }\end{array}$ & $\begin{array}{l}\text { Roseas flores } \\
\text { d'alvorada }\end{array}$ & Desconhecido & Desconhecido & Modinhas imperiais \\
\hline $\begin{array}{l}\text { Róseas flores } \\
\text { d'alvorada }\end{array}$ & $\begin{array}{l}\text { Roseas flores } \\
\text { d'alvorada }\end{array}$ & Desconhecido & Desconhecido modinhas brazileiras \\
\hline
\end{tabular}

Fonte: Lista de modinhas

Abaixo listamos as fontes localizadas por ordem da primeira publicação e, em seguida, comparamos as letras das cinco fontes.

Tabela 31- Ordem cronológica das fontes da modinha Róseas flores d'alvorada

\begin{tabular}{|l|l|l|}
\hline & FONTE & $\begin{array}{l}\text { ANO DA PRIMEIRA } \\
\text { PUBLICAÇÂO }\end{array}$ \\
\hline A & $\begin{array}{l}\text { Trovador - Colecção de modinhas, lundus, árias , } \\
\text { recitativos e etc. }\end{array}$ & 1876 \\
\hline B & Nova Collecção de modinhas brasileiras & 1878 \\
\hline C & Modinhas Imperiais & 1930 \\
\hline D & Modinhas do Passado & 1956 \\
\hline E & As mais belas modinhas Vol.II & 1982 \\
\hline
\end{tabular}

Fonte: Lista de coletâneas

As letras estão reproduzidas abaixo, com marcações em vermelho, das variações. 
Tabela 32- Letras da modinha Róseas flores d'alvorada nas fontes A,B e C

\begin{tabular}{|c|c|c|}
\hline A- Trovador & $\begin{array}{l}\text { B - Nova Collecção de } \\
\text { modinhas brasileiras }\end{array}$ & C- Modinhas Imperiais \\
\hline Roseas flores d'alvorada & Roseas flores d'alvorada & Roseas flores d'alvorada \\
\hline Róseas flores d'alvorada & Róseas flores d'alvorada & Roseas flores d'alvorada \\
\hline Teus perfumes causão & Teus perfumes causão dôr: & Teus perfumes causam dôr... \\
\hline dôr: & Essa imagem que recordas & Roseas flores d'alvorada \\
\hline $\begin{array}{l}\text { Essa imagem que recordas } \\
\text { É meu puro e santo amor. }\end{array}$ & É meu puro e santo amor. & $\begin{array}{l}\text { Teus perfumes causam dôr, } \\
\text { Essa imagem que recordas }\end{array}$ \\
\hline & Ai quem respira & É meu puro e santo amor \\
\hline Ai! quem respira & Os teus odores; & Essa imagem que recordas \\
\hline Os teus odores; & Fenece triste, & É meu puro e santo amor \\
\hline Fenece triste, & Morre de amores. & \\
\hline Morre de amores. & Não póde gozar venturas & $\begin{array}{l}\text { Ai! Quem respira } \\
\text { Os teus odôres, }\end{array}$ \\
\hline $\begin{array}{l}\text { Não póde gozar venturas } \\
\text { Quem de amores soffre } \\
\text { affliçção, }\end{array}$ & $\begin{array}{l}\text { Quem de amores sofre } \\
\text { affliçcção, } \\
\text { Não póde, afeito aos gemidos }\end{array}$ & $\begin{array}{l}\text { Fenece triste, } \\
\text { Morre de amores. }\end{array}$ \\
\hline $\begin{array}{l}\text { Não póde, afeito aos } \\
\text { gemidos }\end{array}$ & Ter prazer no coração. & $\begin{array}{l}\text { Não pôde gosar venturas } \\
\text { Quie de amor sofre aflição }\end{array}$ \\
\hline Ter prazer meu coração. & Ai quem, etc. & $\begin{array}{l}\text { Não póde afeito aos gemidos } \\
\text { Ter prazer meu coração. }\end{array}$ \\
\hline Ai! quem respira etc. & $\begin{array}{l}\text { Sem os sonhos de ventura } \\
\text { Murchou-se a flor do desejo; }\end{array}$ & Ai! Quem respira, etc. \\
\hline Sem os sonhos de ventura & Que m’importão outras flores & \\
\hline $\begin{array}{l}\text { Murchou-se a flôr do } \\
\text { desejo; }\end{array}$ & Se a minha flôr eu não vejo. & $\begin{array}{l}\text { Sem os sonhos de ventura } \\
\text { Murchou-se a flôr do desejo, }\end{array}$ \\
\hline $\begin{array}{l}\text { Que m'importam outras } \\
\text { flôres }\end{array}$ & Ai quem, etc. & $\begin{array}{l}\text { Que m'importam outras } \\
\text { flores }\end{array}$ \\
\hline $\begin{array}{l}\text { Se a minha bella eu não } \\
\text { vejo. }\end{array}$ & $\begin{array}{l}\text { Deixai que'eu viva de penas, } \\
\text { Da saudade e da lembrança; }\end{array}$ & Si a minha bela eu não vejo. \\
\hline
\end{tabular}




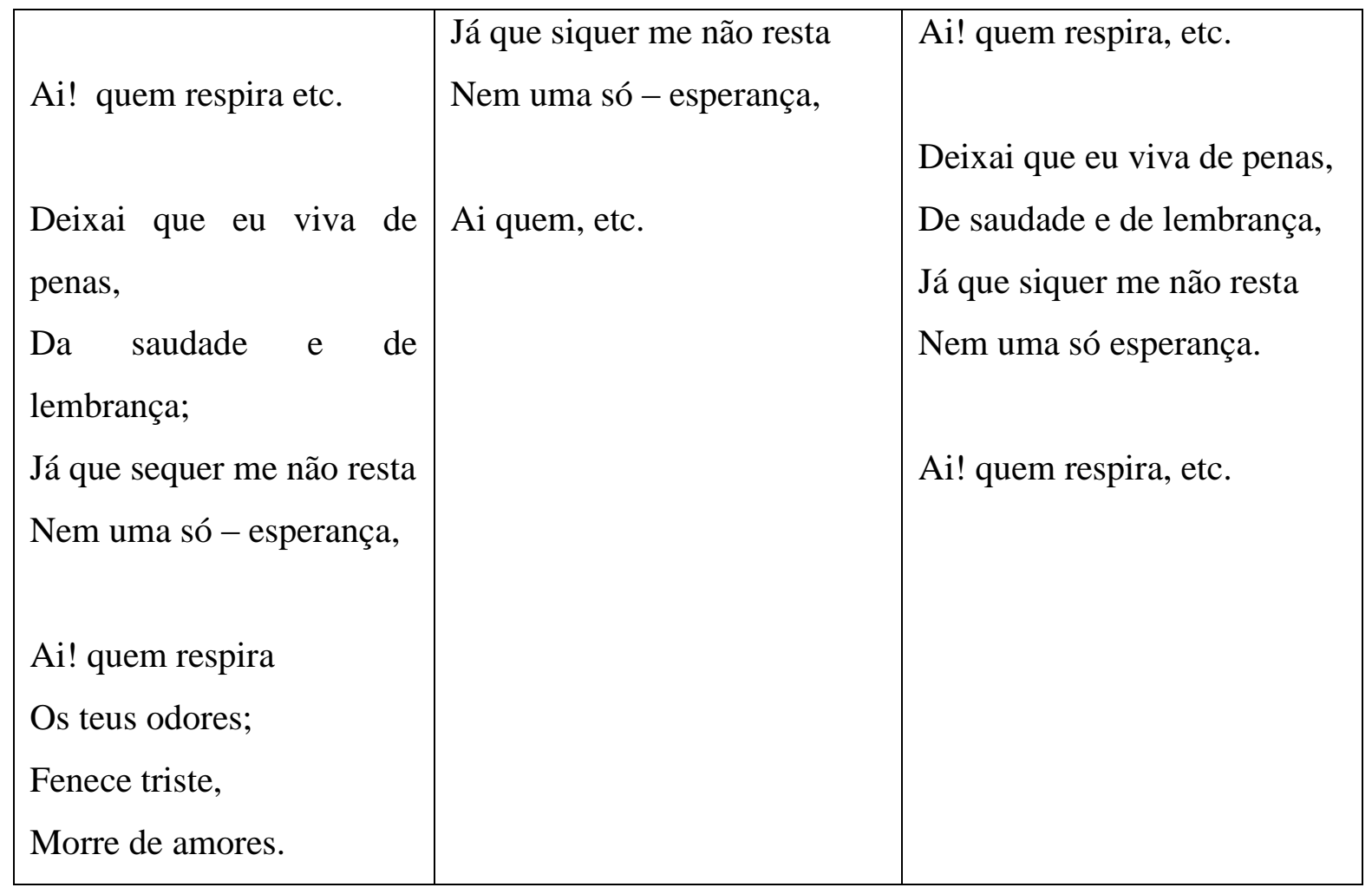

Fonte: Coletâneas A,B e C

Tabela 33- Tabela 32- Letras da modinha Róseas flores d'alvorada nas fontes D e E

\begin{tabular}{|l|l|}
\hline D - Modinhas do Passado & E - As mais belas modinhas Vol.II \\
\hline Róseas flores d'alvorada & Róseas flores d'alvorada \\
Roseas flores d'alvorada & Roseas flores d'alvorada \\
Teus perfumes causam dor & Teus perfumes causam dor... \\
Roseas flores d'alvorada & Essa imagem que recordas \\
Teus perfumes causam dor & É meu puro e santo amor. \\
Essa imagem que recordas & \\
É meu puro e santo amor & Coro \\
Essa imagem que recordas & Ai! Quem respira \\
É meu puro e santo amor & Os teus odores, \\
& Fenece triste \\
Ah! Quem respira os teus odores & Morre de amores. \\
Fenece triste & Não pode gosar venturas \\
\hline
\end{tabular}




\begin{tabular}{|c|c|}
\hline Morre de amores... & $\begin{array}{l}\text { Que de amor sofre aflição } \\
\text { Não pode afeito aos gemidos }\end{array}$ \\
\hline $\begin{array}{l}\text { Não pode gozar venturas } \\
\text { Quem de amor sofre aflição }\end{array}$ & Ter prazer meu coração. \\
\hline Não pode afeito aos gemidos & Sem os sonhos de ventura \\
\hline Ter prazer meu coração & $\begin{array}{l}\text { Murchou-se a flor do desejo, } \\
\text { Que m'importam outras flores }\end{array}$ \\
\hline $\begin{array}{l}\text { Deixai que eu viva de penas } \\
\text { De saudades e lembranças }\end{array}$ & Si a minha bela eu não vejo. \\
\hline Já que sequer não resta & Deixai que eu viva de penas, \\
\hline Nem uma só esperança & $\begin{array}{l}\text { De saudade e de lembrança, } \\
\text { Já que siquer me não resta } \\
\text { Nem uma só esperança. }\end{array}$ \\
\hline
\end{tabular}

Fonte: Coletâneas D e E

Além das atualizações da gramática, as letras são bem parecidas com poucas variações como as que ocorreram nos trechos:

Ter prazer meu coração / Ter prazer no coração

Se a minha flôr eu não vejo / Se a minha bela eu não vejo

Já que sequer me não resta / Já que sequer não resta.

Na coletânea C - Modinhas do Passado, foi omitida uma estrofe da letra.

Sem os sonhos de ventura

Murchou-se a flor do desejo,

Que m'importam outras flores

Si a minha bela eu não vejo.

As coletâneas A e B : Nova Collecção de modinhas brasileiras e Trovador, não possuem registro musical. A coletânea C - Modinhas Imperiais possui partitura para voz e piano e as demais contam com registro da melodia.

A modinha Roseas flores d'alvorada tem duas partes: estrofe (A) e refrão (C), sendo a 
primeira em compasso quaternário e o refrão em compasso ternário. Possui 24 compassos, sendo 16 na parte A e 8 na parte $\mathrm{C}$.

Abaixo inserimos as partituras presentes nas coletâneas Modinhas Imperiais, Modinhas do Passado e As mais belas modinhas II.

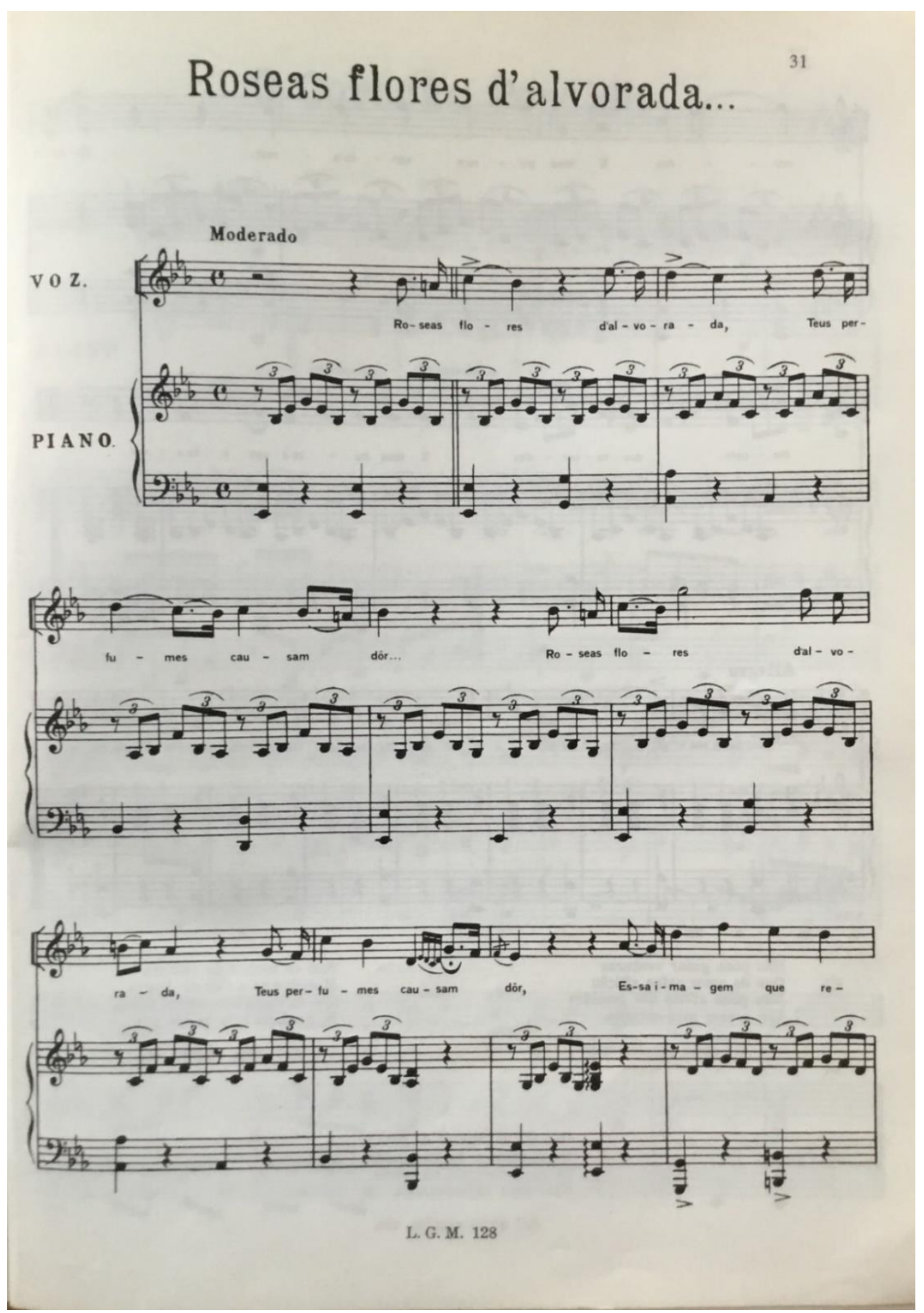

Fonte: Modinhas Imperiais 
Figura 31- Segunda página da partitura de Róseas flores d'alvorada da fonte C

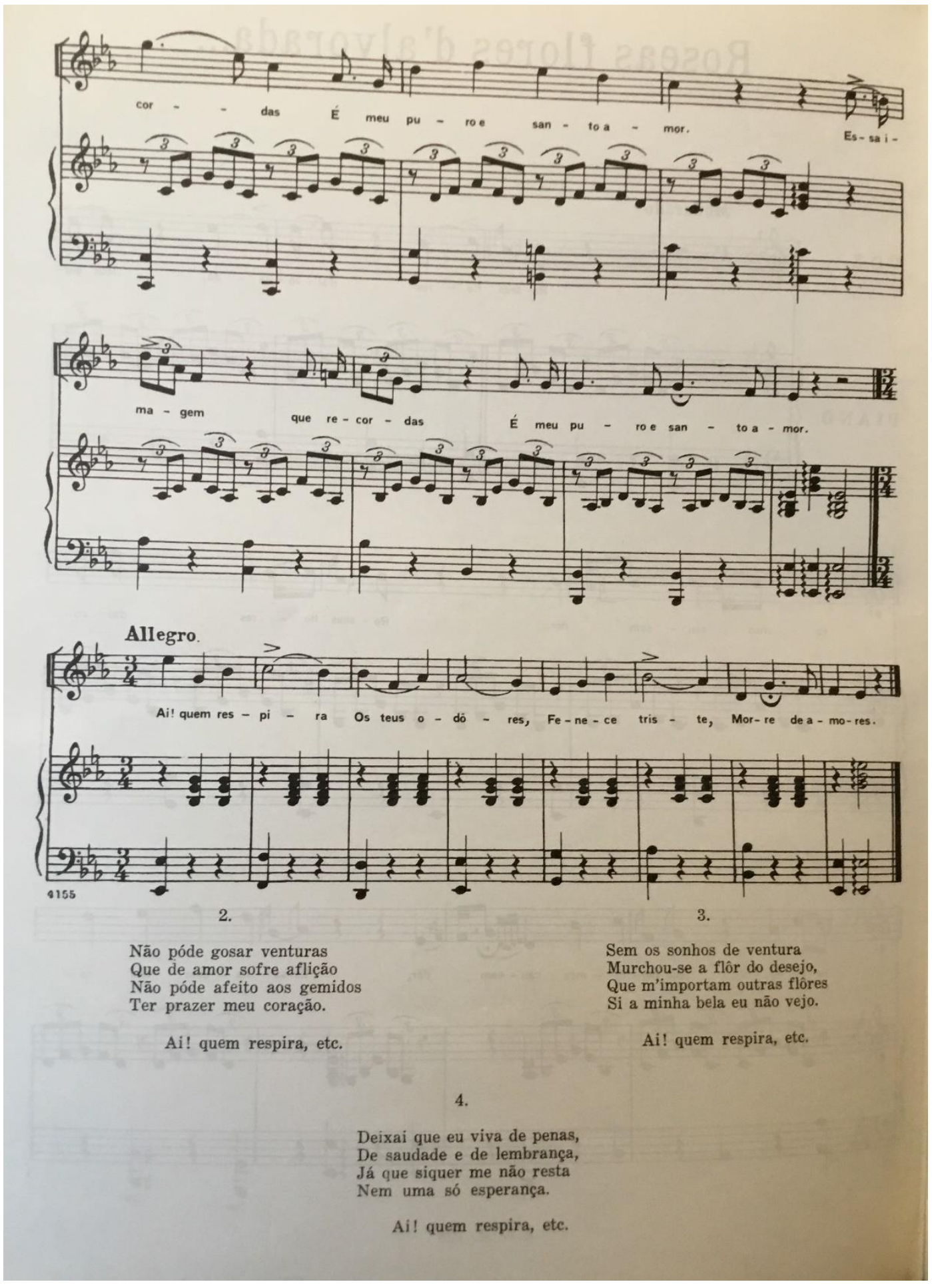

Fonte : Modinhas Imperiais 
Figura 32- Partitura da modinha Róseas flores d'alvorada da fonte D

\section{RÓSEAS FLORES D'ALVORADA *}

(Modinha imperial de caráter erudito)
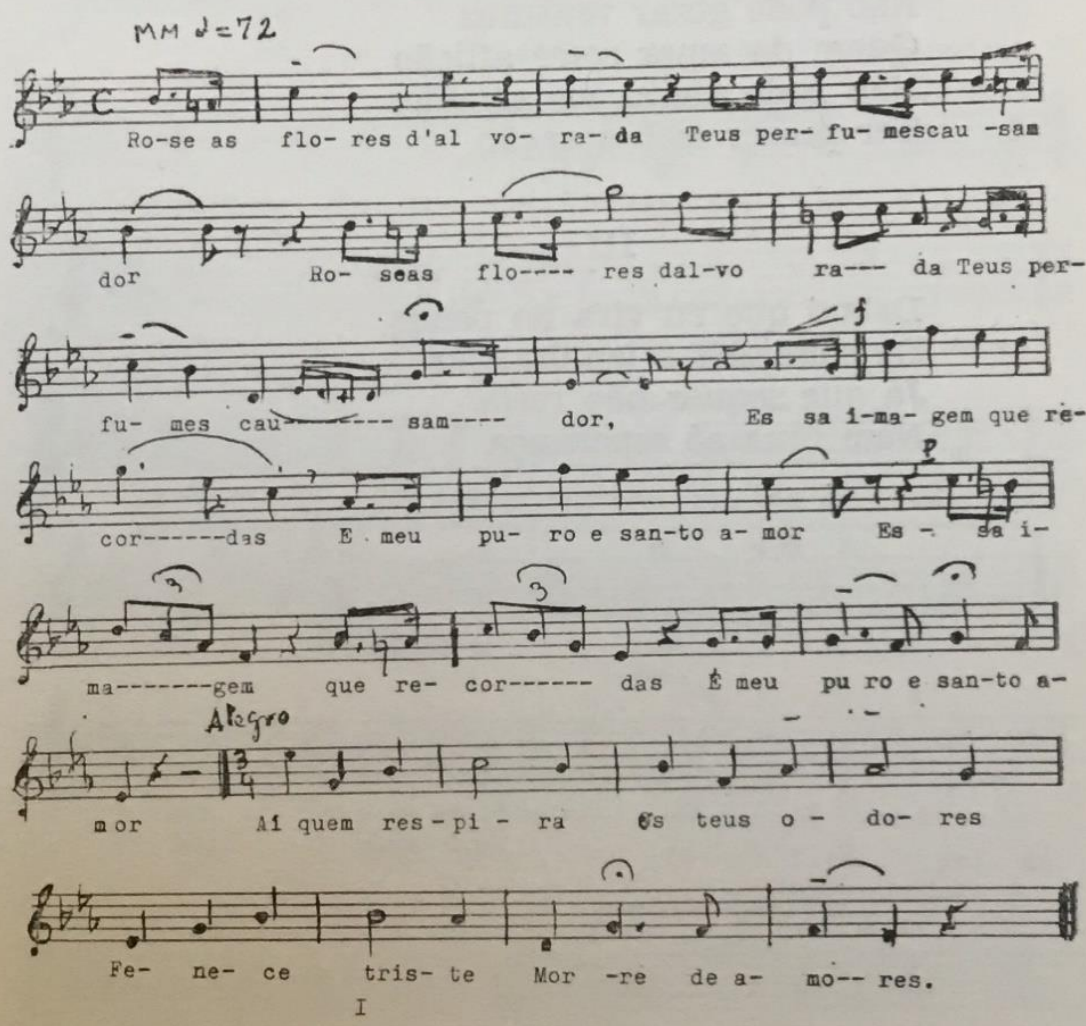

I

Róseas flores d'alvorada

Teus perfumes causam dor...

Essa iniagim que recordas

$\mathrm{E}$ meu puro e santo amor

- Foi publicada por Pierre Laforge e depois, reproduzida por Mário de Andrade, sem modificaçóes.

Aparece como popular e anônima em Trovador (1876), $1^{\circ}$ vol., pág. 96. 
Figura 33- Letra de Róseas flores d'alvorada da fonte D

Estribilho:

Ah! quem respira os teus odores Fenece triste Morre de amores...

II

Não pode gozar venturas

Quem de amor sofre aflição

Não pode afeito aos gemidos

Ter prazer meu coração

III

Deixai que eu viva de penas

De saudades e lembranças

Já que sequer não resta

Nem uma só esperança

Fonte : Modinhas do Passado 
Figura 34- Partitura de Róseas flores d'alvorada da fonte E

98

\section{RÓSEAS FLORES d'ALVORADA...}

Roseas flores d'alvorada

Teus perfumes causam dor...

Essa imagem que recordas

É meu puro e santo amor.

\section{Coro}

Ai! quem respira

Os teus odores,

Fenece triste,

Morre de amores.

Não pode gosar venturas

Que de amor sofre aflição

Não pode afeito aos gemidos

Ter prazer meu coração.

Sem os sonhos de ventura

Murchou-se a flor do desejo,

Que m'importam outras flores

Si a minha bela eu não vejo.

Deixai que eu viva de penas, De saudade e de lembrança,

Já que siquer me não resta

Nem uma só esperança.
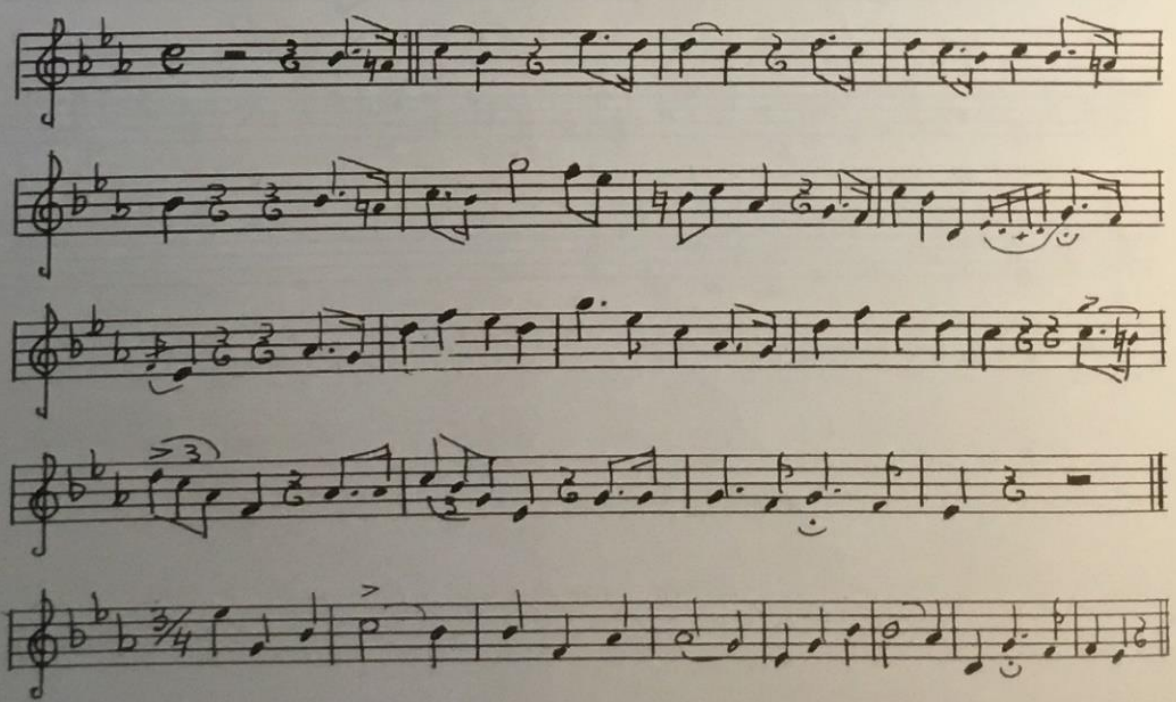

Fonte: As mais belas modinhas II

Segue abaixo o contorno melódico de cada uma das melodias. Como já explicitado 
utilizaremos os graus da escala para demonstrar.

Tabela 34- Contorno melódico de Róseas flores d'alvorada dos compassos 1 ao 8 ( $1^{\circ}$ tempo)

\begin{tabular}{|c|c|}
\hline $\mathrm{C}$ & $5 \sharp 4658776767656544554465109845643265 \underline{717673221}$ \\
\hline $\mathrm{D}$ & $5 \dashv 46587767676565 \dashv 4554465109845643265717 \underline{767321}$ \\
\hline $\mathrm{E}$ & $5 \curvearrowleft 46587767676565 \dashv 4554465109845643265717673221$ \\
\hline
\end{tabular}

Tabela 35-Contorno melódico de Róseas flores d'alvorada dos compassos 8 (final) ao 16

\begin{tabular}{|l|l|}
\hline C & 43798710864379876 6 557642 4Ł465313332321 \\
\hline D & 43798710864379876 6 45764254465313332321 \\
\hline E & 437987108643798766 657642 4465313332321 \\
\hline
\end{tabular}

Tabela 36- Contorno melódico de Róseas flores d'alvorada dos compassos 17 ao 24

\begin{tabular}{|l|l|}
\hline C & $835655244313554 \underline{7} 3221$ \\
\hline D & $835655244313554 \underline{7} 3221$ \\
\hline E & $835655244313554 \underline{7} 3221$ \\
\hline
\end{tabular}

A construção da linha melódica é quase igual, com uma variação, como assinalada acima em cor vermelha.

No segundo capítulo, observamos que, de todos os critérios elencados, a observação da construção da linha melódica seria o critério principal para a seleção entre uma modinha de salão e uma modinha de seresta. E, quando a obra circula do salão para a seresta? Que processos ocorrem na construção da linha melódica? Que alterações ocorrem no registro? E nas gravações? O que é possível perceber? Qual o papel do registro sonoro nessa investigação?

Andrade, em 1937, na comunicação feita no Congresso Nacional de Língua Cantada já apontava a importância das fontes sonoras como "material abundante de observação" considerando-o, inclusive, mais importante que a observação da grafia musical. Observa, ainda que "Nunca uma canção transcrita no papel ou no instrumento poderá dar a quem a estuda, a sua exata realidade”. A reflexão sobre questões interpretativas, na circulação, observa a construção da linha melódica e suas adaptações, levando-se em conta também o 
material sonoro com o objetivo de identificar aspectos de colocação vocal, dicção e prosódia e suas variações decorrentes do processo de circulação.

Ulhôa observa que, a partir da escuta do repertório de modinhas de tradição oral gravadas, é possível perceber que "algumas modinhas parecem ligadas a uma estrutura tradicional", ou seja, utilizam a estrutura de estrofes de quatro versos, têm uma sequência definida na melodia, um encaminhamento e uma frase conclusiva, e "outras divergem bastante deste modelo tradicional, sendo talvez adaptações de melodia de árias de ópera, zarzuelas ou operetas". (ULHÔA, 2008, p.7)

A modinha foi cantada e gravada por muitos intérpretes. Algumas das gravações com arranjos que se aproximam da música de câmara e outros mantendo a atmosfera da seresta.

Abaixo listamos as gravações de Róseas flores d'alvorada em ordem cronológica localizadas nessa pesquisa.

Tabela 37- Lista de gravações da modinha Róseas flores d'alvorada

\begin{tabular}{|c|c|c|c|}
\hline & Suporte - Álbum & Intérprete & Ano \\
\hline 1 & $\begin{array}{l}78 \text { rpm- The Art of Olga Praguer } \\
\text { Coelho }\end{array}$ & Olga Praguer Coelho & 1936 \\
\hline 2 & LP- Modinha Imperial & Lia Roberti & 1952 \\
\hline 3 & LP- Modinhas fora de moda & Lenita Bruno & 1960 \\
\hline 4 & LP - Uma noite de seresta vol.5 & Carlos José Ramos dos Santos & 1970 \\
\hline 5 & LP - Modinhas & Inezita Barroso & 1970 \\
\hline 6 & LP- Modinhas Imperiais & $\begin{array}{l}\text { Adélia Issa } \quad \& \quad \text { Alexandre } \\
\text { Paschoal }\end{array}$ & 1980 \\
\hline 7 & $\begin{array}{l}\text { LP -Mário de Andrade- trezentos, } 350 \\
\text { - disco } 2\end{array}$ & $\begin{array}{l}\text { Teca Calazans, Lenita Bruno, } \\
\text { Camargo Guarnieri \& Francisco } \\
\text { Mignoni }\end{array}$ & 1983 \\
\hline 8 & LP - Modinhas Imperiais & $\begin{array}{l}\text { Celia Coutinho \& Francisco } \\
\text { Mignoni }\end{array}$ & 1984 \\
\hline 9 & CD - Canções, modinhas e lundus & $\begin{array}{l}\text { Luis Alves da Silva \& Dolores } \\
\text { Costoyas }\end{array}$ & 1992 \\
\hline 10 & CD - Antigas Cantigas Brasileiras & Renato Motha e Patricia Lobato & 1999 \\
\hline 11 & CD - Modinhas Imperiais & Maria Lúcia Godoy & 2003 \\
\hline
\end{tabular}


Playlist da modinha disponível em :

Youtube:https://www.youtube.com/playlist?list=PLiVNvEjWK20L2OsR4H5oL1uthV $\underline{\text { WNqjicr }}$

Spotify: https://open.spotify.com/playlist/1vd25eDWwyTxGxQgPaPu8Z

Mário de Andrade, no livro Modinhas Imperiais, observa que essa composição possui influência italiana. "Estamos próximos de Bellini e Donizetti, e não do pior. Por outro lado, já se manifesta a tendência pros saltos grandes e desenhos melódicos arpejantes, que seriam depois normais no modinhismo popular" (ANDRADE,1980, p.3).

Curioso observar que, em algumas gravações, ela é classificada como uma modinha tradicional, ou seja, ligada à tradição popular, o que contraria as afirmações de Andrade, notando-se ainda a construção da linha melódica repleta de ornamentos.

Das onze gravações listadas podemos observar, por meio da escuta, que a maior parte das gravações tem características estéticas vocais que se aproximam do canto lírico. Inezita Barroso e Carlos José Ramos dos Santos utilizam a voz chamada voz de cantor de rádio, expressiva e sonora. Sob o ponto de vista do volume, o canto popular, até metade do século $\mathrm{XX}$, estava alinhado ao canto lírico. O aperfeiçoamento da captação pelo microfone e a proposta interpretativa de João Gilberto, na bossa nova, são fatores decisivos para transformar o padrão de emissão vocal do canto popular entre os anos de 1930 e 1950. A proposta de João Gilberto tem a emissão do canto mais próxima da fala. Patricia Lobo opta por uma voz sem ser empostada e com uso mínimo de vibrato (DUARTE,1994, pp.88-89).

Para Duarte, é possível classificar dois modelos teóricos de emissão vocal: "modelo da fala" e "modelo do canto", o que poderia ser observado, dentre outras variantes, como nível de impedância acústica, associando esforço expiratório com grau de resistência no trato vocal. A alta impedância seria responsável por maior sonoridade e a baixa impedância corresponderia a uma sonoridade mais próxima da fala (DUARTE, 1994, p.90).

Ao final do capítulo dois, observamos, nos documentos escritos, que as modinhas de salão utilizavam ornamentos na construção da linha melódica e as modinhas de seresta eram escritas tendo uma sílaba por nota musical. Se fossemos partir da classificação observada na construção da linha melódica, Róseas flores d'alvorada seria considerada uma modinha de salão; porém, quando ouvimos as gravações, essas classificações não puderam alcançar as interpretações.

Foi possível observar algumas combinações entre emissão vocal e construção melódica, criando um leque de opções interpretativas, isso sem observar os arranjos e/ou 
instrumentações utilizadas, que compõem o cenário musical.

Lenita Bruno, Adélia Issa, Lia Roberti, Celia Coutinho e Luis Alves cantaram a linha melódica com ornamentos, realizando o padrão vocal do canto lírico e arranjo de modinha de salão com instrumentação variada (piano, violão, orquestra). Olga Coelho também utiliza ornamentos e padrão vocal lírico, porém, realiza uma certa liberdade na ornamentação, apresentando algumas variações melódicas.

Inezita Barroso, embora utilize a linha melódica ornamentada, com certa liberdade, assim como Olga, realiza um padrão vocal sem empostação lírica, próxima da voz do cantor de rádio.

José Carlos apresenta a versão mais seresteira, sem ornamentação na linha vocal, sem empostação lírica e com arranjo instrumental característico de seresta.

Patricia Lobato, embora utilize as ornamentações presentes na partitura para voz e piano, não realiza o padrão vocal lírico empostado. Canta na região aguda; porém com emissão vocal com característica de voz "branca”, ou seja, uma voz sem empostação.

Rink observa que " a interpretação requer decisões -conscientes ou não - a respeito das funções contextuais de aspectos musicais específicos e dos meios de projetá-los" (RINK in CHUEKE, 2013, p.17).

Nessa perspectiva, reduzindo a análise somente ao padrão de emissão vocal e à construção da linha melódica, poderíamos relacionar pelo menos 12 possibilidades de escolha para o intérprete, combinando apenas alguns tipos de emissão vocal com a presença ou ausência de ornamentos na linha melódica. Considerando que o intérprete mantivesse o mesmo padrão de emissão durante toda a música, teríamos as opções:

Tabela 38- Tipos de emissão vocal

\begin{tabular}{|l|l|l|l|}
\hline $\begin{array}{l}\text { Tipo de emissão } \\
\text { vocal }\end{array}$ & & & \\
\hline Voz empostada & $\begin{array}{l}\text { Com ornamentação } \\
\text { idêntica à partitura }\end{array}$ & $\begin{array}{l}\text { Com ornamentação } \\
\text { variada }\end{array}$ & $\begin{array}{l}\text { Sem } \\
\text { ornamentação }\end{array}$ \\
\hline Voz “branca” & $\begin{array}{l}\text { Com ornamentação } \\
\text { idêntica à partitura }\end{array}$ & $\begin{array}{l}\text { Com ornamentação } \\
\text { variada }\end{array}$ & $\begin{array}{l}\text { Sem } \\
\text { ornamentação }\end{array}$ \\
\hline $\begin{array}{l}\text { Voz de cantor de } \\
\text { rádio }\end{array}$ & $\begin{array}{l}\text { Com ornamentação } \\
\text { idêntica à partitura }\end{array}$ & $\begin{array}{l}\text { Com ornamentação } \\
\text { variada }\end{array}$ & $\begin{array}{l}\text { Sem } \\
\text { ornamentação }\end{array}$ \\
\hline $\begin{array}{l}\text { Voz popular } \\
\text { (próximo à fala) }\end{array}$ & $\begin{array}{l}\text { Com ornamentação } \\
\text { idêntica à partitura }\end{array}$ & $\begin{array}{l}\text { Com ornamentação } \\
\text { variada }\end{array}$ & $\begin{array}{l}\text { Sem } \\
\text { ornamentação }\end{array}$ \\
\hline
\end{tabular}

Fonte: Elaborado para esse trabalho.

Além do tipo de emissão vocal e questões ligadas aos ornamentos na linha vocal, a 
construção da performance do canto envolve muitas outras escolhas como métrica, ajustes de letra e melodia, ritmo da prosódia, ou seja, ajustar tempos fortes com sílabas tônicas, articulação das vogais e das consoantes, controle respiratório para construção de fraseado, cuidado com afinação, tonalidade, nasalidade, escolhas das terminações, que podem ser femininas ou masculinas, peso dado aos acentos, estrutura das cadências e improvisos, recursos esses que não abordaremos neste trabalho, embora sejam de grande relevância na proposta de uma interpretação.

Lenine Santos em seu trabalho de doutorado, O Canto sem casaca, que tem objetivo didático, aborda aspectos relevantes para a construção de uma performance. Santos expõe 40 canções e apresenta tópicos como características interpretativas, sugestão de tonalidade e de andamento, de padrão de emissão vocal, de construção de fraseado, sugerindo caminhos para essas escolhas. (SANTOS, 2011)

Muitos dos intérpretes fazem essas escolhas inconscientemente, decorrentes da experiência, da vivência e do histórico. Atualmente, cada vez mais trabalhos vêm sendo escritos sobre o processo de interpretação, seja a preparação ou a análise posterior da performance. Chueke observa que “ os grandes instrumentistas não costumam verbalizar seja oralmente, e muito menos por escrito - suas experiências em torno do repertório com o qual trabalham". Ouvir, observar, ler, falar sobre a construção da performance, sem dúvida, enriquece o as percepções sobre questões interpretativas.

3.4 Questões interpretativas relacionadas à vocalidade na circulação da seresta para o salão

Analisaremos a modinha Amo-te muito, composta em 1910 por João Chaves (MG 1887 - MG 1970), poeta, compositor e instrumentista nascido na cidade de Montes Claros, em Minas Gerais.

A modinha está presente em duas fontes e ambas podem ser classificadas como publicações de seresta. A melodia foi encontrada no livro As Mais Belas Modinhas, de Milene Antonieta Coutinho Mauricio e no livro Minas Sempre-Viva de Luiz Claudio. 
Tabela 39- Informações sobre a modinha Amo-te muito

\begin{tabular}{|l|l|l|l|l|}
\hline Título & Primeira frase & Compositor & $\sim$ Poeta & Fonte \\
\hline Amo-te muito & Amo-te muito, como as João Chaves & João Chaves & Minas sempre-viva \\
\hline Amo-te muito & Amo-te muito, como as João Chaves & João Chaves & As mais belas modinhas \\
\hline
\end{tabular}

Fonte : Lista de modinhas

Observamos as datas de publicação conforme a tabela abaixo

Tabela 40- Ordem cronológica das fontes da modinha Amo-te muito

\begin{tabular}{|l|l|l|}
\hline & FONTE & $\begin{array}{l}\text { ANO DA PRIMEIRA } \\
\text { PUBLICAÇÃO }\end{array}$ \\
\hline A & As mais belas modinhas & 1976 \\
\hline B & Minas Sempre-viva & 1983 \\
\hline
\end{tabular}

Fonte: Lista de coletâneas

Portanto, a primeira publicação, em coletânea, que temos notícia, é datada de 1976, distando 66 anos da data da composição.

Tabela 41- Letras da modinha Amo-te muito nas fontes A e B

\begin{tabular}{|l|l|}
\hline As mais belas modinhas & Minas Sempre-Viva \\
\hline Amo-te muito & Amo-te muito \\
Amo-te muito, como as flores amam & $\begin{array}{l}\text { Amo-te muito, como as flores amam } \\
\text { O frio orvalho que o infinito chora }\end{array}$ \\
O frio orvalho que o infinito chora & Amo-te como o sabiá da praia \\
Amo-te como o sabiá da praia & Ama a sanguínea e deslumbrante aurora... \\
Ama a sanguínea e deslumbrante aurora... & Coro \\
Côro & $\begin{array}{l}\text { Oh! Não te esqueças } \\
\text { Que eu te amo assim }\end{array}$ \\
Oh! Não te esqueças que te amo assim &
\end{tabular}




\begin{tabular}{|l|l|}
\hline $\begin{array}{l}\text { Amo-te muito, como a onda a praia, } \\
\text { E a praia a onda que a vem beijar } \\
\text { Amo-te tanto como a branca pérola } \\
\text { Amo as entranhas do infinito mar... }\end{array}$ & $\begin{array}{l}\text { Oh! Não te esqueças } \\
\text { nunca mais de mim... }\end{array}$ \\
& $\begin{array}{l}\text { Amo-te muito, como a onda à praia, } \\
\text { E a praia à onda que a vem beijar... } \\
\text { Amo-te como a branca pérola }\end{array}$ \\
Amo-te muito, como a brisa aos campos & Ama as entranhas do infinito mar... \\
E o bardo a lua derramando luz & Amo-te muito, como a brisa aos campos \\
E Cristo amou ardentemente a Cruz... & E o bardo à lua derramando luz \\
Amo-te tanto como amo o gozo \\
E Cristo amou ardentemente a cruz...
\end{tabular}

Fonte: Coletâneas A e B

A letra possui pequenas variações de uma fonte para a outra. Observamos também a presença da repetição do coro na segunda fonte, o que não foi registrado na primeira fonte.

A partitura presente no livro de Milene Mauricio foi escrita em compasso quaternário e possui 16 compassos. Na transcrição do livro de Luiz Claudio, a música está em compasso binário e possui 33 compassos. Ambas estão em Dó maior.

A linha melódica das duas transcrições tem algumas diferenças. Como já explicitado anteriormente utilizaremos os graus da escala para demonstrar as diferenças e semelhanças nesse contorno.

Seguem abaixo as partituras. 
Figura 35- Partitura da modinha Amo-te muito na fonte A

\section{- Amo-te muito .}

Amo-te muito, como as flores amam

Letra o música de Joåo Chaves

0 frio orvalho que o infinito chora

Amo-te como o sabiá da praia

Ama a sanguínea e deslumbrante aurora...

\section{CORO}

Oh! Não te esqueças que te amo assim! Oh! Não te esqueças nunca mais de mim.

Amo-te muito, como a brisa a os campos E o bardo a lua derramando luz

Amo-te tanto como amo o gozo

E Cris to amou ardentemente a Cruz ...

Amo-te muito, como a onda a praia, E a praia a onda que a vem beijar Amo-te tanto como a branca pérola Amo as entranhas do infinito mar... Oh! Não te esqueças que te amo assim! Oh! Não te esqueças nunca mais de mim.

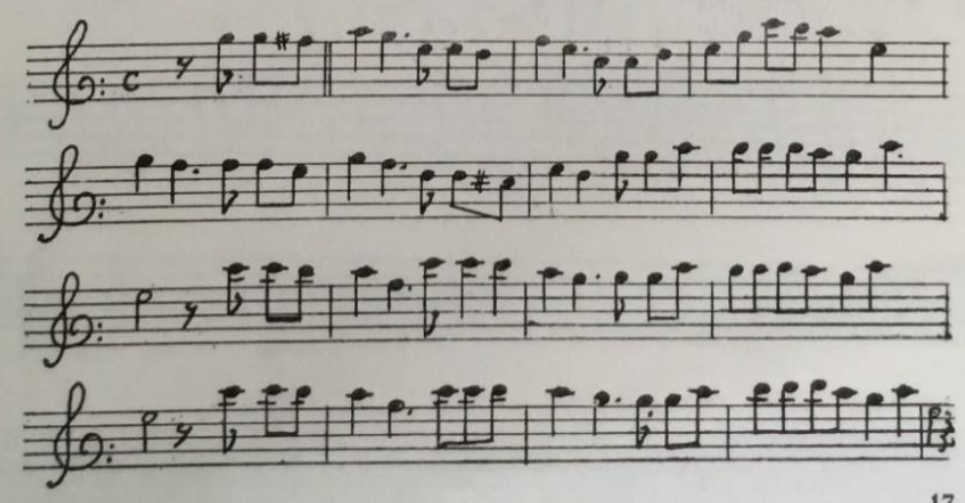




\section{$\underset{\text { Jodo Chaves }}{\text { Amo-te Muito }}$}
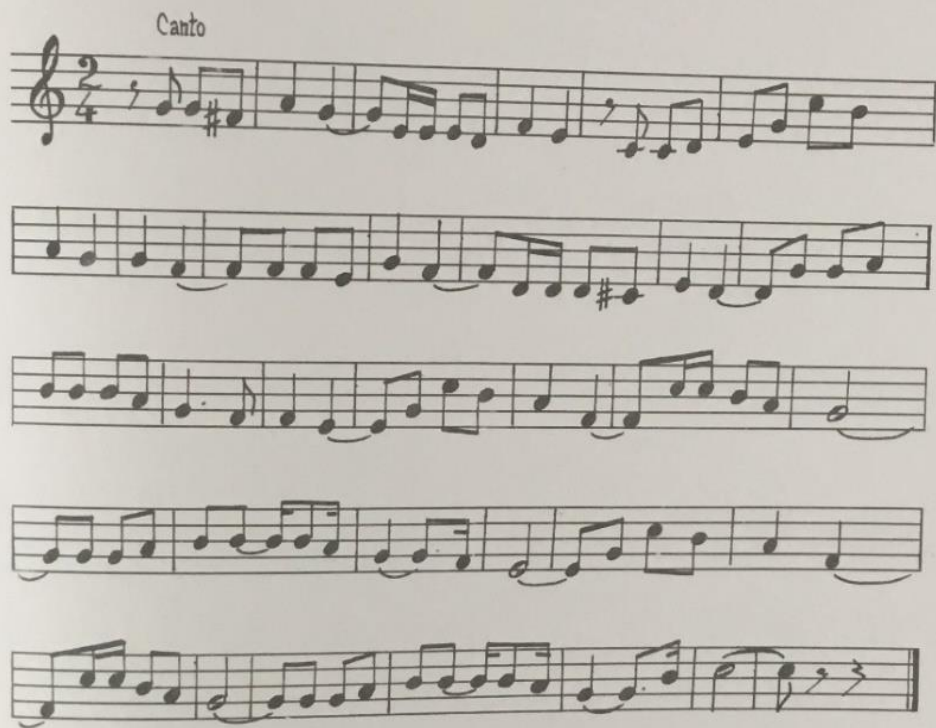

Amo-te muito, como as flores amam

o frio orvalho que o infinito chora...

Amo-te como o sabiá da praia

ama a sangưinea e deslumbrante aurora.

Amo-te muito como a onda à praia

e a praia à onda que a vem beijar.

Amo-te como a branca pérola

ama as entranhas do infinito mar.

(Coro)

Amo-te muito, como a brisa aos campos

e o bardo à lua derramando luz..

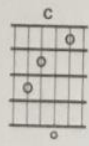

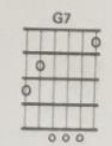

$\stackrel{F}{E \neq \neq \neq \neq \neq}$

00

Amo-te tanto quanto amo o gozo

Oh, não te esqueças c

que eu te amo assim.

Oh, não te esqueças

e Cristo amou ardentemente a cruz..

nunca mais de mim.

Fonte : Minas Sempre-viva

Como as modinhas estão escritas em fórmulas de compasso distintas a contagem será diferente. Chamaremos por trechos.

Trecho 1

Compasso de anacruse até compasso 8 (2 tempos) - fonte quaternária (A)

Compassos 1 ao 16 - fonte binária(B) 
Tabela 42- Contorno melódico de Amo-te muito- primeiro trecho nas fontes A e B

\begin{tabular}{|c|c|}
\hline A & $55 \# 4653324311235876354 \quad 4435422 \# 1325567776563$ \\
\hline B & $\begin{array}{lll}55 \# 465333243 & 11235876554 & 44354222 \# 132 \\
55677765443 & & \end{array}$ \\
\hline
\end{tabular}

Trecho 2

Compasso 8 (final) até o compasso 16(A)

Compassos 17 ao $33(\mathrm{~B})$

Tabela 43-Contorno melódico de Amo-te muito- segundo trecho nas fontes A e B

\begin{tabular}{|l|l|}
\hline & \\
\hline A & 8876488765556777656388764887655567776563 \\
\hline B & $\mathbf{5 8 7 6 4 8 8 7 6 5 5 5 6 7 7 7 6 5 4 3 5 8 7 6 4 8 8 7 6 5 5 5 6 7 7 7 6 5 7 8}$ \\
\hline
\end{tabular}

A maior parte das variações está na cadência ou na preparação da cadência. Há apenas uma variação no início da frase que, numa fonte inicia no quinto grau da escala e na outra, no oitavo grau da escala.

A modinha foi cantada e gravada por muitos intérpretes. Algumas das gravações com arranjos que se aproximam da música de câmara e outros que mantém a atmosfera da seresta.

Segue abaixo uma tabela de gravações da modinha Amo-te muito em ordem cronológica das gravações

Tabela 44 - Lista de gravações da modinha Amo-te muito

\begin{tabular}{|l|l|l|c|}
\hline & Álbum & Intérprete & Ano \\
\hline 1 & LP - Coral Ouro Preto & Coral de Ouro Preto & 1962 \\
\hline 2 & LP - Canções da minha terra & Ely Camargo & 1964 \\
\hline 3 & LP- Samba-Rancho ritmo e doçura & $\begin{array}{l}\text { Stellinha Egg e pequenos } \\
\text { cantores da Guanabara }\end{array}$ & 1964 \\
\hline 4 & LP- Lia Salgado e a canção brasileira & Lia Salgado & 1964 \\
\hline 5 & LP- Uma conversa e cinco modinhas & Grupo de seresta João Chaves & 1967 \\
\hline 6 & LP- Caatingas & Luiz Claudio & 1973 \\
\hline 7 & LP- Música popular do centro-oeste & Nara Leão & 1974 \\
\hline
\end{tabular}




\begin{tabular}{|c|c|c|c|}
\hline & sudeste & & \\
\hline 8 & $\begin{array}{l}\text { LP- Ovelha Negra- Trilha sonora da } \\
\text { Rede Tupi }\end{array}$ & Daisy de Souza & 1975 \\
\hline 9 & LP -Cantares Brasileiros I - A modinha & Luiz Claudio & 1976 \\
\hline 10 & LP-Aline & Aline & 1979 \\
\hline 11 & LP- - Aline & Silvio Brito & 1980 \\
\hline 12 & LP -Casa de Caboclo & Nara Leão & 1980 \\
\hline 13 & LP- Picadinho à brasileira & Grupo Banzé & 1981 \\
\hline 14 & LP- Minas Sempre-Viva & Luiz Claudio / Luiza & 1982 \\
\hline 15 & LP- Cantares de Minas & Maria Lúcia Godoy & 1982 \\
\hline 16 & LP- Olhares sem destino & Regis Clemente & 1985 \\
\hline 17 & LP- Canta Brasil & Coral Julia Pardini & 1986 \\
\hline 18 & LP- Mares de Minas & Aline & 1988 \\
\hline 19 & $\mathrm{CD}-\mathrm{O}$ aventureiro de São Francisco & Tavinho Moura & 1994 \\
\hline 20 & CD -Fulô da Laranjeira Vol.1 & Tadeu Franco /Saulo Laranjeira & 1998 \\
\hline 21 & CD- Coletânea vol.2 & Luiz Claudio & 1999 \\
\hline 22 & $\begin{array}{l}\text { CD - A música brasileira deste século } \\
\text { por seus autores e intérpretes }\end{array}$ & Pena Branca e Xavantinho & 2000 \\
\hline 23 & $\begin{array}{l}\text { CD- Memorial Wagner Tiso \& Zé } \\
\text { Renato }\end{array}$ & $\begin{array}{l}\text { Boca livre/ Zé Renato/ Wagner } \\
\text { Tiso }\end{array}$ & 2002 \\
\hline 24 & CD- Hoje Lembrando & Inezita Barroso & 2003 \\
\hline 25 & $\begin{array}{l}\text { CD -Teca Calazans \& Heraldo do } \\
\text { Monte }\end{array}$ & $\begin{array}{l}\text { Teca Calazans/Heraldo do } \\
\text { Monte }\end{array}$ & 2003 \\
\hline 26 & CD- Sabiá & Paula Santoro & 2003 \\
\hline 27 & CD- Este seu olhar & Luiz Claudio & 2005 \\
\hline 28 & CD - Serestas Brasileiras & Marcelo Barra & 2006 \\
\hline 29 & $\mathrm{CD}$ - Viola...violar & Marcos Vinícius, Ceumar & 2007 \\
\hline 29 & $\begin{array}{l}\text { CD- O canto e a poesia de João Chaves } \\
\text { e a música de Téo Azevedo }\end{array}$ & Agnaldo Timóteo & 2011 \\
\hline
\end{tabular}

A Playlist da modinha Amo-te muito foi elaborada para esse trabalho e está disponível em:

Youtube : https://youtu.be/Rymp-yRPay0 


\section{Spotify : https://open.spotify.com/playlist/4durTvejSrU6FhkTt3W4ca}

No segundo capítulo concluímos que, observando os registros escritos de todos os critérios elencados, acreditamos que a observação da construção da linha melódica fosse o critério principal para a seleção entre uma modinha de seresta e uma modinha de salão. E, quando uma obra circula da seresta para o salão? Que processos ocorrem na construção da linha melódica? Analisando a fonte sonora e não mais o documento escrito como fica a questão da vocalidade? Qual a escolha interpretativa?

Observando a partitura escrita por Camargo Guarnieri com arranjo da modinha Amo-te muito elaborado em 1958, com data anterior, portanto, às outras fontes, é possível perceber que não foram inseridos ornamentos como melismas, grupetos.

O compositor manteve a escrita da melodia de uma nota por sílaba. No arranjo, o baixo tem as melodias com o gesto que lembram o baixo do violão seresteiro. No início da partitura, Guarnieri indica "imitando violão".

A partitura logo abaixo, escrita por Camargo Guarnieri, tem o seguinte contorno melódico - fonte $\mathrm{C}$.

Tabela 45- Contorno melódico de Amo-te muito na fonte C

\begin{tabular}{|c|c|}
\hline $\mathrm{C}$ & 55\#465333\#243 $1123587635444354222 \# 132255677765443$ \\
\hline & $\begin{array}{lll}587648765 & 5567776543 & 5876487655567776543\end{array}$ \\
\hline
\end{tabular}

Encontramos mais semelhança com a fonte B, conforme comparação abaixo:

Trecho 1

Compassos 1 ao 16 fonte binária(B)

Compasso de anacruse até compasso 8 (2 tempos) - fonte quaternária (C)

Tabela 46- Contorno melódico de Amo-te muito- primeiro trecho nas fontes B e C

\begin{tabular}{|l|lll|}
\hline $\mathrm{B}$ & $55 \# 465333243$ & 11235876554 & $44354222 \# 13255677765443$ \\
\hline $\mathrm{C}$ & $55 \# 465333 \# 243$ & 11235876354 & $44354222 \# 13255677765443$ \\
\hline
\end{tabular}

Trecho 2:

Compassos 17 ao 33 (B)

Compasso 8 (final) até o compasso 12(C) com repetição. 
Tabela 47- Contorno melódico de Amo-te muito-segundo trecho nas fontes B e C

\begin{tabular}{|c|c|}
\hline B & 58764887655566777654358764887655567776578 \\
\hline $\mathrm{C}$ & $587648765 \quad 5567776543$ \\
\hline
\end{tabular}

Figura 37- $1^{\mathrm{a}}$ página da partitura da modinha Amo-te muito, arranjo de Camargo Guarnieri

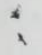

A Lia Salgado

AMO-TE MUITO

do filme "REBELIÃO EM VILA RICA"

ARRANJO DE CAMARGO GUARNIERI
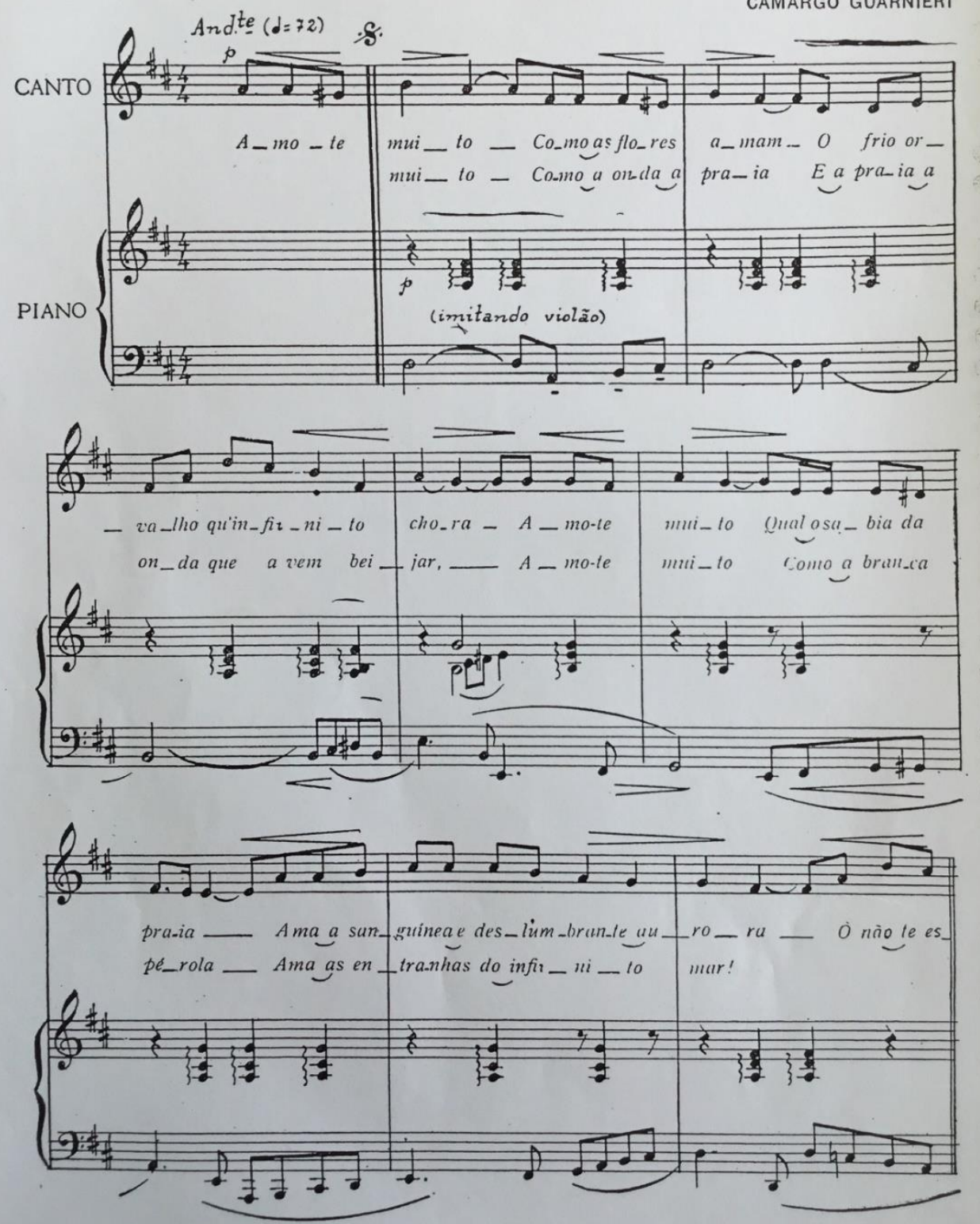

O Copyright 1958 by RICORDI BraSILEIRA S. A. - Al. Barõo de Limeiro, 331 - Säo Poulo - Brosil All rights reserved - International copyright secured . Printed in Brazil

Todos os direitos säo reservados. 
Figura $38-2^{\mathrm{a}}$ página da partitura da modinha Amo-te muito, arranjo de Camargo Guarnieri

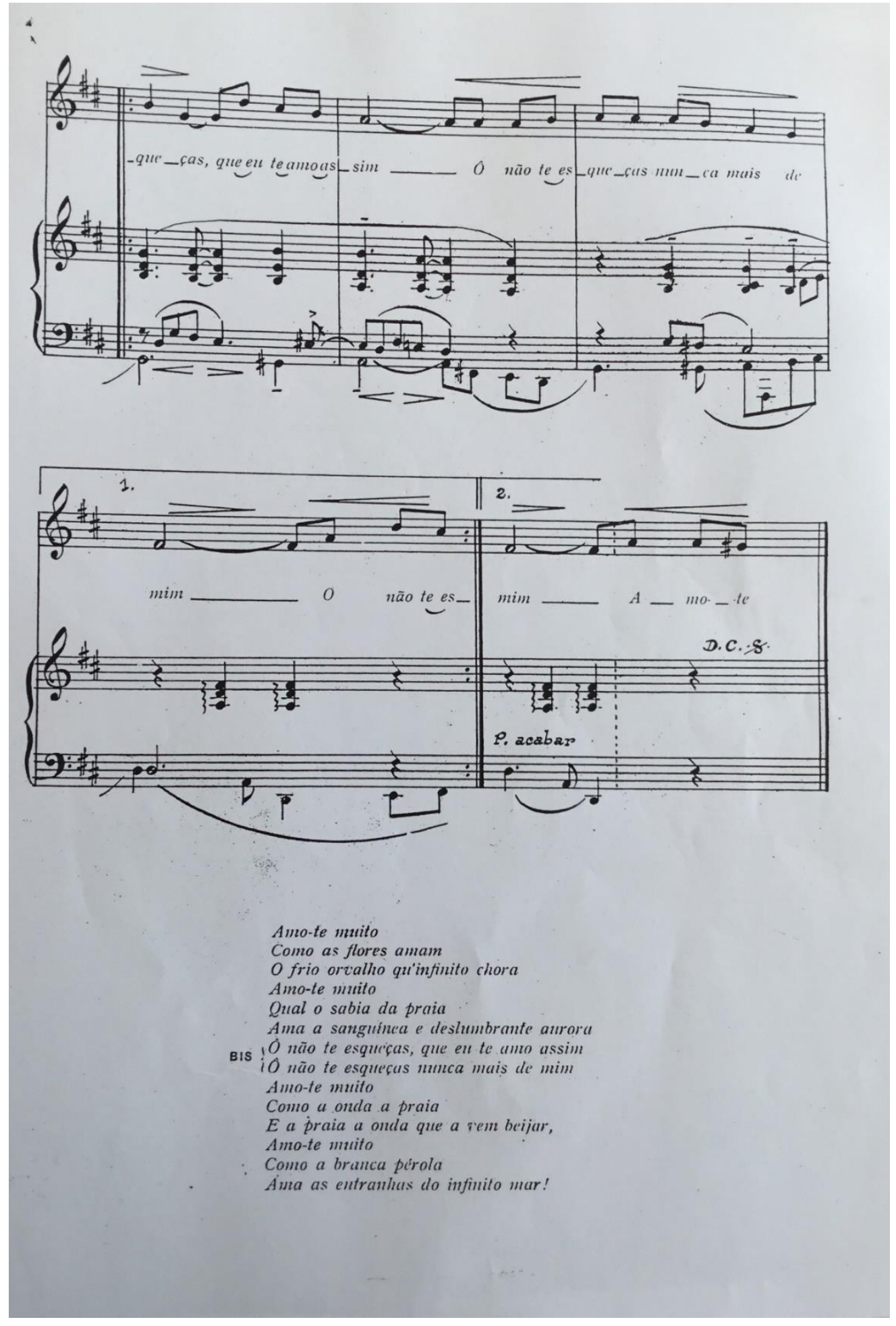

Observamos que, na circulação entre o oral e a partitura escrita por um compositor da academia, como Camargo Guarnieri, a modinha Amo-te muito não recebeu acréscimo de ornamentação. O compositor escreveu a melodia mantendo uma nota por sílaba e harmonizou. 
Embora a fonte do Camargo Guarnieri seja anterior às fontes que registraram apenas a melodia, observamos que a construção da linha melódica segue um padrão comum. Essa partitura poderia ser considerada uma modinha de salão? Se fôssemos seguir a proposta abordada no segundo capítulo, a resposta seria não. Nesse caso, continuaria uma modinha de seresta, pois embora um compositor que domina a escrita musical tenha arranjado para voz e piano aos moldes das modinhas de salão, a linha vocal permaneceu. E, se fôssemos observar do ponto de vista da interpretação? Será que ela seria considerada modinha de salão, uma vez que foi feita para uma soprano?

Para Andrade "O estudo dos discos de canto nacional abre desde logo uma distância amarga e ilegítima entre os cantores eruditos e os cantores...naturais”(ANDRADE, 1937, p.78).

Em 1964, foi feita a gravação da soprano Lia Salgado no LP Lia Salgado e a Canção Brasileira com harmonização de Camargo Guarnieri; no mesmo ano Ely Camargo também gravou no LP Canções da Minha Terra Vol.4, gravadora Chantecler . Ouvindo Ely Camargo e Lia Salgado podemos perceber as diferenças nas escolhas vocais de cada uma. Ely Camargo tem o canto mais próximo do que denominamos cantor de rádio, enquanto Lia Salgado utiliza a voz empostada do canto lírico. A gravação de Maria Lúcia Godoy utiliza a mesma colocação vocal de Lia Salgado. Um ouvinte desavisado, ao se deparar com a modinha cantada por Lia Salgado ou Maria Lúcia Godoy, consideraria essa modinha como uma modinha de salão? Possivelmente, sim. A colocação vocal é capaz de determinar a classificação de uma modinha? É capaz de fazê-la circular de seresta para salão? De popular para clássica $^{27}$ ?

Inezita Barroso, Raimundo Chaves, Moacir Franco, Agnaldo Timoteo, assim como Ely Camargo, utilizam a voz de cantor de rádio: sonoro, porém sem ser empostado. É possível que esse padrão de emissão seja o mais próximo do padrão utilizado pelos seresteiros. O grupo de serestas João Chaves, fundado em 1967, utilizou esse padrão vocal.

Nara Leão, Lui Coimbra, Ceumar, Tavinho Moura, Zé Renato e Paula Santoro utilizam o padrão de emissão vocal mais próximo da fala. Pena Branca \& Xavantinho utilizam a emissão vocal mais próxima à fala, mas incluem as aberturas em terças características da música caipira.

\footnotetext{
${ }^{27}$ Optamos por utilizar o termo clássico ao erudito. Música clássica, nesse caso, refere-se à música que não é popular. A palavra erudita, ex-rude, ou que deixou de ser rude, acabou sendo utilizada como juízo de valor, o que, de certa forma, cria uma imagem qualitativa de superioridade junto com o termo. Adotamos, portanto, a terminologia que vem sendo utilizado em artigos e trabalhos de música popular brasileira.
} 
Embora exista uma variedade de escolha de emissão vocal, não foram inseridos ornamentos como melismas ou grupetos, porém observamos portamentos, rubatos, vibratos, em algumas gravações. Os ornamentos, principal característica que havíamos elencado como diferença entre as modinhas de salão e de seresta, não foram incluídos nessas gravações.

Interessante observar as várias possibilidades que o intérprete tem nas escolhas não só vocais como de arranjos com outras vozes e possibilidades instrumentais. Se ouvirmos o início do arranjo gravado por Nara Leão e o início do arranjo gravado por Maria Lúcia Godoy, por um instante, poderemos esperar padrões vocais contrários. Como se esperássemos a emissão vocal de Nara Leão no arranjo de Maria Lúcia e o inverso também; ou seja, a emissão vocal de Maria Lúcia no arranjo de Nara Leão.

Dessa forma, consideraríamos todas essas gravações como modinhas de seresta? O arranjo seria capaz de estabelecer uma classificação? A emissão vocal o seria? E, quando aparecem variados, como na gravação de Nara Leão e Maria Lúcia Godoy? A estrutura utilizada na linha melódica, o arranjo, a emissão vocal, atualmente nenhum desses parâmetros é capaz de classificar uma modinha. E a questão que nos ocorre é: será necessário classificar uma modinha em popular ou clássica? De seresta ou de salão? Para efeito de catalogação, talvez fosse possível fazer essa separação, baseando-se apenas em material escrito; mas, quando se trata de intepretação tudo isso perde o sentido.

A liberdade do intérprete, enquanto co-criador, propicia a diversidade de versões.

\section{CONSIDERAÇÕES FINAIS}

Ao longo dessa pesquisa arriscamos dizer que é infrutífero, ou até impossível, precisar origens e verdades absolutas nesse processo de pesquisa da modinha. Essa impossibilidade é dada por muitos fatores, mas principalmente pela percepção do fluxo e refluxo cultural entre o Brasil e outros povos e pela própria movimentação interna sendo que a maior parte desse fluxo e refluxo se deu por tradição oral.

Uma vez que não possuímos memória documental musical de modinhas, no Brasil, antes do século XVIII, pois a imprensa regular iniciou em 1808, com a chegada da família real e ainda, por termos parte dos acervos em processo de organização, cremos que reunir dados sobre a modinha e analisá-los foi fundamental para o entendimento dessa "entidade" que inicialmente nos parecia abstrata, imprecisa e confusa, com informações presentes em diferentes fontes, tempos históricos, lugares e ideologias. 
Ulhôa levanta reflexões sobre a pertinência de categorias de análise no estudo de música popular. Reflete sobre quais princípios podem ser tomados como base para construir essa categorização. Nesse experimento, a autora utiliza critérios de avaliação descritos pelos usuários, no caso, ouvintes, de cada gênero. A coleta e a análise foram feitas em dois estágios e nesse processo foi importante identificar o que é valorizado pelos fãs do gênero a ser estudado; e, a partir do que for considerado relevante, buscar quais os parâmetros musicais correspondentes. A autora exemplifica que, para a música sertaneja, a voz é um elemento importante. Quando a voz sertaneja vem acompanhada com certos parâmetros como tessitura, nasalidade e guturalidade tende a ser considerada como indicador de estilo e referência. No rock, por exemplo o que é considerado importante é o som, que se refere à textura e ao timbre (ULHÔA, 2000).

Sem dúvida, deslocar os critérios de avaliação para os usuários é pouco comum na academia; mas, pode ser um caminho metodológico para a desconstrução entre o saber escrito e o saber oral, a academia e a comunidade, a musicologia e a performance. Se pensássemos de forma análoga ao experimento de Ulhôa, poderíamos, eventualmente, considerar as escolhas dos intérpretes como uma pista para identificar a pertinência de possíveis categorias da modinha.

Da mesma forma que não conseguimos precisar a origem da modinha, também não conseguimos classificá-la dentro dos padrões positivistas e estruturalistas e em que parte do estudo de música brasileira, inicialmente, foi calcado. Embora busquemos nos afastar de teorias como estas, acabamos inconscientemente por retornar a essa prática. Por diversas vezes fomos questionadas sobre a escolha da categorização da modinha na pesquisa. As questões levantadas em conversas por pesquisadores e intérpretes normalmente eram: por que dois tipos de modinha? Modinha não é tudo igual?

Algumas vezes, pensamos em alterar a linha de trabalho tratando o tema por outra abordagem que não a separação tipológica e a comparação. Conforme a pesquisa foi se desenvolvendo, acabamos por entender que esse processo de separar em tipos, seguido da abordagem comparativa, seria enriquecedor e nos daria embasamento para observar as interpretações. Será que poderíamos escolher um caminho para, em seguida, desconstruí-lo? Seria benéfico para a pesquisa? Apoiamo-nos no próprio percurso da musicologia no Brasil.

Entre os trabalhos dos pioneiros, vale a pena ressaltar, como característica geral, a separação tipológica que os orientam . Desta 
maneira, tradicionalmente temos no Brasil basicamente quatro campos musicológicos, correspondentes aos tipos linguágico-musicais "primitivo", “folk", “popular" e "artístico" (MENEZES BASTOS, 1990, p.67).

Segundo Menezes Bastos, após estudos que se basearam em separações tipológicas, os trabalhos de musicologia foram caminhando para relações interdisciplinares e começaram a ser produzidos nos cinco campos: Antropologia Sócio-Cultural, Sociologia e Política, História, Comunicações e Teoria Literária. Para o autor, "sem dúvida alguma que o país agora parece maduro para uma definitiva consolidação acadêmico-universitária de uma Musicologia do Brasil congenitamente interdisciplinar". Mas onde está o elemento sonoro nesse processo? E o intérprete?

Vilela, em seu artigo Ouvir a música como experiência imprescindível para se fazer musicologia, aponta que é comum encontrar estudos musicológicos que tomam o material escrito como base da pesquisa esquecendo-se de considerar a música em si. Destaca a importância dos textos já construídos; porém, observa que o estudo com base na literatura, dissociada da escuta, pode causar perpetuação de equívocos. Para o autor, "a experiência da fruição entra aqui como um procedimento imprescindível no escrever sobre música, pois a percepção obtida disso amplia o entendimento do objeto" (VILELA, 2014, p.130).

Embora Vilela esteja se referindo mais especificamente ao estudo da música popular, entendemos que, para observar e estudar uma obra, gênero ou movimento musical é necessário ouvi-la. Dahlhaus nos convida a essa reflexão sobre a importância do som na linguagem musical quando expõe que “ o sentido musical diversamente do verbal, não é separável ou, então, só em escassa medida, do facto sonoro. A composição, para se tornar musicalmente real, precisa de interpretação sonora (DAHLHAUS, 2003, p.24).

Determinar a classificação da modinha entre música popular, música folclórica, música clássica ou artística parece impossível agora, após ouvir as várias gravações das modinhas Róseas flores d'alvorada e Amo-te muito listadas no terceiro capítulo. É possível, sim, separá-las e compará-las observando apenas o material escrito. E também, listando coletâneas, identificando épocas de composição, movimentos literários a que pertencem os poetas, escola dos compositores, e, mesmo, os contextos sociais, políticos, ideológicos e históricos, e até arriscar gêneros ou estilos por meio da análise do material musical escrito. Mas, ao considerar uma interpretação por meio da escuta, abre-se um novo campo de observação que perpassa do escrito para o sonoro. Nesse caminho, somos conduzidos pelo 
intérprete, pelo seu olhar, por sua análise.

Com efeito, a riqueza de uma obra reside na variedade de interpretações que ela inspira. Esta é origem do nosso fascínio, levando-nos a revisitá-la inúmeras vezes, escutando diferentes aspectos, descobrindo diferentes nuances e detalhes, sempre registrando aqueles elementos mágicos; a verdadeira essência da obra de arte. Estes elementos quando percebidos e transferidos para a execução, sem que ninguém os consiga explicar, comprovam a pertinência de uma interpretação (CHUEKE, 2013, p.11).

Chueke destaca que o intérprete percebe aspectos e nuances e os transfere para a execução. Observa ainda, que essa transferência acontece sem que ninguém consiga explicar a pertinência de uma interpretação. Pensamos que a pertinência de uma interpretação também está ligada à individualidade, ou seja, como cada um sente e percebe a obra que irá interpretar. Especificamente, no caso das modinhas, poderíamos supor que, como havíamos considerado anteriormente, o fato de o gênero ter atravessado três séculos e ter circulado espaços diversos, bem como estratos sociais distintos, num constante fluxo e refluxo, tenha possibilitado essa liberdade de criação. Soma-se ainda, a ausência de métodos de ensino voltados ao repertório brasileiro, quer sejam de canto ou de instrumento. Essa ausência, de certa forma, deixa as interpretações mais livres, fora de um padrão orientado por uma escola.

Tentar determinar uma interpretação válida, interpretação ideal ou modelo não caberiam na variedade de gravações dessas duas modinhas que ouvimos no terceiro capítulo. Pudemos perceber que o padrão de emissão vocal é variado. A hipótese inicial de que a presença de ornamentos, a construção melódica e o padrão vocal poderiam ser elementos que separariam a modinha de salão da modinha de seresta, não foi validado por meio da escuta.

Nesses exemplos, separamos três: um mais próximo da fala, outro com empostação e ainda um com padrão semelhante ao utilizado no que é chamado de voz de cantor de rádio. O tipo de arranjo vocal também, arranjos para voz solo, duas vozes em terças caipiras, duas vozes com outras combinações de intervalos e arranjos com a presença de coro.

A instrumentação varia muito também. Percebemos arranjos com presença de piano, violão, viola, bandolim, flauta, violoncelo, rabeca, percussão e orquestra. Nas interpretações não foi percebida a rigidez que os livros sobre modinha sinalizam na descrição dos instrumentos que são utilizados para acompanhar o canto. Olga Coelho, em 1936, grava Róseas flores d'alvora e Hei de amar-te até morrer, modinhas que são consideradas de salão 
e fazem parte da coletânea de Mário de Andrade. Nessa gravação, canta com voz empostada acompanhada ao violão. Percebemos uma liberdade de criação e de arranjo em maior número na modinha Amo-te muito que na modinha Róseas flores d'alvorada; e, sem dúvida, foi uma surpresa ouvir esse arranjo da Olga sabendo que somente 6 anos separam essa gravação da edição do livro de Modinhas Imperiais de Mário de Andrade.

Mas afinal, existe relação entre o estudo do objeto e sua interpretação? Por que um intérprete se ocuparia dessa pesquisa? Rothstein observa que o objetivo do intérprete nessas buscas não é mera curiosidade, mas, sim, no intuito de descobrir ou criar uma narrativa musical (ROTHSTEIN in CHUEKE, 2013, p.115).

Acreditamos que o exercício da pesquisa e a produção de material decorrente de reflexão sobre o objeto de estudo, possa dar ao intérprete a oportunidade de observar as análises teóricas e combiná-las com suas análises na construção da performance. Porém, observando os processos de interpretação nas modinhas, por meio de diversas gravações, percebemos que o uso desse material e o que será construído musicalmente, caberá ao intérprete escolher. E ele precisa ter liberdade e autonomia para tanto. 


\section{BIBLIOGRAFIA}

Referências bibliográficas

ALFERES, Sidnei. A "Collecção de modinhas de bom gosto" de João Francisco Leal: um estudo interpretativo por meio de sua contextualização histórico-estético-musical. Dissertação (Mestrado em Música). Campinas: Universidade Estadual de Campinas (UNICAMP), 2008.

ALENCAR, Edigar de. A Modinha Cearense. Fortaleza: Imprensa Universitária do Ceará,1967.

ALMEIDA, Adriana. Modinhas no Brasil Imperial: Ornamentação sob a influência dos castrati. Dissertação (Mestrado em Música). Campinas: Universidade Estadual de Campinas (UNICAMP), 2014.

ALVARENGA, Oneyda. Música Popular Brasileira.1 ed. 2 reimpressão. Porto Alegre: Editôra Globo, 1960.

ANDRADE, Mário. Dicionário Musical Brasileiro. Belo Horizonte: Editora Itatiaia Ltda, 1989.

Modinhas Imperiais. 3 ed. Belo Horizonte: Editora Itatiaia Ltda, 1980.

Música Brasileira por Mário de Andrade. A República, Rio Grande do Norte, 1928 in Imburana Revista do Núcleo Câmara Cascudo de Estudos Norte-RioGrandenses/UFRN. n. 11, jan./jun.2015.

ARAUJO, Mozart de. A Modinha e o Lundu. São Paulo: Ricordi Brasileira, 1963.

BLOMBERG, Carla. Histórias da Música no Brasil e musicologia: uma leitura preliminar. Música e Artes. Projeto História - Revista do Programa de Pós-Graduados de História no 43, PUC-SP,2011,414-444. Disponível em < http://revistas.pucsp.br/index.php/revph/article/view/8040> Acesso em: 16.06.2016.

BRITO, Fátima de. Caderno de Modinhas - Uma proposta para o estudo da canção brasileira (voz aguda, média e grave). Maceió: EDUFAL,2013.

CASTAGNA, Paulo. Introdução ao estudo da música (erudita) no Brasil. Apostila de História da Música Brasileira. v.1.UNESP,2003.

A Modinha e o Lundu nos Séculos XVIII e XIX. Apostila de História da Música Brasileira. v.9.UNESP,2003.

CEARENSE, Catullo da Paixão. Cancioneiro Popular de modinhas brasileiras. 25 ed. Rio de 
Janeiro: Livraria do Povo - Quaresma \& C. Livreiros Editores, 1908.

Modinhas: 3ed. São Paulo: Fermata do Brasil, 1972.

CHARTIER, Roger. Cultura escrita, literatura e história. Porto Alegre: Artmed, 2001

A História Cultural entre práticas e representações. Lisboa: Difel,2002.

CHUEKE, Zelia(Org).Leitura, Escuta e Interpretação.Curitiba:Ed.UFPR,2013.

CLAUDIO, Luiz. Minas Sempre-Viva: Pesquisa Histórica do Folclore Musical Mineiro. Rio de Janeiro: Léo Christiano Editorial Ltda., 1983.

COOK, Nicholas. Beyond the Score: Music as Performance. Oxford. Oxford University Press, 2014.

CORTEZ, Elsa Regina da Silva, Chansons de Mer - Charels-Marie Widor e Paul Bourget. Dissertação (Mestrado em música). Lisboa: Escola Superior de Música de Lisboa, 2012.

DAHLHAUS,CARL. Estética musical. Lisboa: edições 70, 2003.

DEBRET, Jean Baptiste,1768-1848. Viagem pitoresca e histórica ao Brasil v.III. Trad. e notas de Sérgio Milliet/ apresentação de M.G. Ferri. São Paulo: Editora Itatiaia Limitada, 1978.

DUARTE, Fernando J.C. A fala e o canto no Brasil: Dois modelos de Emissão vocal. Arte Unesp, nº16, pp.87-97, São Paulo: UNESDP,1994.

ESPASIANI, Jobi. Educação musical: leitura de estudos sobre a modinha de salão carioca da primeira metade do século XIX. Dissertação (Mestrado em educação). São Paulo: Universidade de São Paulo (USP), 2016.

FERRETTI, Sérgio. Repensando o sincretismo. 2 ed. São Paulo: EDUSP,2013.

GALVÃO, Claudio. A modinha norte-rio-grandense. Natal: EDUFRN, 2000.

GONZAGA, Tomás Antonio. Marilia de Dirceu.Lisboa: Typografia Nunesiana, 1792.

HOUAISS, Antonio, VILAR, Mauro de Salles, Dicionário Houaiss da Língua Portuguesa. Rio de Janeiro. Editora Objetiva Ltda., 2007.

IGAYARA-SOUZA, Susana. Entre palcos e páginas: a produção escrita por mulheres sobre música na história da educação musical no Brasil (1907-1958). Tese (Doutorado em Educação). São Paulo. Faculdade de Educação da Universidade de São Paulo (USP), 2001. 
KIEFER, Bruno. A Modinha e o Lundu: Duas Raízes da Música Popular Brasileira. Porto Alegre: Editora Movimento,1 977.

KIEFFER, Ana Maria. Apontamentos musicais dos viajantes. In: Revista da USP, São Paulo,30, jun./ago., 1996, p. 134-141.

LAFORGE, Pierre. Collecção Modinhas Brazileiras com Accompanhamento de Piano de varios autores. Rio de Janeiro, 1842.

LIMA, Edilson de. As Modinhas do Brasil. São Paulo: EDUSP, 2001.

A modinha e o Lundu: dois clássicos nos trópicos. 2010. Tese de Doutorado. Universidade de São Paulo, São Paulo, 2010.

MARQUES, Fernandina. A verdadeira história da modinha " A casa branca da Serra". Rio de Janeiro: Pongetti, 1972.

MAURICIO, Milene Antonieta Coutinho. As Mais Belas Modinhas. Montes Claros: Espaço Gráfica e Editora,1976.

Oficial, 1982.

- As Mais Belas Modinhas: II Volume. Imprensa

MELLO, Paulo Pimenta de. Modinhas \& Serestas valsas \& Canções. Ribeirão Preto: PlastSet, 1985.

MELLO, Guilherme. A música no Brasil desde os tempos coloniaes até o primeiro decênio da República. Bahia: Typographia de S. Joaquim, 1908. Disponível em: https://archive.org/stream/amusicanobrasil00mellgoog\#page/n9/mode/2up Acesso em 01.11.2017.

MENDES, Eunice Evanira Pereira. Contribuição para o estudo da modinha. São Paulo: Prefeitura do Municipio de São Paulo, Secretaria da educação e cultura -Divisão do arquivo histórico, 1959.

MENDES, Julia de Brito. Canções populares do Brazil. Rio de Janeiro: J. Ribeirdo dos Santos, Livraria Cruz Coutinho, 1911.

MORAES FILHO, Melo. Serenatas e Saráus. Rio de Janeiro: Livraria Garnier, 1901.

MORAIS, Guilherme. Realização de baixos em modinhas do "Jornal de Modinhas" com acompanhamento de cravo pelos milhores autores" editado por F.D. Milcent e P.A. Marchal - Lisboa, 1792-1797. Dissertação (Mestrado em Música). Campinas: Universidade Estadual de Campinas (UNICAMP), 2009.

MORAIS, Manuel, Modinhas, Lundus e Cançonetas. Lisboa, Portugal. Imprensa Nacional - 
Casa da Moeda, 2000.

NEVES, Eduardo das. Mysterios do violão. Rio de Janeiro: Livraria do Povo,1905.

PACHECO, Alberto José Vieira. Cantoria Joanina: prática vocal carioca sob influência da corte de D. João VI, castrati e outros virtuoses. São Paulo: Annablume; Fapesp, 2009.

PEDREIRA, Esther. Lundus e Modinhas antigas: Século XIX. Rio de Janeiro: Edições Tempo Brasileiro, 1981.

PINTO, Maria Sylvia. A canção brasileira. Rio de Janeiro: Companhia Brasileira de artes gráficas, 1985.

PIMENTA FILHO, Ruy. Modinhas antigas. Belo Horizonte: Editora Veja S.A., 1980.

PONTES, Jose Vieira. Lyra Popular brasileira. São Paulo: C. Teixeira \& Cia Editores, 1927.

RAMOS, Raimundo. Cantares Bohêmios. Fortaleza: Expressão Gráfica. 2006.

REZENDE, Angelica de. Modinhas de nossa terra. Belo Horizonte: Carneiro \& Companhia Editores, 1954.

RINK, John. (Ed.) Musical Performance: A Guide to Understanding. Cambridge: Cambridge University Press, 2002.

. The Practice of Performance: Studies in Musical Interpretation. Cambridge;

Cambridge University Press, 1995.

RIO, João do. A alma encantadora das ruas: crônicas; organização Raul Antelo. São Paulo: Companhia das Letras, 2008.

ROMERO, Sílvio. A História da Literatura Brazileira, Rio de Janeiro: B.L. Garnier, 1888.

SALLES, Vicente. A Modinha no Grão-Pará: estudos sobre ambientação e (re) criação da Modinha no Grão-Pará.Belém: Secult/IAP/AATP,2005.

SILVA, Joaquim Norberto de Souza. Nova colecção de modinhas brasileiras. Rio de Janeiro: Livraria Garnier, 1878.

Janeiro: Livraria Garnier, s.d. Nova colecção de Hymnos, canções e lundus. Rio de

SILVA JUNIOR, Jonas Alves da. Doces Modinhas pra Iaiá, Buliçosos Lundus pra Ioiô: Poesia Romântica e Música Popular no Brasil do Século XIX. São Paulo: Linear B; Faculdade de Filosofia, Letras e Ciências Humanas, 2008. 
SIQUEIRA, Baptista. Modinhas do Passado. 2ed. Rio de Janeiro: Folha Carioca Editora Ltda, 1979.

TINHORÃO, José Ramos. Pequena História da Música Popular: Da Modinha à Canção de Protesto. Petrópolis: Editora Vozes Ltda, 1974.

ULHÔA, Martha Tupinambá. Estilo e emoção na canção - notas para uma estética da música brasileira popular. CaderNOSdeEStudo: AnálisEmusical 8/9. Belo Horizonte,Atravez v. $8 / 9, \quad$ p.30-41, $1995 . \quad$ Disponível em <http://www4.unirio.br/mpb/ulhoatextos/Estilo_e_emocao_na_cancao_Versao_online.pdf > Acesso em: 19.06.2016.

Pertinência e música popular - Em busca de categorias para análise da música brasileira popular. In: III CONGRESO LATINOAMERICANO IASPM, 2000, Bogotá, Colômbia. ACTAS DEL III CONGRESO LATINOAMERICANO IASPM. Santiago, Chile: Asociación Internacional para el Estudio de la Música Popular - Rama Latinoamericana 2000.p. 1-13.

Inventando Moda - a construção da música brasileira. ICTUS (PPGMUS/UFBA), v.8,p.1-14,2007.

Matrizes - Música Popular no início do Século XIX no Rio de Janeiro. Partituras, performance e escuta da música popular do passado. EVP University of Texas at Austin. Austin, 2008. Disponível em http://docplayer.com.br/6810790-Matrizesmusica-popular-no-inicio-do-seculo-xix-no-rio-de-janeiro-partituras-performance-e-escutada-musica-popular-do-passado.html. Acesso em 15.08.2016.

Perdão Emilia! Transmissão oral e aural na canção popular. In: Matos, Cláudia; Travassos, Elizabeth; Medeiros, Fernanda. (Org.). Palavra cantada: ensaios sobre poesia, música e voz. Rio de Janeiro: 7Letras, 2008, p. 249-267.

VALE, Flausino Rodrigues. Elementos de Folclore Musical Brasileiro. 2ed.São Paulo: Companhia Editorial Nacional, 1978.

VALENÇA, José Rolim. Modinha: Raízes da Música do Povo. São Paulo: Empresas Dow, 1985.

VEIGA, Manuel. O Estudo da Modinha Brasileira. Study Session 7 : Portuguese usical outreach: five centuries. $16^{\text {th }}$ International Congress International Musicologic Society (14 a 20.08.97) Londres, 1997. Disponível em http://hugoribeiro.com.br/biblioteca-digital/VeigaModinha-LAMR.pdf acesso em 07.08.2015.

Achegas para um Sarau de Modinhas Brasileiras. Revista de Cultura da

Bahia. Salvador, 1998.v.17, p.77-122. Disponível em http://docplayer.com.br/20742278Achegas-para-um-sarau-de-modinhas-brasileiras-manuel-veiga.html acesso em 07.08.2015. 
Impressão musical na Bahia. Anais do V Encontro de Musicologia Histórica Juiz de Fora 19 a 21 de Julho de 2002, Juiz de Fora, v. 5, p. 360-398, 2004.Disponível em http://www.nemus.ufba.br/artigos/imb.htm Acesso em 15.03.2018.

Problemática da transmissão. Estudo de caso com ajuda dos poetas. Anais do XVIII Congresso da Associação Nacional de Pesquisa e Pós-Graduação (ANPPOM) Salvador, 2008. $\quad$ Disponível em https://antigo.anppom.com.br/anais/anaiscongresso_anppom_2008/posteres/POS389\%20\%20Veiga.pdf Acesso em 04.02.2018.

VIEIRA, Ernesto. Diccionario musical com gravuras e exemplos de música. Lambertini,Fornecedor da Casa Real. Typ. Lallemant, Lisboa:1899.

VILELA, Ivan. Cantando a Própria História: Música Caipira e Enraizamento. São Paulo: EDUSP, 2013.

Canonizações e esquecimentos na música popular brasileira. In. REVISTA USP, No111, p.124-134, out/nov/dez. São Paulo,2016. Disponível em http://www.revistas.usp.br/revusp/article/view/127607 acesso em 11.05.2018

Ouvir a música como experiência imprescindível para se fazer musicologia. Revista Música em Perspectiva, Curitiba, v.7, n.2, pp.101-131, dez, 2014.

Discografia

ALINE. Aline(intérprete). Independente.1979.LP

A MÚSICA BRASILEIRA DESTE SÉCULO POR SEUS AUTORES E INTÉRPRETES. Pena Branca e Xavantinho (intérprete). Sesc São Paulo.2000.CD.

ANTIGAS CANTIGAS BRASILEIRAS. Renato Motha (intérprete); Patricia Lobato (intérprete) Independente.1999.CD.

CAATINGAS. Luiz Claudio.Odeon. 1973.LP.

CANÇÕES, MODINHAS E LUNDUS. Luis Alves da Silva (intérprete); Dolores Costoyas (intérprete)Pan classics.1984.CD.

CANÇÕES DA MINHA TERRA. Ely Camargo (intérprete).Chantecler.1964.LP.

CANTA BRASIL. Coral Julia Pardini (intérprete). Bemol.1986.LP.

CANTARES BRASILEIROS I - A MODINHA. Luiz Claudio (intérprete).Independente. 1976. LP 
CANTARES DE MINAS. Maria Lúcia Godoy (intérprete).Independente.1982.LP.

CASA DE CABOCLO. Nara Leão. Marcos Pereira.1980.LP.

COLETÂNEA VOL.2. Luiz Claudio (intérprete).Independente.1999.CD.

CORAL OURO PRETO. Coral Ouro Preto (intérprete).Polydor. 1962.LP.

ESTE SEU OLHAR. Luiz Claudio (intérprete). Revivendo.2005.CD.

FULÔ DA LARANJEIRA. VOL.1. Tadeu Franco (intérprete); Saulo Laranjeira (intérprete).. Laranjeira Produções.1988.CD.

HOJE LEMBRANDO. Inezita Barroso (intérprete).Trama.2003.CD.

LIA SALGADO E A CANÇÃO BRASILEIRA. Lia Salgado. Chantecler.1964.LP.

MARES DE MINAS. Aline (intérprete).Independente.1988.LP.

MÁRIO DE ANDRADE - TREZENDOS, 350. DISCO 2. Teca Calazans (intérprete); Lenita Bruno (intérprete); Camargo Guarnieri (compositor); Francisco Mignoni (compositor). Funarte.1983.LP.

MEMORIAL WAGNER TISO \& ZÉ RENATO. Boca livre (intérprete); Zé Renato (intérprete); Wagner Tiso (intérprete). Biscoito Fino.2002.CD.

MINAS SEMPRE-VIVA. Luiz Claudio (intérprete). Luiza (intérprete).EMI Odeon. 1982.LP.

MODINHAS FORA DE MODA. Lenita Bruno (intérprete).Festa.1960.LP.

MODINHA IMPERIAL. Lia Roberti (intérprete).Copacabana.1952.LP.

MODINHAS. Inezita Barroso (intérprete). Continental.1970.LP

MODINHAS IMPERIAIS. Adélia Issa (intérprete); Alexandre Paschoal (intérprete).Eldorado.1980.LP.

MODINHAS IMPERIAIS. Célia Coutinho (intérprete); Francisco Mignoni (intérprete).Independente.1984.LP.

MODINHAS IMPERIAIS. Maria Lúcia Godoy (intérprete).Independente 2003.CD

MÚSICA POPULAR DO CENTRO-OESTE SUDESTE. Nara Leão(intérprete).Marcos Pereira.1974.LP. 
O AVENTUREIRO DE SÃO FRANCISCO. Tavinho Moura. Warner music. 1994.CD.

OLHARES SEM DESTINO. Regis Clemente.Independente.1985.LP.

PICADINHO À BRASILEIRA. Grupo Banzé (intérprete).Clack.1981.LP.

SAMBA-RANCHO RITMO E DOÇURA. Stellinha Egg e pequenos cantores da Guanabara (intérprete).Polydor. 1964.LP.

SERESTAS BRASILEIRAS. Marcelo Barra.Independente.2006.CD.

O CANTO E A POESIA DE JOÃO CHAVES E A MÚSICA DE TÉO DE AZEVEDO. Agnaldo Timóteo (intérprete). Independente.2011.CD.

OVELHA NEGRA- TRILHA SONORA DA REDE TUPI. Daisy de Souza (intérprete). Teletema/Continental.1975.LP.

SABIÁ. Paula Santoro (intérprete). Independente. 2003.CD.Produzido pela empresa Valée.

TECA CALAZANS \& HERALDO DO MONTE. Teca Calazans(intérprete); Heraldo do Monte (intérprete).Kuarup. 2003.CD.

THE ART OF OLGA PREGUER COELHO. Olga Praguer Coelho (intérprete).Guitarcoop. 2018. CD. 1936.Rpm. Digitalizado pela Guitarcoop.

UMA CONVERSA E CINCO MODINHAS. Grupo de seresta João Chaves.Marcos Pereira. 1967.LP.

UMA NOITE DE SERESTA vol.5. Carlos José Ramos dos Santos.CBS.1970.LP.

VIOLA...VIOLAR. Marcos Vinicius (intérprete); Ceumar (intérprete).Discantica records. 2007.CD.

Vídeos

ALENCAR, Edigar de .Depoimento para o Museu Fonográfico do Ceará. Miguel Angelo de Azevedo. Fortaleza,Ceará,abril,1972 disponível em

https://www.youtube.com/watch?v=Y0G6hN597Ig acesso em 20.02.19 
Material de Consulta

AMORA, Antônio Soares; CAVALHEIRO, Edgard. Panorama da Poesia Brasileira, Rio de Janeiro: Editora Civilização Brasileira, 1959.

AZEVEDO FILHO, Leodegário Amarante de. Base teórica de crítica textual. 2. ed. Rio de Janeiro: H. P. Comunicação, 2004.

BARBOSA, Domingos Caldas. Viola de Lereno: Collecção das suas cantigas oferecidas aos seus amigos (vol 1). Lisboa: Officina Nunesiana, 1798.

Viola de Lereno.Rio de Janeiro: Imprensa Nacional, 1944.

BARRENECHEA, Lúcia. Pesquisa no Brasil: balanços e perspectivas. OPUS - Revista da Anppom. Campinas, n. 9, p. 113-118, dez. 2003.

BONDIA, Jorge Larrosa. Notas sobre a experiência e o saber de experiência. Rev. Bras. Educ. [online]. Trad. João Wanderley Geraldi. Campinas: 2002, n.19, pp. 20-28.

CEREJA, William Roberto; MAGALHÃES, Thereza Anália Cochar. Panorama da Literatura Portuguesa. 2ed. São Paulo: Atual, 1997.

CHASIN, Ibaney. O Canto dos Afetos: Um dizer humanista. São Paulo: Perspectiva, 2004.

FREIRE, Vanda. Pesquisa em música e Interdisciplinaridade. Música Hodie. Goiânia, vol.10, $\mathrm{n}^{\circ} 1$, p. 81-92, 2010.

FREITAG, Léa Vinocur. Momentos de Música Brasileira. São Paulo: Nobel: CLOCK S.A., 1985.

GARMES, Hélder, SIQUEIRA, José Carlos. Cultura e memória na literatura Portuguesa. Curitiba: IESDE Brasil, S. A., 2009.

MARIN, Louis. Sublime Poussain. São Paulo: EDUSP, 2000.

MENEZES BASTOS, Rafael José de. Musicologia no Brasil, Hoje. BIB, Rio de Janeiro, n. 30,pp . 66-74, $2{ }^{\circ}$ sem estre de 1990

MARIZ, Vasco, A Canção Brasileira de Câmara. Rio de Janeiro: Livraria Francisco Alves Editora S.A., 2002.

MASSAUD, Moisés. A Literatura Portuguesa. São Paulo: Cultrix, 2006. 
PINHO, Wanderley. Salões e Damas do Segundo Reinado. São Paulo: Livraria Martins Fontes, 1942.

RIO, João do. A alma encantadora das ruas. Organização de Raúl Antelo. São Paulo: Companhia das Letras, 2008, p. 234-252.

SPIX, Johann Baptist von e MARTIUS, Carl Friedrich Philipp von. Viagem pelo Brasil:18171820, trad. Lúcia Furquim Lahmeyer. Belo Horizonte: Itatiaia ; São Paulo: EDUSP, 1981.3vTEIXEIRA, Múcio. Novos ideais. Rio de Janeiro: Tipografia Nacional,1880. Disponivel em https://www.literaturabrasileira.ufsc.br/documentos/?action=download\&id=43404\#_ft6 acesso 05.04.2018.

ZUMTHOR, Paul. Performance, recepção, leitura. Tradução de Jerusa P. Ferreira e Suely Fenerich. São Paulo: EDUC - Editora da PUC-SP, 2000.

Sítios eletrônicos

ACADEMIA BRASIL-EUROPA DE CIÊNCIA DA CULTURA E DA CIÊNCIA E

INSTITUTOS. INTEGRADOS DE PESQUISA.

Disponível em: http://www.revista.akademie-brasil-europa.org/CM09-02.htm.Acesso em 20/10/15.

INSTITUTO DE RADIODIFUSÃO EDUCATIVA DA BAHIA.Disponível em http://www.irdeb.ba.gov.br/educadora/catalogo/media/view/5924 acesso 26.08.15.

INTERNATIONAL MUSIC SCORE LIBRARY PROJECT. Disponível emhttp://imslp.org/wiki/Solos_for_Treble_Instrument,_Especially_Soprano_Recorder_\%28K imberling,_Clark\%29 acesso 01.11.15.

MÚSICA BRASILIS. Disponível em: < http://musicabrasilis.org.br/temas/modinha-entre-oerudito-e-o-popular>. Acesso em: 28 set. 2015.

MUSEU VILLA-LOBOS. Disponível em http://museuvillalobos.org.br/museuvil/index.htm acesso 02.11.15. 


\section{GLOSSÁRIO}

ARCADISMO Movimento literário que surgiu na Itália, inspirado no modo grego de uma região da Grécia Antiga, Arcádia, com finalidade de combater o barroco e difundir os ideais neoclássicos.

AUTOS

BARDO

BÁRDICA

CANÇONETA

CANTIGA

ELEGÍACOS

FARSA

LIED

MOTE

RAGA

ROMANCE

SAGA

SERRANILHA

SERRANILHA GALLEZIANA

Composição poética de origem espanhola também chamada Serrana ou cantiga serrana. em verso, que se originou na Idade Média. Em Portugal, foi muito presente na obra de Gil Vicente, no século XVI.

Poeta ou declamador. Geralmente utilizava lira ou harpa para acompanhar seus poemas épicos.

Que diz respeito ao bardo.

Pequena canção.

Poemas cantados.

Tristeza profunda.

Gênero específico da tradição Vicentina.

Música vocal cantada sobre poema estrófico em língua germânica.

Verso ou pequeno conjunto de versos sobre os quais os poetas glosavam as suas cantigas, também chamado moto ou cabeça.

É como são chamados os modos usados na música clássica indiana. Conjunto de normas que regem a construção de uma melodia.

Poesia cantada, narra um acontecimento. Trazido ao Brasil pelos portugueses.

Significa "o que se diz". Gênero de narrativa em prosa, são de caráter épico e podem ser em forma de canções.

SINCRETISMO Síntese proveniente do encontro de culturas distintas.

TIRANA

Composição de cunho popular e folclórico, em prosa e verso, que contam histórias cheias de imaginação, fantasias e aventuras. Trazida a Espanha, consistia numa dança cantada.

VILANCETE Composição poética do povo caracterizada por um terceto. 